\title{
Louis Couty e o império do Brasil \\ o problema da mão de obra e a constituição do povo no final do século XIX (1871-1891)
}

\author{
Moisés Stahl
}

\section{SciELO Books / SciELO Livros / SciELO Libros}

STAHL, M. Louis Couty e o império do Brasil: o problema da mão de obra e a constituição do povo no final do século XIX (1871-1891) [online]. São Bernardo do Campo, SP: Editora UFABC, 2016, 310 p. ISBN 978-85-68576-85-4. https://doi.org/10.7476/9788568576854.

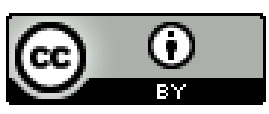

All the contents of this work, except where otherwise noted, is licensed under a Creative Commons Attribution 4.0 International license.

Todo o conteúdo deste trabalho, exceto quando houver ressalva, é publicado sob a licença Creative Commons Atribição 4.0.

Todo el contenido de esta obra, excepto donde se indique lo contrario, está bajo licencia de la licencia $\underline{\text { Creative }}$ Commons Reconocimento 4.0 . 
Lonis Contyeo Imperio do Brasil

o problema da mão de obra e a constituição
do povo no final do século XIX (1871-1891) 


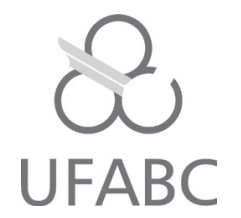

UNIVERSIDADE FEDERAL DO ABC

Prof. Dr. Klaus Werner Capelle - Reitor

Prof. Dr. Dácio Roberto Matheus - Vice-Reitor

\section{Editora da UFABC}

Profa. Dra. Adriana Capuano de Oliveira - Coordenação

Cleiton Fabiano Klechen

Natalia Gea 


\section{MOISÉS STAHL}

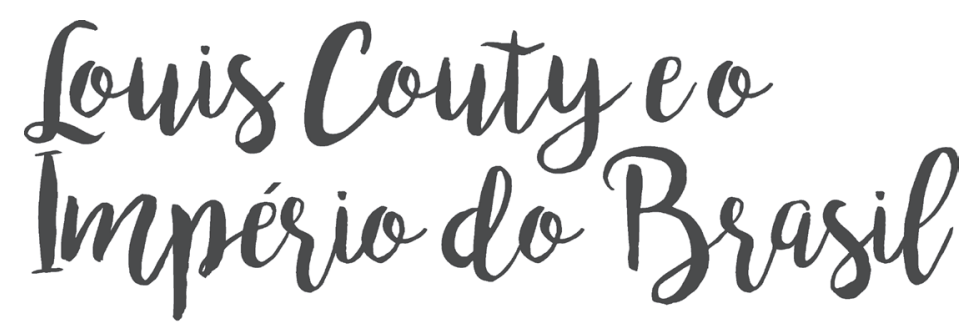

o problema da mão de obra e a constituição do povo no final do século XIX (1871-1891)

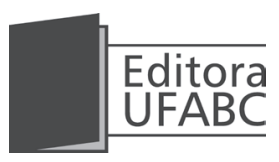

São Bernardo do Campo - SP 2016 
(- Copyright by Editora da Universidade Federal do ABC (EdUFABC)

Todos os direitos reservados.

\section{Revisão}

Bruna Longobucco

\section{Projeto gráfico e diagramação}

Rita Motta - Tribo da Ilha, sob coordenação da Gráfica e Editora Copiart.

\section{Imagens da capa}

Escravos carregando café; gravura de Jean-Baptiste Debret, 1826. Retrato de Louis Couty, Fonte: A Ilustração; ano 2, v. 2, n. 13, jul. 1885

\section{Impressão}

Gráfica e Editora Copiart

\section{Stahl, Moisés}

Louis Couty e o império do Brasil : o problema da mão de obra e a constituição do povo no final do século XIX (1871-1891) / Moisés Stahl — São Bernardo do Campo, SP : EdUFABC, 2016.

ix, 310 p. : il.

ISBN: 978-85-68576-55-7

1. Couty, Louis, 1854-1884. 2. Imigração. 3. Brasil Império. 4. Abolicionismo 5. Ciência no Império. 6. Mão-de-Obra - Brasil. I. Título. 


\section{Agradecimentos}

Caro leitor, este trabalho em forma de livro é resultado de uma pesquisa de mestrado em história realizada nas dependências da Universidade Federal de São Paulo, Campus de Guarulhos. Na oportunidade tive a grande honra de ter como orientadora a Professora Dr. ${ }^{a}$ Wilma Peres Costa, que com tamanha dedicação e generosidade orientou a pesquisa, tornando-se responsável por todos os acertos deste livro, os erros são meus.

No desenvolvimento e nas fases deste livro, tive contanto com pesquisadores de larga experiência que ofertaram seus conhecimentos para a boa condução deste trabalho. Tendo isso como referência, agradeço imensamente às Professoras Elide Rugai Bastos e Ana Maria Oda, pela leitura e importantes sugestões quando da participação do exame de qualificação e da banca de defesa da dissertação.

Agradeço aos professores da Universidade Federal de São Paulo, sobretudo aos professores com quem mantive contato mais próximo, como Jaime Rodrigues, Maria Rita Toledo, Marta Chagas de Carvalho, Marcia D' Alessio, Alessandra El Far e Lindomar Albuquerque.

Aos amigos da turma do mestrado em história da UNIFESP, agradeço a todos o carinho da recepção e amizade compartilhada. 
Das instituições que percorri para compor esta pesquisa, sou grato aos funcionários da Biblioteca Nacional, Museu Nacional do Rio de Janeiro, Arquivo da Casa Imperial de Petrópolis e aos funcionários da Biblioteca da EFLCH/Unifesp.

Agradeço também aos funcionários da Biblioteca Brasiliana Guita e José Mindlin da USP, sobretudo agradeço à bibliotecária Samanta Lessa, que gentilmente se prontificou a digitalizar e me enviar um livro importante desta pesquisa.

Agradeço aos Professores Claudinei Magno Magre Mendes e Paulo Cesar Gonçalves da UNESP de Assis que me auxiliaram na feitura do projeto que resultou na pesquisa e neste livro.

Dos amigos que ganhei nesse percurso de ingresso à UNIFESP, sou grato a Jéssika de Aquino Bezerra pelo convívio, pelas conversas e discussões sobre o nosso século XIX. Agradeço ao Gustavo Ferreira pelas conversas e discussões, pelos cafés, pelas viagens e congressos, junto com a Jéssika fez com que as viagens aos arquivos e bibliotecas do Rio de Janeiro fossem muito mais agradáveis.

Dos meus amigos que auxiliaram nas leituras e críticas deste trabalho e de partes dele, agradeço especialmente Felipe Yera Barchi, amigo de longa duração, pelas sugestões e críticas. Da mesma forma agradeço a Leonardo Dallacqua de Carvalho e Luis D’Arcadia.

Agradeço também à Bruna Demari e Silva e Luana Almeida pela amizade, encontros e discussões.

Agradeço aos meus familiares, meu pai Moacir, minha mãe Geralda, meu irmão Mateus e minha irmã Juliana que me apoiaram e me apoiam nessa caminhada.

Por fim, agradeço à CAPES que financiou a pesquisa e à Editora UFABC que publicou a pesquisa. 


\section{Prefácio}

Talvez uma das mais profundas marcas das elites brasileiras desde o século XIX seja a sua extrema sensibilidade para a imagem externa do país, especialmente aquela proveniente dos homens de saber. A história é longa e data da elevação da Colônia à categoria de Reino Unido, em 1815, quando a atração e a acolhida dos viajantes estrangeiros por D. João VI foi empreendida com fino apuro diplomático, tecendo relações com os principais parceiros econômicos e políticos da nova entidade política que então se estabelecia. Negociantes como Armitage, homens de ciência como os botânicos Spix e Martius e Saint-Hilaire visitaram o Brasil à convite da Coroa e sob seus auspícios, produziram imagens do país, de sua natureza exuberante e exótica e de sua sociedade original, onde uma cepa da realeza européia buscava estabelecer legitimidade política no plano internacional, governando sobre uma população onde os descendentes de europeus estavam em minoria frente um grande e variado contingente de etnias indígenas e uma vasta população de escravos, além dos mestiços de vários matizes.

Essas imagens, especielmente aquelas de natureza benévola, tiveram grande durabilidade ao longo do século, 
quase como se o Brasil retratado entre 1815 e 1822, no momento de seu nascimento como entidade política autônoma, ficasse cristalizado na longa vida da monarquia constitucional. Quando não foram benévolas, vale dizer, quando lançavam um olhar ácido sobre a sociedade escravista, os círculos letrados do Império empenhavam-se em silenciá-las ou relativizá-las, valendo-se dos órgãos da imprensa periódica e sobretudo do peso do Instituto Histórico e Geográfico, instituição fortemente imantada pela Coroa. As instituições monárquicas e a ordem constitucional, quase sempre prezadas pelos viajantes que continuaram a frequentar o Brasil durante o século XIX, serviam de contrapeso à profunda impregnação da escravidão em todas as dimensões da vida brasileira, para os olhares europeus a quem se atribuía o poder de definir se haveria lugar para o Brasil Imperial no concerto das nações. Se a relativa estabilidade política parecia dar uma resposta afirmativa a essa pergunta no contexto conservador que caracterizou a Europa até a década de 1830, outras foram as agendas dos viajantes europeus a partir de então, especialmente a partir de 1848, quando a abolição da escravidão nas colônias francesas fez com que o Brasil perdesse um importante anteparo contra as crescentes pressões inglesas pelo fim efetivo do tráfico de africanos e da própria escravidão.

Além disso, há que se considerar que, desde a publicação do relato de viagem de Alexis de Tocqueville à América do Norte (La Démocratie en Amérique - 18351840), a agenda dos viajantes europeus em relação ao continente americano passou a expressar com grande contundência, a força das grandes transformações que 
faziam do capitalismo um sistema mundial. No que tocava à relação entre a Europa e a América, ficava evidente que a primeira não mais via na segunda o seu passado (e o da humanidade) representado pela intensa curiosidade pelos usos e costumes dos homens que ela considerava “primitivos", mas o seu futuro - a expansão das forças do comércio e da indústria, o campo para o exercício da ciência e da técnica, o lugar de iniciativas e projetos.

O naturalista viajante, figura típica da primeira metade do século XIX, também vai perdendo o seu lugar para uma nova forma de mediador cultural, o cultivador das ciências aplicadas que é atraído para o novo mundo pelas suas possibilidades de desenvolvimento econômico e que demanda a acolhida de projetos de investigação visando a solução de problemas técnicos, a busca de novos produtos utilizáveis pela indústria e à expansão dos negócios nas várias partes do mundo.

No seu brinde de Ano Novo, na Sociedade de Geografia de Paris, no alvorecer de 1869, o economista Jules Duval saudava o nascimento de uma nova relação entre a ciência, a natureza e a política, através da geografia, da exploração (científica e econômica) do globo e da colonização.

Nós atingimos, senhores, um período da história em que a humanidade adquiriu uma noção precisa e firme de seu destino terrestre. Este destino [...] consiste no governo inteligente do planeta sobre o qual ela reina, na cúpula da hierarquia dos seres [...]. A Terra nos aparece agora sob cores menos sombrias que em outras épocas: ela é, para nós, o teatro de nossa atividade e o instrumento de nossa potência. [...] 
A realização desse destino, descrita como três atos de um grande drama, configura-se na exploração do planeta, no aproveitamento de seus recursos e na sua colonização. Se o primeiro ato é apanágio da geografia, essa ciência é agora vista como portadora dos "instrumentos da ciência" e da "bandeira da civilização". O aproveitamento dos recursos, obra da indústria e do comércio, é a segunda etapa da apropriação da terra, pela qual os homens empreendem a circulação das riquezas do planeta. Mas o ato principal do drama parece estar reservado à colonização.

Quando se aplica às terras cultiváveis, ele não tarda a se transformar na colonização, terceira etapa de sua carreira, obra própria da agricultura. Apenas a colonização consagra, com uma marca indelével, a passagem e a ação do homem. É ela que atrai e implanta as populações, fixa e multiplica as familias, que arma de coragem as novas gerações e as sociedades jovens e recompensa seus esforços, em proporção aos obstáculos que enfrenta. A colonização pede o concurso da ciência, que observa os climas e analisa os solos; da legislação, que protege as propriedades e as pessoas; da religião que esclarece as raças indígenas e fortalece as raças imigrantes [...] À Exploração, ao aproveitamento dos recursos e à Colonização integrais do Globo! $!^{1}$

\footnotetext{
1 Jules Duval, «Géographie et colonisation. - Un Toast par M. Jules Duval», in Nouvelles annales des voyages, de la géographie et de l.histoire ou Recueil des relations originales inédites, communiquées par des voyageurs français et étrangers...: avec des cartes et planches, gravées en taille-douce / publ. par MM. J. B. Eyriès et Malte-Brun [et à partir de 1826] de Larénaudière... [et al.] e Paris: Gide fils, [puis] A. Bertrand, 1869.T.1, p. 365-368
} 
O jovem cientista francês Louis Couty, médico de formação, mas explorador incansável dos mais diversos campos das ciências aplicadas, foi uma expressão desses tempos inquietos, tendo dedicado ao Brasil e aos temas brasileiros os últimos seis anos de sua vida breve e profícua, encerrada no Brasil, aos trinta anos em 1884. Instituidor de uma nova disciplina científica - a biologia industrial - seu principal campo de investigação (e aplicação de conhecimento) foi o desenvolvimento agrícola, para o qual considerou essencial o fim da escravidão e a imigração estrangeira. Seu lugar de fala foi, sobretudo, o do profissional da ciência, mas esse lugar ele não o encontrou pronto. A elaboração do espaço do cientista profissional, seu alargamento e defesa intransigente pontuam toda a carreira de Louis Couty no Brasil, nas diversas instituições em que trabalhou e, principalmente no Museu Nacional. Do estudo dos venenos ofídicos, à exploração comercial da erva mate e da carne seca, passando pela agricultura cafeeira, não houve tema que escapasse ao seu interesse, ligando-se sempre ao interesse pelos temas políticos e sociais, dentre eles o combate à escravidão e à propaganda em favor da imigração estrangeira. Mas sua legitimação se fez por que ele conseguiu instituir um lugar para si, como cientista profissional, nos círculos de poder e, ao mesmo tempo, desenvolver uma presença ativa, na imprensa, dos temas que lhe eram caros. Desse lugar, Louis Couty podia falar para os brasileiros e também falar sobre o Brasil aos estrangeiros, fazendo anteparo às ácidas críticas proferidas pelo abolicionismo francês diante da manutenção da instituição escravista no Brasil. 
O laborioso estudo que nos entrega Moises Stahl nos fala sobre este cientista na construção de sua carreira, do seu lugar de fala e da legitimidade que adquiriu como mediador do Brasil para seus conterrâneos franceses. Historiador que maneja as fontes de forma crítica e incansável, o autor evita cuidadosamente todas as tentadoras facilidades de definir Louis Couty de forma apriorística e reducionista, tão comum na associação linear de seu pensamento à célebre frase "Le Brésil n'a pas de peuple" feita frequentemente por estudiosos brasileiros que a usam como uma espécie de "boutade" que serve a múltiplos e às vezes inconfessáveis fins.

Desde o início de sua pesquisa, que tive a alegria de orientar, Moisés olhou para essa frase não como uma definição, ou um ponto de chegada, mas como um enigma a ser desvendado em todos os seus termos, procurando sobretudo compreender Couty em suas próprias palavras, em seu círculo de relações, em seus imensos e tediosos relatórios. Por esse caminho, reconstruindo a trajetória do cientista em busca do campo da ciência, foi possivel melhor avaliar o papel de Couty nas redes de sociabilidade que ele estabeleceu no Brasil e na circulação de ideias que conseguiu empreender entre o Velho e o Novo Mundo. Dessa forma, a frase ganha a feição de uma ferramenta heurística, um guia de leitura na construção desse cientista como pensador e como ativista no Brasil do final do século XIX, assim como da repercussão de suas ideias nas décadas subsequentes.

A associação enigmática entre raça e nação, vivida de forma tão angustiada pelas elites brasileiras do final do século XIX ganha, através desse estudo, uma 
inteligibilidade nova por que o passo a passo de sua construção como cientista/tribuno foi cinzelada por um historiador apaixonado pelo seu tema e pelo seu ofício.

Eu aprendi muito sobre disciplina, tenacidade e paixão pela História com Moisés, durante a orientação deste trabalho. Creio que o leitor também aprenderá muito com este livro.

Wilma Peres Costa

Universidade Federal de São Paulo, Unifesp. 


\section{Sumário}

\section{Introdução}

2 Louis Couty: lugares e saberes, textos e contextos.... 11

$2.1 \mathrm{Na}$ França ............................................... 18

2.2 No Rio de Janeiro, no Império .................... 23

2.3 Na Escola Politécnica do Rio de Janeiro, a cadeira de Biologia Industrial ...................... 33

2.4 No Museu Nacional do Rio de Janeiro.......... 37

2.5 Veneno curare ............................................ 40

2.6 "Uma nova época para a ciência no Brasil":

o Laboratório de Fisiologia Experimental .... 47

2.6.1 Os equipamentos e a biblioteca do laboratório .......................................... 55

2.6.2 Uma descoberta que colocou o Laboratório no centro do mundo ....... 57

2.7 O noli me tangere dos cientistas.................. 60

2.8 Querelas internas entre o diretor geral do Museu Nacional e o diretor do Laboratório de Fisiologia Experimental.......................... 62

2.9 Internacionalização do abolicionismo brasileiro: o debate entre Louis Couty e Victor Schoelcher sobre a Lei do Ventre Livre de $1871 \ldots \ldots \ldots . . .67$

$2.10 \mathrm{O}$ abolicionismo contra Couty ................... 83

2.11 "Meu laboratório" que "eu devo e eu sei a vossa Majestade" 


\section{Ciência em expansão: o percurso de Louis Couty}

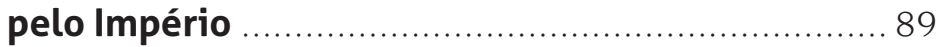

3.1 Ciência para aprimorar a produção ............ 94

3.2 Viagens ao Sul do Império: o mate, a carne seca e a busca de novos mercados .......... 100

3.3 Nos laboratórios, os produtos da nação .... 105

3.4 A propaganda dos produtos: uma missão para Couty .......................................... 108

3.5 O "café do pobre", a carne seca e o café ... 109 3.6 A máquina como solução ......................... 118

3.7 A Máquina de Secar Café Taunay-Telles, cultura técnico-científica e mediação cultural ........119

3.8 Apoteose da Máquina.......................... 128

3.9 O problema da moléstia do cafeeiro......... 130

3.10 O Plus Ultra do café............................. 148

3.11 A segunda expedição de Louis Couty pelo complexo cafeeiro do Rio de Janeiro e São Paulo

\section{4 "Sem atividade e necessidades, que ainda não são cidadãos úteis": do problema da mão de obra à constituição do povo}

4.1 O papel da Lei do Ventre Livre (1871) na formação do pensamento de Couty sobre o Brasil

4.2 O escravo e sua enxada

4.3 O domínio da máquina sobre a enxada .... 190

4.4 A inferioridade do trabalho escravo em sua longa duração 192

4.5 A "falta de homens livres ativos". 200

$4.6 \mathrm{O}$ imigrante europeu, o futuro 206 
4.7 "O lado futuro do passado": Ces Yankees du Brésil ...............................................2210

4.8 “'O Brasil não tem povo!'. É duro; mas é verdade" ............................................ 216

4.9 Apreender ideias, revelar projetos 229

\section{Apreender projetos, contrapor ideias: Louis}

5.1 Projetos e ações da Sociedade Central...... 250

5.2 As divergências entre a Sociedade Central de Imigração e a Sociedade Promotora de Imigração

5.3 Louis Couty e Sociedade Central: os termos da apropriação..................................... 256

5.4 O holandês Van Delden Laerne no Império.... 257 5.5 Louis Couty e Van Delden Laerne: dois destinos para o Império 263

5.6 Pequena propriedade e imigração europeia: a consolidação do pensamento de Louis Couty no programa da Sociedade Central de Imigração

5.7 A luta contra a imigração chinesa. 283

6 Considerações finais: Allons, c'est bien fini! 289

Fontes e Bibliografia 295 


\section{$\{1\}$}

\section{Introdução}

"Manejava Couty o bisturi de atilado experimentalista, e meditava nas mais sérias elucubrações do filósofo e do economista”. ${ }^{1}$

Louis Couty chegou e atuou em um momento intenso na história do Império do Brasil. Momento que compreende as décadas de 1870 e 1880, que se constituiu em palco de intensos debates sobre o destino do país. Com a década de 1870 ocorreu uma crescente diversificação dos interesses das elites, fenômeno que esteve ligado ao fato de que a transição do trabalho escravo para o trabalho livre teve diferentes dinâmicas e conteúdos regionais: a imigração em São Paulo, os engenhos centrais no Norte, as ferrovias em toda parte. A partir desse momento não era mais possível realizar políticas capazes de satisfazer interesses que se tornavam cada vez mais diferenciados. É a partir desta "heterogeneidade que se deve pensar a dinâmica complexa das críticas” ao regime monárquico ${ }^{2}$ que se estabeleceu com a década de 1870. Era

\footnotetext{
1 TAUNAY, Alfredo d'E. “Louis Couty, esboço biográfico”. In: COUTY, Louis. Pequena propriedade e imigração europeia. Rio de Janeiro: Imprensa Nacional, 1887, p. 13.

2 COSTA, Wilma Peres. "A questão fiscal na transformação republicana - continuidade e descontinuidade”. In: Revista Economia e Sociedade, Campinas, n. 10, p. 141-173, 1998. Para outra análise da relação entre as diferenças entre o norte o Império e as outras províncias Cf. Mello,
} 
o momento da Crise do Império. Nesse contexto, vários grupos sociais alijados pela política imperial adquiriram condições para expressar publicamente seus dissensos e projetos. ${ }^{3}$ Somados a isto, chegavam as "ideias novas", um bando delas, e com elas homens novos, como Louis Couty. Era o momento de Couty no Império. Para ele as ideias não eram novas, a novidade era o país, com sua imensa possibilidade aos olhos do jovem cientista.

Partia ele da Europa, da Paris do século XIX, de um ritmo acelerado próprio da modernidade dos Oitocentos. Nesse cenário, a paisagem era altamente desenvolvida, diferenciada e dinâmica, na qual tinha lugar a experiência moderna. Uma paisagem de:

Engenhos a vapor, fábricas automatizadas, ferrovias, amplas novas zonas industriais; proliferas cidades que crescem do dia para a noite, quase sempre com aterradoras consequências para o ser humano; jornais diários, telégrafos, telefones e outros instrumentos de media, que se comunicam em escala cada vez maior ${ }^{4}$

Chegava daquele cenário para o cenário brasileiro da Crise do Império, mas que ao mesmo tempo desencadeava um processo de transformação/modernização de suas instituições científicas e criação de novos lugares de

\footnotetext{
Evaldo Cabral de. O norte agrário e o Império (1871 1889). 2. ed. Rio de Janeiro: Topbooks, 1999.

3 ALONSO, Angela. "Crítica e contestação: o movimento reformista da geração 1870". Revista Brasileira de Ciências Sociais, v. 15, n. 44, p. 42, 2000.

4 BERMAN, Marshall. Tudo o que é sólido desmancha no ar: a aventura da modernidade. Tradução de Carlos Felipe Moisés; Ana Maria Ioriatti. São Paulo: Companhia das Letras, 2013, p. 28.
} 
ciência visando à constituição de uma ciência moderna no Império, ao mesmo tempo era a primavera da ciência e o outono do Império. Segundo Marshall Berman, o público moderno do século XIX vivia na sensação de estar em um mundo que não chega a ser moderno por inteiro, vivia numa "profunda dicotomia" de viver em dois mundos simultaneamente, "que emerge e desdobra a ideia de modernismo e modernização". ${ }^{5}$ Couty viveu esta dicotomia como poucos, da modernidade europeia às demandas de modernização no Brasil. Inseriu-se no contexto brasileiro como homem de ciência e morreu sendo aclamado como estudioso das questões da transformação do trabalho escravo e do imigrante, perfilhando afetos e desafetos: ávido de glória e pleno de amor pela ciência. ${ }^{6}$ Tencionava sempre, por em equilíbrio, dar solução aos antagonismos do seu tempo.

Louis Couty agiu em vários contextos do final dos Oitocentos no Brasil. Foi responsável pela introdução da fisiologia experimental no país; professor de uma disciplina nova, a Biologia Industrial na qual operou suas ideias num país novo. Escreveu livros sobre a escravidão, artigos sobre o café, relatórios sobre o mate, mediou conhecimento, defendeu ideias e o Imperador. Não era um viajante que narrava o Brasil para um público europeu, por exemplo. Seu olhar foi outro, foi o olhar do homem de ciência que via problemas e soluções. Ao ponto de ter querela com um compatriota, forjando-se assim o Couty

\footnotetext{
5 BERMAN, Marshall. Tudo o que é sólido desmancha no ar, op. cit., 2013, p. 26.

${ }^{6}$ Assim se referiu a Couty o Jornal do Agricultor, ano 4, tomo 7, n. 174,1882 .
} 
amigo do Brasil, como era chamado pela imprensa da época. Procedeu-se nesse trabalho examinar a movimentação de Couty em seu contexto ao mesmo tempo em que atuava, interagia e forjava o contexto. Desse modo, o esforço de análise de um perfil intelectual interessante como o de Couty, exigiu demonstrar sua atuação como agente ativo de seu momento. ${ }^{7}$

Constantemente citado pelos estudiosos da História e Ciências Sociais para compor uma análise ora da escravidão e de suas consequências, ${ }^{8}$ ora da imigração, ${ }^{9}$ da ciência ${ }^{10}$ e sua vulgarização; ${ }^{11}$ celebrizado pela expressiva

\footnotetext{
7 Sobre o tipo de biografia que procura examinar a atuação de um indivíduo em seu contexto, sendo a partir dessa ação perceptivel a modificação do contexto, ver: DOSSE, François. O desafio biográfico. Tradução de Gilson C. Cardoso de Souza. São Paulo: EDUSP, 2009.

${ }^{8}$ Cf. AZEVEDO, Celia M. Marinho de. Onda Negra, Medo Branco: o negro no imaginário das elites - século XIX. 3. ed. São Paulo: Annablume. 2008. SANTOS, Gislene Ap. dos. A Invenção do Ser Negro: um percurso das ideias que naturalizaram a inferioridade dos negros. São Paulo-Rio de Janeiro: Educ-Fapesp-Pallas, 2002.

9 Cf. Beiguelman, Paula. A Formação do Povo no Complexo Cafeeiro: aspectos Políticos. 2. ed. São Paulo: Biblioteca Pioneira de Ciências Sociais, 1978. MARTINS, José de Souza. O Cativeiro da Terra. 7. ed. São Paulo: Hucitec, 1998.

${ }^{10}$ Cf. GOMES, Ana Carolina Vimieiro. Uma ciência moderna e imperial: a fisiologia brasileira no final do século XIX (1880-1889). Belo Horizonte, MG: Fino traço; Campina Grande, PB: EDUEPB; Rio de Janeiro: FIOCRUZ, 2013. A historiografia que deteve maior atenção ao Museu Nacional tratou en passant do Laboratório de Fisiologia. Até o presente o trabalho de Ana Gomes foi o que tratou com mais acuidade da criação e ação do referido laboratório no contexto de formação e modernização da ciência no Brasil do século XIX, sobretudo a autora destacou a atuação de Louis Couty como mediador desse novo saber introduzido no Império.

${ }^{11}$ Cf. VERGARA, Moema de Rezende. Contexto e conceitos: história da ciência e "vulgarização cientifica" no Brasil do século XIX. In: Interciencia, v. 33, n. 5, 2008.
} 
frase: "O Brasil não tem povo", ${ }^{12}$ Louis Couty é nessa pesquisa privilegiado como objeto de estudo. Com efeito, visou-se analisar as ações e o pensamento de Louis Couty sobre dois temas: o problema da mão de obra e sua relação com o que chamamos de discussão sobre a constituição do povo no Império. Isto é, como se deu a transformação do trabalho escravo pelo trabalho livre para Couty? Como nas discussões sobre essa transformação o ideal de povo aparecia? Desse modo, vamos demonstrar como nessas discussões Louis Couty sedimentou em seu contexto, pelo viés científico, uma ideia de trabalhador europeu ativo capaz de substituir não apenas o trabalho do negro escravizado, mas também capaz de constituir um povo que seguiria o modelo europeu de civilização, tornando-se assim um porta-voz do imigrantismo, ideólogo do branqueamento.

Para analisar as fontes, os escritos - seus textos em jornais, relatórios científicos e livros - de Couty, para compreender e interpretar seu pensamento, bem como a construção desse pensamento, foi necessário indagar o texto procurando seguir uma exemplificação feita por Francisco Falcon a respeito da história do pensamento, ou ideias: “... as indagações se dirigem ao texto ou ao discurso, e também à mensagem, mas sempre de olho na intertextualidade e na contextualização". ${ }^{13}$

12 José Murilo de Carvalho analisou esta frase de Louis Couty para discutir o tema da cidadania. Cf. CARVALHO, José Murilo de. Os Bestializados: o Rio de Janeiro e a República que não foi. 3. ed. São Paulo: Cia. das Letras, 2006.

13 FALCON, Francisco. "História das Ideias". In: Domínios da História: Ensaios de teoria e metodologia. (Org.) CARDOSO, Ciro Flamarion; VAINFAS, Ronaldo. Rio de Janeiro: Campus, 1997, p. 95. Outra discussão 
Para John Pocock, o resgate das intenções que um autor teria ao elaborar seu texto, não se basta, sendo preciso ir além dela. Com efeito, observa Pocock que "quanto mais provas o historiador puder mobilizar na construção de suas hipóteses acerca das intensões do autor, que poderão ser aplicadas ao texto ou testadas em confronto com o mesmo, maiores serão as suas chances" de êxito. ${ }^{14}$ Desse modo, procedemos recorrendo às mais variadas fontes, sem atermos na memória laudatória que seus coevos construíram sobre Couty.

Seguimos uma direção metodológica que se relaciona com a história do político. Como propõe um de seus expoentes, Pierre Rosanvallon, o objetivo desta história é promover o entendimento de "como uma dada época, um país ou um grupo social tenta construir respostas para aquilo que, com maior ou menor precisão, elas percebem como um problema". ${ }^{15}$ Com efeito, dado a percepção do problema, a questão da mão de obra e do povo, objetivou demonstrar como Louis Couty, através de seus lugares, textos e redes de sociabilidade, atuou na tentativa de resolução desses problemas e como sua resolução proposta foi recebida e compartilhada na sociedade e assimilada nos projetos de modernização do país.

Como já nos referimos, o contexto de Louis Couty foi intenso, decisivo para o destino do Império. Ao mesmo

sobre esta ramificação da história pode ser conferida em: TUCK, Richard. História do Pensamento Político. In: BURKE, Peter. (Org.). A Escrita da História: novas perspectivas. Tradução de Magda Lopes. São Paulo: UNESP, 1992.

14 POCOCK, John. Linguagens do ideário político. São Paulo: Edusp. 2003, p. 27.

15 ROSAnVAllon, Pierre. Por uma história do político. São Paulo: Alameda, 2010, p. 44. 
tempo em que abria os horizontes para o país, com a modernização das instituições científicas, fechava, com o processo de abolição e as críticas aos modos de condução do regime, os horizontes do regime monárquico. Nesse tipo de contexto, segundo Pocock, "mais ricos e ambivalentes serão os atos de fala que ele [o autor] terá condições de emitir, e maior será a probabilidade de que esses atos atuem sobre o próprio contexto linguístico e induzam a modificações e transformações no interior dele". ${ }^{16}$

A natureza do trabalho que se propõe é o a reconstituição das relações do trabalho de um autor com seus contextos sociais, culturais e institucionais. Buscamos compreender as condições de emissão do pensamento de Louis Couty associadas a suas origens culturais, à rede de relações da qual foi mediador no Brasil e aos nichos institucionais em que aqui desenvolveu sua ação política. Desse modo, seguimos a exemplificação bem clara dos procedimentos que deve realizar o historiador das ideias/ pensamento feita por José D’assunção Barros. Diz ele que ao historiador das ideias cabe:

Perceber e dar a perceber a rede dentro da qual está inserido determinado autor 'produtor de ideias' - investigando dentro desta rede tanto as influências que o autor recebe como a recepção de suas ideias pelos seus diversos contemporâneos. Importante examinar, ainda, os diálogos do 'produtor de ideias' com toda uma rede intertextual que remonta à tradição dentro da qual seu pensamento se inscreve ou que, também de modo contrário, o contrasta com as tradições

16 POCOCK, John. Linguagens do ideário politico, op. cit., 2003, p. 28. 
contra as quais as ideias do autor estabelecem uma relação de ruptura. ${ }^{17}$

Com a Lei do Ventre Livre de 1871, estabelecia-se um fim para a escravidão, com isso recrudescia o debate sobre a mão de obra. A relação que Louis Couty estabeleceu com a Lei do Ventre Livre, fazendo da análise dessa lei ponto importante na sua visão da abolição e do destino do país, nos levou a definir o ano de 1871 como início do período analisado. O final do período que compreende a pesquisa encerra-se em 1891 com o fim da Sociedade Central de Imigração; organização que mais recorreu às ideias de Louis Couty para defender seus projetos e ações.

Para estudar um pensamento tão representativo de um momento, foi necessário adentrar nos territórios que Couty atuou, neste caso foi preciso adentrar no contexto de seus lugares, dos saberes, utilizando seus textos, os documentos internos das instituições onde atuou. Todavia, Couty foi além e ampliou sua ação quando entrou em debate sobre a Lei do Ventre Livre (1871) com uma autoridade francesa, desencadeando uma querela com os abolicionistas brasileiros. Desse modo, reconstruímos o contexto desse debate e como se deu a intervenção de suas ideias, formando assim o primeiro capítulo: Louis Couty, Lugares e Saberes, Textos e Contextos no Império do Brasil.

No segundo capítulo: Ciência em expansão: o percurso de Louis Couty pelo Império buscou-se evidenciar o

\footnotetext{
17 BARROS, José D’Assunção. "História das ideias - em torno de um domínio historiográfico”. Locus: Revista de história, Juiz de Fora, v. 13, n. 1, 2007, p. 208.
} 
seu percurso pelas regiões cafeeira das províncias do Rio de Janeiro e São Paulo, pelas regiões produtoras de mate e carne seca na região sul do Império. Nesse percurso demonstramos suas ações e os modos como se deu a intervenção do saber científico nas produções cafeeiras, do mate e do preparo da carne seca. Em decorrência desse movimento pelo território brasileiro, Couty publicou relatórios e artigos compondo, em conjunto com outras intervenções, o corpus documental da pesquisa. Nesse percurso veremos o Couty mediador de conhecimento a fim de aprimorar o aparato técnico da produção cafeeira.

Dado os lugares, os saberes, o contexto e o percurso, foi preciso trazer uma reflexão a fim de problematizar o pensamento de Louis Couty sobre o problema da mão de obra e da constituição do povo em seu contexto e demonstrar por quais meios ele elaborou suas teses, bem como se deu sua imediata recepção no ambiente dos que partilhavam de suas ideias e no ambiente dos que não partilhavam de suas ideias. Em seguida operamos a fim de apreender suas ideias em um todo estruturado e revelar projetos. Sendo este o assunto do terceiro capítulo: Sem atividade e necessidades, que ainda não são cidadãos úteis: do problema da mão de obra à constituição do povo.

Apreendida suas ideias e seus projetos, foi preciso problematizar sua recepção no grupo reformista da Sociedade Central de Imigração, que utilizou as ideias de Couty em suas ações para defender projetos e contrapor ideias, ao ponto de gerar uma confusão historiográfica que considerava Couty como membro da referida Sociedade. Confusão desfeita, temos o quarto capítulo: Apreender projetos, contrapor ideias: Louis Couty e a Sociedade Central de Imigração. 
O homem moderno do século XIX, sobretudo o homem de ciência como Louis Couty estava inserido em uma ordem dialética. Nessa ordem, tudo o que era criado seria destruído, visando a consolidação de um caminho para mais criação. ${ }^{18}$ Produção e consumo, demandando mais criação. Como veremos, Louis Couty era moderno:

Ser moderno é encontrar-se em um ambiente que promete aventura, poder, alegria, crescimento, autotransformação e transformação das coisas em redor - mas ao mesmo tempo ameaça destruir tudo o que temos, tudo o que sabemos, tudo o que somos. ${ }^{19}$

O motivo de analisar as ações e o pensamento de Louis Couty insere-se nas variedades das procedências dos elementos constitutivos do seu pensamento sobre o Brasil dos oitocentos: o olhar estrangeiro, o cientista, o publicista, os lugares institucionais de onde saía seu discurso, em suma, uma gama variada de procedências.

Dizia Louis Couty em 1884 após visitar e empreender pesquisas sobre o principal produto do país, o café: "logo me convenci que esses dois fatores sociais, o homem e o solo, tinham no Brasil uma importância inigualável; resumindo, o solo precisava do homem". ${ }^{20}$ Desse modo, vamos responder e problematizar porque para Couty o solo precisava do homem.

\footnotetext{
18 BERMAN, Marshall. Tudo o que é sólido desmancha no ar, op. cit., 2013, p. 62.

19 BERMAN, Marshall. Tudo o que é sólido desmancha no ar, op. cit. 2013, p. 24.

20 COUTY, Louis. “Introdução”. In: O Brasil em 1884, Esboços Sociológicos. Tradução de Ligia Vassalo, Senado Federal, Fundação Casa de Rui Barbosa - MEC. Brasília - Rio de Janeiro, 1984, p. 15. [grifo nosso]. Doravante, a cada citação do livro, O Brasil em 1884, optamos por citar o título e a data de cada artigo que compõe este livro.
} 


\section{$\{2\}$}

\section{Louis Couty: lugares e saberes, textos e contextos no Império do Brasil}

Estamos assistindo a um curioso movimento de opinião que merece ser assinalado em seu início e estudado mais tarde, tanto para o Brasil como para a Europa. Dos pontos mais opostos e sob as mais diferentes formas ecoa o mesmo chamado [...]. ${ }^{21}$

No trecho acima, Louis Couty assinalava o movimento de opinião, o debate sobre o futuro do país em torno da condução da abolição ou de como ela deveria ocorrer, decorrente da "crise que o Brasil" atravessava. Para tanto, cabia a um "único homem" a missão de solucionar a crise. Era do Imperador que o país inteiro esperava "a ruína ou a salvação”. Para auxiliar o Imperador na tarefa de conduzir esse momento, Couty listava quatro nomes: José do Patrocínio, um "polemista constantemente apaixonado”, que professava opiniões republicanas, mas que, segundo Couty, estava disposto em abandonar suas ideias se o imperador "ajudar-nos a fazer uma reforma

21 COUTY, Louis. "A missão de um homem". 25 nov. 1883. In: O Brasil em 1884: esboços sociológicos. Tradução de Ligia Vassalo. Rio de Janeiro: Fundação Casa de Rui Barbosa; Brasilia: Senado Federal, 1984, p. 257. Optamos por indicar a data da publicação de cada artigo citado a fim de que o leitor possa visualizar o percurso cronológico da intervenção das ideias de Louis Couty nos debates analisados. 
social mais indispensável que as reformas políticas: a libertação dos escravos". 22 No mesmo lado estava Joaquim Nabuco, "um orador que carrega dignamente um nome político estimado", que nos dizeres de Couty dava "ilustração" ao movimento abolicionista e também esperava de "uma única força" capaz de impor a transformação necessária do trabalho e da propriedade.

De outro lado, estavam "outros homens menos extremados" e em "nossa opinião mais meritórios" que observam "as necessidades do país no seu conjunto, sem subordinar tudo à solução imediata e primordial de um único problema”, o da abolição sem reformas. Esses dois homens também se voltavam para o Imperador. Um deles era o jornalista Ferreira de Araújo que "tão bem representa esse novo Brasil”. O Brasil tem necessidade de um homem, dizia Ferreira de Araújo citado por Couty, de um homem "pessoalmente honrado" como o Imperador, mas "tem necessidade, sobretudo, de um homem em toda a acepção da palavra”. Alfredo d'E. Taunay era o outro homem que "dirigindo-se ao Monarca já idoso, universalmente estimado, que deu ao Brasil longos anos de ordem, paz e certo sentido de liberdade e progresso", incitam-no a "tornar definitiva e durável a obra da pátria una, forte e poderosa" ${ }^{23}$

Nessa equação formulada por Louis Couty em 1883, sobre os destinos do Império, ao Imperador caberia

22 Foi assim que se referiu Couty ao que disse José do Patrocínio. COUTY, Louis. "A missão de um homem". 25 nov. 1883. In: O Brasil em 1884, op. cit. 1984 , p. 257.

23 COUTY, Louis. "A missão de um homem”. 25 nov. 1883. In: O Brasil em 1884, op. cit., 1984, p. 258. 
responder aos anseios dos diversos lados que compunham o "chamado" que ecoa e solucionar a crise e conduzir o país, pelas reformas necessárias, a uma nova etapa. Contudo, qual seria a missão de Couty na equação formulada? Os estrangeiros, dizia ele, "que assistem a tal espetáculo como observadores atentos e interessados têm o dever de dar testemunho". ${ }^{24}$ Apesar de não se referir a si, o trecho anterior revela o Couty que não quer "falar de política", ${ }^{25}$ mas que está atento aos acontecimentos e preza a continuidade do Monarca, sobretudo do Monarca que conduziu pessoalmente sua vinda para o Brasil. Todavia, sua relação próxima ao Imperador, acreditava Couty que "o homem pode modificar por si só a sua própria evolução e que a marcha de uma sociedade depende da associação livre dos esforços voluntários de seus diferentes membros, os que governam este país têm o dever de se separar tanto dos idealistas, partidários da libertação imediata, como dos políticos, para quem a abstenção é um meio de progresso". ${ }^{26}$ Portanto, meses depois de escrever sobre a missão do Imperador, indicou o que ele entendia ser a melhor ação na evolução dos fatos. Couty estava criticando o modo pelo qual o movimento abolicionista agia na defesa da abolição imediata ao mesmo tempo aconselhava o Imperador a seguir um lado, o das reformas via imigração, a melhor ação, segundo ele, na evolução dos fatos.

${ }^{24}$ COUTY, Louis. "A missão de um homem”. 25 nov. 1883. In: O Brasil em 1884, op. cit.. 1984, p. 258.

${ }^{25}$ COUTY, Louis. "A opinião a propósito das Coisas Politicas do Sr. Ferreira de Araújo”. 16 mar. 1884. In: O Brasil em 1884, op. cit., 1984, p. 242 .

26 COUTY, Louis. "Revolução, evolução, ação”. 17 abr. 1884. In: O Brasil em 1884, op. cit., 1984, p. 240-241. 
Em uma carta, de 1891, endereçada a Alfredo d'E. Taunay, D. Pedro de Alcantara, o então ex-Imperador, redigiu - o que ficou conhecido na imprensa da época como um "testamento político" do Império - suas memórias, onde relatou o que fez em seus anos de Brasil, o que pretendia ter feito, os projetos que animou o orgulho a partir dos resultados obtidos, creditando aos trabalhos realizados no Museu Nacional e a atuação de Couty considerações importantes.

[...] Sempre procurei animar palestras, sessões, conferências científicas e literárias, interessando-me muito pelo desenvolvimento do Museu Nacional. O que aí fez o Dr. Couty tornou esse estabelecimento conhecido na Europa; muitos dos trabalhos do Museu são hoje citados e aplaudidos [...]. ${ }^{27}$

O trecho da carta, acima transcrito, revela alguns significados da trajetória de Louis Couty no Império, sobretudo sua proximidade com o Imperador, fundada em um programa de desenvolvimento científico que era parte integrante do projeto modernizador do Império. Após o término da Guerra do Paraguai (1870) e da assinatura da Lei do Ventre Livre (1871), onde uma parte importante das elites econômicas e políticas via a concretização da emancipação escrava de forma lenta e gradual, ${ }^{28}$ a Coroa

27 Jornal do Commercio, 28 maio 1891. Esta carta de Pedro II foi publicada na imprensa da então capital da Republica e reproduzida nos jornais dos demais estados. [grifo nosso].

28 Ao mesmo tempo em que se iniciava esse processo de modernização, após a Guerra do Paraguai, abriu-se o fosso, fatal para o destino do Império, entre o Exército e as instituições políticas da monarquia. Em um sentido mais profundo, foi também a guerra que determinou 
engajou-se em um ativo trabalho de aprimoramento da imagem do país no exterior. O início de um programa de viagens do Imperador à Europa e a outras partes do mundo, ${ }^{29}$ a participação do país nas grandes exposições internacionais, a criação e desenvolvimento das instituições científicas, a organização dos Congressos Agrícolas que deveriam discutir os destinos da produção nacional, são evidências desse esforço modernizador. ${ }^{30}$ A centralização política colocava esse esforço em grande parte nas mãos da própria Coroa, que aparecia como anfitriã de viajantes e naturalistas, e em correspondência ativa com cientistas em várias partes do mundo. Podemos apreender essa centralização na correspondência entre Couty e Pedro II. Nessas correspondências, Couty informava suas

que o fim do trabalho escravo passasse a ser visto como "questão de Estado", estabelecendo a urgência de se dar início ao processo de emancipação. COSTA, Wilma Peres. A Espada de Dâmocles: o Exército, a Guerra do Paraguai e a Crise do Império. São Paulo: Hucitec/ Unicamp, 1996.

29 Era preciso estabelecer a imagem do Monarca cidadão e civilizado e repercutir isso mundo afora. SCHWARCZ, Lilia Moritz. As barbas do Imperador: D. Pedro II, um monarca nos trópicos. São Paulo: Companhia das Letras, 2013, p. 357.

30 A ideia de modernização e progresso, que surgia no contexto, estava baseada nos modelos europeu e americano, iluminando o pensamento da elite intelectual e política no Brasil. Era, portanto, a superação do trabalho escravo por um trabalho livre, condição fundamental para o desenvolvimento do país. A redefinição, nos oitocentos, das estratégias que recuperaram e impuseram a imagem do trabalho como propriedade a ser negociada livremente no mercado, tornou-se imagem engrandecedora do homem e meio para atingir a propriedade e ascensão social. Cristalizou-se, com isso, o progresso, confundido com o aumento da produção agrícola com a modernização técnica e com o trabalho livre operoso e disciplinado. MARSON, Isabel Andrade. "Trabalho livre e progresso". Revista Brasileira de História, São Paulo, n. 7, 1974. 
pesquisas e solicitava a intervenção pessoal do Monarca nas questões internas do Museu Nacional. ${ }^{31}$

Louis Couty teve uma inserção destacada no projeto de uma Ciência Nacional que se buscava realizar no país. Como iremos demonstrar neste capítulo, foi sua função como cientista que o levou a entrar em questões nacionais, na medida em que a ciência cumpria um papel de agente de transformação capaz de retirar o Brasil de uma condição de pré-civilizado e alçá-lo à condição de moderno e civilizado. A ciência nesse momento imprimia o meio capaz de modernizar e assim conduzir ao estágio mais elevado de civilização.

A memória de Louis Couty para seus contemporâneos era a de um homem ilustrado, que tinha no espírito a qualidade de defender os interesses do Brasil no exterior. Esta qualidade é recorrentemente reiterada, pela imprensa, ao longo de seus anos no Brasil, como exemplo a nota que saiu no Jornal do Recife sobre a iniciativa de Couty junto ao governo francês de ofertar o mate e a carne seca como alternativas alimentares ao exército da França, além de seus trabalhos realizados em prol da ciência brasileira o "Dr. L. Couty, sabemos todos, é um dos estrangeiros, dentre tantos que têm vindo a este país, que mais tem dado provas de se interessar vivamente pela nossa prosperidade". ${ }^{32}$

31 GOMES, Ana Carolina Vimieiro. Uma ciência moderna e imperial, op. cit., 2013, p. 79. Segundo Ana Gomes, essas cartas revelam também indícios da centralização da Monarquia brasileira nos assuntos do país. Para a autora, havia uma tensão entre o projeto de desenvolvimento de uma ciência nacional e os limites de um Estado monárquico e centralizador.

32 Jornal do Recife, 29 jun. 1881. Esta notícia saiu primeiro em a Gazeta de Notícias. 
Essa inserção de Couty, somada à memória que em carta o Imperador revelava ter dele, evidenciam que em seu tempo, Couty exerceu e usufruiu de uma representatividade significativa. Por isso, para compreenderemos suas ideias e como elas interviram nos conflitos ideológicos de seu tempo entendemos e reconhecemos a força das palavras como atos de intervenção. ${ }^{33}$ Destarte, não entendemos o pensamento de Couty como algo descolado dos problemas de seu momento, pelo contrário, suas ideias interviram nas questões mais importantes da última década do regime monárquico.

Uma inquietação que surge com isso, é saber como Louis Couty foi autorizado a discutir questões nacionais e propor soluções para os problemas de seu tempo. Para tanto, utilizamos a ideia de capital científico que consiste em um poder que se pode denominar temporal (ou político), "poder institucional e institucionalizado que está ligado à ocupação de posições importantes nas instituições científicas". ${ }^{34}$ Essa autoridade de falar sobre o Brasil, Louis Couty adquiriu no curtíssimo espaço de tempo que viveu no país (1879-1884), mas foi intensificada por sua relação com o Imperador e com o círculo de reformadores que lhe estava próximo e pelas posições importantes que ocupou, em um campo simbólico fortemente imantado pela Coroa, como o cargo de professor de Biologia Industrial na Escola Politécnica do Rio de Janeiro, sendo diretor do laboratório da mesma disciplina na mesma

33 SKINNER, Quentin: Hobbes e a liberdade republicana. Tradução de Modesto Florenzano. São Paulo: UNESP, 2010, p. 14-15.

34 BOURDIEU, Pierre. Os usos sociais da ciência: por uma sociologia clínica do campo científico. Tradução de Denice Barbara Catani. São Paulo: UNESP, 2004, p. 35. 
instituição; pesquisador associado do Museu Nacional e em seguida diretor do Laboratório de Fisiologia Experimental que estava anexo e devia obrigações administrativas ao Museu Nacional. A partir disso queremos caracterizar o capital científico de Couty, evidenciando as relações e posições que foi adquirindo e ocupando no período em que viveu no Brasil, se inserindo no projeto de constituição de uma ciência nacional, cujo escopo maior era modernizar o país e civilizá-lo. Para tal obra, era preciso recorrer aos lugares que poderiam fornecer homens (cientistas) com conhecimentos e capacidade de alcançar os objetivos pretendidos. Quem eram os cientistas que tinham a solução para transformar o país em moderno e civilizado? Como seria essa poção? Couty foi um deles, e sua atuação foi de destaque nesse processo de constituição e consolidação de uma ciência nacional e da propaganda de uma boa imagem do Brasil no exterior.

\subsection{Na França}

Louis Couty nasceu na cidade francesa de Nantiat, próximo a Limoges, em 13 de janeiro de 1854. De família pouco abastada, mas respeitável, ${ }^{35}$ realizou seus estudos secundários em Dorat, recebendo a carta de bacharel em letras em 1871, tendo 17 anos de idade. Em seguida formou-se em ciências e, "após brilhantíssimo concurso", conseguiu o lugar de assistente interno no hospital de

35 TAUNAY, Alfredo d'E.. "Louis Couty, esboço biográfico”. In: COUTY, Louis. Pequena propriedade e imigração europeia. Rio de Janeiro: Imprensa Nacional, 1887, p. 8-9. 
Limoges. Em 1873, empenhado na causa científica muda para Paris e se candidata a um cargo no Hospital, obtendo a aprovação. Em 1875 apresenta sua tese de doutoramento, sendo aprovada em três instituições: Faculdade de Medicina de Paris, Sociedade de Cirurgia e Academia de Medicina. "Que radiosa estréia de carreira" exclamou Alfredo d'E. Taunay. ${ }^{36}$

Numa carreira que seguia o célere desenvolvimento científico característico do século XIX, Couty se classificou em primeiro lugar para a função de professor na Faculdade de Medicina de Paris em 1878. Nesse entretempo, o Imperador D. Pedro II, conhecido entusiasta da ciência e das artes, procurava um professor para a nova disciplina de Biologia Industrial que seria criada na Escola Politécnica do Rio de Janeiro. A intermediação na contratação de Couty pode ser entendida nas correspondências entre D. Pedro II e o General francês Morin e complementadas na atuação do cientista francês Vulpian. Morin mantinha estreita amizade com Pedro II, sendo que em uma das correspondências entre ambos, visualizam-se detalhes do processo de escolha do futuro professor da Escola Politécnica. Dentre as exigências depreendidas, por D. Pedro II, estavam presentes a de ser jovem, bom conhecedor e seguidor dos modelos teóricos e práticas da ciência experimental europeia. ${ }^{37}$ Por sua vez, o fisiologista francês Vulpian, em carta com Pedro II, não escondia elogios às competências de Couty. ${ }^{38}$

\footnotetext{
36 TAUNAY, Alfredo d'E, op. cit., 1887.

37 GOMES, Ana Carolina Vimieiro, op. cit., 2013, p. 76.

38 GOMES, Ana Carolina Vimieiro, op. cit., 2013, p. 75. Para a autora, nesse processo de escolha de Couty como professor, Pedro II pode ser entendido como um mediador cultural e não apenas um mecenas.
} 
Ainda na França, Couty, já contratado, sob a incumbência do governo brasileiro, passou a realizar investigações experimentais sobre a composição da erva mate no laboratório de Vulpian. O Imperador acompanhava essas experiências de Couty que seriam apresentadas na Academia de Ciência de Paris. Ao mesmo tempo Couty cuidava da compra de equipamentos para a Escola Politécnica. ${ }^{39}$

O tema da erva mate ganhava relevância, tanto pelo interesse em diversificar a pauta de exportações brasileiras, como pela necessidade de estimular a economia da vasta fronteira platina, que recebia devida atenção desde o final da Guerra do Paraguai. Essas primeiras relações de Couty com o governo imperial eram noticiadas na imprensa da Corte ordinariamente, mas encontramos jornais que reproduziam as notícias sobre a ciência brasileira e sobre Couty nas demais províncias do Império. Como atesta a notícia veiculada na folha O Cruzeiro: "Escola Politécnica - O governo Imperial autorizou o nosso enviado extraordinário e ministro plenipotenciário em Paris a contratar o Dr. Luiz Couty, a fim de reger a cadeira de biologia industrial daquela escola". ${ }^{40} \mathrm{Na}$ província do Pará a nota da contratação de Couty saiu em um texto curto, como na acima citada, sendo bem provável uma reprodução de outro jornal da Corte. ${ }^{41} \mathrm{Na}$ Bahia o mesmo ocorreu no periódico O Monitor. ${ }^{42}$ Essas veiculações na imprensa da Corte e suas reproduções nas demais províncias do Império dão o tom do capital científico que

39 GOMES, Ana Carolina Vimieiro, op. cit., 2013, p. 77.

40 O Cruzeiro, 14 ago. 1878.

41 O Liberal do Pará, 6 set. 1878.

42 O Monitor, 20 ago. 1878. 
Couty possuía e que ganhava mais visibilidade e novos significados na realidade brasileira.

A presença de cientistas franceses já era importante na Escola Politécnica. Apesar de ter sido contratado para uma disciplina nova, Biologia Industrial, na Escola Politécnica, Louis Couty substituiu o cientista francês Dr. Clément Jobert. Para tanto, "foi rescindido o contrato com Jobert, contratando o governo imperial Couty". ${ }^{43}$ Com Couty no Brasil, a imprensa veiculou contendas entre Jobert e Couty. As controvérsias envolviam questões sobre a erva mate e os princípios tóxicos do curare extraido de plantas.

A primeira controvérsia, antes mesmo de Couty estar plenamente estabelecido, foi relatada numa carta que botânico J. Barbosa Rodrigues ${ }^{44}$ publicou no jornal Gazeta de Notícias. Nessa carta, que o redator do jornal denominou "Acerca da falsificação do mate recebemos a seguinte carta”, Barbosa Rodrigues procurou contrapor as ideias de Clément Jobert sobre o mate utilizado nas experiências de Couty em uma reunião na Sociedade de Biologia de Paris no início de 1879. Nessa reunião Jobert havia acusado o mate brasileiro de ser falsificado. Em oposição às observações de Jobert, Couty teria demonstrado que o mate tanto brasileiro quanto o paraguaio eram de boa qualidade, afirmou Barbosa Rodrigues. ${ }^{45}$

$\mathrm{Na}$ mesma nota de contratação de Couty foi informada a contratação do engenheiro Augusto Carlos da

43 Ministério do Império. Relatório apresentado a Assembleia Geral Legislativa na $2^{\text {a }}$ Sessão da $16^{\text {a }}$ Legislatura, 1877, p. 33.

${ }^{44}$ A respeito da vida e atuação de Barbosa Rodrigues, conferir um dossiê da Revista Brasileira de História da Ciência, v. 5, 2012.

45 Gazeta de Notícias, 13 mar. 1879. 
Silva Telles para o cargo de professor substituto para a cadeira de "artes e manufaturas" 46 da Escola Politécnica. Augusto Telles viria escrever alguns trabalhos sobre o café e maquinas de secar café, além de produzir máquinas de secar de café. Dentre os trabalhos escritos por Augusto Telles estão alguns em parceria com Couty e com Goffredo d' Escragnolle Taunay. Entre as criações com Goffredo Taunay esta a conhecida, na época, Máquina de Secar Café Taunay-Telles, que recebeu incentivo intelectual de Couty e algumas observações no periódico o Auxiliador. Os três participaram da comissão dirigida por Couty em 1881 que tinha como objetivo fazer propaganda dos produtos brasileiros na Europa. Dessa expedição resultou o Relatório que foi publicado em formato de livro: Propaganda na Europa do Mate, do Café e da Carne Seca. Além desses trabalhos, Augusto Telles publicou, em 1900, um livro com o título: O Café e o Estado de São Paulo.

Em carta a D. Pedro II, em que mencionava as motivações que contribuíram para sua decisão de aceitar a vir trabalhar e constituir carreira no Brasil, Couty conta os motivos que o fizeram deixar de lado o lugar de professor nas faculdades de medicina de Bordeaux ou Nancy, apontando a necessidade de conciliar seu futuro científco com os problemas financeiros de sua família, herdados com a morte de seu pai. ${ }^{47}$ Dizia ele a Pedro II, com a morte do pai "que eu me decidi, após maduras reflexões, de vir ao Brasil”. ${ }^{48}$ A menção indica a expectativa de uma

\footnotetext{
46 Ministério do Império. Relatório apresentado a Assembleia Geral Legislativa na $2^{\text {a }}$ Sessão da $16^{\text {a }}$ Legislatura, 1877, p. 32.

${ }^{47}$ GOMES, Ana Carolina Vimieiro, op. cit., 2013, p. 137.

48 Apud GOMES, Ana Carolina Vimieiro, op. cit., 2013, p. 137.
} 
carreira mais rápida para um jovem ambicioso e quiçá a de obter melhor remuneração no Império do que aquela que obteria na França, a partir do convite imperial. Não é possível aquilatar se ele foi atendido nessa expectativa, mas sua constante correspondência e encontros com D. Pedro II indicam que ele contava com o Imperador na proteção de sua carreira, inclusive em suas querelas com o diretor geral do Museu Nacional Ladislau Netto, onde Couty pedia a intervenção de D. Pedro II com o intuito de que houvesse um interesse do Imperador na autonomia do Laboratório de Fisiologia Experimental.

\subsection{No Rio de Janeiro, no Império}

Recebido com certa prevenção no Rio de Janeiro, atirou-se Louis Couty sem demora ao trabalho, e abriu logo assinalado lugar no seio da sociedade brasileira, fazendo-se notar pela facilidade da palavra e firmeza de conhecimentos. [...] fez repetidas conferências publicas sobre assuntos da sua especialidade; chamou a si a atenção dos mais abalizados e ilustres médicos do país, e, saindo do circulo que parecia prendê-lo pela natureza dos estudos tão árduos quanto exclusivistas e absorventes, não tardou a encarar de frente os problemas sociais do Brasil, que, pela sua complexidade e importância, lhe impressionaram mais fortemente o espirito, ávido de arcar com dificuldade correspondentes às valiosas forças de ação. ${ }^{49}$

Na Corte, logo no primeiro ano de Brasil, em 1879 , rapidamente se prestava as suas atividades de professor

${ }_{49}$ TAUNAY, Alfredo d'E, op. cit. 
e cientista, como que ávido em produzir urgentemente, sem tempo, dava-se em penhor para a ciência. Foi notável o rápido entrosamento que Louis Couty teve com as elites do Império. Como apontamos acima, mesmo antes de manter residência fixa no Brasil, somos levados a acreditar que Couty já era conhecido pelos homens de letras e de ciência da Corte. Isto porque, seu nome era recorrentemente citado na imprensa da Corte e das demais províncias. Uma vez que a maioria do público leitor desses jornais era membro da elite letrada do Império, Couty teve um amplo espaço de sociabilidade e constituiria uma rede de relações com figuras e instituições notórias da Corte.

Desse modo, a Sociedade Auxiliadora da Indústria Nacional (SAIN) através de seu periódico, o Auxiliador, propunha no dia primeiro de maio de 1879, o nome do professor Louis Couty para "sócio efetivo da Sociedade Auxiliadora da Indústria Nacional". ${ }^{50}$ A Sociedade Auxiliadora da Indústria Nacional, cujos membros, em sua maioria, eram parte integrante da elite política e letrada do Império, pensavam os modelos, alternativas, e soluções que viabilizassem a construção da nação e a promoção do progresso material, como também participavam direta e/ou indiretamente da política e do país. ${ }^{51}$

Um dos primeiros textos de Louis Couty com maior destaque nesse primeiro ano no Brasil foi publicado na

50 O Auxiliador, n. 5, 1879 , p. 13

51 ANDRADE, André Luiz Alípio. Variações sobre um tema: a Sociedade Auxiliadora da Indústria Nacional e o debate sobre o fim do tráfico de escravos (1845-1850). Dissertação (Mestrado em Economia) - Instituto de Economia da UNICAMP, Campinas, 2002. 
Revista Brazileira, periódico importante que atraía colaboradores que se tornaram notórios escritores e intelectuais como Machado de Assis e Sílvio Romero entre outros. ${ }^{52}$ Em seu artigo, Os estudos experimentais no Brasil, Couty tratou do papel da ciência na sociedade brasileira, lugar que era um imenso laboratório, com plantas pouco exploradas cientificamente. ${ }^{53}$ Couty lamenta o fato de toda essa "prodigiosa riqueza das terras, da excessiva vegetação e do próspero estado de certas lavouras” não serem "conhecidas e apreciadas" no continente europeu. Surpreendeu-se, também, com os "avultados rendimentos, que pode uma fazenda produzir"; de mais surpresa foi a expressão colocada diante do fato de que o país tem toda essa potência com uma mão de obra cara e rara, e questionava como deveria ser se "o trabalho escravo fosse substituido por menos antigo processos de lavoura

\footnotetext{
52 A Revista Brazileira constituiu-se em importante "vitrine" para literatos e homens de ciência do século XIX, formando o panorama da produção literária e cultural que procurava definir a identidade nacional. Teve quatro fases, de 1849 a 1855 temos a primeira fase em que a revista foi herdeira da Revista Guanabara, importante periódico do Romantismo brasileiro. Na segunda fase (1857-1861) a revista ficou conhecida como Revista Brazileira e em seu conteúdo predominavam os assuntos científicos. A terceira fase (1879-1881) tinha por finalidade, como observa Moema Vergara, proporcionar aos escritores brasileiros a publicação das produções literárias e científicas de reconhecido mérito e utilidade. O público-alvo da revista era o da elite letrada e econômica do Império. O próprio imperador era um leitor da revista sendo um financiador dela em 1880. Após o Império a revista teve outras fases. VERGARA, Moema. "Ciência e literatura: a Revista Brazileira como espaço de vulgarização científica”. In: Sociedade e Cultura, v. 7, n. 1, p. 75-88, jan./jun. 2004.

53 COUTY, Louis. "Os estudos experimentais no Brasil". In: Revista Brazileira, p. 216, 1879.
} 
[...]". ${ }^{54}$ A repercussão de seu artigo foi boa, como indica uma nota na imprensa que, ao se referir ao recebimento do mais recente número da Revista Brazileira, a Gazeta de Notícias, mencionava em destaque, fazendo distinção, o artigo de Couty sobre os estudos experimentais no Brasil. ${ }^{55}$ Nesse texto de maior circulação já esboçava preocupação e interesse pelas demandas da agricultura, em especial, o problema da mão de obra, ${ }^{56}$ que para ele se tornou objeto preponderante de entendimento e de transformação da sociedade brasileira. Com efeito, como aponta a historiografia, nesse texto Couty subsidiou argumentos pioneiros no tocante à vulgarização da ciência. ${ }^{57}$

Em meados do século XIX a finalidade do Estado e de seus intelectuais era elevar a natureza do país da barbárie à civilização. Naquele momento a política brasileira de construção nacional esteve condicionada à dominação e conquista do meio natural. ${ }^{58} \mathrm{Na}$ década de 1870 , depois da Guerra do Paraguai, depois da Lei do Ventre Livre (1871), o Império Brasileiro intensifica seu interesse

\footnotetext{
${ }^{54}$ COUTY, Louis, op. cit., 1879. p. 216.

55 Gazeta de Notícias, $1^{\circ}$ nov. 1879.

56 COUTY, Louis, op. cit., 1879, p. 216.

57 Moema de Rezende Vergara observa que esse é um dos textos emblemáticos da história da divulgação cientifica no Brasil. Nesse artigo, de acordo com Vergara, Couty defendia a necessidade de desenvolver uma ciência nacional para cuidar dos problemas do país, e sustentava a ideia de que, para obter apoio da sociedade para suas atividades, o cientista deveria comunicar os seus avanços para o público em geral. VERGARA, Moema de Rezende. "Contexto e conceitos: história da ciência e 'vulgarização científica' no Brasil do século XIX”. In: Interciencia, v. 33, n. 5, 2008.

58 DOMINGUES, Heloisa M. Bertol. "As ciências naturais e a construção da nação brasileira”. In: Revista de História; $2^{\circ}$ semestre, n. 135 , p. $41-60,1996$.
} 
em inserir-se no panorama internacional, trilhando um caminho que buscava a transformação do meio natural, de toda a riqueza catalogada, através da ciência - no âmbito de um projeto de ciência nacional - para o exterior, aos países civilizados em uma tentativa de receber a resposta de que o Brasil já estava em condição de civilidade igual à dos países da Europa. A fundação e modernização de estabelecimentos científicos num movimento de encontro às Exposições Universais, palco privilegiado da divulgação das imagens das nações, ocupariam posições estratégicas naquele momento. ${ }^{59}$ Desse modo, se no primeiro momento a preocupação dava-se em conhecer e se reconhecer, em um segundo momento as ações se davam em transformar, pela ciência, e ser reconhecido.

Para boa parcela das elites, o país se encontrava em estágio atrasado quando comparado ao grau de desenvolvimento dos países europeus. ${ }^{60}$ A ciência seria o agente transformador de uma sociedade atrasada para

\footnotetext{
59 As Exposições Universais eram palco internacional das grandezas dos países. Nelas buscava-se demonstrar o grau de desenvolvimento a qual pertencia determinado país. Eram, como assevera Barbuy, a "condensada representação material do projeto capitalista de mundo”. BARBUY, Heloisa. "O Brasil vai a Paris em 1889: um lugar na Exposição Universal”. Anais do Museu Paulista. São Paulo, n. 4, 1996, p. 211-261. A presença constante do Brasil nessas Exposições é dado revelador do esforço do Imperador e das elites da Corte de veicular uma imagem diversa daquela de país escravocrata atrasado, buscava-se representarumaimagem de nação moderna e cosmopolita. SCHWARCZ, Lilia Moritz. As barbas do Imperador, op. cit., p. 397.

${ }^{60}$ CARULA, Karoline. A tribuna da ciência: as conferências populares da Glória e as discussões do darwinismo na imprensa carioca (1873-1880). São Paulo: Annablume; Fapesp, 2009. p. 27. Ver também: GUALTIERI, Regina Cândido Ellero. Evolucionismo no Brasil: ciência e educação nos museus (1870-1915). São Paulo: Livraria da Física, 2008.
} 
uma sociedade ativa, progressiva, moderna. Não sendo apenas o pensamento das elites este, mas dos próprios cientistas que faziam ciência. Toda a apresentação de Couty a um público seleto como o da Revista Brazileira, as notas na imprensa sobre sua chegada, toda expectativa que sua ciência gerava é evidência dessa força de transformação que a ciência impunha no contexto, fomentando o caminho para o progresso.

Revelando uma agradável surpresa, Louis Couty encontrou "casualmente em todos os lugares" que percorreu "repetidas e variadas provas do grau de desenvolvimento intelectual e literário, administrativo, industrial e comercial" do país. ${ }^{61}$ Contudo, sentia falta de alguém que sintetizasse a grandeza científica, literária e produtiva do Brasil.

Atualmente as nações honram-se contemplando os seus sábios entre os seus mais uteis e ilustres filhos; e a França assim o entendeu, conferindo a $\mathrm{Cl}$. Bernard honras fúnebres que até então eram tributadas aos conquistadores e poderosos do século, de preferência aos que haviam adquirido direito à gratidão da pátria. ${ }^{62}$

Couty queria demonstrar que na Europa os cientistas passavam a ter status de heróis nacionais. Em um momento de definição das nações surgem com ela ícones que simbolizam sua grandeza. Era esta a reivindicação de Couty para o Brasil. Sentia ele falta de um símbolo, um ícone da ciência que resumisse o Brasil. Sobretudo, porquê:

${ }^{61}$ COUTY, Louis. "Os estudos experimentais no Brasil". In: Revista Brazileira, 1879, p. 216.

62 COUTY, Louis. “Os estudos experimentais no Brasil”, op. cit., 1879, p. 219 . 
No século XIX e principalmente no século XX não bastará a qualquer povo possuir grandes poetas, grandes escritores, grandes oradores, grandes administradores, não; será preciso que ele também possua investigadores pacientes e continuamente progressivos. $^{63}$

O século XIX indicou uma nova maneira de entender o mundo, "o meio natural e a sociedade passaram a ser compreendidos como ambientes em constante transformação e não domínios de permanência e previsibilidade". ${ }^{4}$ Ao cientista cabia tornar inteligível os meios técnicos e intelectuais de fomentar a transformação. Desse modo, Couty aponta nesse primeiro texto, que o espaço dado à ciência e aos cientistas na sociedade daquele momento vinha numa crescente e pode ser evidenciado pela presença constate das ideias dos cientistas nos periódicos e pelas discussões decorrentes que abrangiam variado tema. Por isso Couty trazia para si e para os seus essa responsabilidade icônica que fora atribuída a $\mathrm{Cl}$. Bernard na França. O homem de ciência resume a nação e a ele cabe a tarefa de transformar. Assim, se é a civilização que se busca, o caminho é a ciência, "se o Brasil deseja ativar o seu desenvolvimento intelectual, é de seu imediato interesse trilhar desassombradamente a senda das investigações cientificas". ${ }^{65}$

63 COUTY, Louis. “Os estudos experimentais no Brasil”, op. cit., 1879, p. 222-226.

${ }^{64}$ GUALTIERI, Regina Cândido Ellero. Evolucionismo no Brasil, op. cit., 2008, p. 11.

${ }^{65}$ COUTY, Louis. “Os estudos experimentais no Brasil”, op. cit., 1879 , p. 219. 
Se para atingir a civilização era preciso conhecimento científico, sua difusão na sociedade era essencial. ${ }^{66}$ Louis Couty entendia que a divulgação do conhecimento científico deveria estar na ordem do dia dos assuntos tratados pelos sábios e por homens instruídos. Dizia ele ser "preciso que o conhecimento dos métodos experimentais e dos problemas que por eles se resolvem faça parte da educação com o mesmo título que os demais conhecimentos" ${ }^{67}$ Como forma de alcançar esse ideal de vulgarização da ciência, Couty propõe uma série de estratégias de grande alcance para que a ciência chegasse ao grande público, sobretudo aos mais jovens. Os jovens, segundo ele, poderiam desasnar-se tornando leitores de Julio Verne, Hetzel e outros autores que poderiam incutir "nas mais tenras inteligências o gosto de saber indagar". ${ }^{8}$

Couty chegou num momento que a divulgação científica ganhava corpo no início da década de 1870 . Foram com as Conferências Populares da Glória os primeiros passos da intensa divulgação do fazer ciência. Essas conferências eram realizadas para demonstrar resultados e discutir temas sociais que o debate científco incorporou. As discussões decorrentes das conferências não se restringiram ao local de realização do ato, espraiavam-se pela imprensa da Corte. Este fato torna-se evidência da repercussão dos debates ocorridos nas Conferências e demonstra que o espaço havia adquirido uma

66 CARULA, Karoline, op. cit., 2009, p. 30-31.

67 COUTY, Louis. “Os estudos experimentais no Brasil”, op. cit., 1879, p. 233.

68 COUTY, Louis. “Os estudos experimentais no Brasil”, op. cit., 1879, p. 235-236. 
importância significativa, uma vez que, as pessoas que lá se apresentavam possuíam prestigio na sociedade. ${ }^{69}$ Essas conferências eram divulgadas na imprensa, informando hora, local e tema, como a seguinte nota: "O Sr. Dr. Luiz Couty encarregou-se da conferência n. 425, que há de ter lugar amanha, às 11 horas, no salão das escolas publicas da freguesia da Glória”. Nessa conferência Couty tratou de comparar as "moléstias mentais e das neuroses no Brasil e em França". ${ }^{70}$

Como asseverou o literato e político Alfredo d'E. Taunay, Couty "fez repetidas conferências públicas sobre assuntos da sua especialidade" e "chamou a si a atenção dos mais abalizados e ilustres médicos do país". ${ }^{71}$ Além das Conferências Populares da Glória, outro espaço de discussão do saber científico na Corte foi os cursos públicos do Museu Nacional. Os Cursos Públicos do Museu Nacional poderiam ser ministrados por seus membros correspondentes como Louis Couty que realizou tais cursos entre os anos de 1879 e 1881 , num total de $22 .^{72}$

69 CARULA, Karoline, op. cit., 2009, p. 30-31.

70 Gazeta de Notícias, 14 out. 1882. É interessante notar que essa conferência provocou reação do médico Souza Lima que enviou carta à Gazeta de Notícias expondo seus pontos contrários à conferência de Couty (16 out. 1882). Louis Couty esteve vinculado ao Hospício D. Pedro II por alguns meses, de outubro de 1881 a maio de 1882. Segundo informações da Gazeta de Notícias, O Dr. Gustavo Camera havia sido desligado do cargo de diretor do serviço médico do hospício, sendo Louis Couty e o Dr. Nuno de Andrade "nomeados facultativos clínicos" do estabelecimento (21 out. 1881). Permaneceu até maio de 1882 quando pediu demissão do hospício (6 maio 1882).

71 TAUNAY, Alfredo d'E. op. cit.

72 CARULA, Karoline. Darwinismo, raça e gênero: conferências e cursos públicos no Rio de Janeiro (1870-1889). São Paulo: Tese (Doutorado em História Social) - Departamento de História/FFLCH USP, 2012, p. 28-29. 
Os cursos públicos realizados no Museu Nacional mantinham certa frequência, tendo no público presente "pessoas de todas as classes da sociedade, honrando-os quase sempre Sua Majestade o Imperador com Sua Augusta Presença". ${ }^{73}$ Tais atos públicos se caracterizavam por serem espaços de sociabilidade letrada, sobretudo porque contavam com a presença de homens importantes da ciência e política. ${ }^{74}$ Nesses cursos Louis Couty e os demais cientistas do Museu Nacional divulgavam os resultados dos experimentos realizados. A imprensa cumpria a função de ampliar a reverberação do que se discutia nos cursos como fez a Gazeta de Noticias, que anunciava as primeiras preleções de Couty em 1879 a serem realizadas no salão dos cursos públicos do Museu Nacional. ${ }^{75}$

Diante dessa inserção, podemos notar que a Couty foi oferecido um amplo espaço social, cultural e político que lhe possibilitou contato com figuras de atuação significativa na vida pública do Império. O fato de ter sido ele indicado pelo seu professor da Faculdade de Medicina de Paris a partir da intervenção do imperador

\footnotetext{
73 NETTO, Ladislau. "Relatório Museu Nacional". In: Anexos ao Relatório Ministério da Agricultura. Apresentado à Assembleia Geral Legislativa $3^{\text {a }}$ sessão da $17^{\text {a }}$ Legislatura, 1879.

74 CARULA, Karoline, op. cit., 2012, p. 1-2. A temática abordada pelos oradores era vasta, abarcando política, economia, cultura e ciência. Carula analisa em sua tese as preleções que abordaram a temática científica, diz ela que: "A prática das conferencias públicas era um tipo de evento considerado moderno, uma vez que era semelhante às realizadas na Europa e nos Estados Unidos. Além disso, elas tratavam de temas considerados importantes dentro de projetos mais amplos de modernização da nação. Tais projetos refletiam a ânsia pelo moderno que marcou o século XIX [...]”, op. cit., p. 2.

75 Gazeta de Notícias, 17 out. 1879.
} 
D. Pedro II abriu, além de sua atuação de cientista, amplo espaço, garantindo a ele oportunidade de discutir as questões nacionais candentes do momento. Posto que, além dos temas científicos, discutiu em conferências e cursos, na Escola Politécnica, temas de ordem econômica e social: "Realiza-se hoje, Escola Politécnica, às 7 horas da noite, no anfiteatro de física uma conferência do Dr. Louis Couty, sobre os elementos nacionais do trabalho agricola" ${ }^{76}$ Temas que comporiam sua abordagem sobre a questão da mão de obra, como o tema da conferência de 1882: "Deve realizar-se hoje, na Escola Politécnica, às 7 horas da noite, no anfiteatro de física, uma conferência do Dr. Louis Couty sobre a Imigração europeia e a transformação das culturas atuais do Brasil". ${ }^{77}$ Com isso, as ideias de Louis Couty circulavam pelos quatro cantos da Corte.

\subsection{Na Escola Politécnica do Rio de Janeiro, a cadeira de Biologia Industrial}

A Escola Politécnica do Rio de Janeiro estabelecida em 1874 teve função importante no aparecimento da engenharia brasileira, sendo herdeira da Escola Central, criada em 1858 com o decreto $n^{\circ} 2116$, que por sua vez era subordinada ao Ministério da Guerra. A partir de 1874 , com as alterações que se seguiram com o decreto

\footnotetext{
76 Gazeta de Notícias, 5 jul. 1882.

77 Gazeta de Notícias, 12 jul. 1882. Nessa conferência esteve presente o Imperador. A Gazeta de Notícias faz um ligeiro comentário do ato e observa que "como sempre, o orador foi proficiente, tratando da tese anunciada, mostrou vastos conhecimentos sobre a matéria”, 13 jul. 1882.
} 
n ${ }^{\circ}$ 5600, a Escola Politécnica ficava sob a jurisdição do Ministério do Império ${ }^{78}$ Louis Couty veio contratado para o cargo de professor de Biologia Industrial na Escola Politécnica, curso até então novo que segundo o próprio Couty, "reúne num mesmo grupo a Agronomia, a Zootecnia e a Economia Política, pois trata ao mesmo tempo do solo, com seus produtos vegetais, e do homem, em seus esforços produtivos, musculares e intelectuais". ${ }^{79}$

A cadeira de Biologia Industrial assumida por Couty, tinha a disposição um laboratório, o Laboratório de Biologia Industrial, que chegou a possuir dois funcionários: um preparador e um servente. Além disso, possuía recursos de verba para experimentação. Tinha também coleções e uma biblioteca, além de "favores especiais do governo para viagens de instrução no interior do país" ${ }^{80}$ Essa nova disciplina foi caracterizada conceitualmente e exclusivamente por Louis Couty. Auxiliou em sua análise, sobretudo, instrumentalizou sua intervenção em questões de ordem social e política. A definição mais bem acabada da ideia de Biologia Industrial está no relatório Étude de biologie industrielle sur le café que Couty enviou ao diretor da Escola Politécnica. Na primeira parte deste relatório Couty analisa o aspecto biológico, geológico da produção do café, intervém na produção sugerindo a introdução de técnicas para melhorar a produção e qualidade do café. Mas será, sobretudo, na segunda parte que

\footnotetext{
78 COELHO, Edmundo Campos. As profissões imperiais: medicina, engenharia e advocacia no Rio de Janeiro (1822 - 1930). Rio de Janeiro: Record, 1999, p. 194-195.

79 COUTY, Louis. “Introdução”. In: O Brasil em 1884, op. cit., 1984, p. 15. [grifo nosso].

${ }^{80}$ Gazeta da Tarde, 8 out. 1884.
} 
Louis Couty elaborou uma chave interpretativa e operou as ideias em voga na Europa num lance a fim de analisar não apenas o solo, mas também o homem. Comparando a Biologia Industrial com a Economia Política e com a Sociologia, Couty observa que a Biologia Industrial "penetra mais no problema", posto que "estuda o esforço produtivo do homem, considerando-o em relação às suas diferentes necessidades". Com isto, esta ciência, "cria uma ligação estreita entre as ciências sociológicas e as ciências biológicas". 81

Desse modo, a Biologia Industrial entende uma mercadoria como "produto biológico" do solo e do clima, assim está mais próxima da botânica e da zoologia. Mas também entende a mercadoria como um "produto do homem”, resultante de seus cuidados e preparo. Dessa forma, "esta disciplina, de acordo com seu título, tem o dever de discutir o modo de utilização da mercadoria" e de ver em que medida uma indústria pode ser adaptada para a satisfação de uma necessidade. ${ }^{82}$ Para tencionar entender a produção cafeeira em sua totalidade, Couty forjou esta chave interpretativa que possibilitou ir além dos aspectos biológicos e geológicos da produção cafeeira.

Asseverava Couty que se o termo "biologia industrial tivesse o sentido que o programa atribuiu”, seu estudo terminaria após descrição e análise da produção

${ }^{81}$ COUTY, Louis. Étude de biologie industrielle sur le café, op. cit., rapport adressé à M. le directeur de l'Ecole Polytechnnique. Rio de Janeiro: Imprimerie du Messager du Brésil, 1883, p. 64. Todas as traduções do francês para o português foram de nossa autoria.

${ }^{82}$ COUTY, Louis. Étude de biologie industrielle sur le café, op. cit., 1883, p. 64 . 
cafeeira em seu aspecto biológico e consideraria a disciplina que a ele "foi confiada como uma simples dependência da agronomia, da zootecnia, da mecânica ou química agrícola" e assim não teria Couty ido além destes aspectos. Com efeito, ao aceitar "como propósito de excursão prática o estudo dos preços de custo do café e de suas diversas condições, a congregação da Escola Politécnica demonstra compreender em seu significado mais amplo este ensinamento que o Brasil tem a honra de inaugurar". ${ }^{33}$ Fica claro que Couty propôs um aspecto mais amplo de estudo que envolvia a análise da mercadoria em uma ampla dimensão de relações e chegou a considerar esse aspecto algo novo que o Brasil tinha a honra de inaugurar.

Esse saber novo que Couty construiu para entender a realidade brasileira, para ir além do solo e entender o homem em sua relação com o solo, foi o meio pelo qual ele elaborou uma análise sui generis da realidade brasileira do final do século XIX. No contexto ambíguo, antagônico, da realidade imperial, no cenário de projetos de modernização do país postos a prova, isto é, era preciso que os projetos fossem aceitos internamente para que fossem testados, reconhecidos, no estrangeiro, a obra de Couty com a Biologia Industrial pode ser entendida como síntese da instrumentalização da modernidade. Com essa obra conceitual, Couty poderia pôr em equilíbrio o que ele via como fora de ordem.

83 Idem, p. 63. 


\subsection{No Museu Nacional do Rio de Janeiro}

A década de 1870 marcou a modernização das instituições científicas do Império e o Museu Nacional passou por transformações importantes que fizeram dele um grande centro de pensar o país pela ciência. Eram mudanças inevitáveis, pois seriam a partir de uma nova caracterização das instituições científicas que as ideias novas seriam operadas, amalgamadas em uma nova realidade. Diante disso várias iniciativas foram realizadas. Com efeito, foi em 1876 que Ladislau de Souza Mello Netto assumiu a direção do Museu Nacional e realizou um processo de modernização interno visando contribuir para a modernização do Brasil. ${ }^{84}$

A gestão Ladislau Netto - de 1874 a 1893 - marcou a história do Museu Nacional. Enquanto Ladislau Netto foi diretor do museu, foram três os regulamentos estabelecidos sob seu comando, o de 1876, o de 1880 e 1890. O regulamento de 1876 destinava o Museu Nacional ao estudo da história natural, sobretudo do Brasil e ao ensino das ciências físicas e naturais e suas aplicações à agricultura, indústria e artes. ${ }^{85}$ Outro aspecto a ser destacado das reformas de 1876 se relaciona à criação da revista Archivos do Museu Nacional. Esse periódico era muito elogiado por Ladislau Netto que via nele meio pelo qual "pode ser aferido o progresso intelectual deste Império". Com o aparecimento dos Archivos do Museu Nacional, a

84 CARULA, Karoline. Darwinismo, raça e gênero, op. cit., 2012, p. 15.

85 LOPES, Maria Margaret. O Brasil descobre a pesquisa cientifica: os museus e as ciências naturais no século XIX. São Paulo: Aderaldo \& Rothschild; Brasilia: Unb, 2009, 159. 
instituição colheu inúmeras vantagens a partir de permutas entre o museu e instituições congêneres na Europa e Estados Unidos. Como resultado dessas permutas, o Museu ampliava seu acervo com "publicações importantíssimas, revistas e obras avulsas”, que para Ladislau Netto justificava o custeio da revista, posto que no "computo anual" o que o museu recebia era "superior ao do custeio dos Archivos". Além disso, pela vulgarização da revista os estrangeiros teriam conhecimento dos progressos e do "desenvolvimento científico a que tem atingido o Brasil". 86 A revista cumpriria uma função importante no desenvolvimento da ciência nacional, sua criação ocorreu em um contexto no qual estavam reservadas ao museu algumas missões que colaborariam no processo de modernização do país, tanto nos campos científico e cultural, como no campo econômico. ${ }^{87}$ No primeiro número da revista eram apresentados os membros correspondentes, sendo apenas três brasileiros num total de quarenta e quatro personalidades. Dentre os nomes estavam Paul Broca, Charles Darwin, Quatrefages, representando a adesão da publicação do Museu Nacional ao movimento científico internacional. ${ }^{88}$ Louis Couty não publicou nenhum artigo na revista Archivos do Museu Nacional.

\footnotetext{
86 NETTO, Ladislau. "Relatório Museu Nacional”. In: Anexos ao Relatório Ministério da Agricultura. Apresentado à Assembleia Geral Legislativa $3^{\text {a }}$ sessão da $17^{\text {a }}$ Legislatura, 1879.

87 GUALTIERI, Regina Cândido Ellero. Evolucionismo no Brasil, op. cit., 2008, p. 36.

88 SCHWARCZ, Lilia Moritz. O espetáculo das raças: cientistas, instituições e a questão racial no Brasil (1870-1930). São Paulo: Companhia das Letras, 1993, p. 71. As personalidades brasileiras arroladas como membros correspondentes da revista eram o Visconde de Bom Retiro, Thomas Coelho de Almeida e D. S. Ferreira Penna, op. cit., p. 71.
} 
Todas essas inovações da década de 1870 constituíam o nexo modernizador do país. Foi nesse cenário que Louis Couty tornou-se elemento importante no processo de transformação que atravessava o país em seu amplo aspecto: científico, econômico e político. Na ampla rede que interligou Brasil e Europa, Couty foi fundamental na conexão francesa onde procurou estabelecer pontes e revelou os meandros das ações dos homens de ciência na busca de novos mercados como demonstra um de seus coevos:

Aqueles que o viram [...] andando de ministério em ministério [francês], buscando o apoio de todos os homens que conheciam o Brasil, obtendo a nomeação de comissões incumbidas de julgar o valor nutritivo da carne seca, o papel benévolo do mate, empregado com bebidas nos países quentes, compreenderão como ele era dedicado ao país a que servia! $!^{89}$

Nesse contexto, a necessidade de criação de um laboratório de fisiologia possibilitaria aumentar os trabalhos experimentais realizados no Museu Nacional. Com feito, os trabalhos de fisiologia experimental eram realizados por Louis Couty e João Baptista de Lacerda e tinham em predomínio os que trataram das ações fisiológicas de substâncias tóxicas, como veneno de plantas e animais. Tais trabalhos, por exemplo, visavam testar as conclusões obtidas por Claude Bernard (1813-1878) que

89 “Biografia: L. Couty julgado pelo professor Gorceix”. In: Gazeta Médica da Bahia, série III; v. 2, p. 415, 1884-1885. 
realizava as experiências com as espécies europeias. ${ }^{90}$ Os experimentos sobre a ação fisiológica do curare era tema privilegiado do fisiologista francês Claude Bernard, que publicou seu Études physiologiques sur quelques poison americains: le curare. Neste estudo, Bernard destacava que os venenos eram instrumentos importantes de análise dos fenômenos da vida. Com efeito, o Museu Nacional e posteriormente o Laboratório de Fisiologia foram os centros principais de estudos sobre a ação fisiológica dos venenos de plantas e animais no Brasil. ${ }^{91}$

Existia um intercâmbio entre os pares da ciência da época, como é caso desses trabalhos sobre a fisiologia do veneno de plantas e animais. Os trabalhos de Claude Bernard sobre o veneno presente nas flechas dos indigenas eram o centro em que gravitavam os demais experimentos que objetivavam contestar ou ampliar os resultados.

\subsection{Veneno curare}

Em 1879, o diretor do Museu Nacional, Ladislau Netto, após viagens, trouxe cobras e plantas que seriam utilizadas em séries de experimentos realizados por Louis Couty e João Baptista de Lacerda. Foram vários os experimentos realizados e os resultados eram publicados nos periódicos franceses. Em muitos experimentos, a augusta presença do Imperador era veiculada pela imprensa como a que fez a público a folha $O$ Apostolo, quando noticiava

90 GUALTIERI, Regina, op. cit., 2008, p. 42-43.

91 GOMES, Ana Vimieiro, op. cit., 2013, p. 24-25. 
ter ido sua majestade Pedro II "assistir as experiências dos Drs. Couty e Lacerda Filho sobre a ação do Strychnos triplinervia e sobre o veneno da Brotops jararacussú".92 A presença do Imperador nessas experiências era frequente e servia para legitimar a ciência realizada. ${ }^{93}$

A trajetória das pesquisas e descobertas científicas sobre os venenos de plantas e de cobras, sobre erva mate, café etc. foi marcada por intensos debates num contínuo de fazer e refazer pesquisas construindo, assim, o contexto científico do final do século XIX. No momento de realização das investigações sobre o veneno de cobras e plantas, uma controvérsia, envolvendo de um lado Clément Jobert e do outro lado Louis Couty e João Baptista de Lacerda, fora publicada na seção "Notas Scientificas" da Gazeta de Notícias com o título: "O Sr. Dr. Jobert e os Drs. Couty e Lacerda”. Na nota o redator expõe a contenda entre Jobert e Couty sobre os resultados obtidos a partir de experimentos sobre o curare de plantas amazônicas. Jobert afirma que Couty e Lacerda se apropriaram dos resultados dele expondo-os como sendo dos dois, em oposição às acusações de Jobert, Couty e Lacerda redigem carta contestando os posicionamentos de Jobert. Esta carta também foi publicada na seção "Notas Scientificas" da Gazeta de Notícias. ${ }^{94}$

\footnotetext{
92 O Apostolo, 20 jul. 1879.

93 Com a década de 1870, D. Pedro II tornava-se um "monarca-cidadão", nos termos de Schwarcz, que consistia no fato de o Imperador inaugurar o hábito de passear pelas ruas, visitar colégios e ginásios, conversar com visitantes estrangeiros. Com este comportamento o monarca se aproximava de seus súditos. SCHWARCZ, Lilia Moritz. As barbas do Imperador, op. cit., p. 320-321.

94 Gazeta de Notícias, 14 nov. 1879.
} 
O veneno dos indígenas da América do Sul gerou curiosidade nos primeiros exploradores europeus que chegaram à região do vale do Amazonas e Orenoco nos século XVI e XVII. Desconhecido dos europeus, o veneno de ação paralisante, utilizado por algumas tribos indigenas nas pontas das flechas e dardos lançados pelas zarabatanas para a caça, era fabricado em um ritual conduzido pelo curandeiro da tribo. Os exploradores tencionavam saber qual espécie utilizada na mistura que compunha o veneno era responsável pela sua toxidade. Durante o século XIX, o interesse científico pelo curare se intensificou, sobretudo, após os relatos que dele fez Humboldt que, com Karl Friedrich Phlip von Martius e os irmãos Richard e Robert Schomburgk, atribuiram a toxidade do veneno às plantas do gênero Strychnos. ${ }^{95}$

$\mathrm{Na}$ década de 1870 naturalistas brasileiros procuraram determinar a composição botânica do curare. Em 1872, o botânico João Barbosa Rodrigues chegou à Amazônia, sob a incumbência do governo imperial, para fazer levantamento das espécies de palmeiras da região. Permaneceu na Amazônia por dois anos e meio, momento em que percorreu a região e colheu espécimes de plantas entrando em contanto com indígenas e aprendendo a

\footnotetext{
95 SÁ, Magali Romero. "Do veneno ao antidoto: Barbosa Rodrigues e os estudos e controvérsias científicas sobre o curare”. In: Revista Brasileira de História da Ciência, Rio de Janeiro, v. 5, suplemento, 2012, p. 13. Segundo Sá, pouco avanço ocorreu em relação à química do curare até em 1886 quando o químico alemão, Rudolf Boehm, isolou um alcaloide quaternário extremamente tóxico, que denominou tubocurarina, além de outros dois terciários fisiologicamente inativos. Desta forma, Boehm formulou uma classificação empírica sobre as variedades de curare, baseada, essencialmente, nos recipientes em que as mesmas estavam contidas, op. cit., p. 14.
} 
feitura do poderoso veneno. Após alguns anos do retorno de Barbosa, foram enviados, em 1878, ao vale do Amazonas os naturalistas viajantes do Museu Imperial, Carl August Wihelm Schwacke e Clément Jobert, com o objetivo de reunir coleção botânica para a instituição. Durante meses os naturalistas percorreram a região e colheram mais informações a respeito do curare, identificando as plantas principais que entravam na composição do veneno, denominadas pelos indígenas como "uirari" e "icu", identificadas por Schwacke como Strychnos castelneana e Anomospermum grandifolium Eichler. ${ }^{96}$

Nessa história do veneno curare, João Barbosa Rodrigues e João Baptista de Lacerda travaram intenso debate, como demostra Romero Sá, a fim de descobrir qual planta era tóxica e qual seu antídoto. Louis Couty entra na história quando realiza com Baptista de Lacerda alguns experimentos sobre o curare. Após ler um resumo de uma conferência de Couty feita no Museu Nacional, Barbosa Rodrigues intervém publicamente para questionar algumas observações na fala de Couty e envia carta a Gazeta de Notícias. Dizia ele que por ter sido

um dos primeiros que trataram cientificamente deste tóxico no Brasil: tendo estudado, no lugar em que ele se fabrica, tudo quanto com ele tem relação, não posso deixar, a bem da ciência, de fazer algumas observações sobre o resumo da conferência do ilustrado Sr. Dr. Couty. ${ }^{97}$

Interessante notar algumas características da fala de Barbosa que visam demonstrar legitimidade no que

96 SÁ, Magali Romero, op. cit., 2012, p. 14-15.

97 Gazeta de Notícias, 4 set. 1880. 
ele vai dizer, como por exemplo, o fato de ter ele in loco observado a preparação do curare entre os índios. Além disso, observar erros teria uma finalidade nobre, servia "a bem da ciência”. A finalidade de Barbosa em relação à preleção de Couty era demonstrar os erros que Couty teria emitido ao observar que os índios somente utilizavam o curare para a caça e "principalmente para pequenos animais". Barbosa questionava isso e dizia que os indigenas usavam o curare para além da caça, mas também em combates "principalmente quando estes são dados para obter prisioneiros". Couty asseverava que "as grandes flechas de arco" eram menos tóxicas do que se poderia supor. Sobre isso Barbosa notava que essas grandes flechas não era menos tóxicas, eram "completamente inofensivas pelo tóxico porque não há uma só tribo, quer brasileira, quer peruana que empregue o curare nas flechas de arco". Segundo Barbosa, as flechas envenenadas pelo curare são aquelas lançadas pelo sopro ou pela força do braço. Outro erro apontado por Barbosa era ao fato de Couty ter dito que nas coleções do Museu Nacional não havia "nenhuma arma de guerra envenenada". Para Barbosa havia sim e dizia ele sentir "profundamente que o Sr. Dr. Couty fosse mal informado a esse respeito, ou que não tivesse um individuo conhecedor dos objetos que o mesmo museu possui, que melhor o informasse". O museu possui muitas armas de guerra envenenadas, "estão todas no salão 9, nos armários 6, 13, 14 e 15 e nos quatro ângulos da grade do centro da mesma sala formando troféus, como se pode verificar, como a poucos dias verifiquei". ${ }^{98}$

98 Gazeta de Notícias, 4 set. 1880. 
Em resposta a essas observações e acusações Louis Couty não se pronunciou, mas João Baptista de Lacerda sim. A resposta de Lacerda foi imediata, de chofre, ele rebateu as acusações direcionadas à Couty, mas que no fundo também mirava em Lacerda, posto que Barbosa ao dizer que Couty era mal informado, de que não havia um "indivíduo conhecedor" capaz de informar Couty, poderia ter se referido a Lacerda. O fato é que um debate longo foi retomado. ${ }^{99}$

Sr. Redator, Colaborador do Dr. Couty em diversos trabalhos científicos, inclusive nos trabalhos muito recentes sobre o curare, compartilhando, portanto, a responsabilidade das opiniões por ele emitidas, quer nas conferencias do Museu, quer nos trabalhos já publicados na Europa, sou obrigado a dar uma resposta às arguições que lhe foram feitas em pequeno artigo publicado ontem no seu jornal. ${ }^{100}$

Lacerda não dirige os seus argumentos diretamente a Barbosa, o texto todo ele estabelece um diálogo com o redator do jornal e indiretamente posiciona-se contrário ao que disse Barbosa Rodrigues. Além disso, não menciona se Couty o autorizou a emitir resposta em seu nome. Para Lacerda o que havia dito Barbosa Rodrigues era uma posição que se conformava com o pensamento dos "antigos autores". Isto é, que o curare era muito empregado nas armas de guerra, e por isso "estranha que o Dr. Couty não adote essa opinião”. Lacerda utiliza o termo “antigos

99 Sobre o debate entre Barbosa Rodrigues e Baptista de Lacerda Cf. SÁ, Magali Romero, op. cit., 2012.

100 Gazeta de Notícias, 5 set. 1880. 
autores" e com isso, se coloca imediatamente na parte dos novos autores. Assim, as ideias de Barboza Rodrigues não estavam condizentes com o que tinha de mais avançado na matéria dos estudos do curare.

O Dr. Couty não contesta que o curare possa ser empregado na guerra o que ele afirma, baseado nas coleções do Museu, é que o curare é empregado principalmente nas armas de caça, insistindo no uso que fazem constantemente os índios da zarabatana, o que parece não ser muito conhecido dos autores europeus, e além disso, fazendo ver que muitas armas citadas por $\mathrm{Cl}$. Bernard como envenenadas não contêm veneno. ${ }^{101}$

João Baptista de Lacerda, por fim, pede que Barbosa Rodrigues examine melhor as vitrines onde estariam as armas de guerra dos índios antes de emitir qualquer parecer. O debate entre Barbosa Rodrigues e Louis Couty acabou sendo uma retomada de um debate mais antigo entre Barbosa e Lacerda. Os estudos sobre a ação fisiológica do curare foi tema caro à nascente fisiologia brasileira da década de 1870 e 1880. A grande questão por trás das investigações sobre o veneno de plantas e animais e sua ação no organismo, era saber se os efeitos tóxicos dos venenos das plantas e animais brasileiros eram semelhantes àqueles da Europa. ${ }^{102}$ Interessante destacar que os debates ganhavam forma através da publicação e veiculação na imprensa especializada ou não. É nesse momento de crescente pesquisa que será reivindicada a

101 Gazeta de Noticias, 5 set. 1880. [grifo do autor].

102 GOMES, Ana Vimieiro, op. cit., 2013, p. 26. 
criação de um laboratório específico para as pesquisas fisiológicas. ${ }^{103}$

\section{6 "Uma nova época para a ciência no Brasil": o Laboratório de Fisiologia Experimental}

O novo laboratório ocupa dois vastos salões do pavimento térreo do Museu, separados por uma grande arcada. O salão da frente é iluminado por duas janelas e uma porta que dão para o campo da Aclamação, o salão do fundo comunica com um pátio central do edifício. O primeiro, destinado especialmente às experiências e vivissecções, é todo ladrilhado de mosaico e tem ao lado esquerdo um gabinete para uso particular dos diretores. Aí fica a mesa das experiências, outra coberta de mármore para as autópsias, uma mesa para os trabalhos de microscópio, os armários para os aparelhos e instrumentos e uma pequena biblioteca. [...] No salão do fundo fica o aquário, dividido em dois compartimentos, servindo cada um deles para conservar as rãs e outros animais aquáticos e dispostos de modo a poderem ser iluminados pela projeção da luz do gás. Do outro lado um vasto tanque de lavagem forrado de chumbo e servindo por três torneiras; uma mesa coberta de azulejo correspondendo a diversos bicos de gás, destinada a preparações químicas,

103 GOMES, Ana Vimieiro, op. cit., 2013, p. 31. Segundo Ana Gomes, diante das limitações práticas encontradas no Museu Nacional para a realização de investigações fisiológicas, Louis Couty e João Baptista de Lacerda, "ao vislumbrarem as possibilidades de melhoria das suas pesquisas”, elaboraram um projeto e convenceram o Imperador e o Ministro da Agricultura dos benefícios de criação de um laboratório de fisiologia experimental para a ciência brasileira e para a divulgação dos produtos do Brasil no exterior. 
evaporação de extratos etc., um armário para reativos químicos, vidro e outros utensílios e uma estufa a gás. Em outro ângulo do salão deve ficar um alambique para as destilações da água e do álcool. ${ }^{104}$

Em detalhes era descrita as dependências do novo laboratório para o Império. Com "verdadeira satisfação" noticiava a Gazeta de Notícias a obra, revelando que o Laboratório de Fisiologia era "uma aspiração de há longo tempo manifestada pelas classes instruídas do país", sobretudo porque preenchia "uma lacuna assaz sensivel e lastimável no nosso sistema de ensino superior”. Enfatizava a folha que a inauguração do Laboratório de Fisiologia Experimental marcava "uma nova época para a ciência no Brasil". ${ }^{105}$

No processo de consolidação da ciência nacional, o Laboratório de Fisiologia Experimental anexo ao Museu Nacional deteve função importante em conjunto com as outras instituições que se modernizavam naquele momento. No século XIX a experimentação como modo de saber, diferente de um método baseado na observação, era relacionada a perspectivas analíticas de apreensão dos fenômenos naturais por meio da produção de situações não observáveis na jornada natural dos eventos da natureza. ${ }^{106}$ Com isso, o objetivo da fisiologia, entendida como campo de saber, era estudar as funções orgânicas em um corpo vivo. Nesse momento a medicina

104 Gazeta de Notícias, 2 abr. 1880.

105 Gazeta de Notícias, 2 abr. 1880.

106 GOMES, Ana Carolina Vimieiro, op. cit., 2013, p. 13. 
desvinculava-se da anatomia clássica e adquiria status de experimental: praticada, sobretudo, em um laboratório. ${ }^{107}$

O trabalho de convencimento da necessidade do laboratório foi processual. Em 1879, um ano antes da fundação do laboratório, Louis Couty procurava justificar a requisição do novo laboratório clamando pelos benefícios que teria. Dizia Couty que o laboratório "não será um gabinete de estudos simplesmente cientificos, senão uma oficina de experimentação, de observação e de rigoroso exame dos males que perseguem as plantas econômicas do país". ${ }^{108}$ Couty estava indo de encontro às atribuições que o Museu Nacional passou a ter quando de sua subordinação ao Ministério da Agricultura, Comércio e Obras Públicas em 1868. Era importante conciliar os interesses e ações da ciência com a produção agrícola do país. ${ }^{109}$ Além disso, é interessante notar que Couty em seu artigo na Revista Brazileira colocava ênfase em seu argumento prol a criação de laboratório, posto que "o Brasil possui importantes escolas", mas elas são "meramente pedagógicas ou de aplicação; não possuem dos laboratórios ou centros de experiência”, lugares onde o professor "pode não só provar e verificar o que ensina, mas ainda

107 Cf. GUALTIERI, Regina, op. cit., 2008. GOMES, Ana Carolina Vimieiro, op. cit., 2013. EDLER, Flávio. "O debate em torno da medicina experimental no segundo reinado”. História, Ciências, Saúde - Manguinhos, v. 3, n. 2, p. 284-299, jul./out. 1996.

108 "Ofício apresentando o relatório do Dr. L. Couty sobre o novo Laboratório de Fisiologia do Museu”. In: Livro de Correspondência Interna do Museu Nacional do Rio de Janeiro, 1879.

109 GUALTIERI, Regina, op. cit., 2008, p. 32. Ao Museu Nacional caberia, a partir de 1868, realizar atividades cientificas que visassem à melhoria da produção e qualidade do produto agrícola nacional. 
estender quanto possível os limites do ensino". ${ }^{110}$ Houve um trabalho de convencimento das necessidades de um laboratório como o de fisiologia. Podemos apreender disso que o Imperador Pedro II teria oferecido a Couty tal laboratório, mas que ele precisaria exercer um esforço de convencer os pares e o público da utilidade do Laboratório de Fisiologia. A legitimação do Laboratório de Fisiologia Experimental se daria com a interação de intenções científicas com interesses nacionais, ou seja, o interesse macro era aliar conhecimento científico na melhora e aperfeiçoamento dos produtos agrícolas. ${ }^{111}$

Uma análise do regimento interno do Laboratório de Fisiologia mostra algumas atribuições que deveriam ser cumpridas como a de "proporcionar todas as facilidades ao conhecimento e estudo de substâncias de utilidade real". Nesse sentido, a esfera de atuação do Laboratório compreenderia, de acordo com o Art. $2^{\circ}$, "não só o estudo das substâncias tóxicas medicamentosas ou alimentares, como todas as questões que interessarem a higiene, a patologia e a climatologia”. O escopo do Laboratório era amplo, englobando as necessidades do Império, mostrando-se, de acordo com o $4^{\circ}$ Art., a serviço da ciência nacional. Na composição do quadro de funcionários, Louis Couty era o diretor, Baptista de Lacerda o subdiretor e o Laboratório contaria com um preparador e dois praticantes. Além disso, contaria com uma biblioteca. Ao diretor e subdiretor caberia a função, também, de ministrar conferências públicas sobre "os assuntos de

110 COUTY, Louis. “Os estudos experimentais no Brasil”, op. cit., 1879, p. 217.

111 GOMES, Ana Carolina Vimieiro, op. cit., 2013, p. 35-36. 
mais interesse tratados no Laboratório". Sendo essas conferências anunciadas na imprensa e realizadas no edifício do Museu Nacional. O diretor ficava responsável pela apresentação anual de um relatório entregue ao Ministério da Agricultura. ${ }^{112}$

Tencionou naquele momento tornar relevante a ciência experimental e o ensino médico prático, em contraposição ao conhecimento especulativo e livresco, que segundo os defensores do método experimental, predominava no ambiente médico brasileiro. Nesse momento, uma "nova elite médica" mobilizou-se em defesa da reforma do ensino nas faculdades de medicina do Império. Essa defesa de reforma, fundamentada no modelo germânico, valorizava o modelo prático vinculado aos laboratórios. ${ }^{113}$ Foi em consonância com essas transformações que a fisiologia experimental adquiriu destaque para a ciência brasileira. Portanto foi nesse momento que se viabilizou a criação do Laboratório de Fisiologia Experimental do Museu Nacional, com incentivos financeiros do governo imperial e gerido pelo Ministério da Agricultura. ${ }^{114}$

O trânsito de cientistas de outras instituições era comum no Laboratório, além de ser o estabelecimento espaço público para tal finalidade como indica o Art. $4^{\circ}$ do regimento interno. Eram vários os "estudantes da Faculdade de Medicina do Rio de Janeiro" que "se utilizaram

112 Ministério da Agricultura. Relatório apresentado à Assembleia Geral Legislativa na $1^{\text {a }}$ Sessão a $18^{\text {a }}$ Legislatura, 1881.

113 GOMES, Ana Carolina Vimieiro, op. cit., 2013, p. 15. Para uma visão do debate, de uma guerra de discursos, entre os adeptos do método experimental com os adeptos da observação Cf. EDLER, Flavio Coelho, op. cit., 1996.

114 GOMES, Ana Carolina Vimieiro, op. cit., 2013, p. 15. 
dos aparelhos de que dispõe o Laboratório para estudar experimentalmente assuntos de suas teses". Ademais, era frequente também a visita de "vários médicos nacionais e estrangeiros, alguns dos quais acompanharam com interesse as experiências ali iniciadas". ${ }^{115}$ A atuação de Louis Couty foi fundamental nesse momento de introdução do saber fisiológico e consolidação da ciência nacional. Com efeito, é interessante notar que o saber fisiológico entrou em voga naquele momento e Couty era uma referência no assunto. Diante disso, especulou em 1881, já com o Laboratório de Fisiologia do Museu Nacional em funcionamento, o nome de Couty para dirigir também um laboratório similar na Faculdade de Medicina do Rio de Janeiro. No relatório enviado ao Ministério do Império, o diretor da Faculdade de Medicina, Conselheiro Vicente Candido Figueira de Saboia, solicitava a criação de um laboratório de fisiologia e a necessidade de contratar um cientista capaz de por em práticas os experimentos. Para tal necessidade o nome de Couty foi cogitado. ${ }^{116}$ Louis Couty teria apenas auxiliado na compra de equipamentos para esse novo laboratório de fisiologia experimental da Faculdade de Medicina. ${ }^{117}$ Contudo, como demonstra o relatório ministerial de 1883, publicado em 1884, a frequência dos estudantes da Faculdade de Medicina do Rio de Janeiro era grande no estabelecimento dirigido por Couty. Assim, tudo indica que naquele ínterim de anos o

115 Ministério da Agricultura. Relatório apresentado à Assembleia Geral na $4^{\text {a }}$ Sessão da $18^{\text {a }}$ Legislatura, 1883.

116 Ministério do Império. Relatório Apresentado à Assembleia Geral Legislativa. Rio de Janeiro: Typographia Nacional, 1882.

117 Gazeta de Notícias, 21 dez. 1881. 
desejado laboratório de fisiologia da Faculdade de Medicina não logrou êxito.

Os principais temas de pesquisa do Laboratório de Fisiologia do Museu Nacional atendiam a alguns interesses da medicina, da agricultura, do comércio e da economia nacional, ao mesmo tempo em que, ao seguirem os modelos europeus de ciência, contribuíam para a fisiologia da época. ${ }^{118} \mathrm{O}$ vínculo administrativo ao Ministério da Agricultura é sintomático da ação que se pretendia ter o Laboratório de Fisiologia. Por isso, eram solicitadas ao diretor Couty investigações sobre os produtos brasileiros e suas potencialidades fisiológicas e mercadológicas. A comissão científica de 1881, dirigida por Louis Couty, levou à Europa os resultados obtidos após várias expedições, empreendidas por Couty e sua comissão, nas regiões sul e sudeste do Império. O resultado dessas viagens científicas resultou no relatório de propaganda do mate, café e carne seca. ${ }^{119}$

Para além da aplicação prática dos resultados das pesquisas para variados setores da sociedade, podemos compreender nesse aspecto um movimento de legitimação para a criação do Laboratório de Fisiologia Experimental no Museu Nacional, quiçá o mais importante

118 GOMES, Ana Carolina Vimieiro, op. cit., 2013, p. 15. Nesse cenário o Laboratório de Fisiologia, através das atribuições e da ação dos cientistas que o compunha, construía sua relevância pretendendo-se indispensável para alguns setores da sociedade brasileira (Idem, p. 36). 119 As pesquisas realizadas e os resultados obtidos foram publicados em anexo no Relatório do Ministério da Agricultura de 1881. Logo em seguida o relatório fui publicado em formato de livro com o título: Propaganda na Europa do Mate, do Café e da Carne Seca. Por Dr. Luiz Couty e Engenheiros Luiz Goffredo de Escragnolle Taunay e Augusto Carlos da Silva Telles. 
para o governo imperial. Neste caso, "os recursos naturais brasileiros e, de certa forma, o Brasil, por meio da ciência, poder ganhar notoriedade na Europa, no círculo de países civilizados". ${ }^{120}$ Nessa dimensão de consolidação da ciência nacional, sendo a inserção do Laboratório, a atuação de Couty e de outros cientistas um aspecto desse processo, a ciência pode ser apreendida como um agente que ao operar a natureza bruta nacional, transformaria qualificando-as ao sabor do mercado europeu. O Brasil encontrava-se, no entendimento de Couty, em uma "fase de transição em que os estudos puramente teóricos e especulativos se tornam práticos e experimentais". A meta era "encurtar o mais possivel essa fase de transição" para que o país alcance o desenvolvimento que almejava. Estabelecidos os estudos experimentais com o laboratório, era o momento de resolver "tão numerosas e importantes questões, quase peculiares do Brasil, e, ao resolvê-las, constituir a ciência do Brasil". ${ }^{121}$ Por isso era importante e necessário "fundar laboratórios, centros de experiência largamente providos de todos os meios de pesquisa e de todos os instrumentos de investigação" para que o país ultrapassasse essa fase transitória na qual se encontrava. ${ }^{122}$ Com o laboratório, os problemas brasileiros seriam resolvidos por sábios brasileiros "ou aqui estabelecidos". Desse modo, não caberia tratar "os problemas brasileiros com conclusões deduzidas na Europa”. ${ }^{123}$ A originalidade

120 GOMES, Ana Carolina Vimieiro, op. cit., 2013, p. 37.

121 COUTY, Louis. “Os estudos experimentais no Brasil”, op. cit., 1879, p. 231 .

122 Idem, p. 231.

123 Idem, p. 228. 
da produção científica nacional estaria na transformação das qualidades naturais pelos métodos importados, obtendo assim resultados novos, originais. A vulgarização das coisas do Brasil, que são escassas na Europa, através de investigações científicas rigorosas, seria uma das formas de contemplar esse objetivo. ${ }^{124}$ Esse era o escopo que orientava as ações do governo imperial, não apenas dos cientistas, mas de todo um projeto de constituição de uma nação civilizada e moderna. A constituição do Laboratório de Fisiologia e as ações dos cientistas faziam parte de um escopo maior, havendo assim uma convergência de interesses, dos cientistas em ter seu lugar de ação e do governo em ter sua vontade atendida. Havia uma missão clara da ciência, mas é importante pensar a ciência não de modo uno, mas diversificado, na medida em que quem faz a ciência são os cientistas e as comunidades científicas com seus variados interesses e causas. Louis Couty atuou nesse contexto de forma ativa como demonstra o lastro documental de suas ações na ciência do império.

\subsubsection{Os equipamentos e a biblioteca do laboratório}

O Laboratório de Fisiologia de Couty requeria constantemente equipamentos para as atividades laboratoriais que Couty e sua equipe empreendiam. Nesse processo de compras de equipamentos notamos a dinâmica que o laboratório teve nos anos de Couty como diretor. Em junho de 1880 um ofício do Museu Nacional requeria

124 GOMES, Ana Carolina Vimieiro, op. cit., 2013, p. 38-39. 
"despacho livre na Alfandega da Corte para três caixas vindas de França pelo vapor 'Belgrano’”. A solicitação era para novos instrumentos do Laboratório de Fisiologia. Nas caixas encontrava-se a marca L. C. n. 2543,2544 e 2545, possivelmente as iniciais de Louis Couty. ${ }^{125}$

A lista de alguns equipamentos pode ser encontrada no relatório do diretor do Museu Nacional anexo ao relatório do Ministério da Agricultura do ano de 1881 . Nele constavam os seguintes instrumentos: escalpelos, tesouras e pinças, aparelhos registradores de Marey, aparelhos de respiração artificial, aparelhos elétricos e óticos, máquina para extração dos gases do sangue, frascos do sistema Pasteur para a cultura de micróbios, aparelhos para análise química da urina e para a análise espectral do sangue. Além de ter sido adquirida uma balança do sistema Bascule para pesagem rigorosa de animais. Havia sido encomendada também uma estufa de grandes dimensões e sendo esperado um motor de gás, de força de 2 cavalos, para mover aparelhos de respiração artificial, e um grande aparelho de resfriamento, destinado ao estudos das questões relativas ao clima. Com a chegada desses novos instrumentos seria possível compensar o Laboratório de Biologia Industrial, já que teria havido empréstimos e trocas entre os laboratórios. ${ }^{126} \mathrm{Um}$ ofício interno do Museu Nacional de setembro de 1881, recomendava que Louis Couty zelasse pela troca a fim de que

125 "Ofício requisitando despacho livre na Alfandega da Corte para três caixas vindas de França pelo vapor 'Belgrano'”. Livro de Correspondência Interna do Museu Nacional do Rio de Janeiro, 15 jun. 1880. 126 Ministério da Agricultura. Relatório apresentado a Assembleia Geral na $2^{\text {a }}$ Sessão da $18^{\text {a }}$ Legislatura. 1881, p. 63. 
o Museu Nacional fosse compensado caso o Laboratório de Fisiologia recebesse objeto de valor inferior. ${ }^{127}$

Louis Couty atuou tanto no Laboratório de Fisiologia Experimental, quanto no Laboratório de Biologia Industrial de modo que não podemos fazer uma diferenciação clara, por exemplo, se ele estava agindo em função do Laboratório de Biologia em determinada solicitação ou do Laboratório de Fisiologia. Isto é, nas missões para o Laboratório de Biologia Industrial colhia dados e para em seguida serem experimentados, por exemplo, no Laboratório de Fisiologia Experimental.

A biblioteca do Laboratório de Fisiologia Experimental é reveladora dos interesses de Louis Couty pela obra de Herbert Spencer (1820-1903). Sobretudo, porque entre os livros técnicos, destinados ao tema privilegiado do laboratório, encontravam obra de caráter geral, que abrangiam temas como desenvolvimento da indústria, sociologia, agricultura e fotografia. Entre os vários títulos, apareciam as obras de Spencer: Le première principes, Príncipes de biologie e Príncipes de sociologie, indicando a aproximação de Couty com as teorias evolutivas e ideais do social-darwinismo em voga no período. ${ }^{128}$

\subsubsection{Uma descoberta que colocou o Laboratório no centro do mundo}

Continuou só [João Baptista de Lacerda] as investigações sobre o veneno ofídico que haviamos

\footnotetext{
127 "Ofício sobre troca de aparelhos e instrumentos dos Laboratórios de Biologia Industrial da Escola Politécnica e Fisiologia deste Museu”. Livro de Correspondência Interna do Museu Nacional do Rio de Janeiro. 13 set. 1881 .

128 GOMES, Ana Carolina Vimieiro, op. cit., 2013, p. 49.
} 
começado juntos. Em sua opinião, o veneno das cobras é um líquido digestivo análogo ao suco pancreático e pode ser neutralizado por um agente químico: o permanganato de potássio. ${ }^{129}$

No trecho acima Louis Couty indica a descoberta que Baptista de Lacerda realizou nas dependências do Laboratório de Fisiologia. Descoberta que na memória de Lacerda foi o ponto alto do Laboratório. Dizia Lacerda que do Laboratório de Fisiologia Experimental saíram trabalhos importantes para a Academia das Ciências de Paris, memórias de valor para revistas e jornais estrangeiros e uma descoberta, que fez convergir para o Brasil a atenção do mundo civilizado. ${ }^{130} \mathrm{~A}$ descoberta que chamou atenção do mundo civilizado foi a ação do permanganato de potássio sobre o veneno das picadas de cobra, que se pretendia ser a solução para o mal. De fato a repercussão do antídoto contra picadas de cobra foi grande e o entusiasmo com a descoberta pode ser resumindo no que disse Ladislau Netto:

Cabe lugar de honra, entre as investigações científicas, ao notável descobrimento feito pelo Dr. João Baptista de Lacerda, subdiretor da $1^{\text {a }}$ seção e do Laboratório de Fisiologia Experimental anexo a este Museu. Refiro-me ao único antídoto até hoje conhecido para a peçonha das cobras venenosas. Este antídoto é o permanganato de potássio, não o achou casual ou empiricamente o Dr. Lacerda:

129 COUTY, Louis. "Laboratorio de Physiologia Experimental”. In: Anexos. Ministério da Agricultura. 1882, s/p. [grifo nosso].

130 Citado por: GUALTIERI, Regina, op. cit., 2008, p. 43. 
descobriu-o por meio de trabalhos reiterados e esclarecidos pelas mais detidas observações. [...] $]^{131}$

Para testar a descoberta foram realizadas:

Numerosas experiências repetidas no Museu perante centenas de profissionais, e desde então verificadas por toda a parte em que os casos se apresentam a reclamar o providencial antídoto; a imprensa nacional e estrangeira a preconizar o admirável descobrimento e a ciência inteira a aplaudir o autor que a humanidade dentro em pouco cobrirá de bênçãos, eis o que está no domínio público e o que o Governo Imperial na sua alta sabedoria deve mostrar que conhece e aprecia no devido valor, galardoando aquele benemérito brasileiro, a quem galardoam já os aplausos do universo. ${ }^{132}$

No calor da descoberta, sob o conselho do Imperador, Lacerda redigiu uma nota sobre seus resultados, sendo esta apresentada à Academia de Ciência de Paris por Quatrefages. ${ }^{133}$ A repercussão da descoberta nos quatro cantos do Império também foi grande. Afinal, a cura da peçonha de cobras era a solução para um mal que assolava todas as partes do mundo. ${ }^{134}$

\footnotetext{
131 NETTO, Ladislau. "Relatório do Museu Nacional". In: Anexos ao Relatório do Ministério da Agricultura. Apresentado à Assembleia Geral Legislativa na $1^{\text {a }}$ Sessão da $18^{\text {a }}$ Legislatura, 1881.

132 NETTO, Ladislau, op. cit., 1881.

133 GUALTIERI, Regina, op. cit., 2008, p. 43

134 GOMES, Ana Carolina Vimieiro, op. cit., 2013, p. 109-111. Segundo Gomes, o entusiasmo com a descoberta foi ainda maior diante da notícia de que o governo de Bombaim na Índia havia reservado uma premiação, de 100 mil libras, àquele que descobrisse um antidoto eficaz contra a picada de cobras (Idem, p. 110).
} 
Como sublinhamos no trecho que Couty relata a descoberta, as investigações científicas contra a peçonha de cobras teve em seu início a parceria entre Couty e Lacerda. Ausente no momento da apresentação da descoberta, sobretudo ausente na publicação e divulgação da descoberta, Couty fez realizar uma contraprova publicada na França que questionava a eficácia do permanganato de potássio como antídoto. Os resultados de Lacerda haviam sido publicados na França por intermédio do médico francês Jean Louis Armand de Quatrefages. Em seguida, a comunicação foi refutada pelo fisiologista francês Alfred Vulpian e por Couty. Com essa reação de Couty, fez surgir uma cisão entre ele e Lacerda. ${ }^{135}$

\subsection{0 noli me tangere dos cientistas}

A cisão entre Couty e Lacerda, decorrente do que teria sido o ápice da fisiologia brasileira no século XIX, continuou em debate até 1884 ganhando com força as páginas dos jornais. Em carta, Lacerda rebatia um suposto artigo de Couty, posto que dizia ele: "Ignoro se é da lavra do Sr. Dr. L. Couty o artigo publicado na Revue Commercialle, Financière et Maritime". Mesmo sem saber se era ou não Couty, "se não é, nada tenho que responder;

135 GOMES, Ana Carolina Vimieiro, op. cit., 2013, p. 115-116. Segundo Gomes, a imprensa criticou a postura de Couty por ter mostrado discordância na Academia de Ciências de Paris. Como resposta Couty disse ter se posicionado contrários aos resultados para defender sua "dignidade e créditos de experimentador". Em resposta, Lacerda, considerou Couty com um "ex-colaborador", posto que questões de personalidade afrouxaram o relacionamento (Idem, p. 116). 
se é, que se apresente o Sr. Dr. L. Couty de viseira erguida, porque desejo muito analisar os relevantes serviços prestados por este senhor ao Brasil”. ${ }^{136}$

No correr do texto o debate acerca da descoberta do antídoto da peçonha de cobras é reativado e Lacerda classificou o comportamento de Couty de "desleal". No final do artigo Lacerda refere-se à entrada de Couty no Brasil como sendo feita "por um caminho torto", mas não revela qual esse caminho. ${ }^{137}$

Um artigo na Gazeta de Notícias que tratava de assuntos da ciência comentou a contenda envolvendo Couty e Lacerda. Dizia o texto que em boa hora se descobria o bacilo da cólera, porém "um fermento diverso" estava desenvolvendo na classe médica brasileira. Esse fermento era a guerra entre Couty e Lacerda que ganhava as páginas dos jornais “de maior circulação” do Império.

Agora, é o Dr. Lacerda que investe furioso contra o Dr. Couty, e o motivo da rixa prevê-se: é o permanganato de potássio, que afinal de contas, se está considerando uma neutralizante [sic] reconhecidamente útil contra a peçonha das cobras, e quem sabe se contra alguma dentada humana, é por outro lado o noli me tangere do distinto experimentador brasileiro. ${ }^{138}$

Esse momento das discussões entre os cientistas marcou o declínio na época da fisiologia experimental como atesta a historiografia do assunto, sobretudo porque

\footnotetext{
136 Gazeta de Noticias, 21 ago. 1884

137 Idem.

138 Gazeta de Noticias, 15 out. 1884.
} 
meses depois desse debate Couty faleceria e Lacerda partiria para novos experimentos envolvendo a microbiologia, que ganhava repercussão dos estudos de Louis Pasteur sobre fermentos e a teoria microbiana. ${ }^{139}$

\subsection{Querelas internas entre o diretor geral do Museu Nacional e o diretor do Laboratório de Fisiologia Experimental}

Os investigadores da ciência deverão ter toda a liberdade de ação e iniciativa, que eles não sejam contrariados "em seus programas de ensino, nem nos planos de experiência, na a fortiori na direção intima dos laboratórios, por meio de regulamentos ou de fiscalizações tão nocivas neste caso, quanto algumas vezes são úteis no ensino dogmático" [sic]. ${ }^{140}$ Sublinhamos a importância do primeiro artigo de Couty na Revista Brazileira, nele, como notamos acima, Couty expõe o que ele entende como deve ser a ação do homem de ciência, sem fiscalizações "nocivas" que poderiam atrasar pesquisas e resultados. A única fiscalização verdadeira em seu entendimento seria exercida pelo "público ilustrado”. Esse público melhor que ninguém "saberá distinguir o verdadeiro do falso, a

139 GOMES, Ana Carolina Vimieiro, op. cit., 2013, p. 120-122. Ana Gomes trata do assunto com acuidade e sugere como fim dos trabalhos de fisiologia experimental a crise decorrente do que teria sido o ponto mais alto do Laboratório de Fisiologia Experimental: a descoberta do antidoto contra a picada de cobras.

140 COUTY, Louis. "Os estudos experimentais no Brasil”, op. cit., 1879, p. 235 . 
profundeza da superficialidade, e eliminar das grandes lutas as questões sem importância”. ${ }^{41}$

No Laboratório de Fisiologia, Couty procurou seguir o que ele propôs no artigo de 1879, como dizia ele ter "deixado ao pessoal a mais ampla liberdade de ação", em decorrência desse ato dizia ser "numerosos os trabalhos produzidos". ${ }^{142}$ Por isso, cabe ressaltar que esse artigo pode ser entendido como um projeto que ele elaborou, apresentou ao grande público ilustrado do Império e, sobretudo, procurou executar. Contudo, essa liberdade posta em prática por ele custou alguns atritos internos com o diretor geral Ladislau Netto.

O início da querela entre Couty e Ladislau Netto deu-se com a solicitação do diretor do Museu Nacional junto ao Ministério da Agricultura, sem consultar Couty, para que mudasse o lugar de armazenamento dos animais, que eram utilizados nas investigações. Ladislau Netto alegava que o salão ocupado pelos animais do Laboratório de Fisiologia não pertencia a este laboratório e exigia que o espaço fosse destinado às coleções do Museu. Havia, também, queixas sobre as condições higiênicas dos animais. Diante disso, Couty reagiu classificando a situação de arbitrária. ${ }^{143}$

Outra controvérsia entre Couty e o diretor geral deu-se em relação ao que Ladislau Netto classificou de "desrespeito do que prescreve a lei orgânica" do Museu

141 COUTY, Louis. "Os estudos experimentais no Brasil”, op. cit., 1879, p. 235.

142 COUTY, Louis. "Laboratorio de Physiologia Experimental”. In: Anexos ao Relatório do Ministério da Agricultura. 1882, s/p.

143 GOMES, Ana Carolina Vimieiro, op. cit., 2013, p. 53. 
Nacional, que se tratava do fato de Couty ter dado aos seus funcionários "o período de um mês para o fim do ano” e não os treze dias de férias regulamentados. Este ocorrido levou Ladislau Netto a enviar ofício ao Ministro da Agricultura denunciando esta irregularidade. No ofício Netto asseverava que oficiou Couty de sua "arbitrariedade" chamando-o ao "cumprimento do seu dever". Para tanto, Netto enviou a Couty "um exemplar impresso do regimento interno do Museu" para que tomasse conhecimento da irregularidade. Ladislau Netto recorre ao histórico de arbitrariedades que Couty, segundo ele, cometeu, como a que ocorreu entre os anos de 1880 e 1881 quando Couty não teria repassado a "sobra que houve na verba do laboratório", num total de dois contos de reis. ${ }^{144}$ Para resolver a contenda, Couty foi convocado, em janeiro de 1883 , por ordem do ministro da agricultura. ${ }^{145}$

Em sua defesa, Couty reclamou no Ministério da Agricultura, a necessidade da autonomia do Laboratório de Fisiologia. E sobre o mau uso da verba, Couty, asseverou que bastava apresentar ao Ministério da Agricultura a prestação de contas através das faturas quitadas e dos recibos dos instrumentos adquiridos na França. ${ }^{146}$ Interessante notar que no relatório do laboratório para os anos de 1880 e 1881, ou seja, antes de Netto questionar o não

\footnotetext{
144 Maço 189 - Doc. 8558: Ofício do diretor geral do Museu Nacional, Ladislau Netto, ao Ministro da Agricultura, Comércio e Obras Públicas. 1883. Arquivo da Casa Imperial.

145 Maço 189 - Doc. 8558: Ofício de José Agostinho Moreira Guimarães, Barão de Guimarães, ao diretor do Laboratório de Fisiologia Experimental do Museu Nacional, Louis Couty - Convocando-o, por ordem do ministro.

146 GOMES, Ana Carolina Vimieiro, op. cit., 2013, p. 53.
} 
repasse da verba, Couty relatava que "um saldo que ficou da verba de 1880-1881 foi há pouco remetido para a Europa, a fim de ser pagas outras encomendas já feitas”. ${ }^{47}$

Esses atritos entre o diretor do Laboratório de Fisiologia e o diretor Geral do Museu Nacional revelam a luta pela autonomia e liberdade de ação que Couty apregoou no seu artigo na Revista Brazileira e procurou por em prática em suas atividades no Laboratório.

A relação próxima de Couty com o Imperador fica sublinhada nessas querelas internas, sobretudo no conflito aberto entre Couty e Netto. Uma vez que Netto externou publicamente na imprensa seus descontentamentos com o vínculo administrativo entre o Laboratório e o Museu. Nesse cenário de disputas, Couty não mensurou esforços a fim de conquistar a autonomia desejada. Para tanto, em 1883, numa carta a Pedro II, expressava a necessidade da autonomia orçamentária para o andamento dos trabalhos que vinham sendo realizados no Laboratório de Fisiologia. E que, caso não fosse atendido em suas reivindicações ameaçava abdicar do cargo e rumar de volta à França onde seria bem recebido por Vulpian. ${ }^{148}$ Além disso, para corroborar o argumento de mais autonomia de Couty e reforço de seu capital científico, em 1881 ele já havia recebido e recusado convite para retornar a França como professor de fisiologia experimental na Faculdade de Medicina em Montpellier. Sendo esse fato muito elogiado na imprensa, com efeito, dizia a Gazeta de Notícias que "tão nobre o procedimento do jovem

\footnotetext{
147 COUTY, Louis. "Laboratorio de Physiologia Experimental”. In: Anexos ao Relatório do Ministério da Agricultura. 1882, s/p.

148 GOMES, Ana Carolina Vimieiro, op. cit., 2013, p. 136.
} 
e ilustrado professor não pode deixar de merecer as simpatias e os reconhecimentos dos brasileiros". ${ }^{49}$ Além disso, cabe ressaltar que Couty não recebia nenhuma remuneração para o cargo que ocupou no Laboratório de Fisiologia. ${ }^{150}$ Bastando-se financeiramente com o ordenado que recebia da Escola Politécnica. Entendemos que o Laboratório era menina dos olhos de Couty, era nele que ele aplicava seus conhecimentos de fisiologista e poderia se equiparar aos grandes nomes da área que pavimentaram sua contratação junto ao governo imperial.

Em carta ao Imperador dizia Couty: "Meu laboratório, sobretudo, e sua instalação que eu devo e eu sei a vossa Majestade, causaram a surpresa dos cientistas da Europa, habituados talvez a menos lentidão, mas também a menos generosidade". ${ }^{151}$ Esta carta é o maior indício do que foi para Couty o seu Laboratório e da íntima proteção que recebia do Imperador. Suas ações na ciência brasileira de final dos oitocentos estreitou com sólidos laços a produção científica brasileira com a francesa, tornando ele um mediador cultural, como atesta Ana Gomes para a esfera científica. Nesse aspecto, Couty com seus contatos na França estabelecia a conexão da produção do Laboratório com as revistas especializadas da Europa. Com efeito, de acordo com informações do relatório de Couty, Manoel Sallas (preparador do laboratório) e

149 Gazeta de Notícias, 16 mar. 1881.

150 Ministério da Agricultura. Relatório apresentado à Assembleia Geral na $4^{\text {a }}$ Sessão da $18^{\text {a }}$ Legislatura. 1883, p. 75.

151 Maço 185 - Doc. 8416. Cartas de Couty a D. Pedro II apud GOMES, Ana Carolina Vimieiro, op. cit., 2013, p. 136. 
Ribeiro Guimarães (assistente do laboratório) publicaram resultados de experiências "sobre a influência do calor solar" no Boletim da Sociedade de Biologia de Paris. Couty ao finalizar seu relatório enviado ao Ministério da Agricultura destacava a grande quantidade de trabalhos que, em tão recente prazo, o Laboratório realizou e, em nome dos trabalhadores do Laboratório pedia que continuasse "a auxiliar com sua benevolente proteção estes esforços úteis ao país". ${ }^{152}$

Podemos recorrer ao que disse, em 1891, Pedro II, quando se referia aos trabalhos de Couty e seu amplo reconhecimento, dizia: "O que aí fez o Dr. Couty tornou esse estabelecimento [Museu Nacional] conhecido na Europa”. Com esse trecho, podemos notar que existiu entre Couty e Pedro II um elo de recíprocas trocas de defesa dos interesses de ambos. Reforçando isso, em uma dessas defesas, Couty vai agir além dos seus Laboratórios, vai defender a imagem do país, numa defesa íntima do Imperador, que seria para Couty, o primeiro "abolicionista do Império".

\subsection{Internacionalização do abolicionismo brasileiro: o debate entre Louis Couty e Victor Schoelcher sobre a Lei do Ventre Livre de 1871}

Nas décadas de 1870 e 1880 a imprensa assumiu papel de vetor das críticas às instituições imperiais ao

152 COUTY, Louis. "Laboratório de Physiologia Experimental”. In: Anexos ao Relatório do Ministério da Agricultura. 1882, s/p. 
mesmo tempo em que a agitação revelava o aprofundamento das contradições da sociedade brasileira e despertava o interesse por reformas, que começavam a serem propostas e discutidas. Tais discussões eram pontilhadas pelas questões que revelavam o enfraquecimento das instituições imperiais como a questão da mão de obra, com as lutas em torno de algumas reformas de que dependia seu andamento, a liberdade do ventre, a da liberdade dos sexagenários e Abolição por fim; a questão religiosa, a questão eleitoral, a questão federativa, a questão militar, a questão do próprio regime, como coroamento do processo de mudança institucional. Questões e "reformas refletiam-se na imprensa, naturalmente, e esta ampliava a sua influência, ganha nova fisionomia, progredia tecnicamente, generalizava seus efeitos - espalhava o quadro que o país apresentava". ${ }^{153}$

Para além do Laboratório de Fisiologia Experimental e da cadeira de Biologia Industrial, foi este o ambiente que Louis Couty encontrou no Brasil. Várias questões davam o tom do que se passava no Império. Louis Couty foi um indivíduo de vários contextos, não se limitando ao ramo científico, foi além e subsidiou uma defesa veemente da imagem do país no estrangeiro. Dentre as questões citadas acima a que ele mais deteve atenção foi a questão servil, ou como preferia: problema da mão de obra. A questão da mão de obra, sumariamente, envolvia as discussões sobre o fim do trabalho escravo e a utiliza-

153 SODRÉ, Nelson Werneck. História da imprensa no Brasil. 3. ed. São Paulo: Martins Fontes Editora, 1983, p. 223. 
ção do trabalho livre do imigrante europeu, porém havia algo mais profundo, um debate sobre a organização da sociedade, sobre o futuro povo brasileiro.

Desse modo, alguns episódios e processos da história do Império permeiam o discurso de Louis Couty. Como sua inserção na constituição de um saber novo na ciência nacional que se consolidava, nesse sentido era ele parte do processo de introdução da fisiologia experimental. A condução e conceitualização da ideia de Biologia Industrial, que ele realizou na Escola Politécnica. Em outro momento teve como frente o movimento de vulgarização da ciência. Outro momento importante corresponde ao fomento de novos produtos para serem comercializados no mercado Europeu, como a erva mate, a carne seca. Esses novos produtos passariam pelo crivo da ciência e em seguida pela aceitação no mercado europeu. Houve com isso um esforço de vender novas possibilidades do país. Nesse âmbito, entendemos Couty como um mediador de uma nova imagem do país que se pretendia vender no exterior. Outro aspecto da inserção de Couty prioritários para essa pesquisa está relacionado ao modo de como ele encarou questões tão caras em seu momento, isto é, a questão da mão de obra com suas interfaces: escravidão, trabalhador nacional livre, imigração. No que se refere às questões da escravidão, sua intervenção contundente deu-se em 1881 quando combateu as ideias que para ele visavam desmerecer a força da Lei do Ventre Livre (1871) e a imagem do Imperador. Era o início do debate entre Louis Couty e Victor Schoelcher. 
O abolicionista francês Victor Schoelcher ${ }^{154}$ (18041893), notório nome mundial da causa abolicionista, com uma vasta publicação de livros sobre a escravidão em colônias francesas e inglesas, fez a público um pronunciamento em que fazia severas críticas à Lei do Ventre Livre (1871) brasileira. Sua fala ocorreu na sala do Grande Oriente de França durante um banquete na presença de personalidades francesas e estrangeiras. Nesse discurso, Schoelcher dizia que no Brasil "o ato de abolição de 1871" era "uma grosseira mentira”. E continuava notando que a obra de 1871 proclama:

Que o filho de uma escrava é declarado livre, mas com a condição de permanecer sob absoluta dependência do proprietário de sua mãe até a idade de 22 anos. Quando pensamos que não existem menos de 1.500.000 escravos no Brasil, percebemos que, se nos limitássemos a este decreto, este país não estaria purificado antes de decorridos dois séculos. O Imperador do Brasil, que todos dizem ser um homem liberal, deve sentir uma cruel humilhação por ser o único soberano do mundo civilizado que continua a reinar sobre escravos. ${ }^{155}$

154 DALE, Tomich. "Pensando o 'impensável': Victor Schoelcher e o Haiti”. In: Mana; v. 15, n. 1, Rio de Janeiro abril de 2009, p. 194. Schoelcher foi filho de um fabricante de porcelanas que recebeu do seu pai a missão de uma viagem de negócios no México, Flórida, Louisiana e Cuba em 1829 - 1830. Nessa viagem Schoelcher deparou-se com a realidade da escravidão no Novo Mundo descobrindo desde então a causa que dedicou pelo resto de sua vida. Depois dessa viagem publicou Lettres de Méxique, das quais a quarta carta era intitulada "Des noirs". Dizia ele que a escravidão era "uma cena dolorosa que nunca deixará minha lembrança”, apud op. cit., p. 195.

155 SCHOELCHER, Victor. "Discurso do Sr. Schoelcher". Anexo. In: COUTY, Louis. A escravidão no Brasil. Tradução: Maria Helena Rouanet. Rio de Janeiro: Fundação Casa de Rui Barbosa, 1988, p. 114-115. [grifo nosso]. 
Um golpe duro abateu o Monarca cidadão e seu cientista apadrinhado. Nesse momento Louis Couty estava na França sob a incumbência do governo imperial e leu o pronunciamento de Schoelcher na imprensa, no Le Temps, saindo também no La République Française. Diante do ocorrido, Couty prontificou-se a escrever uma carta em que julgava trazer a Schoelcher "informações relativamente mais completas". ${ }^{156}$ Procurou esclarecer a situação, à sua maneira, em defesa dos interesses do Império, sobretudo do Imperador. Na carta Couty se colocava responsável por "estudar aqui as questões da mão de obra e do povoamento" e que, portanto, tinha "o dever de fornecer-lhe informações suplementares que modificarão, creio eu, as suas opiniões atuais, mostrando-lhe tudo quanto este país realizou em prol da supressão da escravidão". ${ }^{157}$

Interessante notar que o pronunciamento de Schoelcher ocorreu em 5 de maio de 1881 e Couty respondeu em carta no dia 7 de maio daquele ano. Foi de imediato sua resposta. Couty faz uma longa defesa do Império, diz ele que naquele momento "uma emancipação brusca" era impossivel para o Brasil. Diferentemente da França, Inglaterra e América do Norte que pelos mais diversos motivos foram levados a suprimir a escravidão, mas que fizeram tal ato "sem pôr em risco a sua existência nacional ou sua evolução econômica”. No Brasil a causa era

156 COUTY, Louis. A escravidão no Brasil. Tradução de Maria Helena Rouanet. Rio de Janeiro: Fundação Casa de Rui Barbosa, 1988, p. 49. Este trecho da citação é a carta que Couty, com autorização de Schoelcher, colocou como prefácio de sua obra.

157 COUTY, Louis, op. cit., 1988, p. 50. 
outra, "toda a riqueza nacional e individual foi sempre baseada no trabalho escravo". Nestes termos, dizia Couty que "suprimir bruscamente a escravidão significaria suprimir ou reduzir todas as produções importantes, e fazer secar as fontes da renda nacional ou individual". Colocava uma pergunta claramente em defesa do Imperador: "pergunto ao Exmo. Sr. Senador se haverá um único estadista capaz de condenar o seu país a uma falência quase imediata e a uma completa convulsão[?]". ${ }^{158}$

Couty fez uma ampla defesa do Império, do Imperador e daqueles que queriam uma emancipação lenta e gradual. Mas o que motivou Couty a fazer tal ato? Defender um projeto pessoal que fora muito bem avaliado e patrocinado pelo imperador, alinhado ao projeto do Império para a ciência, sobretudo sua amizade com Pedro II, suas cartas pedindo intervenção em causas administrativas, eram aspectos que pesaram na decisão do jovem Couty em defender o Império e seus projetos. A repercussão da questão lhe garantiu, por um lado, o epíteto de amigo do Brasil, por outro lado um debate intenso com o movimento abolicionista que a partir do episódio Couty recrudesceu.

Essa controvérsia foi amplamente divulgada na imprensa brasileira. Após tratar da viagem de Couty na França a fim de ampliar o mercado dos produtos nacionais, a Gazeta de Notícias faz alusão ao debate envolvendo Couty e Shoelcher em Paris:

Ainda agora mesmo, durante a sua estada em $\mathrm{Pa}$ ris, ele sentiu-se obrigado a tomar a defesa do Brasil contra o venerando chefe dos antiescravagistas

158 COUTY, Louis, op. cit., 1988, p. 50-51. 
franceses, o Sr. Schoelcher, ao qual dirigiu uma carta, que seria em breve publicada com a resposta, aliás, dedicada e cheia de atenções, do mesmo Sr. Schoelcher. ${ }^{159}$

Esse episódio motivou Couty a publicar um livro, A escravidão no Brasil, que trataria da escravidão no Brasil, no que seria uma resposta mais completa e uma defesa mais embasada do reinado de Pedro II. Este livro levou Couty a entrar em outros aspectos da realidade imperial: histórico e social. De um cientista empenhado no desenvolvimento da ciência nacional, que se empenhava em transformar e aprimorar os produtos brasileiros e, com isso, abrir novas possibilidades comerciais, Couty cutucou a ferida da escravidão em um momento que o movimento abolicionista se estruturava, trazendo para si toda uma crítica dos abolicionistas. Nesse contexto, as críticas às estruturas imperiais se acentuavam e as ideias reformistas ganhavam corpo. Era momento decisivo da história do Império do Brasil.

No livro, Couty estabelece uma análise que, entre outras questões, suavizava as relações escravistas vigentes no Brasil e classificava D. Pedro II como "o primeiro abolicionista brasileiro", ${ }^{160}$ empreendia uma interpretação totalizante que exemplificava a escravidão por acontecimentos que o mesmo presenciou. Como a narração de uma cena idilica entre senhores e escravos:

159 Gazeta de Noticias, 11 jun. 1881. Essa notícia foi apurada a partir de uma carta que Couty enviou a João Baptista de Lacerda em 19 de maio de 1881, em que informava os passos da comissão cientifica que dirigia na Europa.

160 COUTY, Louis, op. cit., 1988, p. 49. 
Meu anfitrião chegou, seguindo de bandejas de frutas e de refrescos e pôs-se a preparar um magnífico abacaxi. Quase imediatamente, uma nuvem de rostinhos negros, mais ou menos espertos, de todas as idades, entre 5 a 12 anos, veio encher o vão da porta do salão que dava para o pátio de entrada. Admito que fiquei surpreso pela segunda vez. O Sr. Tibiriçá, percebendo minha reação, disse-me tranquilamente: 'Sempre que comemos abacaxi, aqui em casa, tenho o hábito de cortar primeiro um pedaço para eles; assim eles já sabem disto e vêm, como o senhor pode ver, pedir o seu pedaço', e, enquanto isto, como só tinha à mão um abacaxi bem maduro, foi-lhes dando muitos dos outros frutos que haviam sido trazidos e preparados para mim. ${ }^{161}$

Diante dessa cena fraterna, indagou Couty àqueles que "não tem o espírito prevenido", será que "existe na Europa muitas propriedades agrícolas cujo dono tenha tantos cuidados, tanta atenção, tanta verdadeira afeição para com seus assalariados?". Couty sabia que a resposta era não, pois seu objetivo era o de mostrar que o pronunciamento de Schoelcher não era verdadeiro ao trazer aspectos das relações entre senhor e escravos que não existiam, segundo ele, na França. Desse modo, Couty produz um retrato de uma escravidão branda, ${ }^{162}$ diferente

\footnotetext{
161 Idem, p. 98.

162 Celia Marinho de Azevedo entendeu Couty como aquele que lançou alicerces profundos para amparar as imagens paradisíacas da sociedade brasileira dos Oitocentos, suas descrições do Brasil como uma sociedade multirracial serviriam de argumento para atrair imigrantes, pois evidenciariam a ausência de conflitos étnicos - principalmente se comparassem a escravidão no Brasil com as da América Central: Haiti e do Norte: Estados Unidos. AZEVEDO, Celia Maria Marinho de. Onda Negra, Medo Branco, op. cit., 2008, p. 65-66.
} 
daquela que Schoelcher presenciou em sua luta abolicionista. Sobretudo, Couty vai notar que havia homens sábios no Brasil. Homens como o bondoso fazendeiro Tibiriçá, que dividia abacaxis com seus escravos. Que deixou Couty encantado com os livros que encontrou na mesa de trabalho desse seu anfitrião: "Darwin, Spencer, Lyell, C. Barnard, e, devo admitir, não era nem surpresa que os via ali, e que os via trazerem as marcas de uma leitura prolongada”. ${ }^{163}$

Por esse modo de tratar os escravos, pelas leituras, pela condução da produção agrícola, que os fazendeiros eram para Couty a classe mais importante do Império. Na sua divisão da sociedade brasileira, de 12 milhões de pessoas, dizia que aproximadamente "quinhentos mil" indivíduos "fazem parte das famílias proprietárias de escravos: são fazendeiros, advogados, médicos, funcionários, administradores, comerciantes" que produzem a riqueza do país. O restante da população livre "leva uma vida pouco produtiva, refugiando-se nas matas e zonas despovoadas, em geral muito afastadas". Nenhum desses homens era capaz de fornecer um trabalho agrícola ou industrial regular. Em síntese, observamos "a questão de uma forma mais abrangente e estudemos o conjunto da população, cuja situação funcional pode se resumir a uma palavra: O Brasil não tem povo". ${ }^{164}$ Era com isso em mente que Couty argumentava, em resposta a Schoelcher, a primazia da Lei do Ventre Livre (1871), posto que diante de uma abolição o que restaria ao fazendeiro, se

163 COUTY, Louis, op. cit., 1988, p. 98.

164 COUTY, Louis, op. cit., 1988, p. 102. 
o homem livre não mantém atividade regular? Por isso Couty estabeleceu uma análise que visou desqualificar os trabalhadores livres e libertos que tinham origem na fonte da escravidão. Sobretudo, tencionava ressaltar a força dos homens como os fazendeiros de valor como Tibiriçá. Senhores de escravos que no Brasil vem procurando "habituar os seus negros ao casamento, à propriedade, ao trabalho interessado e produtivo". Ou seja, tentando civilizá-los ao polir os maus hábitos. ${ }^{165}$ Desse modo, dizia ele que "os teóricos, que pretendem a igualdade entre todos os homens, talvez não tenham levado em conta o fato do negro que, uma vez libertado, quererá formar castas e não confundir todos os libertos". ${ }^{166}$ Para Couty, o negro livre não se tornaria melhor, continuaria a ser incapaz de realizar seus deveres sociais e de respeitar os direitos de seus concidadãos. Ele entende o negro como incapaz de realizar qualquer atividade do mundo civilizado, mas que quando isto acontece, o ato será mera representação, sem qualquer significado para o negro. Para tanto, dá o exemplo da ida do negro à igreja. Nesse ato percebe que suas práticas fariam inveja aos devotos mais convictos, mas os negros, dizia Couty, “jamais compreenderam as práticas que lhe fazem realizar, como também não sabem

165 O civilizar se relaciona com a "transformação polida: os bárbaros, os provincianos, os jovens, em suma a natureza 'feroz' e 'grosseira' antes que a arte se tenha encarregado dela para aperfeiçoar, isto é, alterá-la em um processo de suavização, de ornamento e de educação”. STAROBINSKI, Jean. As máscaras da civilização. Tradução de Maria Lucia Machado. São Paulo: Companhia das Letras, 2001, p. 28. Assim também se dava quando os fazendeiros do Brasil tentavam transformar os hábitos dos negros.

166 COUTY, Louis, op. cit., 1988, p. 100. 
nada a respeito dos dogmas que se thes fazem reverenciar”. Os negros teriam “o gosto pela imitação”, e isso permitiria que aprendessem ofícios difíceis, tornando relativamente suficientes em tal campo. Apesar de entender que o negro pudesse ser útil, Couty não via no negro a possibilidade do aperfeiçoamento, e por isso o máximo que alcançaria era uma condição secundária na estrutura social civilizada. Desse modo, resumia Couty que a permanência do negro "em uma nação civilizada, como o Brasil, e as grandes liberdades de que ele goza no país só serviram para modificar o seu exterior [...]". ${ }^{167}$ Essas características que Couty imputou ao negro estão no cerne da ideologia do branqueamento que tem Couty como um dos principais ideólogos. Nesses termos, se os negros, para Couty, eram incapazes de civilizar-se, deviam ser postos fora do processo de formação da civilização brasileira, do povo brasileiro. ${ }^{168}$

Foi esse o argumento que Louis Couty elaborou para contrapor o discurso de Schoelcher. Quis Couty

167 Idem, p. 101

168 Segundo Starobinski, "Um termo carregado de sagrado demoniza o seu antônimo. A palavra civilização, se já não designa um fato submetido ao julgamento, mas um valor incontestável, entra no arsenal verbal do louvor ou da acusação. Não se trata mais de avaliar os defeitos ou os méritos da civilização. Ela própria se torna o critério por excelência: julgar-se-á em nome da civilização. É preciso tomar seu partido, adotar sua causa. Ela se torna motivo de exaltação para todos aqueles que respondem ao seu apelo; ou inversamente, fundamenta uma condenação: tudo que não é a civilização, tudo que lhe resiste, tudo que a ameaça, fará figura de monstro ou de mal absoluto. Na excitação da eloquência, torna-se permissivel reclamar o sacrifício supremo em nome da civilização. O que significa dizer que o serviço ou a defesa da civilização poderão, eventualmente, legitimar o recurso à violência. O anticivilizado, o bárbaro devem ser postos fora da condição de prejudicar, se não podem ser educados ou convertidos” (2001, p. 33). 
demonstrar que na estrutura da sociedade brasileira, uma parte dos elementos que a constituíram era de fato útil, eram os fazendeiros, advogados, médicos, etc. A outra parte, a grande maioria dos homens livres, e libertos, vegetavam. Por isso, a abolição precisava ser gradual e nisso a Lei do Ventre Livre cumpria sua função. Do contrário, com a abolição sem reformas, o país entraria em crise. Nesse caso, não era fácil para um estadista, como Pedro II, conduzir as reformas sem crises maiores, por isso a abolição gradual seria o meio capaz de levar o país a um estádio sem escravidão.

A repercussão de seu livro na imprensa foi grande, recebeu críticas favoráveis e golpes veementes de oposição, em especial da imprensa abolicionista. Em texto publicado pelo Jornal do Commercio referente ao livro de Couty, encontramos sinais claros do lugar de amigo do Brasil que Louis Couty passou a ocupar na grande imprensa da Corte. O título da nota, "Escravidão no Brasil”, reproduzia o título do livro de Couty. A folha fez um exame da questão social da escravidão no Brasil como uma introdução para chegar a análise do livro de Couty. Desfere críticas à falta de exatidão na fala do Senador abolicionista francês Schoelcher; atenta para a defesa de Couty para com o Brasil; releva os erros históricos e mesmo os factuais de Couty, enfatizando as suas contribuições importantes para o país. ${ }^{169} \mathrm{O}$ texto iniciava com uma constatação representativa do perfil que a folha procurava veicular: "Onde se trata de escravidão e de escravos há para nós lugar obrigado, como derradeiros

169 Jornal do Commercio, 28 jun. 1881. 
representantes, que somos entre os povos cultos, desse triste legado que tem sido rémora do nosso progresso e inelutável obstáculo a nossa definitiva organização social e econômica [...]". ${ }^{170}$ Assumia para si um dever de estar de prontidão para as causas da escravidão, que, segundo a folha, era o obstáculo ao desenvolvimento do país, de seu progresso. Esse era um dos climas quando se pensava sobre escravidão, de uma forma ou de outra, entendia que a organização social advinda do modo escravista seria um obstáculo ao livre desenvolvimento do país rumo ao progresso e a civilização.

Adiante a folha evidenciou a realização de esforços empregados "para nos limparmos dessa mácula”, que em parte "alguma ainda se mostrou em proporções tão temerosas quanto no Brasil”. A partir disso, traz inquietações a respeito da maneira como "somos julgados incompletamente", de um ponto de vista que não descortina "todos os acidentes que abrangem o horizonte da vida de um povo em cujo seio, pela estimação mais favorável, há um escravo para nove homens livres". ${ }^{171}$

O texto elabora uma forma de mostrar, seguindo as formulações de Couty, que existia um processo e meios contrários ao que se apresentava modelado pela escravidão, que havia uma obra em defesa da emancipação dos escravos. Que havia um movimento contrário à escravidão. Isto porque o texto expõe que o discurso de Schoelcher foi realizado na presença de figuras de notório destaque nas causas pertinentes a abolição da escravidão

170 Idem.

171 Idem. 
na época, como exemplo Gambeta e outras autoridades francesas e estrangeiras, ou seja, a imagem maculada do Império era exposta a um grande público de notáveis.

No discurso, diz o jornal, Schoelcher, "ocupando-se do estado da questão da escravidão em nossa pátria, exprimiu conceitos só explicáveis pela ignorância em que mais tarde reconheceu laborar a respeito das coisas do Brasil”. De modo indignado, o Jornal do Commercio declarava não entender por qual método Schoelcher chegara a tal ilação, de que "em menos de dois séculos não teremos expungido a nódoa da escravidão". ${ }^{172}$ Era nesse momento que diante da fala objurgatória do abolicionista francês, Louis Couty levantou-se contra e escreveu um opúsculo, L'esclavage au Brésil, precedido de uma carta a Schoelcher em que procurou, segundo o jornal, demonstrar "fazendo votos pela aceleração do desfecho do grave problema e aduzindo considerações, fundadas na observação pessoal para por em relevo a superioridade do trabalho livre sobre o trabalho escravo". 173

Diante do episódio, para a folha Louis Couty tirava “o Brasil de muita pecha iniqua”. Posto que, reivindicava para a "lei Rio Branco o alto apreço moral" que merecia a lei. Sobretudo, acentuou "a tendência emancipadora que tão vivaz se mostra em nosso país”. E que,

dá como fato provável que o fim do século, tendo visto desaparecer entre nós a escravidão pela transformação que se opera, presidirá aos destinos do Brasil como aos do único país que terá

172 Jornal do Commercio, 28 jun. 1881.

173 Idem. 
realizado o generoso sonho de M. Schoelcher: um estado social em que o negro, completamente igual ao branco, compartilha de todas as funções do nosso organismo. ${ }^{174}$

Corroborou a afirmativa de Couty, que "a lei de 1871 nunca foi considerada um maximum, e que a maioria dos brasileiros, alistados ou não em sociedades abolicionistas, busca meios de chegar à solução do problema mais rapidamente do que aquele grande ato deixa esperar". ${ }^{175}$

A preocupação era de dissolver uma imagem negativa de que havia um aceite por completo da escravidão na sociedade brasileira, evidencia-se assim uma visão daqueles que viam na escravidão uma necessidade gradual e daqueles que se empenhavam na luta contra o trabalho escravo. Contudo o jornal se preocupava em colocar que o desejo do fim da escravidão era universal no Brasil:

O ilustre professor podia dizer as universalidades dos brasileiros, porque nenhum há, com efeito, que deseje ver acabar a escravidão ao pé da cova do último escravo. Os que mais apreensivos se têm mostrado sobre o curso desta questão, não consideram a lei de 28 de setembro como as colunas de Hercules, além das quais não é dado passar. ${ }^{176}$

Com apreço agradecia a pronta resposta de Couty a Schoelcher. Contudo, não deixou de fazer ressalvas aos erros contidos no livro: "O livro de M. L. Couty, se contêm inexatidões, desculpáveis a um estrangeiro, primeiro a

\footnotetext{
174 Idem.

175 Idem.

176 Jornal do Commercio, 28 jun. 1881.
} 
pedir que lhe as indiquem, é no seu aspecto geral uma obra de consciência". ${ }^{177}$

A folha lista algumas inexatidões existentes na obra de Couty, dentre elas a de que "os senhores de escravos são obrigados a manter escolas para os filhos destes" e que "os castigos corporais tenham sido interditos ou limitados..." ou de que, "nestes últimos quatro anos, 40.000 escravos têm sido alforriados pela filantropia particular".

Todavia,

estas e outras inexatidões não desmerecem, contudo, o valor relativo do livro de M. L. Couty. Este professor visitou algumas das nossas províncias do sul, viu com seus próprios olhos o regime da escravidão em numerosas fazendas e estâncias, e se, como é natural, lamenta a sorte do escravo e a sorte de quem é obrigado a tê-los, trouxe insuspeito testemunho, de que não devemos envergonhar-nos. ${ }^{178}$

Louis Couty possuía, portanto, a visão de quem viu de perto a realidade da escravidão e como homem da ciência seu olhar e suas considerações eram conscientes e quando comparadas ao olhar que operava com abstrações sobressaía e ganha características de verdadeiras. Assim, o autor do texto do Jornal do Commercio asseverava as ações de Couty como favoráveis aos interesses do país. A imagem de Couty como "amigo do Brasil" se consolidava para seus coevos. Contudo, houve outro lado que contrapôs às conclusões de Couty sobre a escravidão no Brasil.

177 Idem. [grifo nosso].

178 Idem. [grifo nosso]. 


\subsection{0 abolicionismo contra Couty}

A Sociedade Brasileira Contra a Escravidão através de seu impresso O Abolicionismo, analisou, também, o livro de Louis Couty, da mesma forma que o Jornal do Commercio, logo em seguida de sua publicação. A chamada para o artigo tinha o título "Livro do Dr. Couty". O texto, no início, trazia considerações técnicas sobre o livro e logo em seguida asseverava que "Os estrangeiros não têm a mesma razão de tomar a peito a causa da emancipação que temos nós, brasileiros. Para eles a reputação moral e a constituição liberal do país valem muito pouco". ${ }^{179} \mathrm{O}$ que se procurava passar era que Couty, como estrangeiro, não tinha autoridade para tratar de assuntos nacionais.

No texto, o autor estabeleceu duas visões sobre o negro, a do cientista e a do abolicionista. A tese nova, como a afirma o autor, "é que o negro não é igual ao branco”. Estava atento às teorias racialistas que pululavam dos laboratórios dos cientistas. Para em seguida pouco importar se existe ou não superioridade racial entre negros e brancos: "O Dr. Couty ocupa-se do negro cientificamente, como professor de um museu; para nós, porém, os negros são cultivadores do nosso solo, um elemento considerável da nossa população [...]”. É interessante notar as relações que o texto faz com termos científicos, biológicos ou sociológicos: "A nós interessa por enquanto pouco saber se o negro é biologicamente ou sociologicamente inferior ao branco". Para em seguida concluir o parágrafo chamando atenção para o cálculo desigual que a

179 O Abolicionismo, (01 de agosto de 1881). A Sociedade Contra A Escravidão tinha como sede a capital do Império. 
escravidão colocava, “[...] Inferior ou superior, não há razão alguma para que duzentos, trezentos e quatrocentos negros trabalhem para um branco. Se eles são inferiores, para que o foram roubar ao seu continente, fora do qual, e em contato com o branco, eles degeneram?". ${ }^{180}$

Mais adiante, entrando no aspecto da Lei de 28 de Setembro de 1871, o autor do texto concorda com as ponderações de Couty quando este assegurou, na carta a Schoelcher, que em menos de trinta anos ter-se-ia a supressão completa da escravidão.

Contudo,

deixando este último ponto, que se pode muito debater sem chegar a nenhum resultado, todas as outras afirmações do Sr. Couty são enganos deploráveis da parte de um professor de uma das nossas Academias, que fala ao Sr. Schoelcher em virtude do conhecimento que diz ter das nossas causas. ${ }^{181}$

A aproximação de Couty a Schoelcher soa como lamento de uma situação vexatória em que alguém sem saber do assunto põe-se a falar como entendido. Provavelmente, era essa a ideia que se fazia de Couty esta Sociedade e outras pessoas que estavam desse lado do debate sobre a escravidão. Posto que, "O Sr. Couty pintando com cores apagadas a escravidão no Brasil, quis somente consolar os indivíduos e o governo interessados na liquidação, sem danos e perdas, dessa complicada sucessão". ${ }^{182}$

180 Idem.

181 O Abolicionismo, $1^{\circ}$ ago. 1881.

182 O Abolicionismo, $1^{\circ}$ ago. 1881. 
Apesar de considerar os argumentos de Couty sobre a Lei do Ventre Livre, em certa medida, aceitáveis, o autor do texto concluía citando trecho da resposta que o abolicionista Schoelcher deu a Couty:

A última palavra nessa polêmica entre o Sr. Couty e o Sr. Schoelcher devia, porém, caber a este benemérito da humanidade. Por isso transcrevemos o final da resposta que ele deu ao seu compatriota. 'Trinta anos de escravidão, com as suas degradações, os seus castigos corporais, as suas vendas de homens, mulheres e crianças, como animais domésticos ou coisas, impostos a um milhão e quinhentas mil criaturas humanas, é um prazo longo de mais para que os amigos da humanidade possam a ele resignar-se'. ${ }^{183}$

A observação mais aceitável de Louis Couty seria desqualificada pela resposta do abolicionista francês Schoelcher. Desse modo, Couty era classificado pelos abolicionistas como alguém que mascarou o que de fato era a escravidão no Império brasileiro. Dois anos mais tarde, em 1883, Joaquim Nabuco usaria esse mesmo trecho da carta de Schoelcher a Couty como epígrafe para seu O Abolicionismo. ${ }^{184}$

Esse episódio de Couty se enlaçou com as questões mais urgentes da última década do Império. Marcou, para um lado da sociedade imperial, sua imagem de amigo do Brasil. Desse modo, entendemos este momento como o clímax de sua narrativa sobre o Brasil. Sobretudo, porque

\footnotetext{
183 O Abolicionismo, $1^{\circ}$ ago. 1881.

184 NABUCO, Joaquim. O abolicionismo. Rio de Janeiro: Nova Fronteira; São Paulo: Publifolha, 2000, p. 23.
} 
foi a partir desse momento que ele viu necessidade estudar os "costumes" e "características sociais", abrindo mão como ele diz do "estudo das raças e dos caracteres étnicos". Especialmente porque no Brasil dizia ele que "o liberto entra plenamente em uma sociedade na qual ele é imediatamente tratado como igual”. Formando-se assim uma mestiçagem que fazia do Brasil um lugar onde "inexiste o preconceito racial". Sobretudo, porque "esses mestiços misturam-se inteiramente à população branca”, mantendo "relações íntimas e cotidianas". ${ }^{185}$

Devemos enfatizar que não foi toda a sociedade imperial que abraçou a defesa que fez Couty das condições da escravidão no Império. Sobretudo, não abraçou a descrição paradisíaca das relações raciais no país. O movimento abolicionista, como narramos, subsidiou intensa crítica ao que Couty realizou em Paris. Crítica que perdurou até a morte de Couty em novembro de 1884 . Desse modo, entendemos que da reação do movimento abolicionista ao que disse Couty ao prócer dos abolicionistas, foi um lance decisivo para o momento mais ativo do abolicionismo. Ao mesmo tempo foi o lance que colocou Couty como amigo do Brasil. Da publicação de $A$ escravidão no Brasil em 1881 até O abolicionismo em 1883, podemos notar uma relação de debate pelos textos entre Couty, que resumia as ideias imigrantistas e rechaçava o negro como elemento ativo na formação do povo, e o movimento abolicionista que criticava a postura segregacionista de Couty.

185 COUTY, Louis. A escravidão no Brasil, op. cit., 1988, p. 52. 


\subsection{1 "Meu laboratório" que "eu devo e eu sei a vossa Majestade"}

O momento que Louis Couty assinalou no seu artigo "A missão de um homem", como citamos no início desse capítulo, teve como ponto importante o debate entre ele e Schoelcher. Que recrudesceu a partir de então. A missão de D. Pedro II era, para Couty, a de convergir os ambivalentes interesses da abolição, a fim de que seguissem uma única direção. Contudo, meses depois de "A missão de um homem", Couty demonstrou que a melhor ação seria a de fazer as reformas via imigração.

Desse modo, notamos como Couty elaborou a defesa dos interesses do Império, isto é, do Imperador, baseado na relação mutua que se estabeleceu entre ele e Pedro II, que mediou sua vinda ao país, dando a possibilidade de ação sonhada por qualquer homem de ciência de seu tempo. Indícios dessa relação estão nas cartas que Couty enviou a Pedro II, em que reportava a admiração e surpresa que seus colegas franceses expressaram quanto às condições de ciência que ele tinha no Brasil. Encontra-se, também, na consideração que fez Couty ter em Pedro II o "primeiro abolicionista" brasileiro. Por sua vez, Couty mediou a defesa dos interesses e da imagem do Império, fazendo desse momento seu clímax no país. Doravante a este clímax veremos como Couty agiu e pensou o Império do Brasil. 


\section{$\{3\}$}

\section{Ciência em Expansão: o percurso de Louis Couty pelo Império}

Com verdadeira surpresa e prazer, confesso, vi pela primeira vez os vastos cafeeiros, cultivados esmerada e perfeitamente, cujo grão de importância não é ainda apreciado no estrangeiro [... ${ }^{186}$

A natureza bruta, sorrindo, tingia as córneas do cientista de esperança e, as possibilidades de transformar e aumentar ainda mais o que se via, ganhavam formas e fórmulas com as ferramentas que a ciência lhe dava. Louis Couty tinha noção do futuro - posto que dele veio, de um acelerado processo de industrialização e desenvolvimento urbano que se espalhava pelo Velho Mundo - que estava à espera do Brasil. ${ }^{187}$ Transformar era seu mote e por isso Couty deixava de ser um viajante que

186 COUTY, Louis. "A Cultura do Cafeeiro na Província de São Paulo”. In: Jornal do Agricultor: principios práticos de economia rural, Rio de Janeiro, ano 1, tomo 1, p. 161, jul./dez. 1879. (Editor Proprietário: Dias da Silva Junior). Essa menção ao fato de o café não ser apreciado no estrangeiro é resultado do que mais tarde o próprio Couty e o holandês Van Delden Laerne revelariam sobre a confusão que se fazia na hora da venda do café brasileiro no mercado europeu.

187 Sobre a industrialização e modernidade do velho Mundo Cf. BERMAN, Marshall. Tudo o que é sólido desmancha no ar, op. cit., 2013. HOBSBAWM, Eric. A era do capital (1848-1875). Rio de Janeiro: Paz \& Terra, 2002. 
via e relatava para ser um cientista que identificava problemas e buscava soluções. Homem de ciência, não perdia tempo nem possibilidades de agir para o progresso do país que o acolheu com garantias de grandes possibilidades profissionais.

Um lugar no Brasil se diferenciava, Couty via numa província, "pelas ideias de progresso de que se acham possuidos" seus fazendeiros, algo semelhante ao futuro: "Por toda a parte lavra-se a terra; por toda a parte plantam-se novos pés de café, empregando-se cuidados mais completos". Assim, quem visitasse a província de São Paulo "tão ativa e florescente" viria a "fecundidade sem exagerações prodigiosas" do seu solo e de sua gente. ${ }^{188}$

A expansão cafeeira do centro-sul demandou terras, mão de obra e capital, ${ }^{189}$ mas, além disso, demandou a introdução do saber científico com a finalidade de curar

188 COUTY, Louis. "A Cultura do Cafeeiro na Província de São Paulo". In: Jornal do Agricultor: princípios práticos de economia rural, Rio de Janeiro, ano 1, tomo 1, p. 161, jul./dez. 1879. (Editor Proprietário: Dias da Silva Junior).

189 A respeito da expansão cafeeira - em sua dimensão política, econômica e social - que compreende as regiões da província do Rio de Janeiro, zona da Mata mineira, as regiões do vale do Paraíba na sua parte paulista e o oeste paulista e as relações de trabalho que ela demandou conferir entre outros: BEIGUELMAN, Paula. A Formação do Povo no Complexo Cafeeiro: aspectos Políticos. 2. ed. São Paulo: Biblioteca Pioneira de Ciências Sociais, 1978. COSTA, Emilia Viotti. Da Senzala à Colônia. 2. ed. São Paulo: Ciências Humanas LTDA, 1982. HOLLOWAY, Thomas H. Imigrantes para o café: café e sociedade em São Paulo, 1886-1934. Tradução de Eglê Malheiros. Rio de Janeiro: Paz e Terra, 1984. LANNA, Ana Lúcia Duarte, “O Café e o trabalho 'Livre’ em Minas Gerais (18701920)”. In: Revista Brasileira de História, v. 6, n. 12, mar./ago., 1986. SILVA, Sergio. Expansão cafeeira e as origens da indústria no Brasil. São Paulo: Alfa-Omega. 1980. STOLCKE, Verena e HALL, Michael M., "Introdução do trabalho livre nas fazendas de café de São Paulo”. In: Revista Brasileira de História, n. 6, setembro de 1983. 
as moléstias do cafeeiro, fabricar equipamentos que melhorassem a qualidade e que até reduzissem a utilização da mão de obra escrava visando o aumento da produção e dos preços. Eram também com esse fim que agiam o Museu Nacional (Laboratório de Fisiologia Experimental) e Escola Politécnica (Biologia Industrial) as duas instituições científicas importantes do Império, pelas quais Louis Couty realizava suas missões científicas.

Desde o início do século XIX, a produção do café como item de exportação vinha aumentando. Em 1828, as cifras de exportação colocavam o Brasil como o maior produtor mundial de café. Quase toda a produção vinha da região do Vale do Paraíba, ou "Vale da escravidão" para Couty, ${ }^{190}$ estendendo uma porção de terra que compreendia as províncias do Rio de Janeiro, São Paulo e Minas Gerais. ${ }^{191}$

No Vale do Paraiba fluminense, inicialmente o café ocupou a região ocidental (Rezende, Vassouras, Valença e Barra Mansa), atingindo a partir de 1840 a plaga oriental (Cantagalo, Bom Jardim e Itaperuna). Na província mineira, na Zona da Mata (Juiz de Fora, Mar de Espanha e Leopoldina) a expansão cafeeira atingia, em 1850, uma produção significativa e na década seguinte estabelecia a montagem das ferrovias. ${ }^{192}$ Em São Paulo, a produção cafeeira espraiava-se nas terras do Vale do Paraíba

190 COUTY, Louis. "O Brasil no interior e os clubes da lavoura". (1 a 5 jun. 1884). In: O Brasil em 1884, op. cit., 1984, p. 245.

191 MARQUESE, Rafael Bivar; TOMICH, Dale. "O Vale do Paraiba escravista e a formação do mercado mundial do café no século XIX". In: GRINBERG, Keila; SALLES, Ricardo. O Brasil Imperial (1831-1870). Rio de Janeiro: Civilização brasileira, 2009, p. 341-342.

192 GONÇALVES, Paulo Cesar. Migração e mão de obra: retirantes cearenses na economia cafeeira do Centro-Sul (1877-1901). São Paulo: Associação Editorial Humanitas, 2006, p. 39-40. 
paulista (Areias, Bananal e Silveiras) parelha às plantações de cana de açúcar. Ulteriormente corria para as regiões centrais (Campinas, Rio Claro, Jundiaí, Itu, Piracicaba e etc.). Em fins dos Oitocentos, as plantações alcançavam a região da Mogiana (Araraquara, São Carlos, Ribeirão Preto e etc.). No último quartel do século XIX, o café produzido na província paulista ultrapassaria o café produzido na província fluminense. ${ }^{193}$

Acompanhando o desenvolvimento agrícola do café, desde seu início, estava a mão de obra escrava que dominou as produções até a década de 1880, momento em que o número de imigrantes nas fazendas passava a ser sensivelmente notado por Louis Couty, que "andando pelas fazendas", podia fazer uma observação geral: "o escravo parou por todos os lugares, ou quase todos os lugares"; deixava de ser "o único trabalhador". Notava Couty que, de Cantagalo a São Paulo, "nas dezessete fazendas" que visitou "se utiliza o trabalhador livre nos diversos trabalhos, e especialmente nos trabalhos mais difíceis do engenho". ${ }^{194}$

Em 1880 entraram na província de São Paulo 613 imigrantes. Em 1881 o número de imigrantes mais que triplicou chegando a 2.705. No ano de 1882 o número se manteve quase estável, entrando 2.743 imigrantes. No ano seguinte, em 1883, o número evoluiu para 4.912. Em 1884, chegaram 4.868 imigrantes. A partir de 1887,

193 GONÇALVES, Paulo Cesar. Migração e mão de obra, op. cit., 2006, p. $40-43$.

194 COUTY, Louis. Étude de biologie industrielle sur le café: rapport adressé à M. le directeur de l'Ecole Polytechnnique. Rio de Janeiro: Imprimerie du Messager du Brésil, 1883, p. 116. 
a entrada de imigrantes mais que triplicou. No total a década de 1880 recebeu 183.505 imigrantes. ${ }^{195}$ A presença do escravo no processo de expansão cafeeira vinha sofrendo alterações. Já se via o trabalhador livre atuando nas diversas funções de uma fazenda. Alguns desses imigrantes que, pouco a pouco, chegavam às fazendas de café eram "pedreiros, carpinteiros", responsáveis pelas máquinas e pela poda do cafeeiro, eram "italianos, alemães, alugados durante todo ano" segundo Couty "por um preço elevado". ${ }^{196}$

Louis Couty percorreu as regiões da produção cafeeira incumbido de um uma missão: colher e examinar dados a respeito do que se passava nas produções de café e a partir daí propor melhorias com a finalidade de aumentar a vendagem no mercado mundial de café. Além das regiões de café, foi até a região sul e do Rio da Prata analisar a erva mate e a carne seca, sempre com a finalidade de melhorar a atuação desses produtos no mercado mundial. ${ }^{197}$ Foi com as técnicas proporcionadas pela ciência que ele analisou o solo e as plantas que cobriam este solo e o homem que manejava o solo.

195 Citado em: GONÇALVES, Paulo Cesar. Mercadores de braços, op. cit., 2012 , p. 183.

196 COUTY, Louis. Étude de biologie industrielle sur le café, op. cit., 1883, p. 116.

197 O relatório do Ministério da Agricultura frisava as atribuições do responsável pela cadeira de biologia industrial: "Dr. Louis Couty, lente contratado de biologia industrial na Escola Politécnica, [tem] a tarefa de proceder a estudos sobre a fabricação da erva mate nas províncias do Paraná, S. Pedro e Repúblicas do Prata, incumbindo-o ao mesmo tempo de outras indagações úteis à lavoura e aos diversos ramos da indústria pastoril". Ministério da Agricultura. Relatório apresentado a Assembleia Geral Legislativa $3^{\text {a }}$ sessão da $17^{\text {a }}$ Legislatura. 1879, p. 163. 


\subsection{Ciência para aprimorar a produção}

Nada mais lindo que ver um cafezal de 6 a 7 anos, com seus arbustos praticamente iguais, separados por espaços suficientes que fornecem floração regular e a completa maturidade dos frutos. ${ }^{198}$

Em 1879, Louis Couty apresentou seu primeiro relatório sobre a cultura do café em São Paulo. Para tanto, percorreu quatro fazendas onde vistoriou o solo indicando alguns procedimentos que deveriam ser realizados no modo de tratar o cafeeiro. As quatro fazendas visitadas pelo cientista foram: Sete Quedas, Ressaca, Morro Azul e Tapera. Na fazenda Tapera, de "excelente terra massapé”, observou um verdejante cafezal de sete anos que tinha cada pé um do outro uma distância de quinze palmos em média. Contudo, notava que as raízes estavam "inteiramente entrelaçadas". Cavando a terra em diversos pontos constatou que as raízes "de 1 a 3 milímetros de grossura formavam uma rede filamentosa”. Com isso, chegava à conclusão de que "o solo das plantações, já invadido ao cabo de 7 ou 8 anos" ficava mais tarde todo preenchido e "sobrecarregado pelo entrelaçamento das raízes". Esse entrelaçamento das raízes do cafeeiro comprometeria mais tarde a produção, ficando "os pés de café não só privados de terra virgem”, mas também de ar. Ao chegarem aos 12 ou 14 anos, "quando atingem completo desenvolvimento" deveriam dar o máximo de produção, mas isso não acontece posto que "os ramos se ligam, se

${ }^{198}$ COUTY, Louis. Étude de biologie industrielle sur le café, op. cit., 1883, p. 12 . 
enlaçam e formam uma copa única, na qual o ar e a luz penetram dificilmente", diminuindo a produção. ${ }^{199}$

Detectado o problema era preciso chegar à sua resolução, que seria no caso do cafeeiro "o espaçamento maior dos pés de café”. Para tanto, Couty fazia "um apelo ao zelo e iniciativa dos fazendeiros" para que plantassem os pés em uma distância de 16, 18, 20 ou até 24 palmos a fim de comparar "durante alguns anos a produção" e observar os resultados obtidos com o procedimento adotado. Acreditava Couty que com maior espaçamento a produção aumentaria e diminuiria incidência de moléstias que atacavam o café. Além da maior incidência do sol sobre os pés de café proporcionar um crescimento mais saudável, proporcionaria uma melhora na qualidade dos grãos, que ficariam "mais maduros e perfeitos". ${ }^{200}$

O maior espaçamento entre os pés facilitaria a ação do sol que cumpriria sua função, porém para a "plena expansão e, sobretudo abundante frutificação" o cafeeiro necessitava de incrementos químicos como o uso da potassa, do ácido fosfórico "que as terras, ainda as mais ricas, possuem em quantidade relativamente diminuta". Couty propunha ao cafeicultor que deixasse entre os pés "uma zona de terra virgem" que serviria como uma espécie de reservatório que forneceria "nutrição aos cafeeiros mais antigos". Cumprindo as indicações do cientista o cafeicultor notaria que com a medida de aumentar o espaçamento entre os pés, além do aumento da produção

199 COUTY, Louis. "A Cultura do Cafeeiro na Província de São Paulo", op. cit., 1879 , p. 161.

200 COUTY, Louis. "A Cultura do Cafeeiro na Província de São Paulo", op. cit., 1879 , p. 162. 
e da qualidade dos frutos, ficaria mais fácil o uso dos "instrumentos aratórios" puxado por animais que seriam para Couty "melhor e menos custosa" forma de trabalho se comparada com o "custoso" trabalho do escravo. ${ }^{201}$

Outro aspecto que Couty detalhou em seu primeiro relatório se refere ao processo da poda no cultivo do cafeeiro. Quanto a isso, observou que quando o cafeeiro estava por demais copado, com seus ramos "tomando desenvolvimento exagerado”, era preciso executar a poda dos ramos. Nesse caso, não cabia apenas um espaçamento entre os pés, mas um tratamento mais cuidadoso com a prática da poda. Segundo Couty, o emprego da poda era praticado nas fazendas Morro Azul e Ibicaba, ${ }^{202}$ mas seria como ele indica, posto em prática também na fazenda Sete Quedas. Notou que a prática da poda no manejo do cafeeiro era pouco usual ${ }^{203}$ nas fazendas de café, suscitando “objeções não justificadas" por parte dos cafeicultores. ${ }^{204}$ Propondo ser conveniente a experiência da poda, indicava o processo:

\footnotetext{
201 Idem, p. 161-162.

202 Nesse primeiro relatório Louis Couty não visitou a fazenda Ibicaba para empreender seus estudos. Foi no segundo e mais completo relatório que trouxe mais aspectos da economia cafeeira após vistoriar dezessete fazendas, entre elas Ibicaba.

203 A poda do cafeeiro como técnica de melhoria do cultivo era uma prática antiga no Brasil e em outros países. Entre as décadas de 1830 e 1840 o agricultor Carlos Augusto Taunay escreveu um manual agricola em que realizou algumas observações sobre a poda do cafeeiro. Aconselhava ele que no Brasil "o uso de podar é mais apropriado ao clima, pois que sendo o terreno mais forte e abundante em sucos do que na Arábia, as chuvas muito mais frequentes, e o ar menos seco, tudo tende a aumentar o volume da espessura da folhagem à custa da fruta”. TAUNAY, Carlos Augusto. Manual do agricultor brasileiro. Organização de MARQUESE, Rafael Bivar. São Paulo: Companhia das Letras. 2001, p. 126.

204 COUTY, Louis. "A Cultura do Cafeeiro na Província de São Paulo", op. cit., 1879, p. 161-162.
} 
A operação da poda é fácil; pode ser feita por trabalhadores pouco destros, não traz inconveniente algum para o vegetal sendo praticada pouco a pouco, ano por ano, e dá com certeza resultados excelentes, quer sob o ponto de vista da abundancia dos frutos, quer sob o da maior duração do período de produção. Demais, mantendo o desenvolvimento do cafeeiro nos limites convenientes, asseguraria sempre abundante circulação de ar e de luz, facilitando também o emprego dos instrumentos aratórios. Assim, de todos os modos favoreceria e tornaria mais completa a nutrição do cafeeiro. ${ }^{205}$

No caso do emprego da poda como prática agrícola no manejo do cafeeiro, ela deveria ser uma operação executada a partir da iniciativa do fazendeiro com o auxílio do saber científico que se especializava no assunto. Como indicou Couty, nesse processo de introdução do saber científico nas operações agrícolas a "utilidade da operação em si" não poderia "ser posta em dúvida". Contudo, como notou Couty, houve certa objeção do cafeicultor em relação ao método da poda. Mas Couty tinha convicção de que "combinando-se o emprego da poda com um plantio melhor dos cafeeiros", obter-se-iam "não só safras maiores e provavelmente menos desiguais, mas também o menos rápido enfraquecimento dos arbustos, podendo os cafeeiros conservar o máximo de produção", não apenas por 5 a 10 anos, "mas por muito mais tempo". ${ }^{206}$

A preocupação era proporcionar uma harmonia na produção e na qualidade dos frutos com a finalidade de

205 Idem, p. 162.

206 Idem, p. 163. 
melhorar o sabor do produto e seu preço final. Para obter melhor resultado final era preciso, além da intervenção manual no cafeeiro, a montagem de equipamentos que dariam um padrão ao processo. Notava Couty que "os fazendeiros compram instrumentos aratórios, de tipos diferentes, e procuram utilizá-los”, mas que o progresso era "lento demais" e os instrumentos empregados, além de caríssimos, eram "muito imperfeitos e insuficientes". ${ }^{207}$ Apesar da má qualidade dos instrumentos empregados, Couty calculava que seu uso "substitui o trabalho de cinco escravos”. Portanto, poderia "diminuir de 4/5 a mão de obra na operação tão longa da capina”. Couty viu o uso desse instrumento puxado por cavalo nas fazendas Tapera, Ressaca e Morro Azul. Nas fazendas Sete Quedas e Morro Azul, as máquinas de beneficiar eram as mais aperfeiçoadas que até então tinha ele encontrado, tornando possível preparar "rápida e excelentemente o café". 208

Anos mais tarde (1883) em seu relatório mais completo, comparando o incremento de instrumentos e máquinas nas plantações de café nas províncias do Rio de Janeiro e São Paulo, notou que em 1879 tinha visto "pequenas charruas de fabricação inglesa" que em sua maioria quebravam facilmente na primeira utilização e que em sua segunda expedição tinha notado uma evolução com o uso da carpideira, que fazia as vezes dos arados e das enxadas. Apesar de considerar a incisão da carpideira menor que a do arado, Couty via nesse instrumento um aliado, não só por que abria a terra um pouco

207 Idem, p. 163.

208 Idem, p. 164. 
mais que a enxada - instrumento considerado inferior por Couty -, mas também porque auxiliava na economia do uso da mão de obra. ${ }^{209}$

Nessa primeira vistoria de 1879 , que consideramos de reconhecimento, Louis Couty concluía alertando para a necessidade da transformação da mão de obra. De todos os problemas que ele encontrou no Brasil o da mão de obra foi o que mais o inquietou. Era importante enfatizar e insistir "sobre essas questões", dizia ele, "se o faço é porque se ligam intimamente à solução do momentoso problema que ora interessa tão perto o Brasil: o problema da mão de obra". ${ }^{210}$

Desse modo, colocava nesse relatório oficial que era preciso "tornar a mão de obra mais fácil, menos sobrecarregada e custosa, sem diminuir a produção”. Era esse, com efeito, "o problema que atualmente se impõe aos fazendeiros". Para resolvê-lo era preciso substituir o "excessivamente caro" trabalho escravo por instrumentos aratórios, puxados por animais. Nesse primeiro relatório entrou pouco no assunto da imigração como alternativa para a falta de braços. Contudo não deixou de considerar a mão de obra escrava cara e rara. Com a iminência do fim da escravidão, pontuava que a falta de braços na lavoura poderia "ser suprida, ao menos em parte, pelos animais e as máquinas agrícolas”. ${ }^{11}$

209 COUTY, Louis. Étude de biologie industrielle sur le café, op. cit., 1883, p. 26-27.

210 COUTY, Louis. "A Cultura do Cafeeiro na Província de São Paulo”, op. cit., 1879, p. 163. [grifo nosso].

211 Idem, p. 163. No primeiro artigo de grande repercussão na imprensa da Corte questionava: "a mão de obra escrava deve ser substituída pelas maquinas agrícolas? Efetivamente será este o meio mais 
O trabalho de Couty serviu para ampliar as possibilidades de produção e qualidade dos produtos agrícolas através da introdução de equipamentos e melhoramentos que a ciência desenvolvia. Nesse primeiro relatório, a questão central aparece como investigação da possibilidade de introdução de processos mecânicos como alternativa para a melhora do cultivo e para a falta de braços. A questão da imigração que seria tão importante em momentos seguintes aparece pouco nesse primeiro relatório de 1879. O problema "grave e complexo da transformação do trabalho escravo em trabalho livre, em um país em que a mão de obra é já excessivamente cara, e, não obstante, escassa; em um país em que apesar de rarearem os braços, se tenta, todos os anos, novas e enormes culturas e trabalhos industriais consideráveis”, seria tratado, como ele indica, no próximo relatório. ${ }^{212}$ Em 1879 o melhor conhecimento a ser empregado se daria através de técnicas e instrumentos aratórios a fim de possibilitar uma alternativa ao alto custo da mão de obra escrava.

\subsection{Viagens ao Sul do Império: o mate, a carne seca e a busca de novos mercados}

Antes de estabelecer-se no Império em 1879, Louis Couty realizou uma série de estudos sobre a erva mate a pedido do governo imperial, já em função de suas obrigações

adequado de tornar o trabalho menos raro e, sobretudo menos caro". COUTY, Louis. "Os estudos experimentais no Brasil”, op. cit., p. 223.

212 COUTY, Louis. "A Cultura do Cafeeiro na Província de São Paulo", op. cit., 1879 , p. 164. 
como futuro professor da Escola Politécnica do Rio de Janeiro e membro correspondente do Museu Nacional. Estas primeiras investigações sobre os efeitos fisiológicos do mate realizou na França, no laboratório do fisiologista Vulpian. Os primeiros resultados seriam apresentados na Academia de Ciências de Paris. Em agosto de 1878, o general Morin comunicava o imperador Pedro II sobre o andamento das investigações fisiológicas de Couty e sobre as compras dos equipamentos para a Escola Politécnica que coube a Couty. ${ }^{213}$

No Brasil deu continuidade aos trabalhos que iniciou na França. Em dezembro de 1879 era noticiada sua chegada à Curitiba:

Acha-se nesta capital o Sr. Dr. Louis Couty, professor substituto de Medicina de Lion, professor de Biologia Industrial da Escola Politécnica e fisiologia experimental do museu, em comissão do governo nas províncias do Sul. ${ }^{214}$

A folha destacava a importância dos estudos que Louis Couty estava realizando sobre o "ramo mais importante de nossa indústria provincial”. Sua recepção nessa trajetória enfatizava o papel que o homem de ciência desempenhava nesse momento, onde grandes expectativas industriais e agrícolas eram atribuídas aos seus trabalhos. Com efeito, para o jornal de Curitiba os estudos de Couty “será por certo de grande utilidade para o Paraná”, posto que, "pouco conhecido ainda é [o mate] no estrangeiro".

213 GOMES, Ana Carolina Vimieiro. Uma ciência moderna e imperial, op. cit., 2013, p. 77.

214 O Paranaense, 21 dez. 1879. 
Outro jornal paranaense, a Província do Paraná, sublinhou a missão que Couty realizava, enfatizou os trabalhos do francês e traduziu a nota científica sobre o mate que tinha sido apresentada na Academia de Ciências de Paris em 1878. Nessa nota científica, Couty concluía destacando o caráter alíbil do mate e, sobretudo, seu valor fisiológico para o médico clínico e higienista, que seria de grande importância se, "como se pode esperar, esta substância pouco custosa e muito ativa, tornar-se mais geralmente usada como agente terapêutico e alimentício". ${ }^{215}$ Estas primeiras investigações de Couty sobre os efeitos do mate no organismo não tiveram grandes progresso. Contudo, não fora de todo mal. Passaram por exames de outros cientistas como os doutores Hoffmann, professor de Berlim, e o professor Kletgensky de Viena, que julgaram a bebida agradável, "restauradora, higiênica e econômica". ${ }^{216}$

Nessa missão às regiões sul do país, que se estendeu até a Argentina, Couty estudou a erva mate, a carne seca, a pecuária de um modo geral e conversou com proprietários da região a fim de "facilitar a introdução da mesma erva nos mercados europeus”. ${ }^{217}$ De acordo com informações que a folha O Apostolo obteve de Couty, o mate que o cientista encontrou era "muito mal preparado, quer nas matas de onde é extraído, quer nos numerosos engenhos que o fabricam". Contudo, observou que "alguns melhoramentos" começavam a ser introduzidos "por inteligentes fabricantes”. Após as viagens pelo Paraná,

215 Província do Paraná, 18 dez. 1879. Essa nota cientifica de Louis Couty foi apresentada por Vulpian na França.

216 Ministério da Agricultura. Relatório apresentado a Assembleia Geral Legislativa $3^{\text {a }}$ sessão da $17^{\text {a }}$ Legislatura. 1879, p. 163.

217 O Apostolo, 9 jan. 1880. 
Couty rumou à província do Rio Grande e as províncias do Rio da Prata e Argentina para o mesmo realizar com o mate e carne seca daqueles locais. ${ }^{218}$

Deslocando-se para o Rio Grande do Sul, estudou a pecuária e os processos de preparo da carne seca e fomentou a expectativa quanto ao futuro desse produto no mercado europeu. A imprensa da Corte noticiava que “o Sr. Dr. Couty não hesita em classificar [a carne seca] como alimento incontestavelmente superior às conservas de carne até agora em uso na Europa”. Para tanto, mobilizava Couty sua rede científica quando remeteu de Porto Alegre "200 quilogramas de carne seca ao sábio químico francês Achille Morin” que se colocava disposto a auxiliar na tentativa de comercializar esse produto na Europa. Ulteriormente Morin enviaria uma remessa do produto ao "Dr. Hamont, intendente militar e médico distinto; para fazer experimentar o uso da carne seca por algumas companhias do exercito francês". Morin teria um papel importante nesse movimento de ampliar a inserção dos produtos alimentícios brasileiros no mercado europeu. ${ }^{219}$ A extensão dessa missão dirigida por Louis Couty cumpriria partes da função ao ter os resultados das pesquisas publicados nas revistas especializadas da Europa. Era o caso da Rèvue d'Hygiène, dirigida por Vallin, que publicaria as experiências de Couty. ${ }^{220}$

Depois de seis meses em missão pela região sul Couty retornava a capital do Império. A volta das expedições foi objeto da notícia, bem como as novas instalações do novo laboratório de fisiologia no qual seria diretor. ${ }^{221}$

218 Idem.

219 Jornal do Commercio, 25 jan. 1880.

220 Jornal do Commercio, op. cit.

221 O Apostolo, 30 maio 1880. 
Para ter um futuro promissor como produto de exportação, era preciso divulgar as potencialidades comercias do mate em território nacional. Isto é, antes de abrir novos mercados no estrangeiro, era preciso abrir novos centros de produção do mate no Império. Com isso, o Ministério da Agricultura fomentou a divulgação dos estudos que Couty fizera no Sul. Era preciso cativar novos produtores. Numa circular do ministro Manoel Buarque de Macedo, ressaltava-se a necessidade de divulgar as potencialidades do mate, para tanto dizia ele: "remeto a V. Ex. 50 exemplares do relatório que me apresentou o Dr. Couty sobre os estudos que procedeu por ordem deste ministério, acerca da erva mate e da carne seca”. 222 Era destacada a importância de que

esses estudos cheguem ao conhecimento de todos os moradores do Império, e principalmente daqueles que se empregarão nos dois ramos da indústria de que se trata; recomendo a V. Ex. que pelos meios a seu alcance procure dar toda publicidade ao relatório, ou pelo menos a excertos dele criteriosamente escolhidos. ${ }^{223}$

Em outra parte do texto publicado lia-se:

Deste relatório remeto a V. Ex. seis exemplares, que $V$. fará distribuir pelas redações das gazetas diárias e periódicos de maior crédito e circulação desse estado na esperança de que, tratando-se de

222 "Circular n. 7 - Rio de Janeiro, 4 de dezembro de 1880 - Ministério dos negócios da agricultura, comércio e obras publicas em 4 de dezembro de 1880". In: Publicador Maranhense - Propriedade de Ignnelo José Ferreira - Maranhão, 5 jan. 1881.

223 Idem. 
assunto de tamanha magnitude, elas não deixarão de publicá-lo ou integralmente ou em excertos, e de contribuir com suas observações para a solução prática da questão a que não é lícito a nenhum governo deixar de atender. ${ }^{224}$

Havia um esforço de divulgação exercido pela circularidade dos relatórios ministeriais através território. Nas províncias, num âmbito local, estava a imprensa ocupando função de divulgação mais direta. Com isso, os estudos realizados por Louis Couty tinham amplo alcance.

\subsection{Nos Laboratórios, os produtos da nação}

Nos Laboratórios de Biologia Industrial e Fisiologia Experimental, Louis Couty realizou com sua equipe várias investigações fisiológicas a fim de constatar o caráter nutritivo dos produtos brasileiros: o café, a erva mate e a carne seca. Tornaram-se estes laboratórios espaços onde se dava as trocas de saberes visando, sempre, beneficiar os produtos nacionais. Cabe ressaltar, a importância da ação de dois funcionários do Laboratório de Fisiologia Experimental nesse processo de investigações mais aprofundadas sobre as qualidades dos produtos: café, mate e carne seca. Quanto a isso, Manoel de Sallas (o preparador) e Ribeiro Guimarães (assistente), sob a direção de Couty, fizeram algumas pesquisas sobre o mate "delas resultando entre outros fatos o seguinte: que este alimento é capaz de manter a vida por longo tempo". Isto é, o

224 Idem. 
animal utilizado no experimento teria maior tempo de vida ao ingerir apenas o mate numa comparação com outro alimento. Além desses experimentos, dizia Couty que eles "encetaram estudo sobre diversos venenos ou alimentos do Brasil" e que sob sua direção "executaram as numerosas e difíceis experiências do curso que fiz este ano no Museu sobre as funções do cérebro". Todos os resultados dos trabalhos dos dois eram publicados, como enfatizava Couty, nos periódicos franceses. ${ }^{225}$

A constituição da rede de atuação de Couty se deu com forte interesse do Imperador e do governo imperial. Pensemos num movimento, do Imperador mobilizando seus conhecimentos e amigos cientistas que atuavam na França, dos amigos de Pedro II, em solo europeu, atuando em prol dos anseios do monarca, no caso Morin e Vulpian e destes indicando Louis Couty para ocupar as funções de professor e diretor dos laboratórios em solo brasileiro. Couty vindo ao Brasil, reconhecendo as especificidades do país em sua trajetória, indicando os problemas e soluções; arregimentando homens de ciência e de outras diretrizes, ampliando suas conexões que atuaram com Couty nas idas e vindas a fim de ampliar o mercado para os produtos nacionais na Europa. Com isso, constituiu-se uma ampla rede de sociabilidades que se posicionou em função dos produtos nacionais e de sua assimilação no mercado europeu. Feito isto, o reconhecimento da qualidade seria o reconhecimento do país. O Museu Nacional a partir das reformas realizadas por

225 COUTY, Louis. "Laboratório de Fisiologia Experimental”. In: Ministério da Agricultura. Relatório do Ano de 1881 apresentado à Assembleia Geral Legislativa $\mathrm{Na} 1^{\text {a }}$ Sessão Da $18^{\mathrm{a}}$ Legislatura. 
Ladislau Netto em meados da década de 1870 já desenvolvia um trabalho intenso de pesquisa e de trocas de informações entre as instituições cientificas congêneres da Europa e Estados Unidos. Nesse sentido, Couty veio somar mais conhecimento pelos contatos que possuía na comunidade científica internacional. Veio ele para o Brasil recomendado pelas mais renomadas autoridades do mundo científico. A ligação entre Louis Couty e o general francês Morin granjearia importantes aliados na missão cientifica de consolidar os produtos brasileiros no mercado mundial. No primeiro relatório (1879) evidenciava seu percurso e entre os objetivos, o de

fazer no laboratório de biologia industrial da escola politécnica uma série de experiências a fim de determinar as condições físicas de um bom e completo dessecamento artificial do café, a fim de comparar a rapidez do dessecamento do café verde e do meio seco, do café em cereja e do despolpado, a fim de estabelecer os limites desse dessecamento e estudar as modificações químicas que determina no grão do café $[\ldots]^{226}$

Outra etapa do projeto elaborado por Louis Couty cumpriria função na "vulgarização científica" dos produtos por ele e sua equipe estudados. Os trabalhos e artigos seriam publicados nos Comptes Rendues e nas "revistas e jornais mais apreciados da Europa". Assim, ligava as necessidades do Império às demandas científicas da comunidade de cientistas estabelecida na Europa tendo ele

${ }^{226}$ COUTY, Louis. "A Cultura do Cafeeiro na Província de São Paulo", op. cit., 1879, p. 164. 
como elo. Poderia "então apresentar os resultados destas experiências” em conexão com os estudos "encetados pelo general Morin, no Conservatoire des Arts et Métiers de Paris; estudos que este ilustrado sábio teve a bondade de me comunicar, incitando-me a continuá-los. ${ }^{227}$ Couty atuou nessa ampla rede de saberes como um importante nexo na mediação de conhecimentos e transformação do país.

\subsection{A Propaganda dos produtos: uma missão para Couty}

Em 1881, o Ministério da Agricultura incumbia Louis Couty de dirigir uma missão até a França a fim de divulgar e abrir novos mercados para alguns produtos da produção brasileira: o mate e a carne seca. Para a realização dessa missão de divulgação, Couty contou com a participação de dois professores da Escola Politécnica, Goffredo d'Escragnolle Taunay e Augustos Carlos da Silva Telles. ${ }^{228}$

Os homens de ciência do século XIX atuavam nas frentes que a ciência e as inovações técnicas lhes possibilitavam. Empenhavam-se em conhecer para tornar reconhecidos os produtos do portfólio da agricultura. Médicos, fisiologistas, biólogos, botânicos, engenheiros, inventores, construíam o contexto científico do Império atuando nas causas da agricultura. Como observa Hobsbawm, os "homens cultos do período [segunda metade do XIX] não estavam apenas orgulhosos de suas ciências, mas

\footnotetext{
227 Idem, p. 164.

228 Ministério da Agricultura. Relatório apresentado à Assembleia Geral Legislativa na $1^{\text {a }}$ Sessão da $18^{\text {a }}$ Legislatura. 1881, p. 207.
} 
preparados para subordinar todas as outras formas de atividade intelectual a elas" ${ }^{229}$ A causa era nobre e em nome da ciência e do progresso partia-se mesmo sem auxílio financeiro.

Sabendo nós que despesas, aliás relativamente insignificantes e cuja natureza indicaremos, poderiam ser necessárias, tínhamos pedido auxílio e apoio do Governo; tal auxílio, verbalmente prometido, foi depois subordinado a uma aprovação das câmaras necessariamente tardia e afastada. Era, porém, inconveniente deixar passar largo tempo sem prosseguir na Europa os estudos iniciados aqui; por isso decidimo-nos a não esperar e, só contando com o apoio moral do Governo, abalançamo-nos a tentar conseguir com recursos próprios o que julgávamos útil a tal respeito. Se, nestas condições, os nossos estudos ficaram incompletos em certos pontos e deixamos de fazer coisas importantes, é justo de reconhecer que a culpa não nos deve ser imputada. ${ }^{230}$

\subsection{O "café do pobre", a carne seca e o café}

A ida a Europa de Louis Couty, Goffredo Taunay e Augusto Telles tinha o escopo de ampliar o mercado para os produtos brasileiros que Couty havia pesquisado em

229 HOBSBAWM, Eric. A era do capital (1848-1875), op. cit., 2002, p. 349.

230 COUTY, Louis; TAUNAY, Luiz Goffredo de Escragnolle; TELLES, Augusto Carlos da Silva. Propaganda na Europa do mate, do café e da carne seca. Relatório apresentado ao Conselheiro José Antonio Saraiva. Ministro e Secretario de Estado dos Negócios da Fazenda e interino do da Agricultura, Comércio e Obras Publicas. Anexo ao relatório do Ministério da Agricultura, 1881, p. 5. 
seu percurso pelo Sul do Império. Levava-se nessa missão o conhecimento de dois produtos que teriam boas possibilidades de mercado na Europa, como havia indicado Couty. Dos produtos levados, mate e carne seca, sobretudo, o mate foi, segundo os relatores, o "que deu-nos mais trabalho, ocupou-nos mais tempo e, também, a que fizemos progredir mais sensivelmente". ${ }^{231} \mathrm{O}$ mate aparecia com grandes possibilidades para o Ministério da Agricultura, no futuro "terá de ocupar importante lugar na ordem dos nossos gêneros de exportação". Não apenas para o mercado europeu se orientava os trabalhos de introduzir o mate, pensava-se também no mercado dos Estados Unidos. ${ }^{232}$

Para a realização da missão, Couty, Taunay e Telles elaboraram um projeto de ação. Era preciso fazer do mate um alimento conhecido, isto é, possibilitar que fosse apreciado no continente europeu, especialmente na França. Para tanto, os responsáveis pela missão optaram por duas medidas: "começar o seu emprego por ensaios bem dirigidos e estabelecer e patentear o valor do produto por indagações e publicações científicas”. ${ }^{233}$ Mas uma questão surgia: "Como, porém, espalhar esse produto, fazê-lo saborear e, sobretudo, adotar por modo seguido?”. Para tanto, os responsáveis pela missão elaboraram

231 COUTY, Louis; TAUNAY, Luiz Goffredo de Escragnolle; TELLES, Augusto Carlos da Silva. Propaganda na Europa do mate, do café e da carne seca, op. cit., 1881 , p. 6.

232 Ministério da Agricultura. Relatório apresentado a Assembleia Geral na $2^{\text {a }}$ Sessão da $18^{\text {a }}$ Legislatura. 1881, p. 92.

233 COUTY, Louis; TAUNAY, Luiz Goffredo de Escragnolle; TELLES, Augusto Carlos da Silva. Propaganda na Europa do mate, do café e da carne seca, op. cit., 1881 , p. 6. 
um método para a inclusão do mate como alimento na França. A forma de introdução foi pensada e concluiu-se que a melhor maneira de agir se daria no "exército" por onde passava a maior parte da população da França "e que serve de amalgama, de meio comum a todas as classes sociais". Pensou também nos "hospitais de convalescentes e asilos pelos quais passam também numerosos operários". ${ }^{234}$

Estabelecido os lugares mais apropriados para a execução da missão, era preciso, diante do preço pouco elevado do mate e do seu preparo imperfeito, "evitar uma competição de mercado entre o café e o mate”. Caso essa competição acontecesse, temia-se que "teria o país problemas", sobretudo, porque o Brasil figurava como produtor dos dois produtos. Desse modo, convencionou introduzir o mate como o "café do pobre" ou das "classes laboriosas", do operário, do camponês e etc. ${ }^{235}$ Assim, a produção do Império não sofreria impactos negativos e teria pela frente um amplo mercado.

Para a proposta do uso do mate ser aceita realizou-se investigações científicas com amostras enviadas de Curitiba à França pelo produtor Ildefonso Corrêa, que remeteu aproximadamente 400 quilos de mate. Com as amostras em mãos, designou-se uma comissão militar para o exame do mate e também da carne seca, composta por Gervais, coronel de estado maior, Courand farmacêutico de primeira classe do exército francês, Barret, intendente incumbido do serviço dos viveres do exercito

234 Idem.

235 Idem. 
de Paris. O general Friant esteve presente para assistir as experiências que se realizaram em maio de $1881 .{ }^{236}$ Nesse mesmo momento Couty estava em debate com o abolicionista francês Victor Schoelcher como já analisamos.

Seguindo os experimentos, o produto resultante do preparo com o mate não agradou o general Friant. Procurou se em seguida uma defesa, apelando pela qualidade da remessa enviada. Em carta, Ildefonso Corrêa pediu desculpas por emitir uma remessa de pouca qualidade e se prontificou a mandar algo mais selecionado e assim o fez. Enquanto isso, foram realizados novos ensaios pela comissão, chegando a conclusão "que era impossível tirar dos mates recebidos uma bebida aceitável”. As investigações eram realizadas no Colégio de França e demonstraram que das amostras, três ou quatro vezes tinham menos ativos do que os experimentados, em 1877, por Couty e fornecidos pela Legação do Brasil em França. ${ }^{237}$

A estratégia de divulgação do mate se dava em várias frentes e uma delas foi a de publicar as investigações científicas nas revistas especializadas da França. Louis Couty havia publicado na Revista de Higiene de Paris uma série de artigos, cujos escritos tinha um duplo fim:

Patentear que a alimentação dos povos da América do Sul é aparentemente muito diversa da Europa e, em realidade, lhe é superior não só pelo valor alíbil e a variedade dos produtos como pela

236 COUTY, Louis; TAUNAY, Luiz Goffredo de Escragnolle; TELLES, Augusto Carlos da Silva. Propaganda na Europa do mate, do café e da carne seca, op. cit., 1881 , p. 7.

${ }^{237}$ Idem, p. 8. A carta que o produtor de mate Ildefonso enviou aos realizadores da missão encontra-se anexa ao relatório. 
abundância e baixo preço; tornar conhecidas substâncias alimentícias por demais ignoradas: a carne seca, o mate, a mandioca, mesmo o café e o açúcar do Brasil. ${ }^{238}$

Quanto ao mate, depois de ter indicado o modo de prepará-lo e os seus usos atuais, Couty insistia nas vantagens que resultariam da sua adoção, sobretudo, para as classes operarias que, não dispondo de recursos suficientes para comprar vinho ou café, eram obrigadas a apenas beber água pura ou bebidas inferiores. ${ }^{239}$ Ulteriormente Couty publicou um trabalho na Revista Scientifica que logrou boa repercussão. O êxito dessa publicação deu-se com a reprodução de partes do texto nos jornais de grande circulação de Paris, abrangendo um público geral. Com a popularização do artigo de Couty, o editor da revista notava que "pela simples leitura dessas observações" muitos "homens de valor" tornaram-se "partidários declarados de uma substância" que ainda nem conheciam. Como apontado no relatório, o próprio Imperador recebeu cartas em que eram solicitadas porções do mate brasileiro. Louis Couty também recebeu cartas de "engenheiros, médicos, professores" que escreveram diretamente a ele demonstrando interesse nesse novo produto. Com isso uma parte dos objetivos de divulgar o mate obtivera êxito. Com efeito, alguns negociantes franceses escreveram a Couty e ao fazendeiro Ildefonso

238 Idem, p. 9.

239 COUTY, Louis; TAUNAY, Luiz Goffredo de Escragnolle; TELLES, Augusto Carlos da Silva. Propaganda na Europa do mate, do café e da carne seca, op. cit., 1881, p. 9. 
Corrêa, para serem "depositários desse produto novo no qual tem confiança”. ${ }^{240}$

Está, pois, iniciado um verdadeiro movimento de vulgarização. [...] É necessário, porém, estender este movimento, alargá-lo, se não se o quer ver extinguir-se e nós mesmos sabendo que um simples artigo - qualquer que seja, aliás, o valor de sua publicação - não pode bastar [...]. ${ }^{241}$

Baseados nos resultados, realizados por Couty, que demonstraram que os cães submetidos ao uso do mate comiam menos carne e pão "sem nada perderem" da "agilidade habitual", os relatores colocavam ênfase na "demonstração cabal da ação do mate e a prova de seu grande valor alimentício". ${ }^{242}$ Além desses meios demonstrados, tentou-se expor o mate em um evento anual restrito aos produtores franceses, mas que poderia cada casa expositora tratar de divulgar, fora do certame, produtos de outros países. Contudo, ao contatar as autoridades brasileiras para a realização de tal iniciativa, informam que "o pouco interesse ligado aos nossos esforços” obrigaram a não prosseguir na proposta. Desse modo, justificavam a falta de maior êxito na missão notando que "a culpa em grande parte recai, porém, sobre a má qualidade do produto que nos fora enviado e a insuficiência, convêm dizê-lo, dos meios de ação de que dispúnhamos". 243

Todavia, ao pouco interesse do governo em incentivar a exposição do mate no evento francês, bem como o

240 Idem, p. 10

241 Idem, p. 10

242 Idem, p. 11.

243 Idem, p. 11-12. 
fracasso da introdução do mate como alimento no exército francês, em certa medida, os resultados teriam sido interessantes, posto que o consumo do mate conquistou aumento significativo na França em decorrência da missão chefiada por Louis Couty. Como prova a carta que os relatores da missão receberam do responsável pela organização do evento:

Podemos nos orgulhar de ser os iniciadores, ao menos em França, de um movimento persistente, uma agitação em torno do mate a ponto de, como nos escrevia anda há pouco Mr. Thomaz: 'não se passar agora dia sem que, em Paris, se deixe de vender mate, aumentando gradualmente os pedidos dos departamentos para a compra dessa substância'. ${ }^{44}$

Apontado os sucessos e as falhas, Couty, Taunay e Telles indicavam como deveria ser o meio pelo qual os produtores de mate deveriam agir para estabelecer essa nova exportação que "deve enriquecer todo o sul do Brasil”. Era preciso que os esforços se dessem em parceria entre o governo e particulares. Aos particulares caberia arcar com os trabalhos e despesas para a fabricação de um produto agradável à vista e sempre igual em qualidade. Além de buscar na Europa intermediários e comerciantes para alcançar o consumidor. Ao governo caberia a iniciativa de continuar a propaganda do mate brasileiro, procurando provar o valor nutritivo do produto em novos mercados. ${ }^{245}$

${ }^{244}$ COUTY, Louis; TAUNAY, Luiz Goffredo de Escragnolle; TELLES, Augusto Carlos da Silva. Propaganda na Europa do mate, do café e da carne seca, op. cit., p. 12.

245 Idem, p. 13. 
No relatório, os autores indicavam a necessidade de criar uma casa de comércio para a venda do mate na Europa. Esta casa deveria ficar sob a gerência dos produtores do mate. Com o estabelecimento desta, criaria se marcas específicas a fim de habituar o consumidor a um produto de boa qualidade. Sobretudo, "os esforços dirigidos por este modo servirão verdadeiramente para tornar conhecido e aceito o mate e também para enriquecer mais tarde os produtores em lugar de deixar quase todos os lucros em mãos de intermediários [...]". 246

Em relação à carne seca, os resultados conquistados foram menores devido ao fato da carne utilizada nos experimentos ser de procedência duvidosa como asseveravam os relatores, sendo considerada indigesta pela comissão francesa que avaliou o produto. Couty indicava que o problema se encontrava na criação do gado, que por sua vez era criado solto no pasto, sendo isto um dos fatores da indicada má qualidade do produto. Um dos responsáveis pela reprovação da carne colocava o problema da seguinte maneira: "o gado da América do Sul é de má qualidade e a Europa não aceitará nunca esta carne meio selvagem sem gosto nem aroma, dura e fibrosa”. ${ }^{247}$ Por isso Couty aconselhava que o gado fosse criado em pastos fechados.

O café nessa missão não seria abordado, como atestam os relatores, mas o que encontram Couty, Taunay e Telles, motivara-os a trazer informações a fim de que se

\footnotetext{
246 Idem, p. 15.

247 COUTY, Louis; TAUNAY, Luiz Goffredo de Escragnolle; TELLES, Augusto Carlos da Silva. Propaganda na Europa do mate, do café e da carne seca. 1881, p. 32.
} 
atentasse para um problema que atrapalhava a venda do café. Ao questionar alguns vendedores de café de Paris se havia café brasileiro, recebiam como resposta que "não vendiam tais marcas por serem inferiores". Contudo, "era fácil reconhecer, nos seus armários ou sacos, cafés do Brasil com denominações de outras procedências". ${ }^{248}$ Anos mais tarde, em viagem pelas regiões produtoras de café do Rio de Janeiro e de São Paulo, o holandês Van Delden Laerne corroborou essa inversão do café, dizendo que o melhor café brasileiro era vendido como se fosse café de Java e o pior café de Java era vendido como se fosse brasileiro. ${ }^{249}$

Outros problemas em relação ao café foram encontrados, como o da vendagem do café, que segundo os relatores oferecia ao comissário um lucro muito alto. Enquanto o produtor recebia menos da "metade do valor real de sua colheita”. De acordo com os cálculos elaborados, o café "dobra de preço" antes de chegar ao último vendedor. ${ }^{250}$ Esses problemas encontrados levaram os relatores a concluir que a crise pela qual passava a produção cafeeira teria origem no custo de produção do café, que no Brasil "é exagerado". Se o custo era exagerado, era "devido à natureza da mão de obra, que é cara e má, e ao seu emprego direto em excesso". ${ }^{251}$ Desse modo, era proposto que algumas funções na produção do café poderiam ser executadas por máquinas. Com a introdução de máquinas o café deixaria de ter uma produção

\footnotetext{
248 Idem, p. 18.

249 Correio Paulistano, 18 jan. 1884.

250 COUTY, Louis; TAUNAY, Luiz Goffredo de Escragnolle; TELLES, Augusto Carlos da Silva. Propaganda na Europa do mate, do café e da carne seca. 1881, p. 19.

251 Idem, p. 24.
} 
irregular como é o aspecto decorrente da produção realizada pelo escravo. Somente por meio "de máquinas se pode separar os cafés do Brasil, tão irregulares de forma, de modo a apresentar cada lote grãos sensivelmente do mesmo tamanho" [sic]. Com máquinas teria a produção uniformidade e poder-se-ia, com esses requisitos, criar marcas de café ou de mate e carne seca. ${ }^{252}$

\subsection{A máquina como solução}

Com a finalidade de demonstrar que a produção de café aumentaria e seria de melhor qualidade com a introdução de processos mecânicos, Couty, Taunay e Telles, se valem de uma descrição do processo industrial europeu que falava por si, ganhando vida.

O que caracteriza, no velho continente, as usinas de transformação agrícola é a completa centralização das operações, a sua simplicidade e automatismo. A matéria-prima viaja, passa de uma à outra máquina, é submetida sucessivamente a série de operações de seu preparo - como se, dotada de vida, procedesse de motu próprio [...]. ${ }^{253}$

Era um modelo a ser seguido, o progresso estava no processo que se assemelhava ao da vida em um ritmo sem fim. É disso que o Brasil precisa, talvez tenha pensado um dos três homens ou, quiçá, os três. Posto que, os

252 Idem, p. 27.

253 COUTY, Louis; TAUNAY, Luiz Goffredo de Escragnolle; TELLES, Augusto Carlos da Silva. Propaganda na Europa do mate, do café e da carne seca. 1881 , p. 27. 
três fomentaram o desenvolvimento de uma máquina de secar café, conhecida como Taunay-Telles. Todos esses elogios ao processo mecânico tinha também o fim de introduzir a máquina Taunay-Telles no processo de mecanização que vinha ocorrendo no Brasil.

A missão realizada por Couty, Taunay e Telles, visou inserir o mate, a carne seca no mercado de consumo europeu, tendo como porta de entrada o mercado francês. Desse modo, a Couty coube mobilizar sua rede francesa de cientistas e de autoridades políticas que o levou a mediar novos mercados pela ferramenta científica que lhe era própria. Com efeito, foi ele de ministério em ministério abrir possibilidades de mercado para os produtos brasileiros. Além disso, mediava-se a necessidade de incutir equipamentos mecanizados a fim de melhorar a qualidade do produto final, facilitando a criação de marcas específicas visando à melhora do preço e o aumento do lucro do fazendeiro. Com esses esforços, notamos que a mecanização dos processos agrícolas de fins do século XIX no Brasil era mediada por homens de ciência como Couty, Telles, Taunay, visando a melhor atuação dos produtos nacionais no mercado internacional de produtos agrícolas. Exemplo bem acabado dessa mediação foi a construção da Máquina Taunay-Telles.

\subsection{A Máquina de Secar Café Taunay-Telles, cultura técnico-científica e mediação cultural}

Em seus primeiros passos pela Corte, Louis Couty levava, para uma aula prática, seus alunos da Escola Politécnica, para conhecer "o estabelecimento de máquinas 
para a lavoura dos Srs. Moreira Cunha \& C", a fim de demonstrar os processos de um "secador de café denominado Secador Pneumático”. Na exposição aos alunos, Couty mostrava-se satisfeito e tecia elogios ao inventor da máquina, o Dr. Ferro Cardozo, dizendo que era "muito bem lembrada a aplicação do princípio da física relativo à evaporação rápida dos líquidos, desde que estes se achem em um recinto no qual se possa fazer o vácuo, o dessecamento do café". ${ }^{254}$ O cotidiano da cultura técnico- científica do final do século XIX brasileiro, pode ser apreendido nas sutilezas do percurso de Couty pelas ruas da capital do Império, sobretudo, porque Couty pode ser entendido como um mediador do aparato científico entre o mundo industrializado da Europa e a realidade brasileira, da produção cafeeira, que buscava aprimorar a produção pela modernização agrícola.

Imagina-se um cilindro de folha de flandres, munido de pás dispostas interiormente segundo as suas geratrizes. Esse cilindro acha-se envolvido por um outro de parede dupla, qual circulava uma corrente de vapor de água. Entre esse segundo cilindro e o primeiro, havia uma camada de ar, corpo péssimo condutor de calor como sabemos. Metia-se o café no cilindro interior e imprimia-se a este um movimento de rotação regular: assim tinha-se o café aquecido pela irradiação do calor do vapor de água e revolvido pelas pás. ${ }^{255}$

\footnotetext{
254 Gazeta de Noticias, 14 out. 1879.

255 COUTY, Louis. "Maquina de secar café”. In: O Auxiliador da Indústria Nacional; v. 48; Rio de Janeiro, 1880, p. 203. Louis Couty acompanhou os processos de criação da máquina e no final da obra realizada recebeu dos inventores o convite para escrever um artigo sobre o invento. O artigo é este que saiu publicado no O Auxiliador, órgão de divulgação da Sociedade Auxiliadora da Indústria Nacional, da qual era sócio.
} 
Assim descrevia Louis Couty um invento genuinamente brasileiro do qual tinha orgulho de ter sido "o primeiro a insistir com o Dr. Goffredo de Escragnolle Taunay" que empreendesse na criação de uma máquina de secar café: a Máquina de Secar Café Taunay-Telles. ${ }^{256} \mathrm{O}$ uso de máquinas na produção era uma questão importante para Louis Couty. Vindo da Europa industrial, tinha ele noção da transformação que a introdução de máquinas traria para o aumento da produção e da qualidade dos produtos brasileiros. Estava em questão a modernização agrícola do país. Com isso em mente incentivou seus dois amigos engenheiros a elaborar uma máquina de secar café.

No percurso entre a primeira metade e a segunda metade do século XIX, o ocidente experimentou o poder transformador da ciência aplicada ao trabalho das máquinas. ${ }^{257}$ Os espaços se encurtavam, o mundo era ao mesmo tempo maior e menor com a expansão das ferrovias que transcorriam mundo a fora. Viajava-se por trilhos e embarcações cruzando terras e mares. Atento a isso o ministro da agricultura Manoel Buarque de Macedo resumia o que precisava o Império pelo que acontecia na Europa e nos Estados Unidos: "Não é só de credito, porém, que a lavoura carece, mas de braços, de instrução profissional, e de vias de comunicação, terrestres e fluviais [...]". ${ }^{258}$ Na Europa de Couty, a vida urbana proporcionava

\footnotetext{
256 COUTY, Louis. “Maquina de secar café”, op. cit., 1880, p. 201.

257 RBEIRO, Cláudio M. "A invenção como ofício: as máquinas de preparo e benefício do café no século XIX”. In: Anais do Museu Paulista, São Paulo, v. 14, n. 1, p. 122, jan./jun. 2006.

258 Ministério da Agricultura. Relatório apresentado a Assembleia Geral Legislativa $3^{\text {a }}$ sessão da $17^{\text {a }}$ Legislatura, 1879, p. 40.
} 
novas experimentações. No Brasil, ainda que mais lentamente, as cidades, em relação ao mundo rural, proclamavam finalmente sua vida própria e sua primazia. As plantações eram nas fazendas, mas as decisões sobre seu destino eram feitas nas cidades. ${ }^{259}$

As máquinas desenvolvidas pelos inventores brasileiros trouxeram para a fazenda cafeeira escravista a atualização tecnológica de máquinas agrícolas existentes nos Estados Unidos e Europa e propiciou uma melhoria de qualidade do benefício em grandes quantidades de café. Esse fato tornou possivel não apenas a consolidação do país como maior exportador no mercado internacional, mas permitiu alterações na estrutura produtiva das fazendas escravistas. ${ }^{260}$

A criação da máquina incentivada por Couty se deu pela parceria entre o engenheiro Goffredo Taunay com o também engenheiro Augusto Telles professor na Escola Politécnica do Rio de Janeiro. Realizaram Taunay e Telles

259 Cf. BUARQUE, Sergio. Raizes do Brasil. São Paulo: Companhia das Letras. 2002. BUARQUE, Sergio. "Introdução”. In: DAVATZ, Thomas. Memórias de um colono no Brasil. Belo Horizonte: Itatiaia; São Paulo: Edusp, 1980. Como professor da Escola Politécnica, diretor do Laboratório de Biologia Industrial, diretor do Laboratório de Fisiologia Experimental anexo ao Museu Nacional, Couty tinha a função de averiguar a situação agrícola do país e trazer os resultados e as soluções. Com efeito, seus relatórios oficiais eram divulgados na imprensa e alcançavam outras províncias - quando anexado aos relatórios ministeriais - a fim de servir como conhecimento no aprimoramento da produção agrícola. Nesse contexto notamos uma alteração na produção do saber agrícola, isto é, os relatórios científicos irão substituir os manuais agrícolas na medida em que os fazendeiros deixam as fazendas e passam a viver nas cidades.

260 RBEIRO, Cláudio M. "A invenção como ofício: as máquinas de preparo e benefício do café no século XIX”, op. cit., 2006. 
várias tentativas até chegarem num tipo de máquina que Couty encontrou no Laboratório de Biologia Industrial após chegar de viagem da região sul. Com o primeiro modelo da máquina pronto, os engenheiros realizaram mais de trinta experiências quer "com o café em cereja, quer com o despolpado mucilaginoso, quer com o lavado". ${ }^{261}$ Nessa ação de Louis Couty com os engenheiros Taunay e Telles notamos sua ação de mediador de conhecimentos tecnológicos e científicos no processo de incremento da agricultura brasileira.

As experiências com a nova máquina eram realizadas manualmente, posto que os inventores não dispunham de motor para mover a roda do ventilador. Assim, vistoriavam os trabalhos dos serventes para que não alterasse a produção do vapor. ${ }^{262}$ Após as experiências realizadas, os resultados obtidos com a máquina agradaram a todos. Contudo, questionava Couty, tendo em mente resultados de outros experimentos de secamento artificial, dois pontos que ele considerou capitais:

[...] o café seco por esse modo conservaria as suas qualidades? Não tornaria a ficar úmido e a sua cor igual não começaria a manchar ou a pontear? O aroma aumentaria com o tempo ou modificar-se-ia em sentido contrário, desaparecendo ou tornando-se mesmo desagradável? ${ }^{263}$

O próprio Couty respondia asseverando a qualidade do produto obtido pela Máquina Taunay-Telles. Todavia,

261 COUTY, Louis. “Maquina de secar café”, op. cit., 1880, p. 202-203.

262 Idem, p. 203.

263 Idem, p. 203. 
era preciso saber se uma máquina maior, onde a mão do homem fosse substituida, teria o mesmo resultado. Construiu-se outra máquina, um pouco menor do que a que seria usada em escala industrial, mas "cem vezes maior" que a primeira. As experiências foram repetidas em novas séries e os resultados foram "notáveis". Com isso, puderam notar que os fenômenos estudados na primeira máquina se reproduziam sensivelmente do "mesmo modo na do tipo maior". 264 Já haveria, com isso, grande progresso para a produção cafeeira.

Comparando a regularidade do secamento no terreiro com o secamento proporcionado pela máquina notava-se que "todos os grão passam absolutamente pela mesma série de fenômenos; o que se dá com um, se dá forçosamente com todos". A homogeneidade do processo mecânico era mais interessante quando comparada com o processo manual: "Ora, no terreiro é impossível, por meio do rodo, atingir este resultado”. A ciência e o desenvolvimento técnico de mãos dadas colocavam em segundo plano as atividades manuais. A partir dessas experiências consideradas bem-sucedidas, Couty dava como resolvido "o problema econômico do secamento artificial do café”. 265

O desenvolvimento da Máquina Taunay-Telles se deu num processo relativamente longo, nele notamos o trabalho de Couty na mediação de conhecimentos nessa máquina. Taunay e Telles empreenderam várias viagens com a finalidade de acompanhar a produção de outras

264 Idem, p. 203-204.

265 COUTY, Louis. “Maquina de secar café”, op. cit., 1880, p. 204. 
máquinas. Nesse percurso, como narra Couty, Taunay e Telles foram a Europa a fim de conhecer outras máquinas e os processos de construção por quais passavam. Entraram em contato com inventores conhecidos e foram a Escócia ver o processo de construção da afamada máquina Lidgerwood. ${ }^{266}$

Em um trecho similar a um anúncio de jornal, dizia Couty os predicados do invento: "a máquina Taunay- Telles economiza grande número de braços, é inferior em custo ao terreiro, torna o fazendeiro independente do sol e das variações do tempo etc.". 267

Pronta a máquina era preciso ser vendida para assim, de fato, se ter plena noção dos resultados. O uso de máquinas seria um salto para a substituição da mão de obra escrava e ciente disso Couty não poupou esforços em indicar as qualidades e as vantagens do invento dos amigos indicando números favoráveis à máquina e desfavoráveis ao trabalho do negro escravizado. Além disso, o controle do clima era um fator diferencial na produção, na medida em que fazendo chuva ou não o café estaria seco.

Para atrair compradores da máquina Taunay-Telles, Couty trazia alguns números favoráveis de seu uso. Usando como referência a fazenda Santa Luzia, propriedade do fazendeiro Dr. Braz Nogueira da Gama, dizia que "apenas com dez anos de existência” a produção desse estabelecimento agrícola era de 10 a 15.000 arrobas, "devendo em breve atingir a cifra de 20.000". E só dispõem a fazenda de "uns 75 escravos". Com isso, se estava longe

266 COUTY, Louis. “Maquina de secar café (sistema Taunay-Telles)”. In: O Auxiliador da Indústria Nacional, v. 51, p. 38-39, 1883.

267 Idem, p. 39. 
das grandes fazendas onde era preciso 500 trabalhadores para produzir 40.000 arrobas de café. 268

Por meio desses inventos apontava o cientista francês que a mão de obra tornaria menos cara, mais do que isso, elevaria "o nível do trabalho agrícola no país". Essas máquinas, e toda a engenharia por traz delas, ocupavam função importante no modo de produção brasileiro. Couty e seus amigos tinham em mente que, através da ciência e das técnicas advindas do conhecimento cientifico, o Brasil alcançaria lugar de destaque, visto que possuía grandiosa riqueza disposta a ser utilizada. Nesse cenário de máquinas, inventos, laboratórios, experimentos, os produtos da economia imperial seriam transformados e, melhorados, ao sabor do mercado europeu.

Numa fala aparentemente de si e dos seus, de suas ações e dos outros cientistas, mostrava a necessidade de aliar conhecimento técnico-científico à dinâmica da produção agrícola nacional.

[...] Que serviço não prestaria quem apresentasse uma série de instrumentos aratórios adaptados aos diferentes solos do Brasil e capazes de substituir o negro e a sua enxada; que serviço não prestaria quem demonstrasse a todos os fazendeiros que talvez pudessem, pela poda e sistema de plantio mais perfeito, duplicar a sua colheita, ou, em todo caso, torná-la melhor e aumentar a duração dos cafezais! Assim também quanto ao emprego de máquinas para o secamento e benefício do café, quanto à abertura de vias de comunicação, e muitas outras coisas mais. ${ }^{269}$

\footnotetext{
268 Idem, p. 35.

269 COUTY, Louis. “Maquina de secar café (sistema Taunay-Telles)”, op. cit., 1883, p. 36.
} 
Crítico do trabalho do escravo no processo do secamento do café, que, para Couty, sempre estava sujeito a perdas diante da ação atmosférica, indicava as potencialidades da máquina de secar café e, ao fazendeiro, aconselhava o uso, podendo agora "pelo emprego de máquinas, não fazer intervir tão diretamente a mão de obra e o escravo". Com isso, poderia utilizar os escravos dispensados do secamento em outras atividades. A máquina garantiria o menor uso de mão de obra, de força, na produção do café e Couty supervaloriza as comparações, posto que "um único homem poderá secar a colheita toda e ainda assim vigiar o bom andamento dos mecanismos já existentes”. Era preciso trabalhar diante das ameaças de crise que a transformação do trabalho poderia produzir no Brasil. Cuidar quanto antes dessa ameaça e "preencher o vazio que se vai dar" era ordem imperativa no momento. ${ }^{270}$ Essa crise que preenchia o enunciado das questões pontuadas por Couty deveria ser suprimida diversificando as potencialidades econômicas do país através da inserção de novos produtos no mercado internacional.

O incremento pleno desses produtos só aconteceria com a transformação do trabalho: "substituição do escravo pela máquina, ou ainda pelo arado e seus motores animados, quando estes instrumentos diversos forem confiados a homens livres, ativos e econômicos, pois disso colherão vantagem, visto serem responsáveis e lutarem para proveito seu". ${ }^{271}$ Esses homens de ciência

${ }^{270}$ COUTY, Louis. “Maquina de secar café”, op. cit., 1880, p. 205-206. 271 Idem, p. 206. 
estavam abrindo as possibilidades que o Brasil tinha a oferecer à mão de obra livre que Couty considerava mais inteligente, ativa, capaz de compor e transformar o tecido social brasileiro dando-lhe qualidades próprias do elemento europeu. Havia um centro civilizador, a Europa que ofereceria a mão de obra e espalharia a civilização onde não houvesse civilização.

Questionando-se sobre a aceitação ou não desse invento, observou que a prática do uso de máquinas de beneficiamento de café foi, aos seus olhos, uma surpresa. Louis Couty acreditava que encontraria meios primitivos de beneficiamento, sempre com o uso da mão de obra direta, algo que considerava pouco produtivo. Contudo, "por toda a parte encontrei máquinas das melhores e mais custosas". 272

\subsection{Apoteose da máquina}

Trocaram-se muitos brindes. Citaremos o do Sr. deputado Taunay à família do nosso ilustre anfitrião, o do engenheiro Taunay à imprensa, respondido pelo Dr. Luiz Castro, do Jornal do Commercio, o Dr. Telles ao Dr. Louis Couty, o deste senhor aos Srs. Fazendeiros, o do Sr. Maximino Serzedello, desta folha e outros. ${ }^{273}$

Só faltou o Imperador, poderia dizer um leitor da Gazeta de Notícias atento aos interesses de D. Pedro II pela ciência. Entretanto, a festa era do comendador Domingos

272 COUTY, Louis. “Maquina de secar café”, op. cit., 1880, p. 204.

273 Gazeta de Noticias, 7 set. 1883. 
Theodoro de Azevedo Junior, proprietário da fazenda Santa Genoveva onde aconteceu a festividade de inauguração da Máquina de Secar Café Taunay-Telles. Foi um "momento esplêndido" exclamou o jornalista da Gazeta de Notícias que acompanhou o evento. Era o progresso: "Estouravam se foguetes, estrugiam a música, os vivas, entre os quais notamos um do dono da casa daquela fazenda aos seus escravos" que ao se referir ao trabalho destes "embargou-lhe a voz". Uma festa plena, até para a escravaria que bem trajada acompanhava a festividade. ${ }^{274}$ O clima era de liberdade, um prato cheio para o francês Couty ampliar seus argumentos contra Schoelcher.

A impressão que trouxeram os excursionistas da alimentação e saúde dos escravos foi a melhor possível. Estavam bem trajados, muito limpos, alguns calçados e até de relógio ao colete. Nas mesas postas embaixo do pomar, bebia-se até champanhe. Gozassem esses entes o favor da liberdade, cujos hinos enchiam os ecos com os sonhos da Marselhesa, e deveras ali habitaria a felicidade. ${ }^{275}$

A máquina recebia a devida atenção que poderiam esperar Taunay, Telles e Couty. As expectativas com o progresso reluziam como os foguetes que estouraram na festa. A máquina já era uma realidade e as qualidades dela enfatizadas:

Assinalar as vantagens que proporciona ao lavrador o secamento do café por este sistema, seria inútil. Basta lembrar que graças à máquina

274 Gazeta de Noticias, 7 set. 1883.

275 Idem. 
Taunay-Telles se acha o fazendeiro superior aos caprichos do tempo; pode remeter ao mercado os seus produtos, no momento mais conveniente, e, sobretudo economiza grande número de braços em uma época em que são tão escassos. ${ }^{276}$

Um grande avanço rumo ao progresso. Uma independência para o fazendeiro que se libertaria em relação "aos caprichos do tempo". A produção não pararia mais com o uso de máquinas. A autonomia da produção proporcionava outra relação com o tempo. O café estaria seco desde que bem processado. Proclamava-se a independência e Louis Couty regozijava-se com a apoteose da máquina.

Essa mediação de conhecimento científico que Louis Couty realizou, proporciona compreendermos a dimensão da transformação acelerada por qual passou a expansão cafeeira em fins do século XIX no Brasil. Houve intensa mudança dos meios de transformar a terra a partir da introdução de máquinas. Era o café demandando não apenas braços para a lavoura, mas saberes a fim de melhorar a produção e a qualidade do precioso fruto. A ciência atuava na expansão cafeeira dimensionando as necessidades, mediando a transformação, por qual passou a economia cafeeira do período aqui estudado.

\subsection{0 problema da moléstia do cafeeiro}

Nem só de êxitos se fez a carreira científica de Louis Couty no Brasil. Um tema a que ele dedicou atenção, a

${ }^{276}$ Idem. [grifo nosso]. 
moléstia do cafeeiro, traria duras críticas da comunidade científica do seu tempo. Sobretudo, de Emílio Goeldi que teceu críticas ao que disse Couty e estabeleceu uma genealogia de uma moléstia que afetava o cafeeiro.

A denominada moléstia do cafeeiro teve seu primeiro foco registrado nas proximidades de São Fidélis ao norte da província do Rio de Janeiro, na fazenda Pureza, na qual a mortalidade dos pés foi tão grande em 1869 que seu proprietário optou pelo abandono da cultura do café.

Do ponto inicial veio o mal se propagando para sudoeste, na zona compreendida entre o rio Paraíba (lado norte) e as serras do Colégio e Magdalena (lado sul), no vale dos dois Rios, na freguesia da Ponte Nova, onde em 1873 e 1874 foram bem notáveis os danos causados à lavoura do café $\left[\ldots . .{ }^{277}\right.$

Em 1878, o antecessor de Louis Couty na Escola Politécnica, o cientista francês Clément Jobert emitiu uma nota científica, Sur une maladie du caféier au Brésil, na qual estudou uma moléstia que assolava a região cafeeira do Rio de Janeiro. Era a moléstia do cafeeiro. O motivo do relatório partiu de um convite feito a ele por um dos principais produtores de café de Cantagalo para que se realizasse estudo de uma doença que se espalhava pelos cafeeiros da região. Segundo Jobert, os pés de café mais atacados eram os de sete a dez anos de idade, especialmente os que se desenvolviam ao longo dos rios, nas

277 GOELDI, Emilio. Relatório sobre a moléstia do cafeeiro na província do Rio de Janeiro. Reeditado por Romero Marinho de Moura. Recife: UFRPE; Fadurpe, 1998, p. 15. (A primeira edição é de 1887) 
áreas sombreadas e húmidas. ${ }^{278}$ Resumia que a moléstia do cafeeiro se encontrava na ação de anguillulas, um tipo de verme.

Em 1879, Louis Couty indicava as necessidades de estudar as moléstias do cafeeiro, "das quais algumas podem ser estudadas experimentalmente por meio do microscópio". ${ }^{279}$ Em 1883, Louis Couty emitiu um relatório no qual entrou novamente na questão da doença do cafeeiro, mas sem muito aprofundar análises.

Em 1881, após visitar a região acometida pela moléstia do cafeeiro, o ministro da agricultura Buarque de Macedo nomeou Guilherme de Schüch, o barão de Capanema, para estudar "o mal que devasta os cafeeiros" da região de São Fidelis e Cantagalo e "indicar qual o remédio e providências precisas para o debelar”. ${ }^{280}$ O Barão de Capanema, engenheiro, geólogo foi um apaixonado pela botânica ${ }^{281}$ e figura importante da elite imperial que circulou por espaços institucionais científicos e técnicos, tendo atuado de forma ativa na implementação de uma cultura técnico-científica no Brasil. ${ }^{282}$ Depois de certo período estudando o mal do café o barão de Capanema emitia suas observações que foram divulgadas pelo Jornal do

278 JOBERT, Clement. Sur une maladie du caféier au Brésil. Compte Rendu.1878, p. 3.

279 COUTY, Louis. "A Cultura do Cafeeiro na Província de São Paulo”, op. cit., 1879 , p. 164.

280 Jornal do Agricultor, ano 3, tomo 5, 1881. O título do artigo que tratou da nomeação de Capanema era "O novo mal do cafeeiro".

281 SÁ, Magali Romero. "O botânico e o mecenas: João Barbosa Rodrigues e a ciência no Brasil na segunda metade do século XIX”. In: História, Ciências, Saúde - Manguinhos, v. 8 (suplemento), p. 899-924, 2001. 282 FIGUEIRÔA, Silvia Fernanda de Mendonça. "Ciência e tecnologia no Brasil Imperial: Guilherme Schüch, Barão de Capanema (1824-1908)”. In: Varia História, Belo Horizonte (MG), v. 21, n. 34, p. 437-455, 2005. 
Agricultor. Concluía o botânico que as causas estavam ligadas ao solo e às condições meteorológicas. Descartava as conclusões de Clément Jobert ao asseverar que "as anguillulas achadas pelo Sr. Jobert, no laboratório de Paris provieram [...] da decomposição dos arbustos que para ali foram encaixotados em estado de umidade".283

Em 1886, a preocupação com o grassar da moléstia do cafeeiro continuava a mobilizar o Estado, a ciência, os proprietários e a imprensa repercutia as ações a fim de que fosse encontrada a solução do mal que afetava o principal produto brasileiro. ${ }^{284}$ Para tanto, o cientista suíço Emílio Goeldi foi incumbido ${ }^{285}$ de percorrer as regiões cafeeiras afetadas por este mal e trazer uma solução que desse cabo a tal problema. Em consequência das análises foi publicado um relatório em que Goeldi aprofunda as investigações científicas sobre a moléstia, bem como nos tipos de solos mais favoráveis a ação dela. Goeldi veio para o Museu Nacional recomendado por Ernst Haeckel, de quem foi assistente em 1882. Contratado em 1885 para o cargo de subdiretor da seção de Zoologia, permaneceu no Museu Nacional até 1890. Em 1894 torna-se diretor do Museu Paraense que levaria seu nome. ${ }^{286}$

\footnotetext{
283 Jornal do Agricultor, ano 5, tomo 9, n. 217, 1883.

$284 \mathrm{O}$ ministério da agricultura aprovou as instruções expedidas pelo diretor do Museu Nacional ao Dr. Emílio Goeldi, subdiretor do mesmo estabelecimento, incumbido por aquele ministério de proceder às mais minuciosas indagações, pelas quais se possa descobrir e debelar a origem do mal que devasta os cafeeiros em extensa região da província do Rio de Janeiro, sobretudo nos municípios de Santa Maria Magdalena, São Fidelis de Cantagalo. Gazeta de Notícias, 23 jul. 1886. 285 Para a realização dessa missão Goeldi recebeu a "gratificação mensal de 200\$, durante a comissão, e abonada a ajuda de custo correspondente à gratificação de um mês”. Gazeta de Notícias, 23 jul. 1886. ${ }^{286}$ GUALTIERI, Regina Cândido Ellero. Evolucionismo no Brasil, op. cit., 2008, p. 61-62.
} 
Em menos de dez anos, de 1878 a 1887, o governo imperial e os próprios fazendeiros solicitaram alguns estudos sobre tal moléstia. Para a missão que realizou com a finalidade de determinar a causa da moléstia do cafeeiro, Emílio Goeldi se valeu de "um laboratório ambulante" na região afetada pela moléstia. Procurou se familiarizar com a sintomatologia da moléstia deixando guiar-se pelas informações de lavradores locais e pelo que via. Fez pesquisas anatômicas e fisiológicas, tanto na planta doente como na planta saudável a fim de comparar melhor a evolução da moléstia, sempre guiado pelo que chamava de "ciência moderna". A ciência moderna exigia, segundo Goeldi, trabalho superior e ao realizar seus estudos sobre a anatomia do café, observava que o estudo do cafeeiro exigia mais trabalho se fosse feito "de acordo com as regras da ciência moderna”. A ciência moderna de Goeldi estava atrelada ao uso de um instrumento, o microscópio. Dizia ele que esta ciência só poderia ser feita "consultando a todo o momento e sobre qualquer questão o meu microscópio”. ${ }^{287}$

Deslocando-se em direção ao foco da moléstia, Goeldi estabeleceu um método analítico de estudo visando "verificar se realmente a moléstia do cafeeiro era idêntica em toda a parte, ou se existia mais de uma", para com isso determinar "do modo mais exato possível, os limites atuais" de ação da doença. Concluiu que a área afetada pela moléstia compreendia 3000 quilômetros

287 GOELDI, Emílio. "Copia do primeiro ofício do comissionado, dirigido ao Ministro da Agricultura”. In: Relatório sobre a moléstia do cafeeiro na província do Rio de Janeiro. Reeditado por Romero Marinho de Moura. Recife: UFRPE; Fadurpe, 1998, p. 107-108. 
quadrados ou 300.000 hectares. A delimitação desse espaço enquadrava "uma parte do vale do baixo rio Paraíba e seus afluentes".288

Com seu microscópio, que "aumentava setecentas vezes o diâmetro do objeto a ele submetido", 289 em mãos, exercendo sua ciência moderna, Goeldi caracterizava que moléstia se manifestava exteriormente, ficando "aos olhos do lavrador" que poderia identificar "um desbotamento de todas as partes exteriores (amarelidão das folhas, cor trigueira das vergônteas), dessecamento e definhamento final do pé inteiro". A partir de conversas com um "lavrador inteligente", notou que a ação da moléstia acometia o cafeeiro de duas formas. Uma forma crônica onde o pé não morre senão meses depois do aparecimento dos primeiros sintomas exteriores, outra forma mais aguda ou fulminante, onde o pé morre de repente em 8 a 15 dias, "sem antes ter apresentado distintamente os sintomas". ${ }^{290}$ Contudo, apesar de considerar inteligente um lavrador, em sua maioria, os fazendeiros, "não sabem dar informação alguma sobre o período em que a moléstia invade certo indivíduo". De modo geral, asseverou Goeldi que os lavradores "só conhecem a moléstia em seu estado final, e só percebem - por experiência própria - quando o pé manifesta todos os sintomas de morte próxima”. Momento este que não há mais nada

288 GOELDI, Emílio. Relatório sobre a moléstia do cafeeiro na província do Rio de Janeiro. Reeditado por Romero Marinho de Moura. Recife: UFRPE; Fadurpe, 1998, p. 18-19.

289 Jornal do Agricultor, ano 8, tomo 16, n. 397; 5 fev. 1887, p. 90.

290 GOELDI, Emilio. Relatório sobre a moléstia do cafeeiro na provincia do Rio de Janeiro, op. cit., 1998, p. 25. [grifo no original] 
para ser feito, momento que os fazendeiros chamam de doente o pé de café "que não é mais doente", que "é um agonizante, que nenhum poder é capaz de arrancar ao seu fatal destino". 291

O caminho para a descoberta da doença do cafeeiro foi difícil, nesse percurso Goeldi oferta bons créditos ao trabalho de Jobert. O cientista suiço caracterizou a doença do cafeeiro como sendo "essencialmente uma moléstia das raízes”. Desse modo, Goeldi chegava à conclusão que a origem da causa da moléstia se encontrava em um verme causador das nodosidades na raiz da planta afetada, sendo que este verme se estabelecia desde a mais tenra idade na planta. Classificou esse verme e deu- the o nome de meloidogyne exigua. ${ }^{292}$

Na missão designada, Goeldi procurou diferenciar a moléstia do café que ele apresenta no relatório de outras que pudessem gerar confusão, mostrando que a moléstia do "bicho do café" não é a mesma que ele trata no relatório. ${ }^{293}$ Havia muita confusão quanto à origem da causa da moléstia que Goeldi identificou em 1887. Quanto a isso, menciona um diálogo interessante com o Barão de Capanema. Nesse diálogo, Capanema acreditava que a origem da moléstia se encontrava na seca. Contudo, Goeldi observou, a partir de suas análises, que não poderia ser a seca a causa imediata da moléstia do cafeeiro, mas sim o nematóide encontrado na raiz do cafeeiro. Se Goeldi não tivesse chegado às conclusões que indicasse que a origem da moléstia se encontrava nas raízes do

291 Idem, p. 50.

292 GOELDI, Emílio, op. cit., 1998, p. 28, 39, 51, 68.

293 GOELDI, Emilio, op. cit., 1998, p. 77. 
cafeeiro, como ele mesmo diz, "teria optado pela opinião” do Barão de Capanema. Dizia Goeldi a respeito das observações do Barão de Capanema,

[...] Não nego a existência de um nexo causal, ligando a seca ao parasita do reino animal. Mas este nexo causal seria justamente o inverso do que S. Ex. [Barão de Capanema] pensa. [...] Para precisar a minha própria opinião relativamente à de S. Ex., direi que a seca e a chuva desempenha certo papel na moléstia do cafeeiro - sob a forma de fatores subordinados, de condições exteriores de existência do nematoide do cafeeiro, que é a causa primaria da moléstia em questão. ${ }^{294}$

É interessante sublinhar que as relações entre os cientistas brasileiros e estrangeiros nas décadas de 1870 e 1880 foram marcadas por intensos e acalorados debates. Nesse cenário, o reconhecimento mencionado que Goeldi faz a Capanema é um reconhecimento da obra de um não reconhecido. O conhecimento que Capanema tinha da botânica não favoreceu seu reconhecimento pela comunidade científica nacional, especialmente por parte do diretor geral do Museu Nacional, o Dr. Ladislau Netto, seu grande desafeto. Em desabafo dizia Capanema que ao tentar dar impulso ao estudo da botânica na própria terra, esbarrava num "terrivel veto, capaz de extinguir a mais robusta ciência e o mais fogoso entusiasmo; magna auctoritate me foi declarado que eu era engenheiro e não botânico!". ${ }^{295}$ Ainda que jovem, Goeldi possuía notório

294 GOELDI, Emilio, op. cit., 1998, p. 83.

295 SÁ, Magali Romero. "O botânico e o mecenas: João Barbosa Rodrigues e a ciência no Brasil na segunda metade do século XIX". In: História, Ciências, Saúde-Manguinhos, v. 8 (suplemento), p. 899-924, 2001. 
conhecimento da ciência e estava vinculado ao Museu Nacional naquele momento como um dos subdiretores.

A origem da moléstia do cafeeiro e sua possivel solução acompanhou a expansão cafeeira do centro-sul por cerca de vinte anos até em 1887 quando Emílio Goeldi define a origem da moléstia. Nesse percurso de decifração da moléstia Couty teceu algumas observações, mas que não tiveram o mesmo resultado científico de Jobert e Goeldi. Quanto a isso, dizia Goeldi que Jobert foi "o único observador que realmente reconheceu" antes dele "as relações de um verme nematoide para com a moléstia do cafeeiro", mas que Jobert não deu "informação alguma sobre a zoologia do animal” em seu estudo da moléstia. Estudo este que para Goeldi carecia de mais informações, posto que nem fora "acompanhado de ilustrações quaisquer, sobre o assunto [...]". 296

Já em relação às observações de Couty sobre a moléstia, dizia Goeldi que em

seu extenso trabalho sobre as condições da cultura do café no Brasil, o Dr. L. Couty toca de passagem na questão da moléstia do cafeeiro (1883, p. 23). O modo por que ele o faz revela-nos logo que o falecido autor apenas conhecia a dita moléstia por vagas descrições e não por inspeção própria na localidade afetada. A sua opinião pode ser resumida do modo seguinte: 'Na província do Rio de Janeiro a camada de terra arável está geralmente reduzida a 50 centímetros ou menos ainda; abaixo se encontra, como base, argilas de natureza muito compacta e rochas muito pouco decompostas. Nestas condições a raiz mestra

296 GOELDI, Emilio, op. cit., 1998, p. 59. 
dificilmente encontrará passagem; as raizes são, pois, forçadas a um desenvolvimento horizontal, quase à flor da terra, ficando assim expostas ao ardente sol tropical, ao dessecamento. ${ }^{297}$

E cita outro trecho de Couty.

Citarei textualmente o trecho seguinte (1883, p. 24): 'Esta suspensão (forçada, de todo o arbusto), sendo frequentemente devido a uma causa geral, o estado do solo, poderá produzir-se ao mesmo tempo em uma região inteira, em uma plantação inteira; ela simula então uma verdadeira moléstia, e o mal estado das raízes, facilitando várias produções parasitárias, esta doença poderá ser encarada como uma epidemia vegetal por aqueles que confundem os efeitos e as causas e que esquecem a bem conhecida resistência do cafeeiro a insetos nocivos a muitas outras plantas vizinhas e muitas vezes contíguas'. 298

Após expor essa opinião que Goeldi transcreveu para seu contra-argumento, Couty, em seu relatório, dizia que "a opinião geral entre os fazendeiros de Cantagalo atribui a um vício no desenvolvimento [das plantas] devido à seca ou a outras causas complexas" as mortes súbitas que acometem os pés de café. Em seguida concluía suas observações sobre a moléstia dizendo que esta opinião era compartilhada "por um homem competente" o Barão de Capanema. ${ }^{299}$ Em relação às conclusões de

\footnotetext{
297 Idem, p. 83.

298 Idem, p. 83-84

299 COUTY, Louis. Étude de biologie industrielle sur le café, op. cit., 1883, p. 24. Nesse cenário de definição da moléstia, o barão de Capanema aparece como uma figura interessante ofertando seus conhecimentos
} 
Couty, o cientista suíço dizia que "não podemos atribuir grande valor a este ensaio de explicação, feito de levante", posto que Couty teria confundido fenômenos secundários com um fenômeno primário. ${ }^{300}$

Louis Couty atribuiu às condições do solo a possibilidade de simular uma moléstia que, auxiliada ao mal estado das raízes pelo dessecamento, facilitaria "várias produções parasitárias”. Couty entendeu que a moléstia teria como causa as condições do solo, que ao expor com mais facilidade as raízes abriria condições para a ação dos parasitas e, que, diante disso haveria uma confusão entre efeitos e causas. Estava nesse aspecto a inversão suscitada que Goeldi assinalou na tese de Couty. Enquanto que para Couty a causa se encontrava nas condições do solo, para Goeldi a causa estava no verme nematoide.

O percurso de Couty, de Goeldi, de Jobert e de outros cientistas que realizaram missões científicas nas áreas de cultivo do café, por exemplo, era o de identificar, diferenciar o problema e trazer uma possível solução. Contudo, nesse percurso de decifração do mal do café, Goeldi estabelece uma história a partir das críticas que fomentou ao trabalho de Louis Couty. Ao criticar Couty, Goeldi estabelecia uma hierarquia dos cientistas que subsidiaram conhecimento em prol da solução do mal do cafeeiro, colocando se como descobridor do problema e, portanto, referência na questão. Ao refutar o que pensou

primeiramente a Couty e ulteriormente a Goeldi. Capanema, pelas querelas que teve com alguns membros da comunidade cientifica brasileira, pode ser entendido como uma figura não estabelecida, paralela, mas que subsidiou saberes, à comunidade científica.

300 GOELDI, Emilio, op. cit., 1998, p. 84. 
Couty, Goeldi estava refutando as ideias de um cientista que obteve notório respeito em vida, sobretudo em seu campo de ação, onde foi possuidor de um capital científco que lhe dava autonomia de ação. ${ }^{301}$

Apesar de se opor às considerações de Couty, Goeldi não deixa de ter conclusão semelhante a respeito da ação da moléstia do cafeeiro no aspecto da composição do solo e fazia isso comparando o solo paulista com o solo fluminense:

Espessura maior da camada de terra vegetal, ausência de areia misturada com a argila, um húmus muito fértil - eis os três fatores que principalmente farão triunfar a província de São Paulo. Se a moléstia do cafeeiro chegasse até lá, o terreno não arenoso provavelmente não lhe conviria e ela se extinguiria por si mesma. ${ }^{302}$

Nessa comparação entre as províncias do Rio de Janeiro e São Paulo, Goeldi asseverou que a província de São Paulo sairia vencedora no aspecto cultura do café e condições do solo, posto que "São Paulo apresenta condições geológicas muito melhores para a cultura do café”. 303 Assim, num terreno arenoso como o da região da moléstia, a locomoção do nematoide seria facilitada e por isso seu habitat preferido. Contudo, dizia ele que: "As condições do terreno da província do Rio de Janeiro favorecem

\footnotetext{
301 Para uma compreensão da constituição dos campos científicos Cf. BOURDIEU, Pierre. Os usos sociais da ciência: por uma sociologia clínica do campo científico. Tradução de Denice Barbara Catani. São Paulo: Unesp, 2004.

302 GOELDI, Emílio, op. cit., p. 84-85.

303 Idem, p. 84.
} 
em geral a moléstia do cafeeiro, mas não há argumento algum valioso para considerá-las como causa”. Em resumo, Goeldi dizia que sua opinião sobre a moléstia do cafeeiro é "a mesma que foi dada pelo Sr. C. Jobert em 1879", ou seja, a de que o agente causador da moléstia era um verme nematoide. ${ }^{304}$ Goeldi se entendia como o último na escala de estudiosos da moléstia do café, sendo que ele ocuparia o papel de descobridor da causa, Couty ocuparia um papel terciário no processo e Jobert teria sido

o primeiro e o único de meus predecessores que procurou a solução da questão da moléstia do cafeeiro no campo biológico, e reconheceu desde o princípio a necessidade de recorrer ao microscópio como o mais importante auxiliar. A sua nota revela também o biologista de profissão, conhecedor de sua matéria, e sabendo manejar o instrumento a que a ciência moderna deve tantas e tão valiosas conquistas. ${ }^{305}$

É interessante notar que Goeldi sublinhou a ação científica de Jobert pelo uso que este fez do microscópio para analisar o problema, ou seja, praticou o que ele chamava de ciência moderna. Contudo, não fez referência à menção que Couty fez quanto à necessidade de observar a moléstia do cafeeiro pelo microscópio também. Com efeito, há nesse percurso da expansão cafeeira e da moléstia do cafeeiro uma trajetória, a trajetória da ciência que sobressaiu e estabeleceu a diagnose e os modos

304 GOELDI, Emílio, op. cit., 1998, p. 85. [grifo no original].

305 Idem, p. 85. 
de prevenir o grassar do problema. Com isso, Clément Jobert, Barão de Capanema, Louis Couty e Emílio Goeldi cumpriram função estratégia no desenlace desse problema que afetava a economia cafeeira no final do século XIX. Todo esse empenho é documento da, ainda que de pouca monta, ${ }^{306}$ ação do saber científico no processo de expansão cafeeira.

Como medida profilática para conter o avanço da moléstia, Goeldi sugeria alteração no modo da produção do café, especialmente na província do Rio de Janeiro que possuí um solo arenoso. Estava ele certo de que a mudança na produção a partir do que chamou de "cultura racional" seria acompanhada de efeitos benéficos. Com efeito, estava convencido de que, "plantando menos - porém melhor -, a produção de café poderá ser enormemente aumentada”. A produção do café em pequena propriedade "aumentaria em grande escala", e mais próximos da produção, os pequenos proprietários plantariam pouco, "mas com cuidado". Além disso, classificou como funesto o "sistema extensivo da cultura

306 A respeito da parca oferta de investimentos científicos conciliada com a ignorância dos fazendeiros, um observador do Jornal do Agricultor resumia: "Os estudos de anatomia e fisiologia vegetal, para surpreender os fenômenos que opera nas plantas a moléstia que as invade é coisa mínima, insignificante mesmo, não só para os nossos agricultores, em geral ignorantes do muito que a ciência tem em si para minorar thes os males e as calamidades que os assoberba, como por aqueles a quem incumbe a pública gestão dos negócios atinentes à agricultura”. A crítica era direcionada ao Ministério da Agricultura que segundo o autor: "Procurai entre o pessoal do Ministério da Agricultura um agrônomo, um veterinário, um engenheiro agrícola, um professor de biologia, mesmo um prático de qualquer ramo da ciência agrícola e não encontrareis", ano 8, tomo 16, n. 397, p. 89, 5 fev. 1887. 
do cafeeiro". Quanto a isso, enfatizava ser este o grande causador da destruição das florestas que, "segundo os resultados da climatologia moderna, é o regulador por excelência das condições pluviométricas". 307

$\mathrm{Na}$ emissão de parte de suas observações, Goeldi estava disposto a provar que "para o combate eficaz contra a praga”, seria tempo perdido, mais do que isso, seria "utopia esperar" por um "remédio na acepção que the imprime a fantasia popular, isto é, capaz de tornar instantaneamente são um pé de café em adiantado estado mórbido”. O remédio para a moléstia se encontrava no ato de conhecer sua natureza e evitar todos os fatores que favorecem o seu desenvolvimento e dispersão. Assim, e para elaborar tal argumento Goeldi citava o professor M. Ward, que dizia que nenhum "animal nocivo à agricultura pode ser combatido com sucesso sem o profundo conhecimento dos seus costumes e transformações”. Era preciso conhecer, e ao conhecer "as primeiras fases da moléstia, antes de se manifestarem os terriveis estragos" pôr em prática um "rigoroso isolamento de qualquer foco" para pôr "obstáculo a maiores proporções da epidemia”. 308

Emílio Goeldi apontava o caráter epidêmico da moléstia, enfatizava que apenas alguém "insuficientemente orientado" poderia pensar o contrário. Para em seguida dizer que teria sido, "sobretudo, o Sr. Louis Couty quem negou o caráter epidêmico da moléstia”. E concluir que a "ciência moderna, em semelhante questão, não se contenta com retórica" ${ }^{309} \mathrm{Com}$ isso, Emílio Goeldi não considerou as

307 GOELDI, Emilio, op. cit., 1998, p. 87, 95, 82. [grifo no original].

308 Idem, p. 112-113.

309 Idem, p. 57-58. 
observações de Louis Couty resultantes do que ele chamou de ciência moderna, ou seja, que não havia fatos no argumento - "Res non verba" dizia ele - de Couty no aspecto da moléstia do cafeeiro. Apesar de indicar a necessidade do uso do microscópio, fato ignorado por Goeldi, Couty apenas esboçou estudos sobre a moléstia do cafeeiro, ficando mais com as observações dos fazendeiros com quem conversou e com as informações do barão de Capanema.

A comunicação que Goeldi estabeleceu com seus colegas de microscópio é interessante, posto que manifesta a intensa comunicação no campo da ciência, mostrando mais ainda que cada país (especialmente os países europeus) se destacavam nos mais variados aspectos do desenvolvimento científico. No caso de Goeldi, suas comunicações se atrelavam à via da botânica e da fitopatologia.

[...] entrei em correspondência com especialistas conhecidos, como altamente competentes em botânica e fitopatologia. Estabeleceu-se esta correspondência em larga escala, e, na hora que escrevo estas linhas, posso afirmar que nos círculos científicos achou este meu relatório provisório ótima aceitação, e que, entre os meus colaboradores na questão, figuram autoridades de reputação universal. ${ }^{310}$

Mobilizou Goeldi uma rede de saberes aos quais estava mais próximo, da mesma forma fez Louis Couty

310 GOELDI, Emílio. "Copia do primeiro ofício do comissionado, dirigido ao Ministro da Agricultura”. In: Relatório sobre a moléstia do cafeeiro na província do Rio de Janeiro. Reeditado por Romero Marinho de Moura. Recife: UFRPE; Fadurpe, 1998, p. 108. 
com sua rede cientifica francesa. Ambos os cientistas realizaram essa mobilização de saberes com a finalidade de solucionar os problemas referentes às economias do Império. Enquanto Louis Couty citava Paul Broca, Morin, Claude Bernard, Vulpian; Emilio Goeldi citava Oscar Schmidt e L. Oerley.

E foi a partir dessa rede de sociabilidade científica que Goeldi mobilizou conhecimento para defender seus argumento e demostrar, segundo ele, a insustentabilidade dos argumentos de Couty. Para tanto:

A insuficiência da explicação do Sr. Couty foi, aliás, ultimamente demonstrada experimentalmente pelo Dr. Ph. A. Caire. Ele tomou jovens plântulas, da variedade Maragogipe, anteriormente tratadas com todo o cuidado (regadas, estrumadas e cultivadas em pura terra vegetal) e transplantou a para o limite de uma roça nova, fresca e sombreada, a poucos passos da floresta virgem; ele fez abrir uma grande e espaçosa cova para cada pé, e ainda, por meio de uma barra de ferro, um tubo profundo no subsolo para a raiz mestra. Conquanto o lugar fosse dos mais favoráveis, e o tratamento excepcional, já tive ocasião de dizer que a porcentagem da mortalidade de 40 pés 'Maragogipe', assim tratados não foi menor do que a existente entre pés não favorecidos por tais preparativos. ${ }^{311}$

Havia um movimento de saberes entre a constituição dos relatórios científicos e seu auxílio no manejo do solo e do cuidado em selecionar as mudas (do café) e as sementes para melhorar a produção e, também, debelar

311 GOELDI, Emílio, op. cit., 1998, p. 84. 
as moléstias. Do cientista ao fazendeiro, notamos a trajetória dos saberes, o diálogo que é estabelecido entre o que se fazia nos laboratórios do Brasil com o que se fazia nos laboratórios da Europa e os meios de sua aplicação na lavoura. No cenário internacional da dinâmica do comércio e consumo de café a ciência ocupava um papel de aprimorar a produção, apontar os erros e direcionar o produtor a obter maiores acertos, qualidades e lucros. Os relatórios de Louis Couty, Clément Jobert, Emílio Goeldi e de outros cientistas, portanto, são documentos essenciais da ação da ciência no processo de expansão cafeeira. A disputa que Goeldi estabeleceu com Couty demonstra uma disputa interna na construção do saber científico - no caso a solução para a moléstia do cafeeiro. O modo como Goeldi entendeu ser o melhor método de resolver o problema, isto é, o uso do microscópio, o colocava no que o mesmo chamou de ciência moderna, mas também colocava Couty numa ciência que não era capaz de resolver por todo o problema, sendo uma ciência antiga. Todavia, nessa disputa, Goeldi ignorou o relatório que Couty dizia que o uso do microscópio era uma maneira de resolver o problema. Refutar um cientista reconhecido como Couty seria um meio de trazer para si um acúmulo de capital científico. Sobretudo, ao solucionar a questão pelo que chamou de ciência moderna, sagrava seu poder de especialista. Desconstruindo a construção do campo de Goeldi pela crítica estabelecida a Couty, notamos nos fatos a força de atuação que teve Couty, posto que ao ter suas ideias refutadas por alguém que as superou, este alguém se equipara ou mesmo superava o capital científico de seu oponente. 


\subsection{O Plus Ultra do café 312}

Plus ultra! Não ficou alegre, ficou preocupado, cogitativo; alguma coisa lhe dizia que a teoria nova tinha, em si mesma, outra novíssima teoria. ${ }^{313}$

Machado de Assis nos anos 1870 e, especialmente, 1880 tinha diante de si um contexto repleto do enunciado científico e não perdeu a oportunidade de perfilar, em sua literatura, os deslizes e excessos cometidos por aqueles homens de ciência que no afã de ir mais além, num horizonte de expectativa alucinado, cometiam exagerações que poderiam pôr em questão uma inquestionável autoridade no assunto. No assunto café, Couty já era um homem reconhecido e afamado.

As experiências a que se procedeu no laboratório experimental do Museu Nacional, acabam de demonstrar que o café, ao passo que já não dá grandes lucros aos fazendeiros, é causa de grandes despesas no organismo, ao qual reduz até a inanição. ${ }^{314}$

A Gazeta de Notícias reproduzia e comentava os resultados das experiências sobre o café que Couty e sua

\footnotetext{
312 Plus ultra é uma expressão latina que geralmente é citada como nec plus ultra, ou seja, não mais além. Retiramos esta referência da literatura de Machado de Assis, bem como das notas ao livro O alienista, realizada por Hélio Guimarães. No caso, Machado de Assis coloca plus ultra, ou seja, mais além. Assim usamos com o significado de mais além para indicar o extremo limite que pode chegar uma ciência. Cf. ASSIS, Machado. O alienista. Introdução. GLEDSON, John; Notas. GUIMARÃES. São Paulo: Penguin Classics Companhia das Letras, 2014, p. 82.

313 ASSIS, Machado. O alienista, op. cit., 2014, p. 85.

314 Gazeta de Notícias, 19 out. 1882.
} 
equipe realizaram no Laboratório de Fisiologia. O café passava por uma crise, crise que fez o próprio Couty percorrer as fazendas produtoras de café para entender se tal crise poderia ter suas origens no modo de produção das fazendas. E a ciência que vinha para salvar, poderia complicar o futuro do precioso fruto. Decididamente "anda muito por baixo o café" dizia a folha. ${ }^{315}$

Sob a supervisão de Louis Couty, sua equipe realizou uma série de estudos sobre a fisiologia do café e chegava ao resultado de que o café não seria um alimento de poupança para o organismo, mas um alimento de consumo, que ao invés de dar energia, as consumia. Assim, ironizava a folha: "De sorte que tal substância, que passava por ser um alimento de poupança, um contribuinte, não é mais do que um grande consumidor, uma espécie de pensionista aposentado do tesouro nacional".316

No comunicado ao ministro da agricultura, Louis Couty demonstrava o passo a passo da experiência e seu valor científico, que segundo ele só seria reconhecido no futuro. Para tanto, tomou-se "cães vigorosos, no estado normal, pesando-os, e determinando a média de consumo de carne de vaca administrada como única alimentação e submetendo-os à infusão do café”. Posteriormente, repetiam-se os procedimentos. Os animais estavam cuidadosamente isolados para não consumir outro alimento, senão os específicos para a pesquisa. Obtinham-se alguns resultados: 1) "os cães, aos quais só se permite a ingestão de angu ou toucinho, morrem inanidos no fim de

315 Idem.

316 Idem. 
um tempo variável, de 25 a 35 dias, segundo as observações dos Srs. Guimarães e Raposo"; 2) "os cães aos quais se nutre com estes mesmos alimentos associados ao café morrem muito mais rapidamente, de 14 a 20 dias, e perdem mais de seus pesos". No caso, o café, ao invés de aumentar, como se esperava, o consumo dos alimentos, torna mais ativa a despesa fisiológica. Chegava-se a conclusão de que o "uso do café apressou, pois, a inanição e a morte dos animais, tornando mais rápido e intenso o emagrecimento, bem como os diversos processos químicos de consumo interno que o acompanham" ${ }^{317}$

Couty notava que havia uma ideia preconcebida que considerava o café como um alimento de poupança, ou seja, que "diminuem a quantidade de matéria despendida pelo funcionamento orgânico". Contudo, continuava ele a asseverar que "ninguém fez experiências completas para verificar" esse fato. A ilação que chegava era a de que o café seria "um alimento de despesa" que "aumenta a quantidade do alimento consumido" e a partir da observação nos cães nota-se que "apressa os fenômenos de inanição".

Para embasar uma defesa das conclusões suas e de seus auxiliares, nota que o trabalho realizado pelos doutores Guimarães e Raposo se liga ao que ele e d'Arsonval apresentaram sobre "a diminuição dos gases do sangue e das combustões carbonadas pelo mate”. E assim, "poder-se-ia já tentar uma explicação nova da ação do café, que conciliaria todos os fatos, antigos e novos". Fazendo um vaticínio sobre tal trabalho dizia que será "daqui a 100 anos, como hoje, a base dos estudos futuros sobre este

317 Idem. 
gênero de alimentos, porque é fundado sobre observações precisas e completas".

Elogia os trabalhos de seus auxiliares, não poupa elogios à disposição que ambos tiveram no estudo e assim "chegaram a um conjunto de fatos, que poderão ser completados, mas que, na minha opinião, nenhuma objeção permitem ao crítico". E conclui a nota observando que o "Laboratório de Fisiologia, anexo ao museu do Rio de Janeiro, tem o direito de orgulhar-se deste trabalho, que será, certamente, notado na Europa, quando os resultados forem publicados, por minha conta, no Comptes Rendus e nos archivos de physiologia". 318

Apesar da empolgação de Louis Couty com o trabalho realizado por seus auxiliares sob sua supervisão, a recepção desta notícia não caiu bem na imprensa e motivou uma série de respostas que questionavam tais experimentos. Transformava-se Couty, sua sabedoria científica tinha ido além, mais além, via sua autoridade no assunto turvar e ser questionada. Ebuliu na imprensa uma série de intervenções e um longo debate se estabeleceu.

De fruto precioso, de adorável grão, já não tinha mais nada o café: "Já não são só os preços no mercado que o rebaixam até a mais insignificante posição; também as experiências da ciência vêm juntar a sua palavra, no bárbaro intuito de desmoralizá-lo, de rebaixá-lo, de reduzi-lo a zero, a menos de zero". ${ }^{319}$

\footnotetext{
318 Gazeta de Notícias, 19 out. 1882. É importante observar que era hábito da imprensa divulgar os relatórios científicos, com a finalidade de vulgarizar o conhecimento. E bem por isso, encontramos muitos relatórios de Couty na imprensa, especialmente na Gazeta de Notícias e Jornal do Commercio.

319 Gazeta de Noticias, 19 out. 1882.
} 
Poucos dias depois dos novos resultados de Couty sobre o café, a Gazeta de Notícias, tratando da Exposição do Café, contrapunha o que vinha do Museu Nacional com o que saia do Clube da Lavoura, a organização responsável pela referida exposição. Nesses termos dizia a folha que:

Por sua parte, o Sr. Dr. Couty demonstrava que o café era um alimento de despesa e não de poupança, para o organismo - afirmando no dia seguinte, é verdade, que, quando se gasta ou se despende, ganha-se ou adquire-se na mesma proporção, porque... nemo dat quod non habet, e quem muito gasta muito vive, opinião esta que in limine rejeitam os economistas, mesmo alguns higienistas. ${ }^{320}$

Por outro lado:

O Centro da Lavoura e Comércio, também com umas tantas experiências realizadas no seu laboratório comercial, demonstrava por seu lado, que o café era realmente um produto que dava prejuízo - quando malcuidado, e, entretanto, de grande lucro, quando sujeito a um preparo e beneficiamento condignos com o que hoje se conhece, relativamente à lavoura do adorável grão. ${ }^{321}$

Como resultado do embate entre ciência e economia concluía a folha, enfatizando o sucesso da Exposição do Café, que a considerar o público presente manifestava-se em favor de "uma xícara de café bem preparado e servido em boa porcelana de Sèvres". 322

320 Gazeta de Notícias, 29 out. 1882.

321 Idem.

322 Idem. 
Em dezembro de 1882, Louis Couty solicitava espaço na Revista Commercial para contrapor uma publicação de um autor anônimo que questionava suas conclusões sobre o café. Tendo seu pedido negado, Couty recorreu espaço na folha de inspiração francesa que posteriormente seria redator: Le Messager du Brésil. Por sua vez, a Gazeta de Notícias preenchia seu espaço com a querela de Couty:

Peço-vos o obsequio de publicar a carta seguinte, que o redator da Revista Commercial não quis inserir em seu jornal: e aos meus compatriotas peço também para que sejam juízes em uma questão que da minha parte não terá andamento e que não deveria ter origem, por tal forma, entre franceses, em um país estrangeiro. ${ }^{323}$

Nessa contenda, Couty lamentava a negativa de seu compatriota diretor da Revista Comercial e Maritima de não ceder espaço para contrapor as acusações de um anônimo. Na carta publicada no Le Messager do Brésil, Couty lamentava as publicações anônimas daquele que chamou de "confrade desleal", de "médico insolente", que havia achado na Revista Comercial e Maritima um "asilo para covardes alusões pessoais". A essa altura Couty presumia quem seria tal autor anônimo que o teria caluniado. E se defendia dizendo nunca ter dito que "o café fosse um veneno para o homem na proporção das doses que este o consome; nunca escrevi, como se

323 Gazeta de Notícias, 25 dez. 1882. Utilizamos para evidenciar o debate, que teve como causa as questões do café e que posteriormente ganhou outros contornos, as reproduções que a Gazeta de Noticias fez, posto que era esta folha um veículo de grande divulgação e grande alcance. 
pretendeu fazer acreditar, que o mate era um alimento de economia: tudo isto é de valor insignificante". Adiante no texto, Couty defendia seus auxiliares a quem chamou de "trabalhadores novos". 324

Enfim, meus discípulos, menos do que eu ainda, não podem ser responsáveis pelas faltas científicas dos que querem acusar juízes sem competência. O tempo se encarregará de mostrar onde está a verdade; e aqueles que no Brasil pensam e trabalham, saberão fazer justiça a quem a merecer, como já me fizeram, além do que eu podia desejar. ${ }^{325}$

Couty se defende e para tanto, se apoia em uma comunidade francesa que estaria, segundo ele, do seu lado na questão. Dizia que a tristeza que experimentava, experimentavam com ele "todos os franceses ciosos de sua dignidade e da dignidade da colônia”. Como dois franceses em um país diferente poderiam não se dar bem e não zelar um pelo outro? Talvez tenha sido esse o mote da motivação de Couty. Por isso, ele conclama toda uma comunidade francesa que estaria do seu lado. E concluía: "Vós bem sabeis, Sr. diretor: eu havia dado todo meu apoio ao vosso jornal, como a todas as obras que tivessem uma utilidade franco-brasileira. Lamento ver desviado o fim que eu imaginaria. Entretanto, aguardo vossa conduta". 326

Sem tardar, a resposta do diretor da Revista Comercial e Marítima chegava com o sugestivo título: "Questão

324 Gazeta de Notícias, 25 dez. 1882.

325 Idem.

326 Idem. 
do café" ${ }^{327} \mathrm{Na}$ resposta, Morel (o diretor da revista) lamentava o fato de Couty clamar por um julgamento patriótico a respeito de uma questão de menor monta a qual classificou de incidente. Classificou também de "inexata" a recusa de publicação da carta de Couty na Revista Comercial e Maritima.

Nesse meio tempo, Morel revela quem era aquele que Couty chamou de "médico insolente". Era o Dr. Fort. Em resposta ao texto de Couty, Fort retoma a questão do café. Fazendo referência ao experimento do café, dizia o Dr. Fort sobre o Dr. Couty:

Declarou [o Dr. Couty] que o café produz desarranjos no organismo e que é um líquido nocivo à saúde. Sustentou que o homem não difere do cão e que o café mata os cães: [?] todos concluem, que, se o café é um veneno para o cão, deve ser igualmente para o homem. Pronunciou-se contra os interesses do Brasil onde veio hospedar-se e obter uma posição, como talvez não alcançaria em seu país. ${ }^{328}$

Nessa carta resposta, o Dr. Fort não mediu palavras para desconsiderar os trabalhos de Couty. Nesse sentido, Couty seria para Fort "um fisiologista dos mais elementares", sem ter publicado trabalho útil na seara da fisiologia. Para provar que os resultados de Couty estavam errados, eliminou os cães das investigações "fazendo as experiências em minha própria pessoa”. Reunia em si a teoria e a prática. Diante dos resultados obtidos percebeu

327 Gazeta de Notícias, 26 dez. 1882.

328 Gazeta de Notícias, 30 dez. 1882. 
que "o café, longe de ser um líquido prejudicial à saúde, é uma excelente bebida”, que, além disso, produzia uma ação salutar sobre o organismo "excitando ligeiramente o sistema nervoso". Segundo Fort seus experimentos teriam sido bem acolhidos entre os brasileiros "e o fato é tão real que o café teve uma alta sensível". 329

Sem passar uma semana o Dr. Fort retomava os espaços da imprensa para escrever novo texto sobre a questão do café e agora entrando na questão francesa e patriótica pedia para Couty provar as acusações injuriosas que havia feito contra ele. Segundo Fort, se ele estivesse na França levaria a questão para outro terreno, mas não diz qual. Lamenta o ocorrido entre franceses e atribui a Couty o início da provocação. ${ }^{330}$

Louis Couty, no seu texto, questionava a situação que Joseph Fort tinha em Paris. A respeito disso dizia Fort que:

Ele sabe, entretanto, que eu tinha em Paris uma bela situação, que me permitiu de ali realizar uma modesta fortuna. Sabe que eu personificava na faculdade de medicina de Paris o ensino livre de anatomia e operações, e que este ensino caiu depois da minha partida voluntária. Sabe que a minha vida tem sido uma vida de trabalho incessante. Sabe que eu gozo no mundo inteiro de uma boa reputação de anatomista e de cirurgião. Conhece as obras de cirurgia e de medicina publicadas por mim em Paris, tendo todas diversas edições e nas quais provavelmente ele próprio aprendeu o que sabe. Enfim, ele ignora que se eu para aqui vim, posto que casado e pai de familia,

329 Gazeta de Noticias, 30 dez. 1882.

330 Gazeta de Notícias, 6 jan. 1883. 
é porque me foram buscar e eu cedi às solicitações e às belas promessas. ${ }^{331}$

É interessante notar que o Dr. Fort tinha boas inimizades na Paris do século XIX. Nasceu ele em 1835 em Mirande. Em 1855 estava em Paris para terminar seus estudos clássicos e entrar na Faculdade de medicina. Em 1863 torna-se doutor em medicina e começa ensinar anatomia na Escola prática da faculdade de medicina de Paris. A partir de 1869 tem uma série de atritos com membros do corpo docente da faculdade de medicina. Jules Ferry o encarrega de uma missão na América do Sul em 1880. Após seis meses estudando a organização das faculdades de medicina do Rio de Janeiro, Montevidéu e Buenos Aires, retorna a Paris. Contudo, encontra poucos alunos dispostos a ter aula com ele. Diante disso, pede demissão e retorna ao Brasil e posteriormente a Buenos Aires e Montevidéu. Teve vasta publicação na área de anatomia e guia de estudantes de medicina. Faleceu em 1920 na França. ${ }^{332}$

Polemistas, os franceses no Brasil Imperial. Segundo o próprio Fort, os insultos de Couty a ele teriam iniciado após trocas de cartas entre ambos. Além disso, retomava episódios anteriores na comunidade francesa do Rio de Janeiro para colocar uma questão: "quem é o Sr. Couty?". Para responder que era Couty um desconhecido entre os homens de ciência. Joseph Fort não poupou

331 Idem.

332 SANTOS, Claudia. Narrativas de viagem e a escrita da história: os franceses no processo abolicionista brasileiro (1850-1899). Rio de Janeiro: 7 Letras, 2013, p. 351-352. 
termos para os atritos com Couty. Uma questão científica despertou outras questões no seio da comunidade francesa da Corte.

Uma crítica interessante que fez Fort contra Couty se liga ao fato de ter sido o jovem cientista francês um múltiplo em suas ações, de "querer meter o nariz em tudo: na anatomia e no café; na patologia e no mate, na psiquiatria e na colonização, nas moléstias nervosas e nas internas" dizia Fort. E continuava: "Publiquei sobre o café, que o meu contraditor considerava sem dúvida como sua propriedade exclusiva, um trabalho serio, baseado sobre experiências pessoais e favoráveis ao uso do café". 333

Notamos com isso a presença marcante que a ciência teve na agricultura nas décadas de 1870 e 1880, em especial. Não havia homogeneidade na ciência como podemos notar, havia uma série de questões e soluções sobrepostas que formavam o contexto científico do final do século XIX brasileiro. O estudo da ação e das ideias de um cientista como Louis Couty exige um deslinde em que se note as ações num tempo que refaz o que desfez. Era preciso por o texto à prova dos pares amigos e inimigos e a imprensa cumpria papel de vetor do que se fazia, para numa crítica contundente ser necessário refazer o que se desfez. A modernidade se caracterizava nesses embates de criação e destruição. Tudo o que se criava em breve seria destruído, "a fim de consolidar o caminho para mais criação". 334

\footnotetext{
333 Gazeta de Notícias, 6 jan. 1883.

334 BERMAN, Marshall. Tudo o que é sólido desmancha no ar, op. cit., 2013, p. 62.
} 


\subsection{A segunda expedição de Louis Couty pelo complexo cafeeiro do Rio de Janeiro e São Paulo}

Em 1883 Louis Couty já havia percorrido as províncias do Rio de Janeiro, de São Paulo, da região Sul, estendendo-se até às regiões do Prata, em prol da qualificação dos produtos do Império. Como resultado disso publicou o relatório sobre a biologia industrial do café que foi endereçado ao diretor da Escola Politécnica do Rio de Janeiro. Nesse relatório, mais completo e complexo, estudou o complexo cafeeiro das províncias do Rio de Janeiro e São Paulo abordando-o a partir de vários pontos de vista, ampliando o que tinha feito em 1879 e respondendo as indagações encontradas no primeiro relatório e entrando com mais profundidade no problema da mão de obra.

A preocupação nesse momento era com a crise do café. Queria-se saber sobre o destino do principal item de exportação, queria-se saber sobre os rumos da cultura do café e entender com isso a crise que acometia o "preciso fruto" ${ }^{335}$ Louis Couty, por sua vez, queria saber se a crise que acometia o principal produto de exportação do Império tinha origem na própria fazenda, no modo de organização da produção. ${ }^{336}$ Nesse relatório de 1883 , Louis Couty empreendeu uma série de estudos indo do solo ao homem, da composição química e geológica da terra, do cultivo do café, de suas doenças, dos processos pelos quais se plantava e preparava o café, do uso de máquinas, do trabalho do negro escravizado, do trabalho

335 Era o termo comum na época quando se tratava do café.

336 COUTY, Louis. Étude de biologie industrielle sur le café, op. cit., 1883, p. s/p. 
do europeu imigrante, até as relações entre senhores e escravos, os hábitos de ambos chegando a elaborar uma tipologia do fazendeiro do passado e do fazendeiro do futuro. Dava ao problema da mão de obra outro olhar, o olhar do homem de ciência.

Para realizar seus estudos viajou por dezessete fazendas que compreendiam as zonas produtoras do café, do Rio de Janeiro a São Paulo. ${ }^{337}$ Nesse percurso conheceu os mais variados tipos de fazendeiros, de escravos, de colonos, de solo e de pés de café. Dividiu essa imensa área cafeeira que percorreu em duas. Uma delas limitada pelas cidades de Jundiaí, Rio Claro, Mogi tinha como centro Campinas. A outra área era compreendida por Cantagalo na província do Rio de Janeiro. No caso da província de São Paulo havia quatro qualidades de terras aptas a receber o café: massapé, a terra roxa, a salmourão e a barrenta. Na concepção de Couty e dos fazendeiros que ele consultou, a melhor terre de café do ponto de vista da cultura é "seguramente a salmourão". A menos importante das terras de café de São Paulo, na classificação de Couty, era a barrenta. Enquanto que em São Paulo os fatores favoráveis ao cultivo do café são determinados pela melhor qualidade do solo, no Rio de Janeiro o fator que melhor auxilia o cultivo do café é o clima. ${ }^{338}$

Além de vislumbrar um futuro com a imigração europeia atuando na produção do café, comparava o precioso fruto com a produção da uva na França. Dizia Couty que "nas condições atuais o café" já era igual à vinha e

${ }^{337}$ COUTY, Louis. Étude de biologie industrielle sur le café, op. cit., 1883, p. 1.

338 Idem, p. 1-3 
se tornará "facilmente superior". ${ }^{339}$ Pintou dois quadros do momento do café no final do Império. O da crise motivada pela escravidão, que seria o que ele chamou de prolongamento do passado. O outro quadro era o futuro em potencial, pois no Brasil o solo era fértil e o principal produto promissor, apenas faltava um trabalhador capaz de inovar, aperfeiçoar, e aumentar a produção.

A principal característica que Louis Couty colocou nesse relatório foi a sua definição da disciplina Biologia Industrial. Ao definir as características dessa disciplina, estava ele operando os problemas de um país novo pelas correntes de pensamento em voga no Velho Mundo. As condições fecundas da terra e o bom clima do Brasil não condiziam com o homem que trabalhava essa terra, por isso, para Couty, era preciso resolver o problema do homem. ${ }^{340}$ Segundo Lilia Schwarcz, a escola determinista geográfica, que tinha como expoente Ratzel e Buckle, advogava a tese de que o desenvolvimento cultural de uma nação seria totalmente condicionado pelo meio. Para os autores dessa escola era suficiente "a análise das condições físicas de cada país - 'dá-me o clima e o solo que lhe direi que nação se fala' - para uma avaliação objetiva de seu 'potencial de civilização'”. Com isso, Couty, como veremos, entrou nas questões da mão de obra para resolver essa equação, pois no Brasil, como ele disse, o clima era dos melhores e o solo também, só faltava um povo ativo.

\footnotetext{
339 Idem, p. 61.

340 SCHWARZ, Lilia Moritz. O espetáculo das raças: cientistas, instituições e a questão racial no Brasil (1870-1930). São Paulo: Companhia das Letras, 2008, p. 58.
} 


\section{$\{4\}$}

\section{"Sem atividade e necessidades, que ainda não são cidadãos úteis": do problema da mão de obra à constituição do povo}

As discussões sobre a mão de obra no Brasil Império tiveram vários temas que permearam o longo debate que abarcou boa parte do século XIX. No amplo debate sobre o fim da escravidão e os modos de como deveriam ser a substituição da mão de obra escrava por uma mão de obra livre algumas temas foram recorrentes: colonização, imigração, vias de comunicação, agricultura, posse da terra, o papel da pequena e da grande propriedade, o uso de máquinas no cultivo e beneficiamento do café e outras plantas econômicas, qual imigrante seria mais adequado para substituir o trabalho do negro escravizado e os meios científicos de melhorar a produção agrícola. Isto se desdobrava e aparecia um debate sobre quais elementos deveriam constituir o povo brasileiro. A discussão incluía fazendeiros, homens de governo e especialistas, cientistas, que fomentariam alternativas para o recrudescimento da produção, os meios para viabilizar esse aumento e, também discutiam qual mão de obra era mais adequada para o amanho do solo brasileiro. A discussão se desenvolvia em múltiplos fóruns: sociedades 
científicas, associações de classe, tribunas da câmara e do senado e se espraiava pela grande imprensa e pela imprensa especializada. ${ }^{341}$

O debate sobre a mão de obra se adensou entre 1870 até 1888 , período mediado pela Lei do Ventre Livre (1871), pelos Congressos Agrícolas (1878) onde se apontavam diferentes caminhos para o grande tema nacional, até a Abolição (1888). ${ }^{342}$ Nesse momento o nome de Louis Couty foi um dos mais importantes, seus argumentos entraram de forma ativa nas discussões, sedimentando imagens do país e de seu povo, ou da falta deste. Homem de ciência, suas teses sobre o Brasil eram incorporadas no discurso daqueles que faziam da imigração o processo civilizador do país.

\footnotetext{
341 Existe uma ampla bibliografia que discutiu os múltiplos debates e suas dimensões nas décadas finais da Monarquia. Ver entre outros: COSTA, Wilma Peres. "A questão fiscal na transformação republicana continuidade e descontinuidade”, op. cit., 1998, p. 141-173. GEBARA, Ademir. O mercado de trabalho livre no Brasil (1871-1888). São Paulo: Brasiliense, 1986. CARVAlHO, José Murilo de. A Construção da Ordem. Teatro de Sombras. $6^{\circ}$ edição. Rio de Janeiro: Civilização Brasileira, 2011. CONRAD, R. Os últimos anos da escravatura no Brasil (1850-1888). Rio de Janeiro: Civilização Brasileira. INL, 1977. HOLLOWAY, Thomas H. Imigrantes para o café: café e sociedade em São Paulo, 1886-1934. Tradução de Eglê Malheiros. Rio de Janeiro: Paz e Terra, 1984. EISENBERG, Peter L. Homens Esquecidos: escravos e trabalhadores livres no Brasil, séculos XVIII e XIX. $1^{\text {a }}$ edição. Campinas: editora da Unicamp, 1989. A década de 1870 também "é entendida como um marco para a história das ideias no Brasil, uma vez que representa o momento de entrada de todo um novo ideário positivo-evolucionista em que os modelos raciais de análise cumprem um papel fundamental”. SCHWARCZ, Lilia Moritz. O Espetáculo das Raças, op. cit., 2008, p. 14.

342 Cf. Anais do Congresso Agrícola do Rio de Janeiro, 1878. Introdução e notas de José Murilo de Carvalho. Fundação Casa de Rui Barbosa. Edição fac-similar. 1988. GEBARA, Ademir. O mercado de trabalho livre no Brasil (1871-1888), op. cit., 1986.
} 
O problema da mão de obra era preocupação constante no Império como indica o fato de ter sido o que mais vezes apareceu nas Falas do Trono: em 56 Falas 34 o mencionaram. ${ }^{343}$ Nesse sentido, o que se pretende neste capítulo é operar o problema da mão de obra em sua relação com a questão da constituição do povo pelas ideias de Louis Couty. Como a crise da mão de obra era narrada? Como elaborou seus argumentos para intervir nessa crise? Quais conceitos mobilizou para justificar suas teses? Quais eram seus interlocutores diretos e indiretos? Como se deu o debate? Como suas ideias foram absorvidas por um setor da sociedade que propunha reformas através da imigração? Sobretudo, como esse setor tornou-se referência usando Couty? Como nas reformas propostas podemos apreender um debate sobre a constituição do povo mediado por Couty? Sobretudo, como Couty subsidiou argumentos na questão da constituição do povo?

O olhar de Couty em relação ao Brasil é o de um jovem cientista francês que se surpreende com o que encontra e transforma tudo em problema científico a fim de ser solucionado, posto que "não há atualmente país algum onde se encontre reunido tão crescido número de importantes problemas científicos" ${ }^{\text {344 }}$ dizia ele. É a partir dessas novidades e problemas que elabora um projeto para o país, um projeto que teria por base a ciência, seu ofício, com efeito, "se o Brasil é já tão rico para o agricultor, para o comerciante, o é ainda mais para o homem de

343 CARVAlHO, José Murilo de. A Construção da Ordem. Teatro de Sombras, op. cit., 2011, p. 347.

344 COUTY, Louis. “Os estudos experimentais no Brasil”, op. cit., 1879, p. 219 . 
ciência e para o investigador". ${ }^{345}$ Nesse novo, rico e pouco explorado país uma miríade de possibilidades se abriria às mais diversas profissões.

Em 1879, ao descrever as potencialidades do Brasil, dizia quais profissões teriam grande utilidade nesse novo país e entre as profissões citadas estava a do geólogo (solo), do biólogo (homem) e a do economista (produção). Já estava no clima de estudar o Brasil a partir da junção de tais disciplinas. No caso do economista, dizia ele, "cuja ciência tende felizmente a se desprender o mais possível das fórmulas vãs para ater-se à observação precisa de condições as muito diversas, onde encontrará reunidos tantos assuntos interessantes?". No Brasil, respondia ele, onde o economista "pode estudar o termo da escravidão" e elaborar soluções para seu fim, posto que "pode ser estudado em condições tais que se chegue a averiguar se semelhante forma de trabalho com seus defeitos, elevado preço, somenos valia, já não estaria por si mesma condenada”. E continuava Couty observando que o "economista teria ainda de estudar a crise monetária, as oscilações do cambio, e, porque não o direi, se os maiores patriotas o confessem, teria de discutir o futuro financeiro de um país rico por si mesmo", rico por seu "solo e clima", rico porque suas "lavouras já florescentes se multiplicam rapidamente". O economista, pela ótica de Couty, poderia notar que nesse "país" em que suas lavouras se valem de uma "mão de obra primitiva e caríssima, produzem rendimentos muito superiores aos da Europa". Por fim, "surgiria a questão capital da

345 Idem, p. 219. 
transformação da mão de obra”, que "com tanta razão preocupa os espíritos previdentes”. ${ }^{346}$

Um país como o Brasil não poderia deixar de despertar o interesse sobre a composição de seu povo e de sua mestiçagem. Desse modo, pensava Couty que homens como Paul Broca, Quatrefages, Bertillon, Martillet, quanto interesse não teriam de estudar, para o progresso da antropologia, "não só os caracteres étnicos, criminológicos e outros das diferentes raças do Brasil, mas principalmente o cruzamento dessas raças, sua influencia sobre o desenvolvimento orgânico ou intelectual, sobre a fecundidade do mestiço etc.?!”. E como num conselho, "conforme me dizia há poucos meses o Sr. Broca, que país se encontrará, a não ser o Brasil, onde esse estudo possa ser feito facilmente e em boas condições?". 347 Desse modo, estava Louis Couty amparado, aconselhado, balizado pelas maiores autoridades do mundo da ciência.

Procurou seguir o caminho de cada profissão que ele descreveu que poderia transformar o país. Foi múltiplo, ávido, célere, em seus feitos. Acompanhou o ritmo acelerado do desenvolvimento científico e ao mesmo tempo era o próprio desenvolvimento científico. $\mathrm{Na}$ primeira missão científica que chefiou, apreendeu as dimensões do Império e de seus problemas, mas nenhum problema encontrado - insistia Couty - seria capaz de sintetizar a situação do país: "Insisto eu sobre essas questões: se o faço é porque se ligam intimamente à solução do momentoso problema que ora interessa tão perto o Brasil: o problema da mão de obra" ${ }^{348}$

346 COUTY, Louis. "Os estudos experimentais no Brasil”, op. cit., 1879, p. 222. [grifo nosso].

347 Idem, p. 221-222.

348 COUTY, Louis. "A Cultura do Cafeeiro na Província de São Paulo", op. cit., 1879 , p. 163. 
Numa palavra: se o problema da mão de obra era a questão central do Império, sua solução se inseria numa rede complexa de reformas. Ele procurava vê-las a partir dessa ciência nova, a Biologia Industrial, que ele ensinava na Escola Politécnica do Rio de Janeiro.

As análises de Couty sobre a sociedade brasileira de fins do século XIX estavam inseridas num amplo projeto de modernização do país por várias frentes. De um lado o Estado Imperial investindo no desenvolvimento da ciência para modernizar a produção agrícola através da ação cientistas como Couty, Nicolau Moreira, Emílio Goeldi, Ladislau Netto e outros. ${ }^{349}$ De outro lado, setores da sociedade imperial se organizando em defesa da imigração e da abolição. Se Couty se alinhava entre aqueles que viam a saída para o problema da mão de obra na imigração europeia, ele também pensava que a corrente imigratória ao aportar no país proporcionaria uma série de iniciativas que culminariam nas reformas necessárias ao país. Contudo, não bastava pensar numa solução externa sem se mobilizar internamente para atrair essa corrente.

A partir da definição que Couty fez da nova disciplina que ministrou na Escola Politécnica do Rio de Janeiro, a Biologia Industrial, apreendemos os modos pelos quais ele operou uma análise econômica e sociológica do Império do Brasil, matizada pelo racialismo imperante. Foi pelas possibilidades programáticas que Couty incutiu à Biologia Industrial que visualizamos a chave interpretativa pela qual entendeu o Brasil: do solo ao homem. A partir

349 Cf. LOPES, Maria Margaret, op. cit.; GUALTIERI, Regina, op. cit.; CARULA, Karoline, op. cit.; GOMES, Ana, op. cit. 
disso entendemos que o relatório/livro Étude de biologie industrielle sur le café: rapport adressé à $M$. le directeur de l'Ecole Polytechnnique publicado em 1883, reúne o máximo de possibilidades de compreensão das ideias de Couty. É o momento de maturidade de suas observações.

No momento de publicação desse relatório ele estava trabalhando em um projeto grande sobre a composição do cérebro do homem em suas dimensões psíquicas, físicas e sociais. Quanto a isso, segundo Alfredo d'E. Taunay, Couty trabalhava numa obra que trataria do sistema nervoso numa chave analítica que abordaria o aspecto físico e moral e social do homem. No primeiro capítulo dessa obra, trataria dos movimentos cerebrais e nos três capítulos seguintes mostraria como esses movimentos se produzem, bem como suas perturbações por meio do bulbo e da medula. Indicaria a natureza das sensações conscientes e inconscientes para em seguida analisar as funções psíquicas: percepções e ideias, formas conscientes, natureza emocional e social da ideia e "a este respeito, a linguagem - formação da ideia". Além disso, a hereditariedade, o instinto; a educação pessoal ou adquirida. "Os fatores físico-químicos (coma); os fatores biológicos (sono); os fatores sociológicos (loucura). Desenvolvimento cerebral. Resultantes: a personalidade, sua constituição e papel. Variações da personalidade; alcoolismo, histeria, paixões. O modo de proceder; escolha dos motivos ideativos ou sensitivos; liberdade". E, por fim, "associação das personalidades: sociologia". ${ }^{350}$ Além

350 COUTY, Louis. Pequena propriedade e imigração europeia. Obra póstuma anotada e precedida de uma introdução biográfica por Alfredo d'E. Taunay. Rio de Janeiro: Imprensa Nacional, 1887, p. 26-27. Infelizmente, não encontramos esse trabalho de Louis Couty. 
disso, havia percorrido as províncias do Rio de Janeiro, São Paulo e da região Sul, em busca de solucionar a crise da mão de obra e suas crises decorrentes.

A Biologia Industrial visava apreender as complexidades da organização social em todos os níveis, do econômico ao sociológico, passando pelo biológico e dar soluções para os problemas encontrados. Nesse sentido, a mercadoria do ponto de vista da biologia industrial seria considerada como produto biológico do solo e do clima, mas também do homem, resultando do seu trabalho. ${ }^{351}$ Para tanto, compara a Economia Política e a Sociologia com a Biologia Industrial e observava que esta,

penetra mais no problema e especializando-se, estuda o esforço produtivo do homem, considerando-o em relação às suas diferentes necessidades; e em seus esforços, concentra-se especialmente àqueles que tem por objeto a utilização dos seres do reino vegetal ou animal: assim, esta ciência cria uma ligação estreita entre as ciências sociológicas e as ciências biológicas, mantendo um lugar fácil de delimitar. ${ }^{352}$

Aliando a esse instrumental teórico que ele desenvolveu, possuía uma compreensão do mercado e da interligação entre as economias e os efeitos da crise na mercadoria. A mercadoria, segundo Couty, "depende da natureza da mão de obra, de sua perfeição, de seu custo alto ou baixo". Prosseguia, observando que a mercadoria "depende da quantidade de trabalho acumulado, e de

351 COUTY, Louis. Étude de biologie industrielle sur le café, op. cit., 1883, p. 64 .

352 Idem. 
suas formas; depende ainda de fatores sociais mais complexos”. Desse modo, apurava seu argumento notando que "a falta de trabalhadores ativos na Turquia e na Espanha, a crise dos salários na França e na Inglaterra, a insuficiência de capitais, de estradas, de máquinas na Itália e na Grécia, a servidão na Rússia, o aluguel na Irlanda”, somados à "escravidão no Brasil, nos mostram as causas múltiplas que podem alterar a produção e variação do seu preço de custo". ${ }^{353}$

Preocupado em responder os motivos da crise do café, mostrava como o mercado mundial se constituía e como que as relações do mercado e as especificidades de cada país poderiam alterar os preços. Com isso, visava mostrar que a culpa não era apenas do Brasil, mas das consequências de um sistema. Procurava mostrar o caminho para o Brasil se consolidar de forma hegemônica nesse mercado mundial do café e dos demais produtos que por ventura o país viesse produzir.

É importante observar que a estrutura desse livro é consequência de vários estudos, vários relatórios que Couty realizou após vistoriar algumas fazendas das províncias do Rio de Janeiro e São Paulo. Nesse sentido, o relatório/livro sobre a Biologia Industrial do café não foi resultado de uma missão específica, mas da somatória delas. Prova disso é a questão que apareceu no relatório sobre a propaganda do mate, café e carne seca na Europa, que dizia ser alto demais o custo da produção do café. ${ }^{354}$ Daí decorreu a necessidade de elaborar um

353 Idem.

354 COUTY, Louis; TAUNAY, Luiz Goffredo de Escragnolle; TELLES, Augusto Carlos da Silva. Propaganda na Europa do mate, do café e da carne seca, op. cit., p. 24. 
programa de estudos baseado na análise do custo da produção do café. Essa questão está ligada ao problema que Louis Couty formulou para responder qual era a origem da crise do café. Para tanto, "o programa dos trabalhos práticos da cadeira de Biologia Industrial” que a Escola Politécnica aprovou "tem por título: o preço de custo do café”. 355

$\mathrm{Na}$ primeira parte, como já apontamos, ele demonstrava as características do solo, da vegetação e as possibilidades que se pode obter desde que o solo seja muito bem manejado. Na segunda parte Couty analisou a dimensão econômica, do mercado mundial de café, e como a introdução de equipamentos desenvolvidos, praticado em certas fazendas, auxiliaria no aumento da produção do café brasileiro, na melhora da qualidade e no aumento do seu preço rendendo maiores lucros. A atenção dada à mão de obra se deu ao logo das duas partes do relatório. Couty queria mostrar, o que seria sua obsessão, como uma mão de obra cara e de má qualidade impede o maior desenvolvimento da produção e do país. Analisou as várias interfaces da questão. Operou o problema da mão de obra articulando seu olhar de homem de ciência com as possibilidades que a Biologia Industrial oferecia. Por ser uma disciplina nova, entendemos que Couty caracterizou a abordagem dos objetos dessa disciplina a partir de suas convicções, ampliando suas possibilidades. Portando, a abordagem sociológica, propriedade característica da disciplina, era necessária para problematizar o homem no manejo produtivo do

355 COUTY, Louis. Étude de biologie industrielle sur le café, op. cit., 1883, p. 1 . 
solo. Por isso, para Couty, no Brasil, o solo precisava do homem. Dado um solo fértil era preciso transformá-lo a partir de mãos habilidosas, mãos que só deveriam ter uma origem: a europeia. É do ponto de vista da disciplina nova que Couty aborda a sociedade brasileira, que opera os problemas do país pelas ideias novas em voga.

\subsection{O papel da Lei do Ventre Livre (1871) na formação do pensamento de Couty sobre o Brasil}

[...] a lei de 1871 que garante a completa supressão da escravatura em menos de trinta anos, é obra tanto do Imperador quanto de um estadista oriundo do povo, cuja morte recente foi vivamente lamentada: Paranhos, visconde do Rio Branco. ${ }^{356}$

A Lei de 28 de Setembro de 1871, Lei do Ventre Livre, Lei Rio Branco, assumia no pensamento de Louis Couty um aspecto crucial, na medida em que ele via nessa lei o modo mais perspicaz de conduzir a transformação da mão de obra escrava para uma mão de obra livre. A Couty agradava o caráter transitório que a Lei do Ventre Livre impunha no governo da transição. O Brasil observado por Couty era o da transição, e nada mais significativo do que uma lei que conduzisse o processo sem revolução. Apreende a necessidade dos cafeicultores aferrados à escravidão, ao status quo da grande propriedade escravista e nutri essa dimensão reflexiva de um setor social com seu precioso saber científico.

356 COUTY, Louis. A escravidão no Brasil, op. cit., 1988, p. 54. 
A situação atual, dizia ele em seu primeiro olhar (1879), “deve ser apenas considerada como um período eminentemente transitório, tanto mais útil quanto mais curto for". ${ }^{357}$ Suas primeiras observações gerais sobre o que encontrou indicava que o Império do Brasil estava em um momento de transição e a Lei de 28 de Setembro de 1871 cumpriria função estratégica na operação de transformar a mão de obra.

O posicionamento contrário de Couty em relação às transformações abruptas, a abolição imediata, e nesse posicionamento estava seu apreço pela Lei do Ventre Livre, se baseava na sua constatação de que faltava "homens livres ativos, aptos para os trabalhos agrícolas e capazes de uma atividade regular" no Império. Isto é, se fosse abolida a escravidão o Império não teria condições de manter a produção agrícola no nível que se encontrava. Nesses termos, "suprimir bruscamente a escravidão significaria suprimir ou reduzir todas as produções importantes, e fazer secar as fontes da renda nacional ou individual”. As consequências seriam desastrosas na medida em que o Império se encontraria "na impossibilidade de honrar seus compromissos" com os países da Europa. ${ }^{358}$

A Lei do Ventre Livre (1871) se insere num conjunto de leis que visou abolir a escravidão sem acrescer danos à produção agrícola do país, melhor dizendo, sem danos aos grandes proprietários. Além de abolir de forma gradual a escravidão, procurou permitir aos grandes proprie-

357 COUTY, Louis. "Os estudos experimentais no Brasil”. Revista Brazileira; ano 1, tomo 2, p. 232, out./dez. 1879.

358 COUTY, Louis. A escravidão no Brasil. Tradução de Maria Helena Rouanet. Rio de Janeiro: Fundação Casa de Rui Barbosa, 1988, p. 51. 
tários se desvencilhar de seus escravos, de acordo com suas possibilidades, e sem que perdessem o controle sobre a força de trabalho. Seu objetivo era fazer com que os senhores mantivessem os ingênuos até os 21 anos e que depois dessa idade estes contratassem seus serviços aos ex-senhores. ${ }^{359}$ Em seu bojo esta lei trazia o componente decisivo para a organização e disciplina do mercado de trabalho livre no Brasil. Com efeito, a obra de 1871 formulou a estratégia de definição da abolição da escravidão e transição para o trabalho livre, bem como para a configuração do mercado de trabalho livre. ${ }^{360}$

Para embasar seu argumento da necessidade gradual, Couty apontava uma série de hábitos abolicionistas que justificavam, ao seu olhar, o modo regulador de conduzir a abolição total. Eram alforrias que aconteciam acompanhadas de atos festivos onde o senhor concedia a liberdade ao escravo. Aproveitava-se a ocasião de um aniversário, de um casamento para colocar em prática tal hábito. Isto seria por parte do senhor de escravos uma iniciativa que preenchia a "falta de iniciativa individual" dos negros. ${ }^{361}$ Dizia ele que "todas as solenidades, todas as alegrias familiares, todos os grandes acontecimentos domésticos ou nacionais servem de pretexto ou de motivo para tais libertações". ${ }^{362}$ Além disso, outro hábito notado por Couty se dava no leito de morte do senhor que libertava seus escravos mais próximos.

\footnotetext{
359 BARBOSA, Alexandre de Freitas. A formação do mercado de trabatho no Brasil. São Paulo: Alameda, 2008, p. 127.

360 GEBARA, Ademir. O mercado de trabalho livre no Brasil (1871-1888), op. cit., 1986 , p. 11.

361 COUTY, Louis. A escravidão no Brasil, op. cit., 1988, p. 62.

362 Ibidem.
} 
Esses hábitos, Couty os entendia como corriqueiros e era assim que analisava a situação do negro diante do "grande número de libertações". Segundo seus dados, cerca de quarenta mil escravos haviam sido alforriados nos últimos quatro anos, isto é, de 1877 até 1881, a partir de um hábito que em conjunto com as leis possibilitava uma ampla cota de alforrias. Esses hábitos em conjunto com a legislação seriam, para Couty, mecanismos de emancipação baseados no costume nacional.

Pode-se compreender, agora, o mecanismo da emancipação do Brasil. Esta sempre existiu, lenta e progressiva, porque faz parte dos costumes e dos hábitos nacionais. Começou com a mistura de cores, antes das grandes levas de escravos que chegaram no início do século [XIX] e continuou com as alforrias conquistadas individualmente por certas raças e, principalmente, com as numerosas libertações outorgadas pelos senhores de escravos. $^{363}$

Seria a partir dessa observação que Couty entendeu que no Brasil as transformações bruscas não dariam certo, contribuindo assim para a ideologia da permanência no imaginário nacional. Posto que, com hábitos libertários os senhores e a sociedade de modo geral garantiam ao negro livre e fácil entrada como cidadão na sociedade. A única barreira que impedia a ascensão do negro na sociedade seria sua "falta de iniciativa individual". E por não ter esse hábito era preciso substituir seu trabalho por trabalho mais qualificado.

363 Idem, p. 63. 
[...] Os ministros de 1871 tiveram confiança no futuro do País, na sua abundante riqueza, no seu solo, no seu clima, na sua flora tão favorecida. Compreenderam que o que faltava a essas riquezas naturais, sem valor por si só, era a mão de obra inteligente e ativa e o equipamento social que deviam torná-las úteis e vantajosas [...]. ${ }^{364}$

A base de sustentação do argumento de Couty sobre a força da Lei do ventre Livre, encontra-se na citação acima. Couty entendia o país como uma pedra preciosa bruta à espera de ser lapidada, polida, a fim de reluzir num futuro esplendoroso. Tinha um solo e um clima de ótima qualidade. Tendo toda essa riqueza, o que faltava? A mão de obra qualificada, ativa, capaz de produzir o melhor em prol do país. Mas qual mão de obra deveria aportar no país? A europeia, com sua organização ativa e próspera fomentaria um povo novo e hábil na condução do progresso. O Brasil possuía o solo, mas precisava do homem. E a lei de 28 de setembro de 1871 cumpria papel nessa revolução lenta e gradual sonhada por Couty.

Assim sendo, as estradas de ferro se estenderam rapidamente a partir de 1871 e várias províncias importantes já se tornaram, desta forma, acessíveis. Em São Paulo ou Minas, podemos ver estradas transformando a floresta virgem, à medida que vão avançando, em novas regiões habitadas e cultivadas. ${ }^{365}$

Louis Couty viu uma ação modernizadora dessa lei, na medida em que após ela, o país presenciaria o

364 Idem, p. 71. [grifo nosso].

365 COUTY, Louis. A escravidão no Brasil. Op. Cit. 1988, p. 72. 
aparecimento de uma rápida expansão das linhas férreas. Nessa relação que Couty empreendeu, o país estaria preparando o ambiente para um maior desenvolvimento com a imigração. Por acreditar que "não existe transformação brusca em lugar nenhum", o ato da Lei de 28 de setembro de 1871 era a maneira mais adequada de conseguir a transformação desejada do trabalho escravo para o trabalho livre.

Jamais acreditei na influência criadora de qualquer legislador. Acho que as reformas mais justas, mais úteis em si mesmas, só podem dar resultados depois de terem sido preparadas e tornadas necessárias através do meio, dos costumes, do conjunto das condições biológicas e sociológicas. Os artigos de lei não possuem virtude mágica que os torne capazes de transformar, em pouco tempo, milhões de homens de raças diversas e de constituir cidadãos ativos e econômicos em locais onde o trabalho livre está apenas se iniciando. ${ }^{366}$

Para Couty, a lei só cumpriria sua obra se a ela fosse ajustada às ações em conjunto dos fazendeiros. O principal aspecto que Couty assimila dessa lei foi o do costume, tão caro a ele. Por ser tal lei elaborada no bojo de costumes, ela teria resultados mais significativos do que uma lei que pusesse fim ao trabalho escravo e deixasse os fazendeiros na mão. É importante contrastar essa ideia de Couty com o que colocou Alexis de Tocqueville sobre a emancipação dos escravos nas colônias francesas da primeira metade dos Oitocentos. Analisando as duas

366 Idem, p. 89. 
formas, gradual e direta, de realizar a abolição, Tocqueville notava que a abolição "simultânea" - direta - de todos os escravos seria a melhor solução para as colônias da França. Enquanto que a abolição gradual oferecia inconvenientes e mais perigos por apresentar como consequência a formação de uma classe à parte para quem seria necessária a criação de uma legislação especial; haveria ao mesmo tempo homens livres e escravos, sendo os livres abusadores de sua independência ao levarem uma vida "ociosa e vagabunda". O trabalho, nessas condições, se manteria como o estigma da escravidão e "cada negro que consegue a liberdade é, naturalmente, levado a considerar o ócio como o mais doce e o mais glorioso privilégio da sua nova condição". 367

Louis Couty não vai comungar do mesmo pensamento de Tocqueville, nem do pensamento dos abolicionistas brasileiros e, sobretudo, nem do pensamento de Victor Schoelcher, pois queriam a abolição total. Desse modo, o debate que Couty teve com Schoelcher e com os abolicionistas brasileiros é decorrente dessa interpretação. Os únicos homens capazes de conduzir a transformação do trabalho seriam, para Couty, os fazendeiros e a lei de 1871 se realizaria na ação desses fazendeiros.

\subsection{0 escravo e sua enxada}

[...] o Sr. Dr. Luiz Couty que, em numerosos trabalhos que correm impressos, e em artigos notáveis

367 TOCQUEVILLE, Alexis de. A emancipação dos escravos. Tradução de Fany Goldfarb. Campinas: Papirus, 1994, p. 38-40. 
que tem aparecido no Messager du Brésil, tem demonstrado que o trabalho escravo é mau e caro, que o trabalho nacional é numericamente insuficiente, e pelas suas condições naturais incapaz de por si só dar a exploração de nossos recursos o impulso necessário. ${ }^{368}$

O trecho acima é de Ferreira de Araújo, e a menção que o jornalista fez a Louis Couty demonstra o quanto suas ideias sobre a questão da mão de obra eram aceitas como referência no assunto. Ao mesmo tempo é evidência de sua inserção nas discussões sobre as questões que mais urgiam na década final do Império do Brasil.

Nesse quadro, Louis Couty caracterizou o trabalho do negro escravizado e após essa caracterização atribuiu ao trabalho escravo a culpa pela crise que passava a lavoura de café entre as décadas de 1870 e 1880. Em sua descrição, o trabalho do escravo era mau e caro, não possibilitava boa produção e nessa produção os frutos do café, por exemplo, eram de má qualidade. Mas, apesar do trabalho do negro escravizado ser constantemente criticado, Couty abria uma única exceção para os negros-mina. Na hierarquização racial e laboral dos negros feita por Couty, os mina tinham conseguido "tirar proveito de condições tão favoráveis” que o regime escravista

\footnotetext{
368 Gazeta de Notícias, 16 jun. 1884. O artigo esta presente na seção “Cousas Políticas”. Apesar de não aparecer o nome do autor do referido artigo, entendemos que seja Ferreira de Araújo, porque em outras oportunidades Couty se referiu a esta seção como sendo assinada pelo sócio proprietário da Gazeta de Notícias. Além disso, Ferreira de Araújo publicou um livro onde reuniu seus artigos com o título Cousas Politicas: artigos publicados na Gazeta de Notícias de março a dezembro de 1883. Rio de Janeiro: Tipografia da Gazeta de Notícias, 1884.
} 
possibilitava. Essas condições favoráveis mencionada referem-se à entrega negociada de porções de terras que o senhor fazia para com os escravos, sendo os mina os únicos que souberam aproveitar tal benesse. Enquanto os "outros negros, isto é, a quase totalidade dos indivíduos da raça, não souberam fazer qualquer esforço para conquistar a própria liberdade" dizia Couty. ${ }^{369}$

Na caracterização do trabalho escravo vamos notar o argumento de Couty se relacionando com os propósitos da Lei do Ventre Livre, ou seja, ao argumento da emancipação gradual e "progressiva" como ele gostava de dizer. Para ilustrar o que pensava, recorria a elementos cotidianos da vida brasileira.

Poderia citar fatos cotidianos, que todos já presenciaram: este escravo é bom cozinheiro, esse outro é carregador, carpinteiro ou pedreiro, e todos eles trabalham bem. Eles são libertados e, pouco tempo depois, tendo-se tornado beberrões ou preguiçosos, só trabalham quando obrigados por necessidades muito limitadas $[\ldots] .{ }^{370}$

Nesses termos, estava em risco a produção agrícola, caso fosse realizada a abolição em 1881, ano que fez a observação. Na imagem de Couty, os negros libertos não continuariam na produção agrícola e por isso a abolição gradual ajustaria a libertação dos negros à chegada de imigrantes para substituí-los, já que quando libertos os negros não trabalhariam mais. Além disso, se o negro não fosse subjugado ele não trabalhava. O escravo

369 COUTY, Louis. A escravidão no Brasil, op. cit., 1988, p. 62.

370 Idem, p. 66. 
não teria motivação, iniciativa, como queria Couty e por isso pouca aptidão para o trabalho produtivo. Dizia Couty que se alugado fosse o escravo quem ganhava com seu aumento era seu dono, "se fica em casa do proprietário, tem menos ainda a esperar". Com isso, sabia que "se o senhor estiver tendo lucro com ele, lhe dará sempre comida para vê-lo gozando de boa saúde". Se já tinha o alimento não teria "esforço" nem "luta individual" e assim estava com "o amanhã” garantido "já que representa um capital e não um indivíduo" ${ }^{371}$ O negro, portanto, não seria um indivíduo social útil, o negro para Couty não seria um indivíduo, seria um capital empregado com todos os riscos de perdas e ganhos. Seus argumentos iam de encontro aos interesses dos cafeicultores, sempre contra o negro escravizado.

Desde seu início no Brasil, concebe o trabalho escravo como "raro" e "caro" e, sobretudo de má qualidade, por isso precisava ser substituído. Em 1879, no reconhecimento, atuava como mediador de ações que poderiam aumentar a produção e via no uso de máquinas e instrumentos como a carpideira uma possibilidade de substituir o trabalho escravo. Nesse cenário se questionava e questionava os leitores: "a mão de obra escrava deve ser substituída pelas máquinas agrícolas? Efetivamente será este o meio mais adequado de tornar o trabalho menos raro e, sobretudo, menos caro" no Brasil. Se isso aparecia como solução mais adequada, como "operar semelhante transformação do trabalho?". Nisso se abria as possibilidades de transformação não apenas da mão de obra, mas

371 Idem, p. 76. 
de todo o aparato produtivo da agricultura do Império. Para tanto, Couty questionava se nessa transformação caberia o uso do arado europeu "que se destina a revolver as camadas superiores do solo para lavouras anuais, será conveniente num solo arável muito espesso e principalmente para lavouras de raízes profundas, como cafeeiros, algodoeiros, canas, muitas vezes antigas?". Ou, se esse arado feito para o solo europeu poderia ser substituído por um fabricado no Brasil, portanto, "mais apropriado ao solo e às lavouras do Brasil?”. Para Couty, essas questões poderiam "ser resolvidas por um engenheiro especialista, mediante observações e experiências precisas, feitas por si mesmo ou pelos fazendeiros, cujo concurso de certo não lhe faltará". ${ }^{372}$ Essas questões e soluções colocadas por Couty sobressaem num pano de fundo que tinha o trabalho escravo como predominante, porém esse trabalho escravo estava com seus dias contados por obra da Lei do Ventre Livre. Nesse sentido, Couty visava uma transformação mais completa e intensa ao incentivar a criação de equipamentos adequados à realidade do solo brasileiro sem ter que recorrer aos produzidos na Europa ou Estados Unidos. Exemplo desse incentivo encontra-se na criação da Máquina de Secar Café Taunay-Telles produzida pelos engenheiros e professores Goffredo Taunay e Augusto Telles no laboratório de Biologia Industrial da Escola Politécnica dirigido por Couty. Somado a isso, viria os imigrantes, que na concepção de Couty seriam os mais aptos a manejar e a criar tais tecnologias.

372 COUTY, Louis. "Os estudos experimentais no Brasil". Revista Brazileira, ano 1, tomo 2, p. 223, out./dez. 1879. 
A narrativa que Couty fez sobre o que viu pelas fazendas que visitou e paisagens que observou, além dos relatos que obteve de outrem, tinha um cenário em que o trabalho escravo se manifestava e se relacionava com o que ele classificou de primitivo, atrasado, de entrave. Assim, dizia ele que os "cafezais cultivados pelos escravos são trabalhados com o auxílio de métodos primitivos". Não havia inovação no trabalho escravo, nem automação. Apesar disso, não negava que as plantações "em geral muito bem tratadas [...] causariam a admiração de nossos agricultores" europeus, sempre "mais exigentes". Todavia, toda essa produção requeria "um imenso dispêndio de mão de obra”. ${ }^{373}$ Tornando-se um entrave na medida em que as fontes de obtenção do trabalho escravo - tráfico transatlântico e nascimento ${ }^{374}$-, haviam secado, sobretudo com a Lei do Ventre Livre (1871). Além disso, Couty via a simbologia do atraso do trabalho do escravo num instrumento que segundo suas observações "revolvia à mão" a terra. Era com auxílio dessa "espécie de instrumento" de cavar que o escravo trabalhava o

373 COUTY, Louis. A escravidão no Brasil, op. cit., 1988, p. 78-79.

374 Citando Perdigão Malheiro, Barbosa observa que em 1850 com a abolição do tráfico transatlântico de escravos, o país viu esgotar a infame fonte de braços africanos a serem escravizados. Assim, com a Lei Eusébio de Queirós, de 4 de setembro de 1850, o regime escravista encontrava um limite. Segundo Perdigão Malheiros, a escravidão até 1850 estava alicerçada em duas bases: de um lado o tráfico transatlântico de africanos, e de outro lado a hereditariedade e perpetuidade pela reprodução. Com a Lei Eusébio de Queirós apenas uma base permanecia de sustentáculo para o regime. BARBOSA, Alexandre de Freitas, op. cit., 2008, p. 94. Com a Lei do Ventre Livre as duas fontes secavam. 
solo. ${ }^{375}$ Esse instrumento era a enxada, que no olhar de Couty não seria nada além da extensão da mão do escravo, por isso primitivo, pois não dava autonomia ao manter o trabalhador em contado direto com a produção.

O que faltava nessa paisagem da produção cafeeira que tinha o trabalho escravo como principal força? Se o trabalho escravo era primitivo, caro, necessitando de um elevado contingente de trabalhadores que já se encontravam em condição de escassez, por isso também raro, era preciso substituir num primeiro momento, ainda que de modo gradual, os escravos por máquinas e instrumentos agrícolas. Essas máquinas e outros instrumentos desejados por Couty no cafeeiro eram, em 1881, segundo ele "introduzidos em raros pontos do país". 376

Essas conclusões de 1881 sobre o negro e sua enxada não serão alteradas anos mais tarde, em 1883, no seu relatório/livro sobre o café. Se em 1879 Couty considerava a mão de obra escrava inferior e que eram poucas as iniciativas tecnológicas empregadas na produção cafeeira, em 1881 corroborou seus primeiros diagnósticos e, em 1883, em seu mais completo trabalho sobre a produção do café, enfatizava que "comme conclusion, partout où cela est possible, on devra remplacer le noir et son exada par le mulet et la capideira". ${ }^{377}$ Para seu argumento estava claro que nesse curto percurso de tempo, o trabalho do escravo não tinha evoluído, confirmando assim o que pensava desde o início.

375 COUTY, Louis. A escravidão no Brasil, op. cit., 1988, p. 78-79.

376 Ibidem.

377 "Como conclusão, onde for possivel, devemos substituir o negro e sua enxada pela mula e carpideira”. Tradução Livre. COUTY, Louis. Étude de biologie industrielle sur le café, op. cit., 1883, p. 27-28. 
A Gazeta de Notícias, analisando seu relatório sobre o café de 1883, concordava com suas ideias, mas colocava oposição em alguns aspectos, especialmente, "no que diz respeito ao amanho do solo, ao ensaio de culturas novas e ao emprego de estrumes”. Contudo, em relação à mão de obra: "O que é necessário fazer, quanto antes, é melhorar e tornar mais abundante a mão de obra agrícola entre nós, diz acertadamente o Dr. Couty". ${ }^{378}$ Essa abundância de mão de obra era em relação à mão de obra imigrante, posto que era esse o cenário idealizado por Couty: o de um enorme contingente de imigrantes europeus trabalhando em pequenas propriedades.

A produção do negro nas fazendas, segundo as observações de Couty, era irregular, já que o negro seria incapaz de realizar "operações mais aperfeiçoadas de cultivo". Além disso, a produção do trabalho escravo estava sujeita às intempéries do tempo e necessitava de constante vigilância, posto que "são necessários mais feitores para vigiar trezentos escravos do que contramestres para fiscalizar mil e duzentos trabalhadores livres”, o que significava uma importante diferença no preço do custo do trabalho. Com o negro o fazendeiro despenderia mais gastos para manter vigiada a produção, com o imigrante isso não ocorreria. ${ }^{379}$

Esses problemas que Couty visualizou na produção do café implicaria para ele na má qualidade do produto no mercado. Má qualidade que seria refletida no baixo preço do produto e no menor lucro. Para Couty, essa

378 A Gazeta de Noticias, 12 ago. 1883.

379 COUTY, Louis. A escravidão no Brasil, op. cit., 1988, p. 79. 
situação “desfavorável” permaneceria enquanto "a mão de obra direta do escravo não fosse substituída por diversas máquinas já bastante aperfeiçoadas". 380

Na vistoria dos espaços de produção do café entre 1881 e 1883, Couty se preocupa em saber "se a crise atual do café não tinha suas causas na própria fazenda, em seus métodos de cultivo ou organização [...]" ${ }^{381}$ Nessa missão, observou e descreveu todos os percursos da produção do café, do preparo do solo até a lavagem do café e da ação do trabalho escravo nesse processo. Atento a isso notava que o sabor do café, bom ou mal, era decorrente de todo o processo de preparo do solo até a secagem e embalagem do café a ser vendido. Na percepção de Couty, as falhas ao longo do processo culminariam na alteração do sabor, daria ao café o temido goût de terroir que atrapalhava a fama do café brasileiro. ${ }^{382}$ Por isso sua preocupação em chamar a atenção para cuidados que podiam ser desprezados no processo de cultivo e preparo do café. Todos os possiveis defeitos que o café adquiria, todas as falhas de sua dinâmica no mercado internacional, Couty atribuía ao trabalho escravo.

Para ele, a qualidade na produção dos frutos iria fornecer frutos regulares. Assim, uma espécie de mantra ditava o ritmo de suas ideias: "melhor cultivar, melhor colher, melhor secar", só assim se teria um fruto melhor, mais regular, padronizado. Em decorrência da melhora

380 Idem.

381 COUTY, Louis. Étude de biologie industrielle sur le café, op. cit., 1883. s/p.

382 Numa tradução livre: “gosto de terra”. COUTY, Louis. Étude de biologie industrielle sur le café, op. cit., 1883, p. 33-34. 
da produção o fazendeiro sentiria o aumento nas vendas. ${ }^{383} \mathrm{Com}$ isso, Couty procurava em todas as possibilidades enfatizar que os erros da produção eram decorrência da qualidade ruim da mão de obra escrava e que havia uma solução, desde que o país se movimentasse, se organizasse, para receber imigrantes. Imigrantes que trariam inovações e empreenderiam o uso de máquinas e equipamentos capazes de aumentar a qualidade e a produção do café.

Em um artigo na Gazeta de Notícias de título "Inferioridade econômica do escravo", um autor, que não teve seu nome indicado, ao analisar a questão da mão de obra escrava observava que:

O trabalho escravo é o mais barato de todos, pois não é pago - dizem ainda hoje não poucos fazendeiros, e contrariá-los torna-se difícil, em vista da carência de estudos precisos, feitos no Brasil, sobre a mão de obra servil e o rendimento. ${ }^{384}$

Sentida a carência de estudos, num cenário de carência e carestia de braços, até para contrapor o argumento dos fazendeiros, os trabalhos de Louis Couty ocuparam esses espaços vazios e ao preenchê-los era alçado como referência no tocante aos estudos da mão de obra. Para tanto, o artigo da Gazeta de Notícias prosseguia indicando que:

A brochura do Dr. Couty, relativa ao café, de que já demos conta nesta folha, permite rebater tal

383 COUTY, Louis. Étude de biologie industrielle sur le café, op. cit., 1883 , p. 56-60.

384 Gazeta de Notícias, 21 ago. 1883. 
asserção [de carência de estudos], e evidencia que o trabalho escravo é o mais caro de todos, porque, se despende pouco, rende menos ainda. ${ }^{385}$

O autor do artigo concluía, com Couty, quando descrevia os problemas da mão de obra escrava com trechos de Couty para apontar que o custo elevado das fazendas de café era elevado porque tinha o escravo como principal força, "eis o que provou o Dr. Couty". 386

Os relatórios e livros de Couty nesse contexto de ausência de estudos indicada pelo artigo da folha apontava que a mão de obra escrava era mais cara ao exigir custos de manutenção e por render pouco ao fazendeiro, especialmente quando posta em comparação com os resultados de máquinas e do trabalho do imigrante europeu. Desse modo, diante da ausência de estudos, os relatórios de Couty formavam as concepções sobre a inferioridade do trabalho do negro escravizado como podemos notar.

O movimento das ideias de Couty nesse contexto de transição do trabalho escravo para o livre encontrava nos meios de comunicação, nos jornais e revistas um meio de ampliar e consolidar o discurso da urgência, do ponto de vista de Couty, não de abolir a escravidão, mas antes atrair imigrantes a fim de que ao ser realizada a emancipação dos escravos os fazendeiros não se preocupariam com as consequências da abolição, manteriam a produção em sua continuidade. Sobretudo, era preciso atrair imigrantes e substituir o trabalho escravo "não porque seja prejudicial a uma classe de homens [aos

385 Idem. [grifo no original].

386 Idem. 
fazendeiros], mas porque é prejudicial a toda uma evolução social" ${ }^{387}$ Isto é, para o cientista francês, o negro não seria um problema econômico, seria um problema na evolução social do país. Com esses argumentos, Couty sedimentava a ideia de que o negro não seria útil como elemento constituinte do povo brasileiro.

\subsection{0 domínio da máquina sobre a enxada}

Louis Couty não via evolução no trabalho manual, por isso, ao comparar o trabalho do escravo com o de máquinas ou instrumentos sempre enfatizava a qualidade e a homogeneidade que o processo mecânico possibilitava. Além disso, a perda na produção seria menor quando comparada com a perda no processo realizado pelo trabalho escravo. Com o uso de máquinas e instrumentos agrícolas o fazendeiro evitaria o emprego direto da mão de obra escrava na produção, podendo realocar essa mão de obra em outras atividades. ${ }^{388}$ Couty procurava mostrar que com as inovações a produção ganharia qualidade e produtividade. Sobretudo, o fazendeiro diminuiria os custos com a mão de obra escrava. ${ }^{389}$ Com a produção manual, o café estava sujeito às intempéries do dia ou da noite. Está sujeição ao tempo, além de atrapalhar na produção, proporcionava aos escravos uma condição de vulnerabilidade, na medida em que diante de uma chuva noturna eram "arrancados violentamente"

387 COUTY, Louis. A escravidão no Brasil, op. cit., 1988, p. 74.

388 COUTY, Louis. “Maquina de secar café”, op. cit., 1880, p. 205.

389 Idem, p. 205-206. 
do sono diretamente para o terreiro e proteger o café da umidade, vindos assim quentes da cama, sem precaução alguma, "expor-se às intempéries e esvaziar o terreiro, para talvez tornar a enchê-lo no dia seguinte, passada a tormenta. Quantas moléstias não são devidas a isto?”. Sendo o escravo um capital do fazendeiro, ao se sujeitar a essas doenças, estaria o fazendeiro perdendo, não lucro, mas também um instrumento capitalizado. Couty não estava preocupado com a saúde do negro, mas sim com a perda da mão de obra, isto é: "Sabem os fazendeiros que muitos escravos são vítimas de pneumonias e outras afecções apanhadas nessas ocasiões, dai provindo perda considerável e definitiva de mão de obra". ${ }^{390}$ Os cálculos de Couty tinham o objetivo de mostrar ao fazendeiro o que seria melhor para a sua produção.

Para demonstrar a superioridade da máquina sobre o braço escravo, elaborou alguns cálculos a fim de conquistar o interesse do fazendeiro. Assim, ao utilizar uma máquina o fazendeiro estaria livre de vários custos que oneravam a operação produtiva da fazenda, mas além de reduzir os custos com a mão de obra, o fazendeiro, ao utilizar uma máquina estaria livre de outros custos secundários como o de alimentar e vestir seus escravos. ${ }^{391}$ Outro aspecto dessa redução dos custos enfatizados por Couty se encontrava no aparato de montagem de uma fazenda. Com máquinas de secar o café não seria mais necessário à instalação de terreiros de secagem do café. Ao ser utilizada "uma máquina [...] seja qual for o seu

390 COUTY, Louis. “Maquina de secar café (sistema Taunay-Telles)”, op. cit., 1883, p. 36. [grifo nosso]

391 Idem, p. 36-37. 
preço definitivo, será sempre muito menos dispendiosa do que a instalação de terreiros [...]" onde atuava o escravo. ${ }^{392}$

\subsection{A inferioridade do trabalho escravo em sua longa duração}

[...] sua produção [do escravo] é muito cara, de má qualidade e pouco abundante. Tudo isso é hoje em dia demonstrado por vários estudos precisos que não podemos aqui resumir e a inferioridade do negro em relação ao homem livre não é negada por mais ninguém. ${ }^{393}$

Louis Couty asseverou isso em 1884, mas frase semelhante poderia ser encontrada em seus escritos em 1879, quando chegou ao Império do Brasil e lançou seu primeiro olhar. A ideia da inferioridade do negro e do seu trabalho, como disse Couty, era objeto de vários estudos que argumentavam com a finalidade de justificar essa dita inferioridade laboral e, também, intelectual. Quanto aos estudos que procuravam demonstrar a má qualidade do trabalho do negro, Couty já era, nesse aspecto, um desses estudos como fica demonstrado na citação seguinte:

Desse conjunto de fatos ressalta uma conclusão: o custo da produção do café no Brasil é exagerado. A nosso ver, é isso devido à natureza da mão de obra, que é cara e má; e ao seu emprego direto em excesso. Louis Couty (L'esclavage au Brésil)

392 Idem, p. 37.

393 COUTY, Louis. "Exploração e colonização”. (4 a 11 nov. 1883). In: O Brasil em 1884: esboços sociológicos, op. cit., 1984, p. 80. [grifo nosso]. 
procurou mostrar que o trabalho escravo importa em duas vezes mais do que o de um trabalhador livre na Europa. Os seus cálculos foram impugnados, porém é fácil reconhecer que são exatos, quando não se conta e compara só como despesa o dinheiro desembolsado. O assalariado na Europa é alugado para certo fim, e pago apenas pelo trabalho feito, cabendo-lhe tratar do sustento seu e de sua família. Com o escravo o caso é outro - é necessário contar com uma manutenção, tratamento durante as moléstias, velhice, capital empregado na compra, extinção desse por morte, obrigação de carregar com o mesmo ônus quer a colheita seja abundante ou pequena etc. Evidentemente, em tal fator encontra-se a explicação do alto custo de produção do café, e por conseguinte, a causa principal da crise atual; a supressão progressiva dessa forma de trabalho. Talvez seja o único meio eficaz de fazê-la cessar. Além de custosa, a mão de obra escrava é má. ${ }^{394}$

O texto acima reproduz o raciocínio de Couty sobre a má qualidade da mão de obra escrava, especialmente no aspecto que Couty relacionou, ou seja: o alto custo da produção do café tinha origem na má qualidade da mão de obra escrava. Esse argumento construía a necessidade da substituição dessa mão de obra de má qualidade e pouco abundante por uma mão de obra melhor. Nesse contexto, a inferiorização do trabalho do negro escravizado ganhava no Brasil, pela intervenção teórica de Couty, novos significados que eram assimilados na discussão da

394 O brado da lavoura, 29 ago. 1883. APESP: Ofícios Diversos (Mogi-Mirim), ordem 1121. Apud GONÇALVES, Paulo Cesar. Migração e mão de obra: retirantes cearenses na economia cafeeira do centro-sul (1877. 1901). São Paulo: Humanitas, 2006, p. 80. 
mão de obra naquele momento. Desse modo, suas ideias eram compartilhadas e amalgamadas aos interesses da substituição do escravo pelo trabalhador livre europeu.

A suposição de que o trabalho escravo era inferior ao trabalho livre vem da crítica dos economistas políticos à escravidão, que apareceu nos textos dos fisiocratas e teve continuidade em Adam Smith, se estendendo pela economia clássica. De modo geral essa corrente de pensamento baseava-se no princípio de que o trabalho escravo era o mais caro de todos. Esse princípio da inferioridade do trabalho escravo desdobrava-se em um conjunto de ideias como baixa produtividade do trabalho escravo, resistência do escravo ao trabalho, impossibilidades de inovações técnicas na organização escravista. ${ }^{395}$

Essa ideia econômica da inferioridade do trabalho escravo se formou ao mesmo tempo em que a ciência incutiu uma classificação racial dos povos. O momento pós-descobrimento do Novo Mundo marcou a vida da humanidade ao revelar novos povos que até então se mantinham distante do olhar europeu em seu devir colonizador. Na medida em que os europeus colonizadores passaram a narrar os outros povos que encontravam em

395 ROCHA, Antonio Penalves. A economia politica na sociedade escravista: um estudo dos textos econômicos de Cairu. São Paulo: Hucitec, 1996, p. 119. No caso brasileiro, como assevera Rocha, edificado sobre uma base escravista as ideias da Economia Política, gestada numa realidade europeia em que o trabalho livre se tornava dominante no mundo do trabalho, deveriam, por suposição, se opor ao antiescravismo da Economia Política. Contudo, "as ideias econômicas sobre a escravidão não só entraram no Brasil, como também aqui se acomodaram e, prestando serviços às representações dessa sociedade, chegaram até mesmo a justificá-la, sem que se desligassem formalmente da Economia Política”. p. 119. 
suas expedições, num processo de expansão, tais narrativas construíam o imaginário, dando uma "consciência planetária". ${ }^{396}$ Narrar, coletar, classificar tudo de um ponto de vista dos países centrais do processo de colonização do Novo Mundo era o mote da expansão. Nesse contexto, dois acontecimentos marcam o modo como o europeu vai estabelecer a base material e imaginária do que eles eram e de como eram os outros povos que no caminho fossem encontrados. Um acontecimento foi o tratado científico de Carl Linné, publicado em 1735. Nessa obra, Sistema Naturae, ele estabelece um sistema de classificação que visou categorizar todas as formas vegetais do planeta, fossem elas conhecidas ou desconhecidas dos europeus. Outro acontecimento importante para a análise do entendimento das formas que delinearam a organização social e sua imaginação do real foi a inauguração da primeira expedição científica internacional da Europa - conhecida como "La Condamine" -, um esforço conjunto visando determinar a forma exata da terra. Para Mary Pratt, estes dois eventos, e sua coincidência, sugerem a importante magnitude das mudanças no entendimento que as elites europeias tinham de si mesmas e de suas relações com o resto do mundo, ${ }^{397}$ ou do mundo que se criava na narrativa. Partia-se, portanto, com um método classificatório, a fim de descrever por comparação

\footnotetext{
396 Segundo Mary Pratt, “consciência planetária” é resultante da exploração dos países europeus pelo interior do Novo Mundo e da África, decorrendo uma construção do significado em nível global dessa ação por meio dos aparatos descritivos da história natural. Esta consciência planetária "é o elemento básico na construção do moderno eurocentrismo”. PRATT, Mary Louise. Os olhos do império: relatos de viagem e transculturação. Tradução de Jézio Hernani Bonfim Gutierre. Bauru: Edusc, 1999, p. 42.
}

397 PRATT, Mary Louise. Os olhos do império, op. cit., 1999, p. 42. 
o que fosse encontrado, tendo assim como referência o modelo europeu.

A obra de Carl Linné vai introduzir a classificação das pessoas, sendo o rótulo homo sapiens de sua autoria. ${ }^{398}$ No século XVIII, Linné hierarquizou os grupos humanos existentes em termos taxinômicos modernos. Em sua classificação e hierarquização o homo sapiens afer (negro africano) era governado pelo capricho; enquanto o homo sapiens europaeus era governado pelos costumes. ${ }^{399}$ Linné classificou o americano como amante da liberdade, governado pelo hábito e o asiático como melancólico, governado pela opinião e preconceitos. Outros caracteres que Linné atribuiu ao negro e ao branco cabem ser ressaltados. O negro, além de governado pelo capricho, ou seja, sem governo, necessitando ser governado, também era indolente, negligente. O branco, além de governado pelos costumes, era musculoso, engenhoso, inventivo. ${ }^{400}$

Essas características físicas, sociais, biológicas dos povos - especialmente as comparações entre negros e brancos - percorreu o século XIX, ápice do pensamento científico, acumulando novas caracterizações que em geral não fugiam do que propôs Linné no século XVIII. Nesse sentido, Louis Couty quando asseverava que o trabalho do negro era caro, que o negro com sua enxada não possibilitariam inovações, que o negro precisava ter seu

\footnotetext{
398 Idem, p. 68.

399 GOULD, Stephen Jay. A falsa medida do homem. Tradução de Valter Lellis Siqueira. 3. ed. São Paulo: Martins Fontes, 2014, p. 21.

400 MUNANGA, Kabengele. Uma abordagem conceitual das noções de raça, racismo, identidade e etnia. Palestra realizada no $3^{\circ}$ Seminário Nacional de Relações Racial e Educação - PENESB, 5 nov. 2003. Disponivel em: < https://www.ufmg.br/inclusaosocial/?p =59>. Aceso em: 18 ago. 2014.
} 
trabalho vigiado de forma constante, estava retomando as formulações de Linné adaptando-as na realidade brasileira. Em contrapartida, o trabalho do imigrante europeu seria a solução para a crise que advinha do trabalho escravo. E o mesmo se dava com sua visão da Lei do Ventre Livre (1871), uma lei baseada nos costumes dos homens que governavam o Império.

A construção textual de Couty insere-se nessa longa narrativa que, desde Linné, inferiorizou o negro sob dois pontos de vista: da Economia Política e da Ciêncial Biologia. Com efeito, nesse longo pensamento que intencionou inferiorizar o trabalho escravo, Couty, na realidade brasileira, atua por vias que ele construiu, entende-se aqui a disciplina de Biologia Industrial, em conjunto com suas ações como cientista e mediador cultural no amplo aspecto que esta mediação pode ser entendida, isto é: no campo material e intelectual de realizações. Na descrição que fez Couty dessa nova disciplina, apreendemos os meios que ele elaborou para refletir a realidade brasileira do século XIX. Mesclou elementos da economia, da ciência biológica, da fisiologia e forjou a Biologia Industrial, meio pelo qual operou na realidade brasileira as correntes de pensamento do Velho Mundo.

Para justificar a necessidade de substituir o escravo pelo imigrante europeu, elaborou uma interpretação de seu momento que tinha na ideia de Biologia Industrial o ponto chave que possibilitou a ele insistir na hipótese da inferioridade do trabalho escravo. De fato Couty não foi original em concluir que o trabalho escravo era inferior, com efeito, ele se insere numa longa tradição que elaborou teses que visavam classificar o negro escravizado como inferior, hierarquizando seu lugar na sociedade. Nessa longa tradição, Couty incutiu novos elementos 
atrelando reflexões da nascente sociologia a aspectos biológicos. Nesses termos asseverava Louis Couty, "seguindo a ideia muito verdadeira de Bacon, bem desenvolvida atualmente por Spencer, os corpos sociais são comparáveis a organismos vivos, todas as partes se ligam mais intimamente umas as outras, em medidas perfeitas". ${ }^{401}$

Nessa comparação do organismo social como organismo vivo, com suas doenças e lesões que comprometiam o pleno desenvolvimento, Couty elaborou uma ideia que colocava a mão de obra do negro africano como entrave para o desenvolvimento harmonioso da sociedade, posto que atrapalhava o desenvolvimento produtivo, sobretudo o desenvolvimento social. O negro seria uma lesão que impediria a saúde do corpo social. Não havia encaixe do trabalho do negro escravizado com uma produção uniforme, padronizada, posto que com um instrumento como a enxada o que poderia ser feito para aumentar e dar padrão de qualidade na produção?

Para justificar seu argumento recorria ao modo de análise que incutiu na Biologia Industrial. Assim, comparando com a fisiologia e medicina onde "não podemos estudar uma secreção normal ou mórbida” sem "reconhecer as diversas funções circulatórias ou nervosas que as regem”, entendia que o mesmo se daria com a Biologia Industrial. Com efeito, ao estudar a produção do café e encontrar seus problemas, suas lesões, tenta-se "considerá-lo em sua relação com o meio social”. Esse problema, ou mal, era "único” e "pode ser localizado na mão

\footnotetext{
401 COUTY, Louis. Étude de biologie industrielle sur le café, op. cit., 1883, p. 114.
} 
de obra". Esse mal "tem o nome de escravidão", logo o "escravo deve ser removido, ou antes, substituído". 402 Estava nisso "a verdadeira questão, a questão do Brasil neste fim de século, esta que resume a crise do café, e de outras dificuldades". Quanto a isso, segundo Couty, todo mundo sabia "e a necessidade de acabar o mais cedo com a escravidão" era "universalmente reconhecida”. ${ }^{403}$

Quando Couty diz acabar com a escravidão, ele não quer dizer abolição imediata, quer dizer imigração abundante somada à introdução de máquinas agrícolas, para que no correr breve do tempo não se perceba mais escravos trabalhando nas lavouras de café, pois só assim se daria a transição gradual por ele idealizada.

Em cada propriedade agrícola, a perda imposta ao senhor de escravos pelas depredações dos negros é considerável, principalmente nas fazendas de café. De nada vale trancar as senzalas durante a noite ou vigiar durantes o dia. Para roubar, o negro se torna industrioso e ativo, sabe dissimular e, no primeiro instante de liberdade, irá vender o produto de sua astúcia. ${ }^{404}$

Continuar com a mão de obra escrava diante de tudo que Couty apontou não seria a melhor solução para o futuro da lavoura cafeeira poderia pensar aqueles que compartilhavam das ideias de Couty. O trabalho e o comportamento do negro escravizado não teria correção ao olhar de Couty. Demandava um alto custo e os resultados produtivos não compensavam esse custo. Além

402 Idem, p. 114-115.

403 Idem, p. 115.

404 COUTY, Louis. A escravidão no Brasil, op. cit., 1988, p. 94. 
disso, se liberto fosse abandonaria o trabalho imediatamente, sobretudo porque, dizia ele anos mais tarde, "a própria libertação, apesar de seu propósito humanitário, em nada podia alterar os defeitos mentais e sociais dos atuais trabalhadores". ${ }^{405}$ Desse modo, Louis Couty estava reafirmando a necessidade da imigração ao descartar as possibilidades do negro evoluir e se adequar ao modo civilizado. Mostrava-se um ideólogo ativo da ideologia do branqueamento quando, com sua ciência, dizia ter os negros defeitos mentais inalteráveis.

\title{
4.5 A "falta de homens livres ativos"
}

\author{
Os homens livres da ordem escravocrata, ${ }^{406}$ que se \\ sentiam como "intrusos" no sistema como dizia Alfredo
}

\footnotetext{
405 COUTY, Louis. "Introdução”. In: O Brasil em 1884: esboços sociológicos, op. cit., 1984, p. 17.

406 Segundo a historiografia do assunto, constituídos à margem do sistema escravista deste o tempo da colônia, o contingente de homens livres recrudescia com processo abolicionista do século XIX. Assim, passavam distantes da disciplinarização do trabalho, ou seja, fora do binômio senhor e escravo. Com isso, se o referencial de trabalho era o do cativeiro, o entendimento que se tinha era de que a rejeição ao trabalho regular era porque todo e qualquer forma de trabalho manual era considerado como coisa de escravo e, portanto, degradante. KOWARICK, Lucio. Trabalho e Vadiagem: a origem do trabalho livre no Brasil. 2. ed. Rio de Janeiro - RJ: Paz e Terra, 1994, p. 43. Para uma discussão clássica do tema ver: FRANCO, Maria Sylvia de. Homens livres na ordem escravocrata. São Paulo: Editora UNESP, 1997. Gonçalves demonstra o papel da migração nordestina para a cafeicultura do centro-sul entre as décadas de 1870. GONÇALVES, Paulo Cesar. Migração e mão de obra: retirantes cearenses na economia cafeeira do centro-sul (1877-1901). São Paulo: Humanitas, 2006, p. 156.
} 
d'E. Taunay, ${ }^{407}$ era para Couty homens pouco ativos, descartados do seu pensamento, de seu projeto de colonização/civilização para Império. O trabalhador nacional é abordado em seu discurso como ilustração da necessidade da imigração e ao mesmo tempo torna-se ilustração da necessidade de uma abolição gradual. Nesses termos:

Foram realizadas tentativas de trabalho livre, em grande escala, mas, até agora, só se obteve sucesso em alguns serviços urbanos e em produções quase naturais como as da borracha, do tabaco, do mate e do cacau. Os progressos são efetivos, mas continuam sendo muito lentos em virtude da falta de homens livres ativos, aptos para os trabalhos agrícolas e capazes de uma atividade regular. ${ }^{408}$

Apesar de existir uma oferta de mão de obra livre, Louis Couty não entendia essa oferta de mão de obra constituída por homens ativos, ou seja, úteis no processo de abolição gradual proposto pela Lei do Ventre Livre (1871). Diante disso, se fosse abolida a escravidão em 1881, os fazendeiros não teriam mais como produzir diante da ausência de trabalho ativo disponível. Para Couty, os trabalhadores livres não realizavam uma atividade regular de trabalho; após certo período trabalhando não voltavam a trabalhar porque já se bastavam com o

407 Segundo Taunay, nas notas que fez em parceria com André Rebouças para o livro de Couty, o trabalhador nacional é vagabundo por não encontrar regalia alguma, "são homem oprimidos pela ideia de que são sempre intrusos e com justiça podem ser desalojados da terra que tem regado com seu suor. Daí a preguiça, o pouco amor ao local onde permanecem, mas que não the incute o sentido da estabilidade". COUTY, Louis. Pequena propriedade e Immigração Europeia, op. cit., 1887, p. 122. 408 COUTY, Louis. A escravidão no Brasil, op. cit., 1988, p. 51. 
que havia conseguido. Apesar de bons para obras difíceis e passageiras, "descansam quando têm algum dinheiro e não pensam em economizar" ${ }^{409}$ Outros empecilhos do uso do trabalhador livre se relacionavam à forma pela qual o trabalho escravo era visto pelos homens livres. Nesse sentido, "se o caboclo se recusa a dedicar-se a uma atividade agrícola regular, é porque não quer ser assimilado ao escravo". ${ }^{410}$ Inúteis no processo de organização do trabalho livre e no processo civilizador por qual passava o país, "Os caboclos, indolentes e apáticos, e os escravos precisam ser substituídos por trabalhadores diligentes, capazes de produzir, consumir e aproveitar as diversas facilidades das trocas. [...]". ${ }^{411}$

Ao mesmo tempo em que indicava um vácuo de produção ativa, indicava também quais elementos deveriam preencher esse espaço. Com isso, Couty mediava a organização do trabalho livre apontando um horizonte imigrantista. Seu trabalho ideológico nesse contexto foi suficientemente exitoso no ato de estabelecer os parâmetros do que precisava ser descartável e do que precisava vir e cobrir o que seria descartado no processo de organização do trabalho livre e, ao tempo, delineava, em bases científicas, um projeto civilizador imigrantista para o destino do país. O mais interessante em apontar no pensamento de Couty era no aspecto que ele não estava

409 COUTY, Louis. "Exploração e colonização”. (4 a 11 nov. 1883). In: O Brasil em 1884: esboços sociológicos, op. cit., 1984, p. 82.

410 COUTY, Louis. A escravidão no Brasil, op. cit., 1988, p. 88. Caboclo era um dos termos que Louis Couty utilizava para se referir aos homens livres nacionais.

411 COUTY, Louis. "As estradas de ferro". (6 jan. 1884). In: O Brasil em 1884: esboços sociológicos, op. cit., 1984, p. 170. 
pensando na mão de obra apenas, mas na constituição de um mercado interno de consumo, de um indivíduo que tinha necessidades, por isso os caboclos que se bastavam com o pouco que tinham não eram úteis nessa organização capitalista ${ }^{412}$ que se formava no Brasil. Além disso, os negros escravizados ao receberam a alforria não trabalhariam mais, ampliado o contingente de "vadios". Em seguida, dizia ele que:

O brasileiro verdadeiramente livre, aquele que pensa, que vota e que consome, representa uma pequena parte da massa da população; e em vez de ser lavrador, industrial ou artesão, ele visa a empregos políticos, administrativos ou outros que lhe pareçam mais importantes. É funcionário, médico ou engenheiro, é proprietário de escravos ou burocrata. ${ }^{413}$

Uma característica interessante que Couty atribui ao brasileiro verdadeiramente livre é a de que ele consome, que tem necessidades. ${ }^{414}$ Diferentemente ele vai

412 Segundo Kowarick, A apropriação de meios e instrumentos de produção, ao gerar lucros por meio da fabricação de bens para o mercado de consumo, constitui condição necessária para o surgimento do capitalismo. Contudo, para a realização disso, esses processos de produção precisam estar articulados de modo a criar excedentes mediante uma modalidade específica de subjugar o trabalhador. KOWARICK, Lucio. Trabalho e Vadiagem: a origem do trabalho livre no Brasil 2. ed. Rio de Janeiro - RJ: Paz e Terra. 1994, p. 11.

413 COUTY, Louis. "Exploração e colonização". (4 a 11 nov. 1883). In: O Brasil em 1884, op. cit., 1984, p. 80.

414 Segundo Berman, no século XIX, à medida que o mercado internacional se expandia, absorvia e destruía os mercados locais, com isso: "produção e consumo - e necessidades humanas - tornam-se cada vez mais internacionais e cosmopolitas”. BERMAN, Marshal. Tudo o que é sólido desmancha no ar, op. cit., 2013, p. 113. 
caracterizar a camada que ele não considera como cidadãos como sendo uma população que vive sem necessidades. Na medida em que se consome seria necessário uma produção ativa capaz de suprir as necessidades, do contrário ao se bastar com o pouco que tem não é interessante no desenvolvimento do país. Pensa ele num mercado interno ausente, que precisa ser desenvolvido e interligado ao mercado internacional, sendo isso um dos problemas do Brasil. A necessidade é o motor do progresso, da civilização, aquele que consome esta no topo, movimenta o mercado. Do outro lado estaria, para Couty, a população desajustada do sistema produtivo.

A presença dos escravos e junto deles vários milhões de camponeses, caboclos ou antigos agregados, sem atividade e necessidades, que ainda não são cidadãos úteis, pois não votam e não trabalham de maneira contínua, são a verdadeira causa da ausência de riqueza de valor das culturas e também da insuficiência dos impostos e das exportações. [...]. ${ }^{415}$

Analisando a sociedade de modo vertical, do escravo ao fazendeiro, notava Couty que a população brasileira possuía aproximadamente doze milhões de habitantes, sendo um milhão de índios e um milhão e meio de escravos. Restavam aproximadamente nove milhões de habitantes dos quais quinhentos mil era composto pelas famílias proprietárias de escravos: fazendeiros, advogados, médicos, funcionários, administradores, comerciantes.

415 COUTY, Louis. "Exploração e colonização”. (4 a 11 nov. 1883). In: O Brasil em 1884, op. cit., 1884, p. 80. [grifo nosso]. 
O grande problema para Couty estava nos seis milhões restantes, na população livre que, segundo ele, não era suficientemente preenchido. Eram seis milhões de habitantes que: "no mínimo, nascem, vegetam e morrem sem ter servido ao país". No campo, dizia ele "serão agregados de fazenda, caboclos, caipiras; nas cidades, capangas, capoeiras ou simplesmente preguiçosos e beberrões [...]". ${ }^{416}$

A verdadeira dificuldade de transformar o trabalho e aumentar a consequente produção não estaria na emancipação dos negros, mas sim na dificuldade em formar trabalhadores livres ativos. Na visão de Couty o contingente de homens livres "são menos que cidadãos, pois não são nem eleitores, nem consumidores, nem produtores". ${ }^{417}$ Era um povo improvável, não se daria como povo, seria um elemento não útil, que atrapalharia o amalgama social. Louis Couty pensava nas necessidades que fomentavam o mercado interno e externo e para isso era preciso um grupo social habilitado a produzir e, especialmente, a consumir. Sem consumo não há produção, sem produção não há progresso, sem progresso não há desenvolvimento científico, não há ciência.

Numa tentativa retórica de solucionar o problema dessa população marginalizada, Couty propõe dar aos 8 milhões de habitantes livres do Brasil a atividade dos habitantes dos Estados Unidos e Austrália "para que todas as dificuldades atuais fossem mais ou menos resolvidas". Contudo, observa o cientista que isso "não é possível porque não se muda a conformação dos cérebros e só

416 COUTY, Louis. A escravidão no Brasil, op. cit., 1988, p. 102.

417 COUTY, Louis. "Exploração e colonização”. (4 a 11 nov. 1883). In: O Brasil em 1884, op. cit., 1984, p. 81. 
lentamente se modificam os costumes de um povo". Assim, é necessário procurar "remédios mais rápidos", 418 ou seja, era preciso a transformação pela imigração europeia. A cada argumento Couty estabelecia uma ordem de como deveria se dar o progresso do Brasil, nesse processo o negro e o mestiço não teriam condições de serem assimilados numa conformação social útil ao destino do país porque para Couty a conformação do cérebro não se alterava. Daí a necessidade de branquear o país pela imigração europeia.

\subsection{0 imigrante europeu, o futuro}

O país que Louis Couty encontrou em 1879 era o país da escravidão. Até então, as primeiras experiências de uso do trabalho imigrante não haviam surtido bons resultados. ${ }^{419}$ Embora o malogro da experiência com o trabalho livre tivesse gerado restrições em países que enviavam contingentes de imigrantes para o Brasil, a vontade de atrair imigrantes para substituir o escravo continuava.

\footnotetext{
418 Idem, p. 80.

419 A primeira experiência do uso do trabalhador imigrante na produção cafeeira deu-se nas fazendas Ibicaba e Angélica, ambas as propriedades do Senador Vergueiro. Contudo, conflitos entre proprietário e colonos desencadeou o fim da experiência. Para uma compreensão do periodo e de outras experiências há uma ampla produção que tratou do assunto. Cf. HOLANDA, Sergio Buarque de. "Introdução". In: DAVATZ, Thomas. Memórias de um colono no Brasil. Belo Horizonte: Editora Itatiaia; São Paulo: Edusp, 1980. COSTA, Emilia Viotti. Da Senzala à Colônia. 2. ed. São Paulo: Ciências Humanas LTDA, 1982. STOLCKE, Verena; HALL, Michael M., "Introdução do trabalho livre nas fazendas de café de São Paulo”. In: Revista Brasileira de História, n. 6 , set. 1983.
} 
Com a década de 1870 inaugura-se uma nova fase na política imigratória brasileira: "a dos grandes contratos para a introdução de europeus”. Depois disso, o processo recrudesce até as grandes levas após meados da década de $1880 .{ }^{420}$

As reflexões de Louis Couty sobre o trabalho do imigrante tiveram como exemplo prático o que estava sendo feito na província de São Paulo. Embora Couty idealizasse também outros meios de atrair o imigrante, a experiência realizada pelos fazendeiros de São Paulo o agradava muito. Constantemente recorreu às ações que os fazendeiros paulistas estavam praticando para exemplificar que de fato, como ele pensava, "se o Brasil quer progredir só tem uma solução, a utilização da mão de obra livre fornecida pela Europa”. Não haveria outra solução e todos reconheciam que "somente a Europa pode fornecer ao Brasil esta mão de obra que falta”. ${ }^{421}$

Se as ideias de Couty sobre o "inferior" trabalho escravo eram analisadas e repercutidas na grande imprensa, suas ideias sobre o "superior" trabalho do imigrante também ganhavam os espaços dos jornais.

Provado como ficou no artigo precedente, graças aos dados fornecidos pelo trabalho do Dr. Couty, que a mão de obra escrava só deixa, ao produtor de café, lucro insuficiente - vamos tentar a demonstração inversa para a mão de obra livre,

420 GONÇALVES, Paulo Cesar. Mercadores de Braço: riqueza e acumulação na organização da emigração europeia para o novo mundo. São Paulo: Alameda, 2012, p. 149.

${ }^{421}$ COUTY, Louis. Étude de biologie industrielle sur le café, op. cit., 1883, p. 126-127. 
estudando a colonização tão ativa e, no entanto, tão ignorada, da província de S. Paulo. ${ }^{422}$

Com essas repercussões dos estudos de Louis Couty, o argumento favorável ao imigrante europeu tornava-se cientificamente comprovado. Nesse sentido, todo o percurso que Couty realizou para estudar o café e o trabalho empregado em sua produção, seus lugares de ação, seu capital científico, estavam pesando em seu argumento. Era a autoridade conceitual no assunto. ${ }^{423} \mathrm{O}$ artigo da Gazeta de Notícias se baseou no relatório sobre o café de 1883, sendo o artigo pouco posterior à publicação do relatório. Para tanto, os dados resultantes da comparação que Couty realizou entre o trabalho escravo e o trabalho livre serviram de fundamentação para o autor do artigo corroborar a superioridade do trabalho do imigrante europeu e, sobretudo, a necessidade de uma corrente imigratória para o Brasil.

Seguindo os dados fornecidos por Couty, o autor da Gazeta de Notícias asseverava que a província de São Paulo teria 30 mil colonos de fazenda. Eram colonos que

422 Gazeta de Notícias, 30 ago. 1883. Apesar de não constar autor, o título do artigo era "Vantagens do colono". Todavia, tudo indica que o autor do artigo "Vantagens do colono" é o mesmo que analisou o trabalho de Louis Couty no artigo "Inferioridade econômica do escravo". (21 ago. 1883).

423 Em uma nota a Gazeta da Tarde (29 de setembro de 1884) traz uma informação interessante de Couty na seção "Dia a Dia" da folha: "Consta que S. Ex. [Couty] vai ser, ou já está nomeado agente de colonização”. Em menos de dois meses dessa nota Couty morreria e talvez por isso não encontramos nenhuma outra informação sobre essa nomeação de Couty para a função de agente de colonização. Mas cabe ressaltar que essa nomeação de Couty demonstra que o que ele pensava estava sendo levado em consideração pelas autoridades do governo. 
ocupavam as terras cultivadas que, para Couty, seria de início a melhor colocação do colono recém-chegado da Europa. Com esses dados, segundo a Gazeta de Notícias, Couty "patenteia as vantagens que colhe o fazendeiro, substituindo o homem livre ao escravo". ${ }^{424}$

Enquanto que a produção escrava da região de Campinas e Limeira fornecia em média "60 mil arrobas por mil pés”, a produção colona seria “de cem arrobas por mil pés”. Com a mão de obra imigrante o cenário de aumento da produção estaria claro para o autor da Gazeta de Noticias:

Ao passo que um hectare de cafeeiro rende de $200 \$$ a $400 \$$ nas mãos dos escravos, rende de $500 \$$ a $600 \$$ com o colono; e a cultura do café mostra-se superior, não só aos cereais e à vinha, mas também à do açúcar, do algodão etc. ${ }^{425}$

Esses dados de Louis Couty, que o autor da Gazeta de Notícias utilizou para mostrar as vantagens do colono europeu, baseado nos exemplos práticos da província de São Paulo, demonstram que a repercussão e recepção dos argumentos de Couty sobre a superioridade do trabalho imigrante já faziam dele uma referência conceitual no assunto da mão de obra.

As ações e ideias de Louis Couty, seus textos e debates, constituíram, ao intervir, o contexto do amplo debate sobre a mão de obra na década de 1880, década que marcou o fim do regime monárquico e registrou uma

${ }^{424}$ Gazeta de Notícias, 30 ago. 1883.

425 Idem. 
forte corrente de imigrantes para o Brasil. Sua intervenção na questão da mão de obra se deu pelo modo que ele caracterizou a Biologia Industrial. Esta caracterização instrumentalizou sua ação e garantiu sensivel recepção nesse amplo debate. Se o Brasil não quer permanecer parado, "se quer fazer rapidamente sua emancipação, sem prejuizo para as culturas e exportações, se quer fazer cessar a crise do café, é urgente que prepare uma imigração mais ativa”. ${ }^{426}$ Nesses termos, Louis Couty tencionava unicamente a imigração, não pensava a emancipação dos negros senão em termos de perdas de produção, não cogitava o trabalho do negro como elemento ativo, apenas como elemento secundário no processo. Era o imigrante o único meio capaz de tirar o Império da crise. Posto que: "A imigração permite a cicatrização rápida da ferida da escravidão, como também permitirá aumentar, mais tarde, produções de café, de açúcar e de algodão que, já por falta de mão de obra, começam a diminuir". 427

\section{7 "O lado futuro do passado": Ces Yankees du Brésil428}

Felizmente, como a imigração já havia começado, pude convencer-me de que esta forma de colonização da terra cultivada era realmente adequada

${ }^{426}$ COUTY, Louis. Étude de biologie industrielle sur le café, op. cit., 1883, p. 160 .

427 COUTY, Louis. "A colonização e o estado”. (3 jan. 1884). In: O Brasil em 1884, op. cit., 1984, p. 148.

428 Segundo Louis Couty, "Yankees do Brasil" era a forma pela qual os paulistas se autodenominavam. Étude de biologie industrielle sur le café, op. cit., 1883, p. 129. 
ao percorrer as fazendas da inteligente província de São Paulo. ${ }^{429}$

Apesar de acreditar do potencial da imigração europeia, era preciso exemplos vivos e claros para que não houvesse argumentos contrários e para isso a imigração na província de São Paulo servia a Couty como um feliz convencimento. Os paulistas, segundo os cálculos de Couty, não se limitaram em triplicar em menos de vinte anos suas plantações de café, em cobrir a província de meios perfeitos de trabalho, de engenhos de café, de açúcar, manufaturas de algodão e de diversos produtos. Os paulistas não se limitaram "a construir em dez anos aproximadamente 1.500 quilômetros de ferrovia”. Sem a ajuda do governo imperial, enfatizava o francês, estes paulistas, "por própria iniciativa" encontraram uma maneira de substituir o negro pelo branco, l'homme libre à l'esclave. Num fôlego de modernidade e transformação, os paulistas, "pegaram o problema em sua base e levaram a província a se aproximar do fim do uso da mão de obra escrava" ${ }^{430}$

Nesse percurso - regiões cafeeiras do Vale do Paraíba e Oeste Paulista - em que desconstruía em bases escravistas para em seguida reconstruir em bases de trabalho livre a produção cafeeira e o Brasil, Couty fundamentava seu pensamento sobre a realidade do Império. Nessa fundamentação, esteve ele muito próximo dos principais

${ }^{429}$ COUTY, Louis. “Introdução”. In: O Brasil em 1884: esboços sociológicos, op. cit., 1984, p. 17.

${ }^{430}$ COUTY, Louis. Étude de biologie industrielle sur le café, op. cit., 1883, p. 129. 
fazendeiros paulistas, os fazendeiros do futuro como ele mesmo dizia.

Devo à gentileza de Soares Brandão, presidente da província; devo aos cuidados de homens como Tibiriçá, Antonio Prado, o Visconde de Indaiatuba, o Barão de Parnahyba, Vergueiro, Ferreira Camargo, de poder reunir sobre a colonização em São Paulo as observações numerosas e precisas que posso resumir: elas formam a parte verdadeiramente útil desta viagem, que deram a este relatório uma conclusão lógica, mostrando o lado futuro do passado. ${ }^{431}$

Os fazendeiros do passado e os fazendeiros do futuro representavam os dois lados de uma mesma moeda, uma moeda quase dividida diante das ações de um lado que permanecia prolongando o passado e do seu outro lado alcançando o futuro. Uma moeda cara e rara no lado passado, uma moeda rica em vias de tornar-se abundante na medida em que as ações seguiam os propósitos imigrantistas no lado futuro. No presente de Couty e de seus coevos podemos visualizar um esquema de temporalidades que relacionava o negro africano escravizado e o grande proprietário do vale do Paraíba com o passado, enquanto que o imigrante europeu que viria para trabalhar na pequena propriedade estaria relacionado com o futuro. Nesse sentido, a província de São Paulo representava o exemplo mais bem acabado do projeto idealizado por Louis Couty.

Para Couty, na crise atual, São Paulo "tem a certeza de poder atravessar" sem se arruinar, enquanto as

431 Idem, p. 129 
demais províncias se "organizam e se agitam". Estava aos olhos de todos que São Paulo era "o exemplo certo a seguir e o Brasil não tem necessidade de copiar países estrangeiros, como tenta frequentemente fazer: já encontra aqui mesmo seu próprio modelo" ${ }^{432}$ Numa crítica ao modo de conduzir a imigração por parte do Ministério da Agricultura, Couty notava que a província de São Paulo "soube corrigir os erros do governo geral". ${ }^{433}$

A província de São Paulo em suas ações tornava-se uma referência de como deveria ser conduzida a imigração no Brasil. Para Couty, a província de São Paulo "soube simultaneamente começar a construção de estradas de ferro e engenhos e povoar suas terras; ela possui uma produção e uma tecnologia importantes”. Nas demais províncias, Couty notava que "a iniciativa privada limitou-se quase que exclusivamente a instalar culturas e criações de animais, como no tempo dos portugueses, pautadas na escravidão e na grande propriedade". ${ }^{434}$ Enquanto São Paulo avançava rumo ao futuro, as demais províncias continuavam prolongando o passado. Os fazendeiros destas províncias, os fazendeiros do passado,

432 COUTY, Louis. "O Brasil no interior e os clubes da lavoura". (1 a 5 jun. 1884). In: O Brasil em 1884, op. cit., 1984, p. 249. Segundo Wilma Peres Costa, "as duas décadas finais da monarquia não foram um período de crescimento econômico, se considerarmos o país como um todo. A cafeicultura paulista e a exportação de borracha crescem em um cenário geral de estagnação". COSTA, Wilma Peres. "A questão fiscal na transformação republicana - continuidade e descontinuidade”. In: Economia e Sociedade, Campinas, n. 10, 1998, p. 143.

433 COUTY, Louis. "A colonização e o governo". (13 set. 1883). In: O Brasil em 1884, op. cit., 1984, p. 22.

${ }^{434}$ COUTY, Louis. "Hipoteca e exploração". (20 a 27 set. 1883). In: O Brasil em 1884, op. cit., 1984, p. 77. 
insistiam no "regime colonial português", que segundo Couty era "o pior dos regimes econômicos". Trabalhando as dimensões da crise e do atraso do Brasil, Couty atribuía ao colonizador português as mazelas consequentes de seu ato de trazer o negro africano e a escravidão para o Brasil. 435

Louis Couty comparou as províncias de São Paulo e Buenos Aires, sendo sua finalidade demonstrar que São Paulo era a melhor e a mais ativa em produção do que a província platina. Era mais um exemplo bem-sucedido da ação modernizante e civilizatória do imigrante europeu.

As promessas são às vezes difíceis de cumprir. Ao falarmos sobre o recenseamento da Província de Buenos Aires, tínhamos nos comprometido a demonstrar que aquela província tão florescente e progressista equivalia no Brasil, à de São Paulo. Estávamos enganados. São Paulo não é apenas equivalente a Buenos Aires; é superior em todos os aspectos. [Sic.] ${ }^{436}$

Tanto São Paulo quanto Buenos Aires e toda a produção que delas adivinham eram a demonstração que o Brasil deveria seguir o modelo imigrantista. Essa análise de Couty tornou-se muito importante para a imagem da província de São Paulo e do Brasil no exterior. Nesse sentido, Couty não poderia prever que seu livro, O Brasil em 1884, seria utilizado pela Sociedade Central de Imigração

435 COUTY, Louis. "Riqueza e trabalho". (18 nov. 1884). In: O Brasil em 1884, op. cit., 1984, p. 93.

436 COUTY, Louis. "São Paulo e Buenos Aires: comparação entre as duas províncias”. (14-17-21 fev. 1884). In: O Brasil em 1884: esboços sociológicos, op. cit., 1984, p. 151. 
a fim de contrapor os argumentos negativos sobre a produção cafeeira e o seu destino incerto descrito pelo holandês Delden Laerne em seu livro, porém o melífluo discurso de Couty se acomodou ao discurso da Sociedade Central de Imigração e engrossou o coro contra Van Delden.

Os dados falavam por si:

A produção do café em São Paulo multiplicou-se por seis em menos de 20 anos e quadruplicou desde 1872. Enquanto isso, a produção mais importante de Buenos Aires, a lã, nem mesmo dobrou, elevando-se de 69 milhões de quilogramas em 1870 a 92 milhões em 1880 e a 103 milhões $1881 .^{437}$

A província de São Paulo, as ações que nela estavam realizando seus principais cafeicultores e os resultados conquistados, ocupou lugar estratégico no projeto imigrantista que advém das ideias de Louis Couty quando apreendemos suas ideias num conjunto estruturado.

Em seu percurso pela região cafeeira do Rio de Janeiro e São Paulo evidenciou o que estava ocorrendo e as direções tomadas diante das ações empreendidas. Enquanto uma parte, especialmente, a região do Vale do Paraíba fluminense, se organizava em bases escravistas sem maiores medidas para uma alteração, a produção cafeeira do Oeste Paulista estava atribuindo "pesos equilibrados à relação entre o homem e o solo”, modificando a base do povoamento agrícola, "substituindo os precários e insuficientes organismos de produção por outros mais ativos e melhor organizados", sobretudo atraindo

437 Idem, p. 155. 
imigrantes. No pensamento de Couty, só haveria uma forma para realizar e espraiar tal obra, esta transformação necessária "só seria realizável com a imigração", ${ }^{438}$ só com a imigração o Império teria uma condição de civilização, só assim teria um povo verdadeiramente ativo.

\section{8 "'O Brasil não tem povo!'. É duro; mas é verdade"}

"Ainda a pouco um esperançoso escritor estrangeiro, aliás, nosso amigo, escreveu isto: 'a situação funcional da população brasileira pode ser expressa em uma só palavra: o Brasil não tem povo!' É duro; mas é verdade"439 dizia Sílvio Romero, um dos mais icônicos membros da geração intelectual de 1870, a respeito da formulação de Louis Couty. Partilhava Romero da opinião de Couty, enfatizando a necessidade de lutar para alterar esse problema, posto que a "questão não é só produzir café”, dizia ele, “Já é tempo de olharmos para traz, lançar as vistas sobre o caminho percorrido a quatrocentos anos e conhecermos que pouco, bem pouco, temos feito como nação culta” ${ }^{440}$

Louis Couty também lutava para a alteração desse problema, seu foco era alijar essa população, colocando-a em funções secundarias e entregar aos imigrantes a função de elevar o país à civilização. Buscando na história a explicação dessa ausência de povo, dizia Couty que com

438 COUTY, Louis. "Introdução”. In: O Brasil em 1884: esboços sociológicos, op. cit., 1984, p. 17.

439 ROMERO, Sílvio. "Introdução à história da literatura brasileira”. In: Revista Brazileira, tomo 9, p. 293, set. 1881.

440 Idem, p. 293. 
a independência o Brasil "infelizmente" daria continuidade aos desmandos da metrópole. E com isso, "este País imenso, desabitado, inexplorado, continuou fechado ou dificilmente acessível aos colonos livres da Europa, os únicos que seriam capazes de formar um povo e, com um povo, uma riqueza duradoura e produtiva" ${ }^{441}$ Couty também estava criticando a colonização portuguesa que havia legado ao Brasil "o pior dos regimes econômicos que jamais existiu num país novo: o regime colonial português". ${ }^{442}$

Nas discussões sobre o destino do país que marcaram as décadas de 1870 e 1880, a crítica à colonização portuguesa espraiou-se. Joaquim Nabuco nesse momento notava que "no princípio da nossa colonização, Portugal descarregava no nosso território os seus criminosos, as suas mulheres erradas [...]". ${ }^{443}$ Nesse momento, esses homens estavam elaborando o futuro do país e o exemplo de Portugal, a obra portuguesa, não deveria, em hipótese alguma, ser seguida na continuidade da história do Brasil. Era preciso rechaçar todas as possiveis continuidades, para que o Brasil, assim, alcançasse a civilização. Todos queriam a abolição da escravidão, mas cada um a sua maneira.

$\mathrm{Na}$ constituição dos elementos que formariam o povo brasileiro, Couty, ao analisar a situação do negro liberto, notava que o negro deixou de ser escravo, "mas não se tornou um cidadão verdadeiramente livre e útil”. ${ }^{444}$ Nessa análise racial do negro, Couty colocava toda

441 COUTY, Louis. A escravidão no Brasil, op. cit., 1988, p. 60. [grifo nosso] 442 COUTY, Louis. "Riqueza e trabalho". (18 nov. 1884). In: O Brasil em 1884, op. cit., 1984 , p. 93.

443 NABUCO, Joaquim. O abolicionismo, op. cit., 2000, p. 98.

444 COUTY, Louis. A escravidão no Brasil, op. cit., 1988, p. 64 
sua verve de cientista imbuída nas teorias racialistas que compunham as correntes de pensamento que revoava Império a fora. ${ }^{445}$

Couty argumentava em cima de uma condição prévia, a de que o escravo era inferior, sendo ausentes qualidades que só eram encontradas nos europeus. Hierarquizava-se a sociedade e justificavam-se lugares sociais preestabelecidos.

O difícil pagamento de impostos pouco elevados, as flutuações do valor do papel-moeda, a lentidão dos processos do aparelhamento nacional, as dificuldades para a imigração, a ausência de um povo efetivamente produtivo, em suma, todos os problemas econômicos especiais com os quais se preocupam, e com razão, os estadistas brasileiros, admitem, em grande parte, a mesma causa: a presença do escravo. ${ }^{446}$

\footnotetext{
445 Segundo Carula, "No século XIX, os discursos racialistas fizeram parte das abordagens de diversos pensadores das ciências naturais e sociais. Fosse pelo viés monogenista ou pelo poligenista, os trabalhos analisavam os meios natural e social, hierarquizavam a humanidade segundo critérios marcados pelo olhar europeu (ou simplesmente ocidental), branco e masculino. A existência de raças superiores e inferiores era comprovada por meio do discurso cientifico/cientificista, que vinha como portador da verdade inconteste”. CARULA, Karoline. Darwinismo, raça e gênero: conferências e cursos públicos no Rio de Janeiro (1870-1889). São Paulo: Tese (Doutorado em História Social) Departamento de História/FFLCH USP, 2012, p. 125-126.

446 COUTY, Louis. A escravidão no Brasil, op. cit., 1988, p. 87. [grifo nosso]. Segundo Gould, "Os deterministas muitas vezes invocam o tradicional prestígio da ciência como conhecimento objetivo, livre de qualquer tipo de corrupção social e política. Eles pintam a si mesmos como os detentores da verdade nua e crua e a seus oponentes como sentimentais, ideólogos e sonhadores. [...]”. GOULD. Stephen Jay. A falsa medida do homem. Tradução de Valter Lellis Siqueira. 3. ed. São Paulo: Martins Fontes, 2014, p. 4.
} 
Com isso dado, para justificar seu argumento de que não seria tão simples a assimilação de todas as raças humanas e fazê-las "desempenhar o mesmo papel social”, Couty evocava os fatos fornecidos por Huxley, Haeckel, Broca, Quatrefages e Hamy. ${ }^{447}$ Isto é, a causa era o escravo, mas sua liberdade não seria a solução para o país, pois o negro para Couty era incapaz de reconhecer os princípios da civilização. Para tanto, recorre à descrição de um encontro que ele e seu amigo Goffredo Taunay tiveram com um velho escravo que dizia ser um príncipe congolês.

Isto que nos foi dito por este filho de rei que passara mais de meio século no seio de uma sociedade civilizada, poderia nos ter sido dito por qualquer um de seus companheiros de cativeiro. Nenhum deles imagina, via de regra, que poderia ter tido uma vida diferente. Falar com eles em hebreu ou sânscrito seria tão difícil quanto fazer com que ele compreendesse, em pouco tempo, que poderiam ser elementos ativos de uma sociedade civilizada. ${ }^{448}$

Couty procurava demonstrar com o exemplo do africano escravizado que havia uma naturalização da ideia de ser escravo entre os negros. O escravo não concebia outra situação que não aquela. O príncipe, por exemplo, não entendia que poderia ter outra situação de vida e por isso não se queixava da "perda da liberdade ou a sua venda como escravo", sua queixa era contra seu primeiro senhor, considerado por ele como "violento e

${ }_{447}$ COUTY, Louis. A escravidão no Brasil, op. cit., 1988, p. 89. 448 Idem, p. 91 
brutal". Sendo o príncipe pouco interessado na liberdade - dos europeus. ${ }^{449}$

Esta liberdade, que outros indivíduos desejam tão avidamente a ponto de não hesitarem em transformar toda uma situação social para poderem consegui-la, os próprios negros a desejam sem paixão, e, para conquistá-la, quase todos se recusam a realizar qualquer esforço [...]. ${ }^{450}$

Desse modo, para Couty os negros escravizados desconheciam qualquer forma de instituições civilizadas. Por não ter os negros hábitos e costumes civilizados, não seriam eles aptos a constituir uma população ativa no Brasil. Além disso, dizia que o negro "não tinha noção de família nem de propriedade", ${ }^{451}$ elementos importantes na constituição da tão desejada civilização. Contudo, Couty observava que sob vigilância o negro trabalha arduamente, da mesma forma, a mãe negra, apesar de nem saber quantos filhos possui e de não visitá-los, alimenta-os com dedicação enquanto pequenos. ${ }^{452}$ Por outro lado, "nas famílias de colonos europeus, as mulheres desempenham um papel verdadeiramente civilizador juntando-se aos trabalhos na roça, especialmente na colheita”. 453

\footnotetext{
449 Idem, p. 91.

450 Idem, p. 91.

451 Idem, p. 95.

452 Idem, p. 95-96.

${ }^{453}$ COUTY, Louis. Étude de biologie industrielle sur le café, op. cit., 1883 , p. 121. O discurso científico procurava impor padrões de civilidade e à mulher caberia função estratégica na preservação, manutenção e busca da civilização. A respeito do papel civilizador da mulher pelo olhar dos médicos e cientistas Cf. CARULA, Karoline. Darwinismo, raça e gênero, op. cit., 2012.
} 
Ressaltava a importância do imigrante, sobretudo da mulher no seio familiar, demonstrando aspectos civilizados que justificavam a vinda do imigrante. O argumento do branqueamento da população seria, para Couty, um fator importante para o progresso do país, sobretudo porque, com o imigrante, a obra da civilização dar-se-ia tanto na casa com a mulher, quanto no trabalho com o homem.

A visão de Couty, e de muitos que com ele compartilhavam a ideia da inferioridade do negro, se estruturava no fato de que o negro era inferior, sendo isto um dado inquestionável para a ciência e para a sociedade de um modo geral. As doutrinas racialistas envolviam alguns pressupostos específicos, que visavam afirmar que os homens se diferenciavam em grandes grupos, as raças, os quais possuem certa unidade que lhes conferem determinadas características. Para alguns racialistas, a distância entre as raças era tão grande que as configuraria como espécies diferentes. ${ }^{454}$ Assim, Couty entrava nessas questões com o enunciado proposto de que o negro era inferior e todos os seus cálculos tinham que mostrar isso. Uma vez que, "a maior parte dos negros adultos apresenta muitas das características das crianças de nossas sociedades civilizadas". ${ }^{455}$ Demonstrar que o negro era uma criança grande se tornou recorrente no contexto do século XIX ${ }^{456}$ Contudo, "esta criança é demasiado velha

454 MAIO, Marcos Chor; SANTOS, Ricardo Ventura. Raça como questão: história, ciência e identidades no Brasil. Rio de Janeiro: FIOCRUZ, 2010, p. 29.

455 COUTY, Louis. A escravidão no Brasil, op. cit., 1988, p. 96.

${ }^{456}$ GOULD. Stephen Jay. A falsa medida do homem. Op. Cit. Segundo Gould, o anatomista francês Etienne Serres na década de 1860 "tratou de provar a existência de sinais de inferioridade entre as raças 
para que se possa transformá-la em pouco tempo”. Desse modo, Couty queria anular qualquer possibilidade de utilização do negro tanto como mão de obra, quanto como povo útil. Seria um risco, para Couty, utilizar o negro como elemento constituinte do que viria a ser o povo brasileiro, posto que "o fato de seus caracteres étnicos e sociológicos serem comparáveis aos de nossa primeira evolução não impede que estes sejam traços definidos e imutáveis, que exigem várias gerações para poderem se modificar". ${ }^{457}$ Isto é, não havia tempo suficiente para esperar o aperfeiçoamento do negro ou do mestiço. No seu diagnóstico, o Brasil só sairia da crise se utilizasse outro elemento em sua estruturação social, o branco europeu.

O pressuposto das diferenças raciais se organizou no século XIX em oposição à visão Iluminista de uma humanidade unitária. Como assegura Schwarcz, a ideia de raça no final do século XIX se aproximava à noção de povo. Desse modo, o discurso racial aparecia como variante do debate sobre a cidadania, já que no interior desses novos modelos discorria-se mais sobre determinações do grupo biológico do que sobre o arbítrio do indivíduo, entendido como um resultado de sua raça. ${ }^{458}$

primitivas. Como anatomista, procurou essas provas no domínio de sua especialidade e confessou que não era fácil especificar critérios e dados. Ele se contentou com a teoria da recapitulação, segundo a qual as criaturas superiores passam, durante seu processo de crescimento, por vários estágios que correspondem aos dos animais inferiores. Os negros adultos, afirmava ele, corresponderiam às crianças brancas, e os mongólicos adultos aos adolescentes brancos. [...]”, op. cit., p. 27. 457 COUTY, Louis. A escravidão no Brasil, op. cit., 1988, p. 97.

458 SCHWARCZ, Lilia Moritz. O espetáculo das raças, op. cit., 2008, p. 47. 
O indivíduo seria determinado pelo grupo racial a qual pertence. $^{459}$

$\mathrm{Na}$ divisão dos capítulos de seu livro O Brasil em 1884, o último capítulo justifica-se pelo nome: O futuro. O primeiro artigo do capítulo também: Revolução, evolução, ação. Nesse artigo Couty faz uma análise do indivíduo a partir do que ele chamou de "duas grandes doutrinas", que se dividiam e dividia o mundo do pensamento. Para "os espiritualistas", o pensamento deriva de uma força imaterial, "cuja gênese e regras escapam aos nossos meios de investigação”. Esta força é chamada "de alma", oriunda de outra mais ampla: "a divindade". Esta divindade, dizia Couty, é dotada "de atributos ainda mais obscuros, o bem, o belo, a pré-ciência”. A este lado, estavam os homens que no Brasil "proclamam em alto e bom som o direito dos escravos à libertação, esquecendo que os negros são escravos na África, em seus países de origem, ligam-se à escola espiritualista e metafísica que busca numa autoridade suprema invisivel, insondável e indemonstrável o alvo das ações do homem”. Couty tenciona demonstrar, à sua visão, que se os abolicionistas "fossem lógicos e consequentes, sua divisa deveria ser: sucumba o Brasil e não um princípio". ${ }^{660}$

Do outro lado, de sua análise, estavam os materialistas que afirmam que "todos os fenômenos físicos, biológicos ou sociológicos são da mesma natureza”. Dessa corrente originava o materialismo científico que

459 MAIO, Marcos Chor; SANTOS, Ricardo Ventura. Raça como questão, op. cit., 2010, p. 29.

460 COUTY, Louis. "Revolução, evolução, ação”. (17 abr. 1884). In: O Brasil em 1884, op. cit. 1984, p. 237-238. 
"tomou outras formas mais insidiosas". Enquanto "Claude Bernard tentava, sob o nome de 'determinismo', reduzir todos os fenômenos vivos, psíquicos ou fisiológicos a formas especiais mais complexas dos atos físico-químicos”, por suas vezes,

Darwin, Huxley, Haeckel, Broca e principalmente Spencer formulavam uma nova doutrina para a matéria viva, a da 'evolução'; e depois de Lamarck, Comte, Malthus e outros precursores inconscientes, tentavam aplicar aos fenômenos sociais esta lei biológica, com seus fatores cegos de adaptação e seleção. ${ }^{461}$

Com essa argumentação, Louis Couty visava demonstrar que para essas doutrinas a individualidade desaparecia e que "por conseguinte, o homem tem apenas que se deixar arrastar no meio do conjunto das forças materiais que ele constata e admira sem poder modificar”. Em decorrência disso: "O poder do homem é nulo". Disso resultava que "as descobertas científicas que pensa ter realizado, os progressos higiênicos e morais por que luta são resultantes em que o esforço pessoal poderia ser negligenciado". Desse modo, Couty afirmava que "materialismo, espiritualismo, evolução, revolução são nomes que devem desaparecer se se quiser legar ao homem seu verdadeiro papel de individualidade pensante e agente [...]". Posto que, "a liberdade humana não é um direito ou um principio; é um fato, variável e contingente, como a combinação dos sais ou a germinação de um grão”.

Contudo, esse fato, segundo Couty, "apresenta uma modalidade especial" que separa "completamente

461 Idem, p. 238. 
os fenômenos materiais, psicológicos e sociais, dos fenômenos materiais biológicos ou físico-químicos”. Isto é: a "individualidade pensante ativa e livre é capaz de intervir nas mudanças que a cercam”. Com efeito, todos

os fatos demonstram que o homem reagiu no espaço e no tempo contra os fenômenos exteriores físico-químicos ou biológicos. Em vez de adaptar, ele aos poucos criou habitações, vestimentas, métodos de aclimatação, de domesticação, meios de defesa e de transporte, equipamentos diversos que se sofisticam cada dia mais. ${ }^{462}$

É interessante notar que, com essas análises sobre o indivíduo, Couty estava corroborando o discurso racialista/determinista de que em grupo ou isoladamente o negro seria inferior. Justificava que o negro era inferior, não só racialmente, mas como indivíduo. Por não ser o negro um indivíduo útil e ativo ele precisava ser rechaçado do processo civilizador por qual deveria passar o país. Louis Couty indicou essa análise em 1881 com a publicação do livro A escravidão no Brasil quando asseverava que: "O fato importante e capital vai nos ser fornecido pelo estudo dos costumes e das características sociais, e não pelo estudo das raças e dos caracteres étnicos”. Isto porque, segundo ele: "No Brasil, o liberto entra plenamente em uma sociedade na qual ele é imediatamente tratado como igual, ao passo que nas Antilhas e, especialmente na América do Norte, ele continua a ser, geralmente, um pária”. Desse modo, o escravo disporia "de meios para

${ }^{462}$ Idem, p. 238-240. 
sair, por si só, de sua condição", ${ }^{463}$ mas não saía porque segundo Couty "o negro no Brasil só pede uma facilidade, um direito: o de não fazer nada" ${ }^{464}$ Os fins eram os mesmos, mudavam-se os meios da justificativa. Isto é, para Couty, em uma sociedade que oferecia plenas condições de evolução, só não evoluíam aqueles que eram biologicamente e sociologicamente incapazes de por si chegar ao nível de civilizado.

A questão do povo na história do Brasil sempre esteve associada aos temas da mestiçagem e da escravidão. Esta preocupação percorre a história do país desde a colônia, mas foi a partir do século XIX que o tema ganhou mais relevância. A questão do povo é tão instigante que foi classificada por Francisco Weffort como "tema primordial da história das ideias no Brasil". 465

A análise de Louis Couty sobre o povo foi partilhada em sua época por Sílvio Romero, mais tarde Romero retomaria a questão da ausência de povo quando da recepção a Euclides da Cunha na Academia Brasileira de Letras em 1906. ${ }^{466}$

Ao mesmo tempo em que tinha suas ideias partilhadas pelos homens de seu tempo, Couty era veementemente criticado pelo movimento abolicionista. Quanto a

\footnotetext{
463 COUTY, Louis. A escravidão no Brasil, op. cit., 1988, p. 53.

464 Idem, p. 93. [grifo de Couty]

465 WEFFORT, Francisco C. Formação do Pensamento Politico Brasileiro: ideias e personagens. São Paulo: Ática. 2006, p. 328-329. Para um exame historiográfico da questão Cf. FALCON, Francisco. "O povo brasileiro: ensaio historiográfico”. In: Revista USP, São Paulo, n. 46, 2000, p. 30-41.

466 CARVAlHO, José Murilo. "Os três povos da República”. In: Revista USP, São Paulo, n. 59, 2003, p. 96-115.
} 
isso, a Gazeta da Tarde publicava em 1881 um artigo em que contestava os argumentos de Couty sobre sua ideia de considerar a escravidão como útil para o Brasil, mas que a liberdade do negro seria prejudicial à nação. Com efeito, lançava uma questão: "Por que motivo o Sr. Couty não formula de um modo mais categórico a demonstração da incapacidade do negro? Por que apenas atira certos postulados contra os quais protestam os fatos?". ${ }^{467}$ Todavia, Louis Couty seguia em sua convicção sobre a ausência de povo no Brasil. Em 1884 era sua vez de citar Sílvio Romero e acrescia o abolicionista Joaquim Nabuco no debate. A mestiçagem era a questão:

Seus defensores, aqueles que, com Sílvio Romero, julgam o mestiço superior ao branco, ou seus contendores, aqueles que, com Joaquim Nabuco, lamentam o fato de o país ter sido colonizado pelos portugueses e pelos negros, chegam à mesma conclusão: o Brasil não tem povo, ou melhor, o povo que the foi dado pelas misturas de raças e pelas alforrias não desempenha um papel ativo e útil. ${ }^{468}$

Na década de 1880 as discussões sobre o problema da mão de obra, sobre os destinos do país, mobilizavam um intenso debate que o próprio Couty colocava a necessidade de ser no futuro estudado. Nesse debate, como discussão, o povo era ativo. Com suas formulações sobre o povo, ou sua ausência, Couty sedimentava aspectos do cientificismo na imagem do Brasil como possuidor de

467 Gazeta da Tarde, 18 jul. 1881.

468 COUTY, Louis. "Imigrantes e libertos". (7 - 11 maio 1884). In: O Brasil em 1884, op. cit., 1984, p. 200. 
uma população atrasada - que precisava ser melhorada pela ação da imigração do branco -, de um povo improvável de ser representante do ideal de civilização que as elites buscavam. Sílvio Romero confirmava o diagnóstico de Couty ao aceitar que "que pouco, bem pouco, temos feito como nação culta”. ${ }^{469}$

Somando todos os caracteres raciais do negro, do índio e do mestiço, tal equação não teria como resultante um povo como o povo europeu, daí a alternativa imigrantista era a solução na mente de Couty e dos seus. Solução que não deveria se alongar no tempo, sendo urgente a necessidade de medidas que resolvessem a equação inconclusa do povo brasileiro. Buscava-se um substituto ao trabalho escravo, não apenas ao trabalho, mas ao indivíduo negro também. Queria-se um indivíduo regrado no trabalho e, bem por isso, a obra do português colonizador, implementador da escravidão, precisava ser rechaçada, a aventura do português devia ser substituída pelo trabalho organizado, profícuo, suficientemente capaz de pôr em prática a estruturação de um mercado interno e inserir o país numa ordem moderna de civilização. As teses de Couty iam ao encontro dos interesses das elites quanto ao tocante do branqueamento e modernização do país pela imigração europeia. Foi Couty um profícuo ideólogo do branqueamento, sedimentou imagens que, ao mesmo tempo, divulgava o Brasil como um paraíso, sem conflitos raciais e por outro lado demonizava a população existente ao insistir no discurso de que daquela camada da sociedade não poderia sair um povo.

469 ROMERO, Sílvio. "Introdução à história da literatura brasileira”, op. cit., 1881, p. 293. 


\subsection{Apreender ideias, revelar projetos}

Enfático em suas ações e pensamento, Louis Couty procurava incentivar reformas que facilitariam a vinda $\mathrm{e}$ a vida do imigrante. Foi contrário a qualquer ação que não tivesse a imigração europeia somada à introdução de máquinas na produção agrícola como alternativa. A solução para o futuro do país só seria possível pela imigração, do contrário disso dizia ele: "só existem o empirismo e a revolução armada, isto é, a derrocada total da importante produção do Brasil e das suas províncias mais florescentes". ${ }^{470}$

Contrário desde o princípio a uma abolição total, Couty estabelecia um projeto de ações que deveriam acontecer para que se estabelecesse uma corrente contínua de imigrantes europeus. Esse projeto imigrantista de Louis Couty encontra-se de modo mais prático e amplo no livro O Brasil em 1884. Prático porque estruturava os meios pelos quais deveria ser realizada a imigração, além de citar exemplos estabelecidos. Amplo porque se inseria numa corrente de ideias imigrantistas que ganhava mais força a partir da década de 1880 .

O livro O Brasil em 1884 é resultado de uma reunião de artigos que Louis Couty publicou na imprensa francesa da Corte entre os anos de 1883 a 1884, num total de quarenta e quatro. Todos os artigos reunidos foram publicados na folha Le Messager du Brésil. O livro foi publicado originalmente em francês pelos editores Faro \& Lino.

${ }^{470}$ COUTY, Louis. "Introdução”. In: O Brasil em 1884, op. cit., 1984 , p. 18. Esta reflexão continha críticas ao movimento abolicionista com o qual travou longo debate sobre os destinos do negro e do Império. 
Louis Couty tornou-se diretor do Le Messager du Brésill $^{471}$ além de criar outro periódico de publicação bimestral, Revue de France et du Brésil. Tinha projetos para a colônia francesa da Corte, como relatou o professor Gorceix num necrológio, Couty pensava em organizar uma escola francesa, "com professores que houvessem todos pertencidos à Universidade e que serviria de modelo para o ensino secundário no país". ${ }^{472}$ Pensou o país além do ponto de vista de um viajante. Estava estabelecido e pensava a partir desse ponto. Muito disso estava em seus debates, quando seus opositores questionavam suas ideias estrangeiras, ele replicava baseado em seus interesses de estabelecer vida no país.

Existe melhor prova de nossa confiança no futuro do Brasil do que o fato de que, na medida de nossas forças, procuramos ajudar a prepará-lo? Se acreditássemos, como alguns, no naufrágio do navio, será que perderíamos nosso tempo discutindo sobre os meios de reconduzi-lo ao rumo mais seguro, mais amplo e mais fácil? Temos a mais absoluta confiança no futuro do Brasil e só temos dúvidas quanto aos meios pelos quais esse futuro será alcançado. Será que esses meios serão pacificos? Desejamos intensamente que assim seja $e$ achamos isso possivel, se soubermos tomar imediatamente as medidas de povoamento e de transformação necessárias. ${ }^{473}$

471 Le Messager du Brésil tinha sede de sua redação e administração na Corte, Rua Sete de Setembro, número 131. Era publicado duas vezes na semana. Após a morte de Couty a folha deixou de existir.

472 "Biografia: L. Couty julgado pelo professor Gorceix". Gazeta Médica da Bahia, série 3, v. 2, p. 413, 1884-1885.

${ }^{473}$ COUTY, Louis. "As culturas do Brasil e seu rendimento" (10 a 13 abr. 1884). In: O Brasil em 1884, 1984, p. 101. [grifo nosso]. 
O seu interesse no Brasil encontra-se também em várias de suas decisões. Quando convidado a voltar para a França, não aceitou o convite e permaneceu com suas funções no Império. Essa era sua missão de homem de ciência, agente da civilização. De fato, Louis Couty também pensou a imigração de um ponto de vista pessoal. Não deixava de ser ele um imigrante em terras desconhecidas. Contudo, era um imigrante que ocupava funções destacadas e fundamentais no governo imperial. Foi bem recebido pela sociedade e assim queria que essa boa recepção se espraiasse para com os demais compatriotas franceses ou compatriotas de continente.

No livro O Brasil em 1884, vamos notar as ações e ideias de Louis Couty com uma dinâmica interessante. Todos os temas que Couty abordou nesses artigos estão inseridos no contexto do problema da mão de obra: escravidão, trabalho do nacional livre, imigração, colonização, ferrovias, café, hipotecas, pequena e grande propriedade, e a constituição do povo sombreando as discussões. Além disso, tocou em questões que se interligavam a demanda pelas reformas que, ao chegar os imigrantes, era preciso que fossem realizadas: secularização dos cemitérios, grande naturalização, casamento civil para o imigrante, medidas contra o estrangeirismo - que era, em seu entendimento, o preconceito contra imigrantes. Todas essas questões analisadas por Couty saíram em forma de artigo na imprensa francesa da Corte. Eram publicados a cada semana ou com maior espaçamento no período de dois anos, entre 1883 a 1884 . Esse é o primeiro aspecto da intervenção das ideias de Couty. Outro aspecto se relaciona a recepção e apropriação e mobilização de suas ideias no contexto em que elas foram elaboradas. 
Entre os anos de 1883 e 1884, Louis Couty atuou na redação do Le Messager du Brésil. Ali estavam materializadas as possibilidades de agir em prol de uma imigração útil para o Império. Seus textos, nesse período, ambientam a construção mais clara de suas ideias imigrantistas e de um projeto de colonização para o Império do Brasil.

Até 1883, Louis Couty escreveu/publicou relatórios, proferiu palestras públicas, ministrou cursos, publicou livros, realizou várias missões científicas e de comércio no Império e fora dele. Foi a partir de 1883, ano que publicou seu relatório sobre o café, que Couty começou a escrever seus artigos e divulgar amiúde suas ideias de um lugar de conforto, da colônia francesa da Corte, da sede do Messager du Brésil. Somados a este lugar francês, havia os outros estabelecimentos de Couty já tratados aqui, a Escola Politécnica, o Museu Nacional, que garantiam a ele a autoridade científica no assunto. Além disso, apresentou a definição mais bem acabada do modo pelo qual desenvolveu a chave interpretativa de análise da sociedade brasileira, o método pelo qual operou os problemas que no caminho encontrou, isto é, a Biologia Industrial. Louis Couty trouxe a público, de forma mais precisa, a definição de Biologia Industrial em 1883 com o relatório Étude de biologie industrielle sur le café. Desde então seus artigos no Le Messager du Brésil vão conter a marca de sua interpretação singular sobre o Brasil. Desse modo, da análise desses artigos somados aos outros livros revela-se o que denominamos de projeto imigrantista de Louis Couty.

Os problemas sociais hoje existentes no Brasil estão de tal forma interligados que devem ser resolvidos reciprocamente se não quisermos anular o 
passado, perder o que já possuímos e recomeçar $a b$ ovo a utilização das províncias mais importantes do país. Entretanto, é fácil classificar as reformas mais urgentes sob três títulos diferentes: imigração, isto é, substituição dos escravos por trabalhadores mais ativos e mais econômicos; medidas para a utilização dos antigos habitantes, caboclos ou libertos; medidas gerais para a tecnologia e para o câmbio. ${ }^{474}$

Louis Couty priorizou em seu projeto as reformas a partir de três pontos: imigração; medidas para a utilização do homem livre nacional e o incremento tecnológico no aparato agrícola somado às questões cambiais. Contudo, é a imigração e a substituição dos escravos a prioridade como demonstramos até aqui. De uma forma interessante, Couty estruturava suas ideias no texto diagnosticando o problema e mostrando a solução, em síntese, o problema era o trabalho escravo e a solução a imigração europeia. Contudo, apesar de não ver uso no trabalho do liberto que se somaria ao trabalho do nacional livre, colocava como possibilidade a utilização do trabalhador nacional. O uso do trabalhador nacional livre seria à guisa das orientações de Spencer, isto é, ocupando funções secundarias no processo de produção nacional.

[...] o negro e o mestiço têm muita aptidão para desempenhar certas funções sociais, como, por exemplo, aquelas que Spencer tão bem resumiu sob a designação de funções de distribuição ou de relação, mas continuam ineptos para as mais

474 COUTY, Louis. "As medidas necessárias”. (15 abr. 1884). In: O Brasil em 1884, op. cit., 1984, p. 231. 
importantes, as funções de produção, que requerem um trabalho continuado e regular. ${ }^{475}$

Um dos aspectos que utilizou para justificar funções secundárias do negro na divisão do trabalho se orientou na concepção determinista, sendo esse modo tão importante para Couty em suas definições que, segundo ele, "não existem nações onde a divisão do trabalho não tenha sido o produto de diferenças biológicas". 476 $\mathrm{Na}$ análise de Couty, portanto, tanto o negro liberto quanto nacional livre, sendo que ao ser liberto o negro tornar-se-ia membro da grande massa de homens livres, seriam inseridos na estrutura produtiva da sociedade em funções secundárias. O protagonismo produtivo caberia ao trabalho imigrante, que viria trazer todas as inovações tecnológicas necessárias para suplantar a enxada do negro e seu inferior trabalho. Para que o Império tornasse atrativo ao imigrante era preciso uma série de reformas que facilitariam a vinda e a permanência desse colono.

Nesse projeto de imigração que Couty desenvolveu, era preciso oferecer aos imigrantes as terras cultivadas, pois nelas o imigrante iria produzir mais que o negro escravizado. Após certo tempo a trabalhar e a melhorar de vida no Brasil o imigrante "escreverá então a todos os parentes e amigos dizendo que no Brasil se pode economizar depressa porque as culturas são fáceis e lucrativas". Com isso, o fluxo de "imigração espontânea se criará por si próprio, sem despesas nem lutas; e esse fluxo produzirá logo uma mão de obra capaz de assegurar [a]

475 COUTY, Louis. A escravidão no Brasil, op. cit., 1988, p. 103.

476 Idem, p. 104. 
manutenção das explorações atuais e aumentá-las mais tarde". ${ }^{47}$ Do contrário, se os imigrantes chegarem ao Brasil e forem enviados às terras virgens "voltará desencorajado; ou, se lá ficar, gastará muito e será pouco útil”. Era preciso, portanto, que a imigração tivesse uma direção, a das terras cultivadas. Resulta dessas constatações seu projeto imigrantista para o país.

Uma forma de colonização da terra cultivada proposto por Couty consistia no "cultivo das terras marginais às estradas de ferro, na compra dessas terras, na sua divisão em pequenos lotes destinando-se cada um a uma família de imigrantes. [...]”. Nesse argumento revela um traço interessante de seu projeto imigrantista, dizia ele que aplaudia a fundação da Sociedade Central de Imigração, mas que desejava "resguardar a nossa liberdade de ação e, certos de que os iniciadores dessa obra não suspeitam de nós, aproveitamos a oportunidade para discutir com eles um meio de colonização pelo qual parecem ter muito apreço" ${ }^{478}$ O meio era a colonização marginal às estradas de ferro. É interessante notar que Couty sentia necessidade de autonomia reflexiva em relação às questões imigrantistas e de colonização. Antes de ter suas ideias atreladas à organização da Sociedade Central, Couty reivindicava uma autonomia, resguardando suas ideias ao seu projeto, que poderia ulteriormente ser apropriado pelas organizações imigrantistas.

477 COUTY, Louis. "As culturas do Brasil e seu rendimento". (10 a 13 abr. 1884). In: O Brasil em 1884, op. cit., 1984, p. 107.

478 COUTY, Louis. "A colonização da terra cultivada: suas condições atuais”. (30 dez. 1883). In: O Brasil em 1884, op. cit., 1984, p. 109. [grifo nosso]. 
Em relação à forma de colonização das terras cultivadas, informava os exemplos bem-sucedidos dos Estados Unidos e procurava referendar seus argumentos citando uma revista francesa de inspiração econômica: "Ainda hoje, na Flórida, no Dakota e no Colorado instalam-se colonos nessas condições, e podemos encontrar informações sobre o assunto em diversos números recentes do Economiste français". Além dos Estados Unidos, outros lugares esse sistema de colonização havia sido empregado, caso da Argentina. Com efeito, reconhecia que esse sistema poderia "prestar serviços ao Brasil". ${ }^{479}$

No Congresso Agrícola do Rio de Janeiro em 1878, o marechal Henrique de Beaurepaire Rohan discutiu essa forma de colonização às margens das linhas férreas citando o que dizia o fazendeiro José Vergueiro.

O Sr. Vergueiro aconselha que ao longo das vias férreas e em terrenos férteis se estabeleçam, quanto antes, núcleos para a colonização ou emigração, e está convencido de que os particulares irão aos poucos, e segundo seus recursos, adotando a medida, que deve ser o zelo posto em prática pelo Governo Imperial. Esses núcleos terão por base: arrendamento e venda. Aconselha mais que no centro desses estabelecimentos se formem pequenas povoações, onde, à guisa do que se observa no Norte da Europa, encontre o colono o vizinho, o amigo, os recursos da vida [...]. ${ }^{480}$

\footnotetext{
479 Idem, p. 109.

480 ROHAN, Henrique de Beaurepaire. "O futuro da grande lavoura e da grande propriedade no Brasil. Memória apresentada ao Ministério da Agricultura, Comércio e Obras Públicas. In: Anais do Congresso Agrícola do Rio de Janeiro, 1878. Introdução e notas de José Murilo de Carvalho. Fundação Casa de Rui Barbosa. Edição fac-similar, 1988, p. 245.
} 
Interessante contrastar o que disse Rohan e Vergueiro com Couty, posto que Couty veio reforçar tal iniciativa e sua necessidade para atração de imigrantes. Nesse cenário da expansão férrea, Couty notava que em 1883 o Império havia realizado, em quinze anos, "consideráveis progressos em sua tecnologia nacional; construiu quase mil quilômetros de estradas de ferro", que durante o mesmo período outras obras foram realizadas, porém a imigração era "insuficiente em relação às necessidades". Para Couty toda a tecnologia empregada deveria servir ao imigrante, descartando assim os outros trabalhadores. Para tanto, citava um discurso de Alfredo d'E. Taunay: "Esse país constrói estradas de ferro, mas não quer imigração", e reforçava a necessidade da imigração. ${ }^{481}$

No projeto de Couty, o imigrante deveria ocupar as melhores terras, as já cultivadas, estar próximo das vias de transportes e receber pequenos lotes para produzir. Ao liberto, ao caboclo, isso não caberia, posto que, segundo a lógica de Couty, esses trabalhadores eram ineptos e possuíam a marca da irregularidade no trabalho, não produziam como produzia um colono europeu.

Nesse seu projeto de imigração, de civilização para o Brasil, a uma classe cabia lugar de destaque, a classe dos fazendeiros a "mais ativa e mais inteligente que as outras". Posto que, foram os fazendeiros que "fizeram a força e a riqueza nacionais”. Interessante que Couty anula a participação do trabalho do africano escravizado ao dizer que os fazendeiros "abriram e desbravaram as matas

481 COUTY, Louis. “Tecnologia e povoamento”. (9 ago. 1883). In: O Brasil em 1884, op. cit., 1984, p. 26. 
virgens, instalaram as grandes culturas de açúcar e de café; foram eles que construíram as estradas, as usinas e as estradas de ferro importantes". Ao anular a ação de trabalho dos trabalhadores escravizados nesse processo de construção do Brasil, Couty exalta a individualidade empreendedora daquele que, para ele, pode salvar o Brasil da crise que poderia levar o país à ruína se não organizar o processo de substituição do trabalho escravo pelo trabalho livre. ${ }^{482}$

Essa classe de fazendeiros não é fechada como as antigas aristocracias francesa ou russa. Muito diferentes dos lordes ingleses, com os quais são comparados sem nenhuma razão, os fazendeiros não estão protegidos por nenhuma lei especial de impostos ou de herança. Se eles representam uma aristocracia, esta aristocracia está fundamentada em seus próprios esforços. [...]. ${ }^{483}$

Couty insere os fazendeiros numa ordem moderna de sociedade, são eles empreendedores, na medida em que eles incentivam tudo aquilo que Couty listou. Foi pelo esforço e não pela herança consanguínea que eles fizeram a riqueza queria dizer Couty. Por isso, por esse esforço seriam eles os mais capazes de conduzir o processo de substituição do trabalho escravo pelo trabalho livre. Quando Couty tecia elogios aos fazendeiros, estava ele elogiando um grupo de fazendeiros que Couty chamou de fazendeiros do futuro, que em sua maioria se localizavam

482 COUTY, Louis. "A Lei de São Paulo e a Colonização da Terra Cultivada”. (20-27-30 mar. 1884). In: O Brasil em 1884, op. cit., 1984, p. 216. 483 Idem, p. 216. [grifo nosso]. 
na província de São Paulo. Por isso, se colocava contra aqueles que transformavam "esta classe num verdadeiro bode expiatório, que explicaria todas as dificuldades apenas por sua simples presença”. ${ }^{484}$ Nesse caso, Couty analisa a crise do Brasil por uma origem a mão de obra escrava do negro africano que veio pela ação do colonizador português. Para Couty, esta era a origem do problema do Brasil e não os grandes proprietários.

Em "um certo número de fazendeiros", os do passado, Couty observa os obstáculos para a divisão da grande propriedade em lotes para pequenos proprietários. É a possibilidade da divisão, da transformação de imigrantes em pequenos proprietários, que vai atrair uma corrente de imigrantes para o país. Por isso, era necessário convencer os fazendeiros do passado:

De que não se trata de acabar com as fazendas nem de transformar todos os colonos em pequenos proprietários. Deseja-se simplesmente converter aos poucos as fazendas em grandes vilarejos; e como nos Estados Unidos e na República Argentina, deseja-se criar progressivamente uma mistura de grandes proprietários, de meeiros, de arrendatários, de assalariados, numa palavra, de homens livres de todas as classes. ${ }^{485}$

Outras medidas deveriam ser tomadas para que o colono imigrante se sentisse confortável para vir ao Brasil e permanecer no país. Essas medidas que Louis Couty abordou em seus artigos e livros se relacionam às

${ }^{484}$ Idem, p. 217.

485 Idem, p. 222. [grifo nosso]. 
reformas de modernização que tomaram conta do Império em sua década final. A questão era simples para o cientista, para realizar a colonização era "preciso fazer reformas sociais absolutamente indispensáveis na esfera do povoamento e da propriedade". ${ }^{866}$ Sem tais reformas a colonização não se daria em pleno êxito.

$\mathrm{Na}$ perspectiva de Louis Couty algumas questões precisavam ser resolvidas para que a corrente imigratória se fizesse e se cumprisse em pleno êxito. O "estrangeirismo" era um comportamento que precisava ser rechaçado. Segundo Couty, o estrangeirismo era uma forma de se relacionar própria de Portugal, mas que havia eivado o jeito de ser do brasileiro. Estrangeirismo era a desconfiança do estrangeiro, mas do estrangeiro que não é português. Esse estrangeirismo constitui o que Couty chamou de "caráter social perfeitamente definido". Esse caráter próprio do brasileiro, mas herdado de Portugal explicava:

A ausência de naturalização, a religião do Estado com o estado civil nas mãos dos padres, uma lei de contratos como a de 1879 , o pouco sucesso das tentativas de colonização e, sobretudo, é ela [a desconfiança própria do estrangeirismo] que explica os fatos tão nocivos que se reproduzem todos os dias. [sic]. ${ }^{487}$

Os fatos nocivos do cotidiano eram, por exemplo, "a interdição de produtos farmacêuticos franceses" que, por sua vez, eram "vendidos no mundo inteiro". Essa

486 COUTY, Louis. "As culturas do Brasil e seu rendimento". (10 a 13 abr. 1884). In: O Brasil em 1884, op. cit., 1984, p. 108.

487 COUTY, Louis. "O estrangeirismo”. (20 dez. 1883). In: O Brasil em 1884, op. cit., 1984, p. 99. 
aversão em firmar contrato sem necessariamente conhecer o outro, prevalecendo a desconfiança ao invés da fiança gerava infortúnios ao povo brasileiro como a "Questão Tripoti”, ou seja, o impedimento por parte do governo italiano da saída de colonos, "cada dia mais necessários", para o Brasil. ${ }^{488} \mathrm{O}$ estrangeirismo era um problema que fomentava outros problemas que, por sua vez, deveriam ser levados em consideração na medida em que atrapalhava a vinda do imigrante tão desejado.

Diante disso, uma série de reformas seria necessária. A regulamentação do casamento civil era uma das medidas a serem executadas em prol de reformas. ${ }^{489}$ Além dessa questão do casamento civil, outras ações deveriam acontecer.

A grande naturalização, a igualdade de religiões e o registro civil são as primeiras condições do progresso social. Estamos convictos de que essas reformas, já aceitas pela maioria dos brasileiros cultos, já propostas às Câmaras por homens como Taunay, Silveira Martins, Saldanha Marinho, L. de Carvalho e Maciel, farão logo parte das leis do País; e a última lei eleitoral, votada graças aos esforços do Sr. Saraiva, já realizou grande progresso nesse sentido. Mas um outro obstáculo poderoso ainda permanecerá no âmbito dos costumes e é preciso lutar contra ele para fazê-lo desaparecer. ${ }^{490}$

488 Idem, p. 100.

489 COUTY, Louis. "O casamento civil”. (11 abr. 1884). In: O Brasil em 1884, op. cit., 1984, p. 229. Para Louis Couty a regulamentação do casamento civil seria um grande avanço para o Brasil e daria autonomia de ação aos individuos, op. cit., p. 229.

490 COUTY, Louis. "Nacionais e estrangeiros". (4 maio. 1884). In: O Brasil em 1884, op. cit., 1984, p. 193. 
É interessante contextualizar o trecho acima, pois ele vem em decorrência de um longo debate sobre os destinos dos negros e do Império que Couty travou com o movimento abolicionista, especialmente o ligado à Gazeta da Tarde. Couty é afirmativo em considerar os ataques da Gazeta da Tarde como sendo atos de estrangeirismo, por isso ele lutava contra esse "vicio social" e em favor dos imigrantes que "trouxeram para o Brasil mais ou menos todas as suas indústrias, suas artes, suas culturas. Os franceses ensinaram, em quase toda parte, a arte do fabrico do pão, do sapato, das vestimentas, a arte dos restaurantes, das modas [...]". ${ }^{491}$ Listou uma série de feitos que atribuiu aos imigrantes franceses. Nessas afirmativas de Louis Couty notamos os meios pelos quais ele delineou um projeto de imigração e de defesa dos interesses dos imigrantes a fim de que estes fossem assimilados como cidadãos de fato num país onde seriam estrangeiros. Por isso, essas medidas de facilitar a naturalização, o casamento civil, a secularização dos cemitérios - o problema da religião de Estado -, facilitar a compra de pequenas propriedades e a sua luta contra o vício do estrangeirismo, estavam inseridas no âmbito de um projeto pessoal. Sua ação a partir de 1883 se deu nesse aspecto, de facilitar ao máximo a vinda e a permanência dos imigrantes.

Nesse projeto imigrantista de Couty é interessante notar a evolução da ideia da atuação do Estado na condução da imigração.

Enfim, o Estado intervém diretamente para orientar os novos habitantes e mais tarde obrigá-los a

491 Idem, p. 192. 
se tornarem cidadãos. Nesse sentido oferece-lhes, em condições de fácil pagamento, grandes faixas de terra própria para a cultura ou para a criação de animais, com possibilidade de lucro imediato. ${ }^{492}$

No trecho acima Couty mostra como foi a ação do Estado nos Estados Unidos, com a criação de estabelecimentos para a recepção dos imigrantes. Nesse caso, ele objetiva uma ação direta do Estado. Poucos meses depois ele vai renunciar essa ideia de maior intervenção do Estado. Dizia que "ninguém defende mais a colonização pelo Estado", sobretudo porque "nenhum país tentou sob essa forma de condições”, ao se referir às colônias do Estado. O governo não deve promover o povoamento, "deve apenas facilitá-lo”. Posto que, "sua intervenção direta custa muito caro”. E dizia: "Já renunciamos a ela; é de se esperar que não voltemos atrás". ${ }^{493}$

De fato, Couty não voltou atrás nessa concepção de ação do Estado na condução da imigração para o Império. Ele vai definir melhor essa ideia ao notar que "o Estado deve intervir. Não poderá ficar sempre na expectativa [...]”. Contudo, coloca-se de modo contrário a uma ação direta e exclusiva do Estado nos modos de arregimentar a mão de obra para o Império. Ao Estado caberia, "através de uma série de medidas”, ser um agente que visasse "facilitar a ação dos particulares, em especial dos grandes proprietários, que precisam de mão de obra e não podem

492 COUTY, Louis. “A colonização e o governo”. (13 set. 1883). In: O Brasil em 1884, op. cit., 1984, p. 24.

493 COUTY, Louis. “Exploração e colonização”. (4 a 11 nov. 1883). In: O Brasil em 1884, op. cit., 1984, p. 86. 
diretamente obtê-la". ${ }^{494}$ Deve-se a sociedade agir em conjunto, o Governo e as organizações civis para realizar as reformas necessárias e garantir o futuro do Império.

Em vez de substituir diretamente lotes de terras virgens e pequenas casas, como fez até agora, o que custa caro e não resolve a crise de trabalho escravo nem satisfaz os imigrantes, o Estado deve simplesmente facilitar a instalação de empresas ou sociedades que começarão a divisão das fazendas endividadas entre os colonos já bem de vida e que mais tarde farão o povoamento das terras devolutas, como fizeram nos Estados Unidos e na Austrália. ${ }^{495}$

O Estado na concepção de Couty deveria agir de forma a facilitar a ação dos indivíduos organizados em empresas ou sociedades, a fim de que estas agissem. Seus elogios à fundação da Sociedade Central de Imigração se relacionam a esta forma de entender a função do Estado. Anunciando o aparecimento de várias associações no ano 1883, entre elas a da Liga do Ensino, Sociedade dos Letrados e etc., notava Couty que, com isso, "estas repetidas eclosões, sem união aparente, demonstram a importância que tomou nesse país uma força até então rudimentar, a iniciativa associada". Isso era a demonstração de que "os indivíduos já deixaram de esperar o que quer que seja desta divindade vaga, mutável e muitas

${ }^{494}$ COUTY, Louis. "A colonização da terra cultivada: suas condições atuais”. (30 dez. 1883). In: O Brasil em 1884, op. cit., 1984, p. 112.

495 COUTY, Louis. "As medidas necessárias". (15 mar. 1884). In: O Brasil em 1884, op. cit., 1984, p. 232-233. 
vezes parcial chamada Estado". ${ }^{496}$ Era o Brasil mais ativo que tanto queria Couty. Esse movimento interno de associativismo seria útil na vulgarização dos produtos do Império com a ação do Centro da Lavoura e na atração de imigrantes com a Sociedade Central.

Louis Couty, homem de ciência, mas também de comércio, publicista, amigo do Brasil, protagonista no debate sobre os destinos da mão de obra e do Brasil, trilhou um percurso que no tempo foi curto, mas amplo no significado e nas ações. Seu projeto imigrantista para o Brasil poder ser compreendido, na medida em que deslindamos seu percurso, analisamos seus textos, apreendemos o modo pelo qual ele interpretou o Brasil e forjou esse amplo projeto imigrantista.

$\mathrm{Na}$ "estupenda relação de trabalhos científicos e sociológicos", como se referiu Alfredo d'E. Taunay ${ }^{497}$ aos trabalhos de Couty, notamos, após analisá-los num conjunto estruturado, que o projeto imigrantista de Louis Couty partia de um ponto de vista pessoal, pois tinha como lugar de ação o impresso Le Messager du Brésil. Contudo, não foi a partir de sua ação no Le Messager du Brésil que passou a acreditar na imigração como meio de alçar o Império no caminho do progresso e da civilização, mas foi no Le Messager du Brésil que empregou todo seu conhecimento, após suas missões e diagnósticos, sobre o Império e direcionou suas críticas e sugestões de como deveria ser realizada a imigração. Sua atuação como

496 COUTY, Louis. "O Brasil no exterior e o Centro da Lavoura e Comércio”. (25 maio 1884). In: O Brasil em 1884, op. cit., 1984, p. 250. 497 TAUNAY, Alfredo d'E. Estrangeiros ilustres e prestimosos no Brasil (1800-1892), op. cit., 1932, p. 43-60. 
publicista, e ele se colocava como um publicista, tornou-se o meio pelo qual suas ideias agiram no contexto dos debates sobre a mão de obra na década final do Império do Brasil. Com efeito, o projeto de Louis Couty se organizava em decorrência de suas observações na produção cafeeira das províncias do Rio de Janeiro e São Paulo. Em decorrência dessas observações pelas regiões cafeeiras, vai criticar o trabalho do escravo ao considerá-lo pouco produtivo, vai descartar o trabalhador nacional livre ao considerá-lo como incapaz de manter regularidade no trabalho; e, ao atribuir as melhores características ao trabalho livre do imigrante europeu, vai propor como solução da crise que acometia a produção do café a vinda de imigrantes. Para que esses imigrantes viessem era preciso reformas e ações. É interessante notar que a condução desse processo caberia ao fazendeiro, o do futuro como dizia ele, que em conjunto com as medidas estabelecidas pela Lei do Ventre Livre, engataria o país no progresso rumo à civilização. Entendemos deste modo descrito o projeto de Louis Couty.

Revelamos os lugares, o percurso e a formação das ideias de Louis Couty sobre a sociedade brasileira de final dos Oitocentos, agora é importante demonstrar como tais ideias foram assimiladas pela Sociedade Central de Imigração, órgão que teve destacada atuação na organização da imigração para o Brasil no final do século XIX. 


\section{$\{5\}$}

\section{Apreender projetos, contrapor ideias: Louis Couty e a Sociedade Central de Imigração}

Como instalar a pequena propriedade no lugar da grande propriedade? Como substituir o escravo, absolutamente dependente, pelo colono livre, meeiro ou arrendatário, mas patrão de si mesmo? Aí justamente começam as verdadeiras dificuldades, as que não se resolverão por artigos de jornal, discursos ou leis, mas por tentativas múltiplas e, sobretudo, por observações sérias das quais algumas já são possíveis. ${ }^{498}$

O trecho acima é de janeiro de 1884 , poucos meses após a fundação da Sociedade Central de Imigração. Era um momento em que o debate público estava amplo, mas que de nada adiantaria debater mais se essas ideias que circulavam não fossem empregadas em ações. Nesse sentido, a Sociedade Central, entre outras organizações que Couty nutria admiração, teria papel importante de agir em favor de reformas que providenciassem a vinda e, sobretudo, permanência de imigrantes.

O prestígio de suas ideias reverberou, entre outros lugares, na Sociedade Central de Imigração. Essa apropriação

498 COUTY, Louis. "A colonização e o Estado". (3 jan. 1884). In: O Brasil em 1884, op. cit., 1984, p. 118. 
se realizava, muito embora Louis Couty não tenha se filiado à Sociedade Central de Imigração, como ele mesmo atesta em artigo.

Aplaudimos a fundação da Sociedade de Imigração; aprovamos a maioria dos pontos do seu programa; assinalamos todas as medidas úteis que tomou; insistimos no papel de propaganda e popularização que ela deveria representar. Entretanto não nos colocamos à sua completa disposição e, pessoalmente, dela não fizemos parte. ${ }^{499}$

No entanto, isso não o impediu de participar de reuniões e, especialmente, de ter suas ideias utilizadas pela Sociedade Central como propaganda de seus ideais e de seus projetos reformistas. A proximidade de Couty com os membros da referida Sociedade traz indícios de sua inserção em uma rede de sociabilidades que tem na família Taunay aspecto importante. As relações que Louis Couty estabeleceu na Corte, em seus lugares de ação, Escola Politécnica e Museu Nacional, deixaram-no próximo de Goffredo Taunay, com quem fez vários trabalhos e missões em parceria. Além disso, várias citações em seus textos referem-se a Alfredo d'E. Taunay, bem como nos encontros que teve com Alfredo Taunay, como na festa de inauguração da Máquina Taunay-Telles, que já

499 COUTY, Louis. "A colonização da terra cultivada: suas condições atuais”. (30 dez. 1883). In: O Brasil em 1884, op. cit., 1984. p. 109. A historiografia que tratou de alguns aspectos de Couty sempre o colocou como membro da Sociedade Central de Imigração. No entanto, não encontramos evidências concretas dessa associação à Sociedade Central. Diante disso, ficamos com a própria fala de Couty sobre seu não pertencimento à Sociedade Central. 
comentamos. Isto revela o seu livre trânsito com os membros da familia Taunay, sobretudo sua inserção na rede dessa família, que esteve estrategicamente ligada à criação de um campo de ação para os intelectuais brasileiros, balizado pela presença protetora do Estado Imperial. Essa rede de sociabilidade dos Taunay articulou a divulgação de uma cultura francesa e a articulação de uma visão europeia sobre Segundo Reinado. ${ }^{500}$ Essa inserção de Couty na rede da família Taunay, além de sua proximidade com outros membros da Sociedade Central, sobretudo o uso de suas ideias pela Sociedade Central, possibilitou seu livre trânsito no seio da elite intelectual e cultural do Império. Pela pena de Alfredo Taunay, a memória de Couty, suas ações e ideias, foram preservadas no que ficou sendo a primeira biografia de Couty. Isto é, o esboço biográfico colocado como introdução para edição póstuma de Couty que a Sociedade Central editou.

A Sociedade Central tinha entre suas propostas a ruptura com o monopólio da terra - a grande propriedade - a fim de transformá-la em pequena propriedade e atrair imigrantes. Nesse sentido, em algumas questões e debates com os quais se deparou a Sociedade Central, os argumentos de Couty foram assimilados num movimento de ação para contrapor ideias que eram contrárias às suas ações e projetos. Além disso, a Sociedade Central publicou um livro póstumo de Couty em 1887, inserindo o livro numa série de publicações de propaganda que

500 COSTA, Wilma Peres. "Narrativas de viagem no Brasil do século XIX: formação do Estado e trajetória intelectual”. In: Intelectuais e Estado. (Orgs.) RIDENTI, Marcelo; BASTOS, Elide Rugai; ROLLAND, Denis. Belo Horizonte: UFMG, 2006, p. 43-46. 
visavam atrair imigrantes e conscientizar os brasileiros para a necessidade da imigração.

Após a morte de Louis Couty em novembro de 1884, a Sociedade Central realizou, através de seus boletins, intensa campanha em prol de uma sepultura digna de quem tanto havia honrado o país. Na campanha realizada para arrecadar fundos para a construção e manutenção da sepultura de Couty, foi mobilizada uma rede de filiais da Sociedade Central ficando visivel que esta rede possuía extensa capilaridade de ações, abarcando uma parcela importante do território imperial. ${ }^{501}$ Nessa campanha, foi destacada a atuação de Alfredo d'E. Taunay, a fim de recolher verbas para o túmulo de Louis Couty.

\subsection{Projetos e ações da Sociedade Central}

As mudanças econômicas que ocorreram no final do século XIX, em particular a expansão da economia de exportação, criaram certas condições no Brasil que possibilitaram o crescimento de camadas sociais intermediarias compostas nem de trabalhadores manuais, nem de membros da elite latifundiária. ${ }^{502}$ Desse modo, as décadas de 1870 e 1880 foram marcadas por uma série de iniciativas de cunho reformista que de modo geral visavam à supressão das instituições atreladas ao regime escravista e a modernização do país por reformas

501 Boletim: A Immigração, ano 2, boletim n. 10, abr. 1885.

502 HALL, Michael M.. "Reformadores de classe média no Império brasileiro: A Sociedade Central de Imigração”. Revista de História, São Paulo, v. 53, n. 105, ano 27, 1976, p. 147. 
amparadas em algumas bases. Dentre essas bases estava a via imigrantista. De um ponto de vista imigrantista, a Sociedade Central de Imigração foi a organização social mais representativa. Contribuiu para a teorização idealizada do povo brasileiro ao buscar no imigrante ideal a solução para os destinos do país. Além disso, tornou-se uma espécie de gerenciadora das demais associações imigrantistas espalhadas pelo Império. ${ }^{503}$

No processo de organização da imigração para o Brasil, a Sociedade Central de Imigração pode ser caracterizada como um suporte dinâmico, "uma inspiradora lúcida e coordenadora eficaz" para o bom êxito do movimento imigratório e no empenho do aproveitamento das novas técnicas do progresso. ${ }^{504}$ Os objetivos gerais da Sociedade Central se desenvolveram em dois aspectos. No primeiro, a preocupação se dava em motivar a vinda dos imigrantes e preparar-lhe uma boa acolhida. Ulteriormente, fixar o imigrante ao solo, dando sentido à colonização. ${ }^{505}$

A fundação da Sociedade Central de Imigração ocorreu no Rio de Janeiro em 1883, seu tempo de ação perdurou até de $1891 .{ }^{506}$ As primeiras ideias de formação da Sociedade teriam surgido de conversas entre Carlos Von Koseritz, Hermann Blumenau e Hugo Gruber. Em 26

${ }^{503}$ Cf. VASSILIEFF, Irina. A Sociedade Central de Imigração nos fins do século XIX e a "Democracia Rural". São Paulo: Tese (Doutorado em História Social) - Departamento de História da FFLCH/USP, 1887. HALL, Michael M., op. cit., GONÇALVES, Paulo Cesar. Mercadores de braços, op. cit., 2012.

504 VASSILIEFF, Irina. A Sociedade Central de Imigração nos fins do século XIX e a "Democracia Rural”, op. cit., 1887, p. 25.

505 VASSILIEFF, Irina, op. cit., p. 39-40.

506 HALL, Michael M., op. cit., p. 148. Ver também: GONÇALVES, Paulo, op. cit., 2012, p. 171-172. 
de setembro de 1883 Carlos Von Koseritz e André Rebouças conversaram sobre a futura sociedade ${ }^{507} \mathrm{~A}$ partir desses movimentos e conversas já estavam acertadas as bases de fundação e atuação da Sociedade Central.

Em 17 de novembro de 1883 ocorria a primeira sessão da Sociedade Central de Imigração, que teve a honra da augusta presença do Imperador Pedro II que, consagrando a ideia patriótica de sua fundação, considerou o acontecimento um ato de utilidade pública. ${ }^{508} \mathrm{Em}$ 30 de dezembro de 1883, por sua vez, Couty aplaudia "a fundação da Sociedade [Central] de Imigração" e aprovava "a maioria dos pontos do seu programa". Reforçava o pensamento do "papel de propaganda e popularização" da imigração que a Sociedade Central deveria represen$\operatorname{tar}^{509}$ Meses mais tarde Couty anotava para uma característica importante do ano de 1883, ano que "viu nascer diversas sociedades" num movimento que demonstrava a força da "iniciativa associada". 510

Os líderes da Sociedade Central eram homens de certa importância e muitas das suas ideias gozavam de extrema popularidade. A análise da composição, da organização, das atividades, do programa da Sociedade

\footnotetext{
507 VASSILIEFF, Irina, op. cit., p. 28.

508 Idem, p. 35.

509 COUTY, Louis. "A colonização da terra cultivada: suas condições atuais”. (30 dez. 1883). In: O Brasil em 1884, op. cit., 1984, p. 109.

510 COUTY, Louis. "O Brasil no exterior e o Centro da Lavoura e Comércio”. (25 maio 1884). In: O Brasil em 1884, op. cit., 1984, p. 250. Além da fundação da Sociedade Central, foram observados por Couty a fundação da Liga do Ensino, a Sociedade dos Letrados, a Sociedade da Escola de Farmácia, a Sociedade da Infância Desamparada, além das sociedades emancipadoras que "já nem contamos mais” diante do numero crescente delas.
} 
Central auxilia no entendimento dos modos de como o liberalismo de classe foi operado dentro do contexto brasileiro dos últimos anos do século XIX. ${ }^{511}$ Sua direção coube a indivíduos de um novo seguimento social que se constituiu nos interstícios do esquema senhor versos escravo e teve como espaço privilegiado as cidades. Eram, sobretudo, intelectuais, profissionais públicos e negociantes envolvidos no comércio externo. Praticamente todos os líderes tinham filiação com a Europa, através de nascimento, família, educação ou negócios. Demonstraram ser uma nova força na vida brasileira: um grupo de classe média consciente de seus interesses próprios e donos de uma crítica coerente e cabal da sociedade tradicional brasileira..$^{512}$

O quadro social de membros da Sociedade Central pode ser caracterizado como sendo composto por uma elite intelectual, política e econômica. Não havia, por exemplo, libertos ou qualquer outro elemento nacional que fizesse parte dos sócios da Sociedade. Portanto, contava com um grupo de indivíduos que possuíam notória posição de destaque na sociedade imperial. Ocupavam seus membros cargos públicos de elevado escalão, eram representantes políticos no parlamento, profissionais liberais. ${ }^{513}$ Além de muitos serem membros de famílias com longa tradição na vida imperial, caso da família Taunay.

Analisando os membros da Sociedade Central de Imigração, Irina Vassilieff constatou que pelo menos um número apreciável defendia um "projeto modernizador" da

511 HALL, Michael M., op. cit., p. 148.

512 Idem, p. 153.

513 VASSILIEFF, Irina, op. cit., p. 9. 
sociedade brasileira. A "modernização" e a "reforma” como projeto só seria possível de apreensão quando vista em separado e no decorrer de diversas décadas. Nesse aspecto os membros da sociedade se integraram, além da defesa da imigração, às campanhas abolicionistas e republicanas. ${ }^{514}$

Seu projeto era abrangente, ia além da constituição de núcleos coloniais de imigrantes em pequena propriedade. Além disso, o projeto abrangia reformas institucionais, ampliação da cidadania com a inclusão de imigrantes como cidadãos de pleno direito. ${ }^{515}$ Portanto, havia um projeto amplo de reformas que ia além da necessidade de atrair braços para a lavoura. Nesse âmbito, a urgência da necessidade de braços fomentou a criação na província de São Paulo de uma sociedade - a Sociedade Promotora de Imigração - que se tornaria responsável pela introdução de imigrantes nesta província. ${ }^{516}$

As primeiras aproximações entre a Sociedade Central com grupos de agricultores e proponentes da vinda de imigrantes da província de São Paulo se deram em 1885 através do que ficou sendo chamado "Terceiro Manifesto" em que se comentavam as potencialidades de São Paulo para receber uma corrente espontânea de imigrantes. Nesse manifesto, a Sociedade Central evoca os nomes principais da agricultura paulista como Antonio Prado, Martinho Prado, Souza Queiroz, Vergueiro e etc. Estes agricultores estavam vinculados à Sociedade de

\footnotetext{
514 Idem, p. 3-4.

515 Idem, p. 4.

516 Cf. GONÇALVES, Paulo Cesar. Mercadores de Braço, 2012, p. 188-221.
} 
Imigração de São Paulo que era uma das várias filiais ligadas a Sociedade Central. ${ }^{517}$

Alguns políticos e fazendeiros paulistas que faziam parte da Sociedade de Imigração de São Paulo decidiram criar a Sociedade Promotora de Imigração. Sendo esta fundada em 30 de junho de 1886 sob a liderança de Marinho Prado, Antonio Queiroz Telles e Visconde de Parnaiba. ${ }^{518}$ Conhecidos como irmãos Prado, Antonio e Martinho participaram de duas Sociedades: Sociedade de Imigração de São Paulo e Sociedade Promotora de Imigração, sendo que Antonio Prado também foi sócio da Sociedade Central de Imigração. Tiveram eles papel importante no processo imigratório, tanto em São Paulo quanto em âmbito nacional. ${ }^{519}$

\subsection{As divergências entre a Sociedade Central de Imigração e a Sociedade Promotora de Imigração}

O centro das divergências entre a Sociedade Central e a Sociedade Promotora aparece, de forma clara, nos discursos de Alfredo Taunay, um dos principais líderes da Sociedade Central. Em um deles pronunciado no Senado em 10 de setembro de 1886, Taunay defendia o grande objetivo da Sociedade Central que era tornar os imigrantes pequenos proprietários. Enquanto que a posição da

517 VASSILIEFF, Irina, op. cit., p. 66-67. Além da Sociedade de Imigração de São Paulo, havia outras sociedades filiais, da Sociedade Central de Imigração, na província de São Paulo. Eram elas: a Sociedade de Imigração de Sorocaba, a Sociedade Taubateana de Imigração e Sociedade de Imigração de Santos (VASSILIEFF, op. cit., p. 65).

518 VASSILIEFF, Irina, op. cit., p. 79-80.

519 Idem, p. 76-77. 
Sociedade Promotora tinha como objetivo resolver as dificuldades dos fazendeiros paulistas atraindo mão de obra para as roças de café. Com isso, Taunay deixava de ter simpatia por São Paulo. Na política imigratória do Império a Sociedade Promotora firmou suas posições e diretrizes. Tornou-se o órgão de ação dos cafeicultores paulistas que conduziu a entrada de imigrantes impondo seus interesses no processo. ${ }^{520}$

\subsection{Louis Couty e Sociedade Central: os termos da apropriação}

A Sociedade Central de Imigração espraiou seu ideal Império afora, nomeou, em cada colônia, um delegado de confiança para transmitir as informações e receber informações do que se passava nas colônias de norte a sul. No âmbito externo, escolhiam comissões de pessoas ativas e bem colocadas na sociedade europeia, sendo brasileira ou mesmo europeia, a fim de darem informações amplas de caráter positivo sobre o Império e na imprensa responderem as acusações direcionadas ao Brasil. ${ }^{521}$ Desse modo, houve um ordenamento estratégico das ações da Sociedade Central na Europa que visou propagar a ideia do Império como um território habilitado a receber imigrantes, além de contrapor ideias que viessem macular a imagem do Império no estrangeiro. Nesse sentido, Louis Couty, reconhecido cientista, estudioso

520 VASSILIEFF, Irina, op. cit., p. 83-84. Cf. HALL, Michael. Reformadores de classe média no Império brasileiro. op. cit., 1976. GONÇALVES, Paulo Cesar. Mercadores de braços. op. cit., 2012, p. 171-172.

521 VASSILIEFF, Irina, op. cit., p. 42. 
das questões da transformação da mão de obra, notório defensor dos interesses do Império no estrangeiro, eminente publicista defensor da imigração europeia, seria uma referência conceitual importante para os interesses da Sociedade central. As ações e as ideias de Louis Couty agiram de forma ativa em seu contexto, dessa ação no debate público sobre a substituição do trabalho escravo pelo trabalho livre, apreendemos o projeto imigrantista de Couty e como se estabeleceu uma conexão com os interesses reformistas via imigração da Sociedade Central. A premissa do cientista era de que o negro escravizado tinha um trabalho inferior e que era necessário substituí-lo pelo trabalho do imigrante europeu, economicamente e socialmente superior. Essa inferioridade constatada pela ciência precisava ser comprovada e todo esforço era empreendido com esse escopo. Resultado desses esforços de Couty foram seus textos, relatórios e livros, suas ideias em movimento. A partir disso se estruturou uma conexão entre o projeto de Couty com as ações da Sociedade Central, inteligível na materialidade das fontes que decorreram dessas interações de uma referencia conceitual como Couty para uma organização de ação como a Sociedade Central.

\subsection{O holandês Van Delden Laerne no Império}

Em setembro de 1883 chegava à Corte, pelo paquete francês Orénoque, o holandês Van Delden, sendo sua presença amplamente divulga nos periódicos da Corte e da província de São Paulo. De acordo com a imprensa da época, Laerne possuía plantações de café na ilha de 
Java, possessão da Holanda à época. Além de cafeicultor em Java, o holandês ocupava "elevado cargo na administração das colônias holandesas". ${ }^{222}$ A ilha de Java foi um importante competidor do Império nos assuntos do café. De 1840 para frente, foi a única região produtora mundial que se mostrou capaz de competir com a produção cafeeira brasileira. Suas trajetórias foram bastante distintas: enquanto a produção brasileira verificou aumento constante, a de Java estacionou no patamar de 75.000 toneladas anuais. ${ }^{523}$

A motivação da vinda do holandês cafeicultor se relacionou com a Exposição Universal de Amsterdã de 1883. Nesta Exposição Laerne conheceu o café brasileiro através das amostras que lá estavam sendo expostas pela ação do Centro da Lavoura e Comércio. Em uma nota em seu impresso, a Sociedade Auxiliadora da Indústria Nacional relatou o sucesso da boa "impressão causada pela coleção dos cafés brasileiros". Sendo tão boa que "o governo neerlandês enviou ao Brasil o Sr. Van Delden Laerne $[\ldots .$.$] a fim de recolher informações desta grande$

\footnotetext{
522 Correio Paulistano, 27 set. 1883.

523 MARQUESE, Rafael Bivar; TOMICH, Dale. "O Vale do Paraíba escravista e a formação do mercado mundial do café no século XIX", op. cit., 2009, p. 372. Segundo os autores, até o século XVII, os árabes tinham o monopólio do café, sendo os holandeses os primeiros europeus a partilharem dessa ação. Em fins do século XVII a Companhia das Índias Orientais implantou seu cultivo em Java, sendo seguida pelos franceses em Reunião. Na década de 1720, quando o arbusto foi também aclimatado em colônias do Novo Mundo (Suriname, Martinica, Guadalupe), holandeses e franceses introduziram pioneiramente quantidades substantivas do gênero nos mercados metropolitanos. Idem, p. 345.
} 
cultura em nosso país"[Sic.]. ${ }^{524}$ Já Louis Couty destacou a atuação do Centro da Lavoura e Comércio nessas exposições no ato de espalhar "em toda parte milhares de amostras de café”. Essas ações do Centro da Lavoura foram muito elogiadas por Couty:

Essa associação desmente aqueles que, há três anos, pareciam não ter confiança na sua continuidade e utilidade; e a última vitória que acaba de ganhar se inscreve numa lista, já longa, de importantes trabalhados de vulgarização para o País. Tornar conhecido o primeiro produto do Brasil, apresentá-lo em Amsterdã e Trieste, em S. Petersburgo e Nova Iorque, em Berlim e Boston, em Paris, Atenas, Nice e em muitos outros lugares é também tornar conhecido o Brasil, ordinariamente tão mal apreciado ou completamente ignorado. 525

A sociedade civil se organizando, ainda que parcimoniosamente, motivava Couty. Nesse processo de organização o Centro da Lavoura e Comércio e a Sociedade Central de Imigração ganhavam espaço na análise de Louis Couty, posto que era o "Brasil mais ativo" que estava surgindo, como tanto queria o cientista francês. Esse movimento interno de associativismo seria útil na "vulgarização" dos produtos do Brasil na Europa, tornando mais conhecido o país. Esse processo se daria pelos produtos e o café ocupava condição primeira nessa organização. Divulgado o café, era preciso atrair imigrantes

524 O auxiliador, v. 52, Rio de Janeiro, 1884.

525 COUTY, Louis. "O Brasil no exterior e o Centro da Lavoura e Comércio”. (25 maio 1884). In: O Brasil em 1884, op. cit., p. 250-251. 
a fim de cultivar esse precioso fruto e seria nesta função que a Sociedade Central deveria agir.

No tempo em que permaneceu no Império, o holandês Laerne foi bem recebido pela sociedade imperial. Angariou honras do Centro da Lavoura e Comércio ${ }^{526}$ e seu relatório seria classificado, pela imprensa da época, como alvissareiro para o futuro do Brasil. ${ }^{527}$

Logo após a morte de Louis Couty em novembro de 1884, Van Delden Laerne já estabelecido em seu país, publicou nos idiomas inglês e francês Le Brésil et Java: rapport sur la culture du café en amérique, asie et afrique (1885), onde relatou os modos de produção da cultura do café nas regiões produtoras dos três continentes destacados no título do livro. A maior parte (de mais de seiscentas páginas do livro) foi dedicada à produção cafeeira do Vale do Paraíba e Oeste Paulista. No livro, Laerne asseverou que a produção cafeeira brasileira seria extinta ao mesmo tempo em que fosse abolida a escravidão. O holandês fechava o horizonte da produção cafeeira com esse diagnóstico pessimista. Para tanto, para contestar o que asseverou o holandês, a Sociedade Central recorreu aos trabalhos de Louis Couty a fim de contrapor os argumentos que maculavam a imagem do Império no exterior.

[...] oficiou-se ao Sr. conde de Villeneuve, ministro brasileiro na Bélgica, para que S. Exmo. fizesse o

526 Segundo o próprio Delden Laerne, o Centro da Lavoura e Comércio fez dele membro honorário. LAERNE, Van Delden. Le Brésil et Java: rapport sur La culture du café em amérique, asie e afrique. Paris: Challamel Ainé,1885, p. 221.

527 Correio Paulistano, 18 jan. 1884. 
favor de rebater muitas das asseverações do livro de Delden Laerne, relativas ao cultivo do café ente nós. Remeteu-se um exemplar do precioso livro do ilustre Dr. Luiz Couty Le Brésil en 1884, onde S. Exmo. Encontrará valiosíssimos dados para responder aquele escritor holandês, que procura fazer crer que o cultivo do café, no Brasil, esta fatalmente condenado a desaparecer quando se extinguir a escravidão entre nós. O Dr. Couty mostra com admirável proficiência qual o futuro daquela cultura, entregue que seja ao braço livre do imigrante e à sua inteligente iniciativa. ${ }^{528}$

A refrega ocorreu em um ambiente internacional, daí o temor resultante do que poderia ocorrer se tais informações negativas caíssem em ouvidos imigrantes, ainda que imigrantes em potencial. A boa imagem do café brasileiro na Europa era um ótimo argumento para atrair imigrantes, do contrário, estando o café com destino incerto qual imigrante se disporia a cruzar o atlântico?

O movimento de contestação realizado pela Sociedade Central torna-se importante ao mobilizar o governo, o Ministério da Agricultura, e mostrar a "conveniência de serem na exposição de Antuérpia, refutadas as asseverações do Sr. Van Delden Laerne acerca do futuro do café entre nós". Sublinhamos o aspecto do ambiente internacional das Exposições Universais, onde estava em jogo a imagem do país e de seus produtos. Num primeiro momento, na Exposição de Amsterdã, Van Delden Laerne conheceu o café brasileiro, veio ao Brasil vistoriar as produções cafeeiras e decretou um fim para o café. Em

528 A Immigração, boletim n. 11, ano 2, maio/jun. 1885 (11 maio 1885). 
num segundo momento, na Exposição de Antuérpia, suas observações sobre o café brasileiro seriam refutadas. Com esse fito se deu a ação da Sociedade Central, quando recorreu ao governo clamando a necessidade de refutar o que divulgou Laerne. A respeito disso, lembrava a Sociedade Central "quão útil fora a distribuição dos livros do finado Couty - Le Brésil en 1884 e Étude de Biologia Industrielle sur le café - naquela festa industrial”. O objetivo era pedir ao Ministério da Agricultura mais exemplares dos livros de Couty, para continuar a luta contra o holandês. Livros que "apresentam, com a maior verdade e proficiência, as esplêndidas condições do nosso país para receber imigração europeia. São obras de grande valor como elemento de propaganda" ${ }^{529}$

Outro argumento de Van Delden, que inquietou a Sociedade Central, era de que o imigrante no Brasil não se sujeitava a trabalhar no cafeeiro, não se adaptava às condições péssimas da produção. Para questionar isso, a Sociedade Central enviou ofícios aos fazendeiros "que trabalham há anos com gente europeia” para que estes enviassem pareceres acerca das condições de trabalho dos imigrantes estabelecidos em suas propriedades. ${ }^{530}$

$\mathrm{Na}$ aula inaugural do curso de botânica do Museu Nacional, o professor Dr. Collatino Marques de Souza Filho discorreu sobre a cultura do cafeeiro, tecendo algumas considerações acerca do que havia dito Laerne. Collatino após apresentar muitas amostras de café de diferentes regiões do Império, dizia que "não abraça a

529 Gazeta de Noticias, 19 maio 1885. [grifo nosso].

530 A Immigração, boletim n. 11, ano 2, maio/jun. 1885. 
opinião do Sr. Laerne sobre o futuro da cultura do café no Brasil". Para Collatino, o café "será sempre a cultura predileta de muitas zonas deste Império". ${ }^{531}$ Com efeito, o argumento de Laerne ganhou vários adversários e amiúde foram contestados.

Pela segunda vez em ambiente internacional, ${ }^{532}$ neste caso de modo indireto, as ideias de Louis Couty eram mobilizadas para restaurar a boa imagem manchada do Império na Europa. Suas qualidades de amigo do Brasil ganhavam novos significados nesta ação da Sociedade Central. Daquele momento para frente as ideias de Couty sobre o país consolidavam-se como instrumento de defesa dos interesses que a Sociedade Central defendia.

\subsection{Louis Couty e Van Delden Laerne: dois destinos para o Império}

Diante do empenho que a Sociedade Central de Imigração realizou para contestar o que havia dito Van Delden Laerne ao mobilizar os argumentos de Louis Couty, torna-se oportuno cotejar os escritos de Couty com os escritos de Laerne a fim de evidenciar o contraste entre o que ambos pesavam sobre o futuro da lavoura cafeeira.

O livro Le Brésil et Java está dividido em doze capítulos com mais cinco anexos repletos de informações e dados estatísticos sobre a produção cafeeira no mundo. Van Delden Laerne faz uma ampla descrição geológica

531 Gazeta de Notícias, 15 jul. 1885.

532 A primeira vez ocorreu com o debate entre Louis Couty e o abolicionista francês Victor Schoelcher, como já analisamos. 
do Império, se apoiando nas informações que obteve de Orville Derby a quem classificou como "o primeiro dos geólogos e paleontólogos a serviço do Brasil”. 533 Além do aspecto geológico, traz informações sobre o clima e sobre a história e a política do Brasil. Cita vários homens de ciência do Brasil e que residiam no país dos quais se valeu para compor seu livro.

O holandês menciona um diálogo que teve com Couty em que o francês havia "declarado pessoalmente" sobre a produção média do café brasileiro. Entretanto, desconsidera a maioria das asseverações de Couty, especialmente as contidas no relatório Étude de Biologie Industrielle. Nesse encontro, Laerne informa que Couty o teria alertado sobre os exageros das informações dos fazendeiros. Contudo, Laerne observa que o próprio Couty "caiu nas armadilhas" dos fazendeiros se referindo ao relatório sobre o café de 1883.534 É interessante ressaltar a atenção que Couty e Laerne tiveram em relação às informações que os fazendeiros lhes passaram. A respeito disso o holandês ao se referir aos exageros do fazendeiro cita um ditado da época que fazia dizer que quem mentia de modo exagerado "mentia como um fazendeiro". ${ }^{355}$

Como podemos perceber, as querelas entre Couty e Laerne ocorreram desde a feitura do relatório do holandês. Com efeito, é interessante notar que tanto Couty quanto Laerne tinham críticas severas aos meios de produzir o café no Império, mas Couty acreditava e, sobretudo, atuava de

533 LAERNE, Van Delden. Le Brésil et Java: rapport sur La culture du café em amérique, asie e afrique. Paris: Challamel Ainé,1885, p. 24.

534 Idem, p. 269.

535 Idem, p. 225. A menção esta na nota de rodapé da referida página. 
um lado como estudioso ligado às instituições científicas do Império, de outro lado num projeto imigrantista para o bom futuro do Império. Enquanto o holandês desacreditava que o destino do café seria promissor no futuro.

Van Delden Laerne afirma ter lido Étude de Biologie Industrielle sur le café, porém após algumas viagens e conversas com alguns fazendeiros que Couty havia conversado também, para seu pesar, dizia "ter encontrado tantas declarações imprecisas, tantos dados desmentidos” pelos fazendeiros, que "a obra do Dr. Couty, embora louvável, não era" útil "para servir como guia na composição" do seu relatório sobre a cultura cafeeira no Brasil. ${ }^{536}$ Diante disso, Laerne classificou Couty como um "cientista idealista" que aconselhava os fazendeiros, para logo em seguida se contradizer no que havia aconselhado. Nesse sentido, segundo o holandês, Louis Couty aconselhava a substituição do negro e sua enxada pela carpideira conduzida por um animal, a mula. Para em seguida dizer que "infelizmente este conselho não é aplicável em todos os lugares". Para Couty o uso da carpideira seria impossível na maioria dos cafezais de Cantagalo plantados muito próximos um do outro ou nos cafezais de dez a vinte anos de São Paulo, que são muito espessos para deixar passar uma mula entre seus ramos. ${ }^{537}$ Essa contradição no concelho de Couty evidenciada pela crítica de Laerne revela que Couty tinha um foco bem definido sobre a produção cafeeira, a substituição do trabalho do negro escravizado por máquinas ou instrumentos aratórios e,

536 Idem, p. 220-221.

537 Idem, p. 237-238. 
sobretudo, pelo imigrante europeu. Contudo, ao observar que a carpideira e o arado não seriam possíveis nos cafezais cujos pés eram muito próximos ou que eram muito copados, espessos pela idade superior a dez anos, ${ }^{538}$ Couty estava abrindo possibilidades para novas formas de cultivo, a fim de facilitar o uso da carpideira e do arado em substituição ao trabalho do escravo. A substituição do trabalho escravo era seu objetivo, mas antes de ser essa substituição abrupta e danosa, era preciso adequar a produção a uma nova modalidade de transformação do solo.

Van Delden Laerne acreditava que a continuidade da escravidão era o que impedia a corrente de imigrantes para o Império. Dizia ele que "Tout repose sur le travail d'esclaves" ${ }^{539}$ Diante disso, a abolição seria a ruína do país e seria sobre essa ruína que se reconstruiria o futuro do Brasil. Laerne acreditava que a imigração seria a solução também, mas que tudo dependia da legislação agrária que até então tinha se oposto à imigração e colonização, referia-se à Lei de Locação de Serviços de 1879. ${ }^{540}$ Já Louis Couty, via as transformações que os imigrantes vinham realizando pelas regiões cafeeiras que visitou: "é fácil uma observação geral: o escravo parou por todos os lugares, ou quase todos os lugares, de ser o único trabalhador”, em São Paulo ou Cantagalo “já se via o trabalhador livre". ${ }^{541}$ Esta visão da paisagem e

538 COUTY, Louis. Étude de biologie industrielle sur le café, op. cit., 1883, p. $27-28$.

539 “Tudo repousa no trabalho escravo". Tradução livre. LAERNE, Van Delden. Le Brésil et Java, op. cit., 1885, p. 73.

540 Idem, p. 74.

541 COUTY, Louis. Étude de biologie industrielle sur le café, op. cit., 1883, p. 116. 
construção narrativa que favorecia a transformação do trabalho escravo para um trabalho livre tornou-se operante em favor dos interesses reformistas via imigração. Por esse aspecto que a Sociedade Central recorreu às argumentações de Louis Couty para contrapor Van Delden Laerne. Enquanto que Laerne fechava o horizonte, Couty abria demonstrando a existência de um fluxo imigratório para o Império, ou trabalhando em favor desse fluxo. O contraponto principal no argumento de Couty que opera a crítica da Sociedade Central contra Laerne se encontra no modo como Louis Couty projeta um futuro para o Império. Para ele o destino do Brasil estava garantido com a vinda de imigrantes europeus. A transformação que a introdução da mão de obra livre realizaria no país proporcionaria grandes resultados e o pouco que por Couty fora visto deixou-o animado: "o comércio externo aumentou; o papel do escravo diminuiu, o do assalariado começa" ${ }^{542}$ Quiçá fosse em referência a essas argumentações favoráveis ao futuro do Império que motivou Laerne a considerar Couty um "cientista idealista".

No movimento realizado pela Sociedade Central de Imigração para contrapor o diagnóstico pessimista de Van Delden Laerne, não foi sublinhado nenhum trecho em especial, mas podemos deduzir que a frase "Ignoro se sou pessimista. Posso ser, porque considero a situação atual do Brasil como extremamente perigosa, cheia de perigos" 543 tenha provocado a revolta nos membros da Sociedade Central. O mais agravante se dava no modo de relatar as relações entre fazendeiros e colonos:

542 Idem, p. 117.

543 LAERNE, Van Delden. Le Brésil et Java, op. cit., 1885, p. 79. 
"acostumados ao tratamento dos escravos, ele não hesita em interferir nos assuntos internos do colono" e resumia "em uma palavra, ele considera o colono mais como um subordinado, menos como um trabalhador livre". ${ }^{444}$ Nada mais desabonador para os destinos da imigração no Brasil do que uma contrapropaganda como esta. Se for para não ser um trabalhador livre o que levaria o colono a emigrar para o Brasil, poderiam indagar os reformistas da Sociedade Central. Já Couty acreditava no futuro com a imigração, todo país novo como o Brasil, dizia ele, necessita de "povoar-se livremente, com imigrantes europeus livres, ativos [...]".545 Apesar de apontar várias falhas no processo de atração e condução da imigração, dizia não existir "melhor prova de nossa confiança no futuro do Brasil do que o fato de que, na medida de nossas forças, procuramos ajudar a prepará-lo?”. Era a fala de um homem de ciência que balizava as boas condições do país para receber imigrantes ao corroborar "a mais absoluta confiança no futuro do Brasil”. Para alcançar esse futuro dizia ter apenas "dúvidas quanto aos meios pelos quais esse futuro será alcançado [...]”, mas tinha certeza que só com o povoamento, com a colonização, esse futuro se realizaria pleno, pois "baseados em fatos de observação”, ou seja, na prática, "nenhum país oferece ao trabalho do homem um campo de atividade mais vasto e mais lucrativo" como o Brasil. ${ }^{546}$

544 Idem, p. 115.

545 COUTY, Louis. "Exploração e colonização”. (4 a 11 nov. 1883). In: O Brasil em 1884, op. cit., 1984, p. 82.

546 COUTY, Louis. "As culturas do Brasil e seu rendimento". (10 a 13 de abr. 1884). In: O Brasil em 1884, op. cit., 1984, p. 101. 
Para Van Delden, abolida a escravidão, "a agricultura deverá regredir sem uma imigração em grande escala”, uma vez que, segundo o holandês, a população negra não iria produzir nada além do necessário para o seu próprio sustento. ${ }^{547}$ Nesse aspecto, Couty tinha a mesma opinião de Laerne, mas o francês abria as possibilidades do Brasil para a imigração, se empenhava em mostrar um país apto a receber tal colono e, sobretudo, trabalhava com seus artigos no convencimento de que era preciso reformas que garantiriam o maior fluxo de imigrantes para o Império.

O motivo que trouxe Laerne ao Império foi ter se deparado com algumas amostras de um café de uma qualidade que, segundo ele, se assemelhava ao "artificial". A partir disso, algumas questões surgiram: "Aquelas qualidades superiores são encontráveis no mercado? Não seriam as amostras o resultado de um trabalho aturado de separação e de um beneficio que não é o usual?"548 [sic]. Essas questões que Laerne relatou ao Correio Paulistano podem ter servido de guia em sua vistoria na produção cafeeira. O fato é que após a vistoria dizia ele ser de "conhecimento geral que a cultura cafeeira neste país atravessa uma crise que ameaça seu futuro", mas que não era a "maneira de cultivar que causou a crise", e sim "exclusivamente a falta de braços [...]" ${ }^{549}$ Delden Laerne não entendia que o problema da crise estivesse na qualidade da mão de obra, como entendia Couty, mas na falta dela. A respeito disso, uma entrevista que ele concedeu ao Correio Paulistano traz alguns dispositivos interessantes

547 LAERNE, Van Delden. Le Brésil et Java, op. cit., 1885, p. 119.

548 Correio Paulistano, 18 jan. 1884.

549 LAERNE, Van Delden. Le Brésil et Java, op. cit., 1885, p. 238. 
que o governo holandês elaborou para controlar a mão de obra nativa na ilha de Java.

O sistema de trabalho atual pode ainda prolongar-se por muitos séculos [na ilha de Java]. O governo holandês envolveu na hábil hierarquia dos seus funcionários os chefes indígenas que sobre a população tem todo o prestígio da raça, das tradições e da religião. Por meio deles, encontra a metrópole sempre obediência. É prova disso o fato de conservarem os holandeses, na ilha, uma força europeia insignificante. Não há perigo visível de a população operária recusar-se a prestar os seus serviços pela maneira porque o faz atualmente. ${ }^{550}$

Enquanto o destino da lavoura brasileira estava fadado à ruína, pois sem mão de obra com a possibilidade da abolição, sem o negro liberto interessado em trabalhar, sem a imigração europeia condenada pelo modo de tratamento que o fazendeiro praticava para com o colono, só um destino estava reservado ao Império, a ruína. Enquanto que em Java um hábil sistema de controle prolongaria por muitos séculos um sistema de trabalho que garantia preços baixos ao café de Java.

O terreno já está preparado, o serviço pesado fora realizado pelos escravos. Podem vir os imigrantes.

Os imigrantes podem vir sem medo. A região dos cafezais é também a região alta, a das planícies. Eles encontrarão um clima bom; sua saúde será excelente. Encontrarão também culturas já prontas,

550 Correio Paulistano (18 jan. 1884). A chamada para a entrevista foi muito vistosa, em letras garrafais dizia: "JAVA CULTURA E COMÉRCIO DO CAFÉ”. 
providas de caminhos, rebanhos e usinas. Graças aos anteriores esforços dos infelizes pretos, será imediato o resultado dos recém-chegados, assalariados, meeiros ou pequenos proprietários. Eles não terão de arrotear nem de plantar. Além disso, o resultado desse trabalho será superior a tudo que se possa imaginar, o quíntuplo ou sêxtuplo do das culturas de cereais, o dobro ou triplo do das culturas de videiras. ${ }^{551}$

O trecho acima ilustra porque Louis Couty foi a referência conceitual utilizada pela Sociedade Central de Imigração para refutar o pessimismo de Van Delden Laerne quanto ao futuro do café e, por consequência, da imigração para o Império. Couty trabalhou um projeto pessoal de imigração que serviria para o Império, se dedicou ao atuar nas questões que o afetavam de perto, o estrangeirismo que ele tanto criticou, se dedicou nas questões propondo reformas, com efeito, não adiantava vir imigrantes para continuar a reprodução de um passado, para serem contratados e reproduzir o que fazia o escravo na fazenda. Isto era o que ele chamou de "obstáculo moral", que independiam das leis, pois estavam baseados nos costumes e nos "hábitos antigos decorrentes da escravidão". Para solucionar os problemas "somente a pequena propriedade ou o salariado poderão corrigir o mal porque libertarão completamente o agricultor". ${ }^{552}$ Esse uso de Louis Couty pela Sociedade Central de Imigração revela o quanto as ideias do cientista francês

551 COUTY, Louis. "As culturas do Brasil e seu rendimento". (10 a 13 abr. 1884). In: O Brasil em 1884, op. cit., 1984, p. 102-103.

552 COUTY, Louis. "A colonização e os grandes proprietários". (27 dez. 1884). In: O Brasil em 1884, op. cit., 1984, p. 116. 
agradavam e se adequavam à um projeto reformista idealizado por um grupo formado pelos mais destacados nomes das letras, ciência e política imperial.

Em fevereiro de 1886, a Sociedade Central permanecia na luta contra as asseverações de Delden Laerne. Com efeito, alterava o foco e solicitava ao Centro da Lavoura e Comércio o livro do holandês "para melhor servir os desejos da sociedade". ${ }^{553}$ A Sociedade Central teve seus esforços concentrados nas atividades de propaganda que podem ser divididas em dois niveis: um interno e um externo. No nivel externo, as ações destinavam-se ao imigrante e aos governos envolvidos. No nível interno, visava convencer a sociedade brasileira da utilidade da imigração como solução dos problemas nacionais. ${ }^{554}$ Essa contenda internacional entre Louis Couty e Van Delden Laerne mediada pela ação da Sociedade Central pode ser apreendida como uma primeira fase da recepção das ideias imigrantistas de Louis Couty no programa reformista da Sociedade Central, se enquadrando como uma ação externa da Sociedade Central. Uma segunda fase da recepção e consolidação do seu pensamento no programa de reformas da Sociedade Central aparece em 1887 com a publicação de um livro póstumo de Louis Couty pela Sociedade Central. Além disso, em outras questões Louis Couty será mobilizado como referência conceitual, especialmente no que se refere à imigração chinesa, tão contestada pelo grupo reformista imigrantista. A publicação do livro póstumo de Couty se enquadra como uma ação

\footnotetext{
553 A Immigração, ano 3, boletim n. 18, fev. 1886.

554 VASSILIEFF, Irina. A Sociedade Central de Imigração nos fins do século XIX, op. cit., 1887, p. 11.
} 
interna, que visou convencer a sociedade da importância da imigração.

5.6 Pequena propriedade e imigração europeia: a consolidação do pensamento de Louis Couty no programa da Sociedade Central de Imigração

O ano de 1887 foi o de maior atuação da Sociedade Central ${ }^{555}$ e nesse mesmo ano foi publicado pela Sociedade Central o livro Pequena propriedade e imigração europeia, com introdução de Alfredo d'E. Taunay e notas de André Rebouças, os dois mais icônicos membros da Sociedade Central. No boletim 33 de seu impresso, a Sociedade Central trazia a público o aviso do Ministério da Agricultura comunicando a solicitação junto ao Ministério da Fazenda a "ordem afim de, na Imprensa Nacional, ser impresso o livro do falecido Dr. Louis Couty" [sic]. O mesmo boletim informava que a Sociedade Central "não podia prestar mais sincera e respeitosa homenagem à memória desse vulto da ciência, do que se empenhando pela publicação de sua última obra". ${ }^{556} \mathrm{O}$ livro é a reunião de um texto relativamente curto de Louis Couty, somados à introdução de Taunay, às notas de Rebouças e alguns anexos relativos ao programa da Sociedade Central e um discurso de Taunay. Constituía-se, portanto, em um verdadeiro livro de propaganda das ideias e ações imigrantistas de um setor da sociedade imperial.

555 Idem, p. 11.

556 A Immigração, ano 4, boletim n. 33, jun. 1887. 
O Século XIX, sobretudo sua segunda metade, foi caracterizado como o século da ciência e do progresso tecnológico que incutiu transformações sensíveis à sociedade em todos os níveis e lugares. Segundo a historiografia que analisou as questões da imigração privilegiando a Sociedade Central como objeto, pode-se inserir a referida sociedade nesse contexto histórico da expansão da ciência e das inovações tecnológicas entendendo a ação da Sociedade Central num processo de aparecimento da grande propaganda moderna. ${ }^{557}$

No âmbito da propaganda, a Sociedade Central utilizou as ideias de Couty para dar movimentos às ideias e ações imigrantistas que visavam reformas. A Sociedade Central se valeu de um intenso repertório de ideias e agentes que proporcionavam o movimento dos interesses pela ação na imprensa, pelos livros e conferências. Nesse cenário de um amplo espaço público em que se discutiam os destinos do país, Louis Couty ao estruturar suas ideias em seus textos, livros, relatório, vai elaborar seu projeto e nutrir um repertório farto e favorável aos interesses imigrantistas que foi mobilizado pela Sociedade Central. Portanto, Couty entra nesse processo como um agente importante que instrumentalizou o repertório crítico da Sociedade Central com seus argumentos científicos/modernos. Desse modo, o livro Pequena propriedade e imigração europeia é a sistematização das ideias de Couty no programa da Sociedade Central. Neste livro podemos apreender com quais finalidades a referida Sociedade Central mobilizou o repertório de Couty

557 VASSILIEFF, Irina. A Sociedade Central de Imigração nos fins do século XIX, op. cit., 1887, p. 186-187. 
para empreender ações e conscientizar a sociedade da necessidade da imigração.

O movimento imigrantista de final dos oitocentos constituiu-se no ritmo de novas necessidades, como formar e esclarecer a opinião pública da necessidade da imigração. ${ }^{558}$ Contudo, para atrair o imigrante europeu era preciso alterar a imagem negativa que sombreava o Império, sobretudo a de que no Brasil só se procurava ver "nos trabalhadores europeus substitutos do negro" como observou o então deputado Alfredo Taunay. ${ }^{559}$ Nesse aspecto, todo empenho da Sociedade Central contra o que disse Van Delden Laerne se insere na mesma questão de alterar a imagem do país na Europa.

Na história da extinção da escravidão e da penosa transformação do trabalho nesta parte do mundo, esforço que sem duvida granjeará para o Império Americano a admiração e as bênçãos da filosofia e da humanidade, o nome do Dr. Louis Couty há de figurar em lugar de honra, e de quantos documentos se poderão compulsar com vantagem para reconstituir esse curioso e interessante período de duvidas e temores, contrabalançados por muito entusiasmo no futuro e muita fé nas grandes causas, o opúsculo ora publicado e o livro Le Brésil en 1884 proporcionarão os meios mais seguros de elucidação e estudo. ${ }^{560}$

\footnotetext{
558 Idem, p. 187.

559 Anais da Câmara dos Deputados do Império do Brasil. 10 a Sessão. 18 Legislatura. Rio de Janeiro, Tipografia Nacional, 1884, v. 5. Apêndice, p. 547, apud VASSILIEFF, Irina. A Sociedade Central de Imigração nos fins do século XIX, op. cit., 1887, p. 196.

560 TAUNAY, Alfredo d'E. “Louis Couty: esboço biográfico”. In: COUTY, Louis. Pequena propriedade e imigração europeia. Obra póstuma anotada e precedida de uma introdução biográfica por Alfredo d'E. Taunay.
} 
Quando a fonte direciona sua fala ao futuro algo de interessante pode ser visualizado, neste caso o que disse Alfredo de Taunay no trecho acima sobre a então recente memória de Louis Couty revela ao mesmo tempo a monumentalização de Louis Couty, ou seja, a sistematização das ideias do cientista francês em favor dos interesses da Sociedade Central e também revela um fato, o de que Couty atuou de modo ativo nas questões da mão de obra e por isso que a Sociedade Central sistematizou suas ideias em seu programa de ação. Cabe apreender essa sistematização das ideias de Couty realizadas pela Sociedade Central e apontar como os realizadores dessa obra enfatizaram certas questões em favor de suas ações.

Este texto de Louis Couty foi escrito entre os anos de 1883 e 1884, em um momento em que o cientista francês publicava uma miríade de artigos e relatórios sobre o café, imigração, colonização e etc., abarcando toda a complexidade das questões relativas à mão de obra. Por ser um livro que destoa das demais publicações de Couty, sobretudo, porque foi um livro póstumo, sendo um documento da recepção das ideias de Couty e um monumento à sua memória. Com efeito, se tomássemos esse livro no início de nossa análise cometeríamos o deslize de analisar o pensamento de Couty de um ponto de vista retrospectivo e não diacrônico como estamos realizando.

A frente de luta da Sociedade Central de Imigração se orientava por reformas que visavam facilitar a naturalização, o casamento civil e revogação da Lei de Locação de Serviços de 1879. Por outro lado, havia um setor na

Rio de Janeiro: Imprensa Nacional, 1887, p. 4. 
organização que elaborava um projeto mais completo de reformas que incluiam a pequena propriedade e o imposto territorial, formando a chamada "democracia rural". Este setor, por sua vez, visava ao triunfo de um projeto modernizador avançado, embora não revolucionário. ${ }^{561}$ Entendemos que foi o setor da democracia rural que selecionou o texto em que Couty tratou mais do papel da pequena propriedade e da imigração europeia e o publicou.

Nesse texto publicado em 1887, Couty analisou com mais acuidade a mentalidade do fazendeiro apegado à escravidão, o fazendeiro do passado, aquele que impedia o desenvolvimento da pequena propriedade e da imigração ao prolongar as características escravocratas. Nesse aspecto, o livro de Couty seria de grande valia aos interesses da Sociedade Central. Contudo, é importante enfatizar que na análise geral que Couty fez da expansão cafeeira do Rio de Janeiro e de São Paulo ele vai caracterizar aquele espaço de experiência da lavoura cafeeira em dois regimes distintos de tempos simbolizados pelas ações dos fazendeiros do passado e do futuro. Nesse artigo que compõe o livro Pequena propriedade e imigração europeia, Couty se aprofunda na crítica aos fazendeiros do passado e demonstra o quanto eles ao prolongar o passado da escravidão, não tiveram a habilidade de transformar o trabalho escravo em trabalho livre ao não atrair o imigrante europeu. Por outro lado, Couty sempre demonstrou admiração para com os fazendeiros do futuro, os fazendeiros de São Paulo. Após analisar uma

561 VASSILIEFF, Irina. A Sociedade Central de Imigração nos fins do século XIX, op. cit., 1887 , p. 11. 
carta em que Antonio Prado mostrava a importância da imigração e da permanência dos imigrantes, Couty respondia àqueles que

nos acusam de falar às vezes bem demais dos fazendeiros e exagerar a nossa simpatia, considerando os grandes proprietários como a força viva nacional mais capaz de resolver a crise do trabalho, sobre as explorações, sobre as próprias culturas e não sobre as palavras. ${ }^{562}$

Por isso é importante clivar o que Couty pensou em uma estrutura coesa de informações e o que foi apropriado pela Sociedade Central de Imigração em sua ação. Segundo a caracterização de Vassilieff, o projeto da Sociedade Central não era uno e estruturado, com algumas exceções, era fragmentário e desalinhado. ${ }^{563}$ Sob essa forma fragmentária do projeto da Sociedade Central a apropriação das ideias de Couty foi facilitada.

$\mathrm{Na}$ análise da mentalidade do fazendeiro do passado feita por Couty fica visivel o uso da Biologia Industrial para caracterizar esse homem do passado. Para Couty, o prejuízo da grande propriedade, baseada em um trabalho coletivo forçado era ainda geral entre os fazendeiros mais distintos. Eles formavam a maioria dos proprietários que doze anos depois da Lei Rio Branco (1871) aceitavam a ideia da emancipação sem ter que converter à

562 COUTY, Louis. "A colonização e os grandes proprietários”. (27 dez. 1883). In: O Brasil em 1884, op. cit., 1984, p. 114.

563 VASSILIEFF, Irina. A Sociedade Central de Imigração nos fins do século XIX, op. cit., 1887 , p. 3. Segundo a autora, o quadro de membros da Sociedade Central era muito diversificado, composto por republicanos e abolicionistas como José do Patrocínio. 
necessidade do trabalho livre. A fazenda, para esses fazendeiros do passado, continuava a ser "uma entidade sagrada” intocável, "tanto é verdade que as características psíquicas são ainda estáveis, quanto as características zoológicas". ${ }^{564}$ Apesar de considerar que não havia consenso quanto ao modo de substituir o trabalho escravo, "se é fácil suprimir o escravo", porém "ninguém sabe como organizar a mão de obra livre”, 565 Couty acreditou que o ordenamento da substituição do trabalho escravo pelo trabalho livre caberia ao fazendeiro num processo que tinha iniciado com a Lei do Ventre Livre em 1871. Contudo, até 1883 os grandes proprietários não tinham feito nada em favor do ato de 1871 e "eles não vão fazer nada mais por causa de sua natureza social, por causa de seus hábitos intelectuais e mentais”. Aqui o determinista Couty atribuía à mentalidade do fazendeiro, eivada por sua educação "no meio dos escravos", o óbice à "transformação necessária”. Todavia, a crítica não cai de forma direta ao fazendeiro, mas ao regime da escravidão, ao negro, ao contato entre senhor e escravo que numa "mestiçagem moral" contaminava os hábitos dos fazendeiros que "inconscientemente" fazem de tudo para permanecer com o trabalho do escravo. ${ }^{566}$

O fazendeiro se preocupava em dar a melhor educação a seus filhos, "ele quer" que "seus filhos estudem na faculdade, e mais tarde se tornem advogados, médicos,

564 COUTY, Louis. Pequena propriedade e imigração europeia, op. cit., 1887, p. 35-36.

565 COUTY, Louis. A escravidão no Brasil, op. cit., 1988, p. 68.

566 COUTY, Louis. Pequena propriedade e imigração europeia, op. cit., 1887, p. 51 . 
engenheiros", aí como em outros pontos o grande proprietário mostra inteligência, chegando a ter "mais espírito de progresso que a maioria dos grandes proprietários da França ou alhures”. Contudo, observava Couty num diálogo com Sílvio Romero, "seus filhos passam os primeiros anos no meio dos negros, sem ideia de família e de sociedade". A mulher que amamenta a criança branca é negra, les bonnes du premier âge ${ }^{567}$ são negros. Tudo isso produz "un véritable métissage moral". Esta fala não é minha, dizia Couty, "mas de um brasileiro que conhece e honra seu país, Sílvio Romero”. Mestiçagem moral que por sua conta Couty julgava "absolutamente nociva". 568

Essa "mestiçagem moral” dos grandes proprietários impedia o incremento de inovações tecnológicas, da vinda de imigrantes, impedia, pensando com Couty, o desenvolvimento do país. E teria sido, para Couty, a "mestiçagem moral" que levou os fazendeiros a "não corresponderam às expectativas dos legisladores de 1871".569 Alguns comentários ditos por grandes proprietários que se opunham à imigração descortinavam a mentalidade dos fazendeiros apegados à terra. Dizia um fazendeiro, para o espanto de Couty, que preferia "deixar morrer" seus "cafezais a ter relações com colonos desobedientes e grosseiros". Enquanto que outro dizia que seus filhos poderiam fazer o que quisessem, mas tendo vivido com os escravos, não poderiam acostumar a outro

567 “Trabalhador doméstico dos primeiros anos”. (tradução livre).

568 COUTY, Louis. Étude de biologie industrielle sur le café, op. cit., 1883, p. 114 .

569 COUTY, Louis. Pequena propriedade e imigração europeia, op. cit., 1887 , p. 34. 
trabalhador. ${ }^{570}$ Essa mentalidade do fazendeiro, era para Couty fruto do contato cotidiano entre senhor e escravo e apegados a uma única forma de trabalho tinham como ídolo a fazenda, "uma entidade sagrada” e intocável. Esses eram os fazendeiros do passado, "tanto é verdade que as características psíquicas são ainda estáveis”. ${ }^{571}$

Esses argumentos de Louis Couty contrários à grande propriedade são direcionados a um grupo específico de fazendeiros, os fazendeiros que eram incapazes de transformar a mão de obra escrava em mão de obra livre, isto é, incapazes de desapegar de um sistema que apenas prolongava o passado. O pensamento de Couty em relação aos fazendeiros do futuro era diferente, pois nutria admiração e considerava os cafeicultores de São Paulo os homens mais aptos a transformar a mão de obra e o país.

Desta forma, fica evidenciada a seleção de um texto específico de Couty por parte da Sociedade Central, cuja finalidade era criticar os grandes proprietários que não queriam dividir a terra e convencer a população letrada que a grande propriedade era um entrave às reformas que o país necessitava. O trecho abaixo de Louis Couty demonstra o quanto ele serviu aos interesses da Sociedade Central.

O fazendeiro prefere abandonar sua plantação em vez de vendê-la; este grande proprietário apesar das suas qualidades, ou por causa de suas qualidades, me parece incapaz de fazer ele mesmo a transformação necessária; e, além dessa resistência longa e contínua, como também de outras

570 Idem, p. 35.

571 Idem, p. 35-36. 
condições do meio social, criam à colonização da terra cultivada uma série de dificuldades, que precisam ser consideradas. ${ }^{572}$

Esta frase recebeu os melhores elogios de André Rebouças que alçou Couty ao nivel de eminentes cientistas do século XIX. Dizia ele que bastaria "este parágrafo para colocar Louis Couty ao lado de Charles Darwin, de Agassiz, e dos mais elevados gênios que hão visitado o Brasil". ${ }^{573}$ Tudo estava preso, asseverava Rebouças, "dentro do circulo do monopólio da terra, agravado pela negra escravidão". ${ }^{774}$ Contudo, apesar de Couty propor a divisão das grandes propriedades em pequenas propriedades ele enfatizava que no Brasil "o solo precisava do homem", ou seja, a primeira questão a ser resolvida não era a da terra, mas a do homem que trabalharia a terra. E esse homem só teria uma origem, a europeia, sobretudo, porque Couty desprezava a utilização do trabalho do negro como elemento ativo, posto que para ele o negro não possuía regularidade no trabalho, especialmente num ambiente de pós libertação. O problema da grande propriedade para Couty não era a sua primeira questão, sua primeira questão, desde o início, foi a da mão de obra que ele considerava cara e ruim. Nesse aspecto, sua admiração para com alguns fazendeiros precisa ser considerada,

\footnotetext{
572 Idem, p. 51.

573 André Rebouças auxiliou Alfredo d'E. Taunay na elaboração das notas para o livro póstumo de Louis Couty. COUTY, Louis. Pequena propriedade e imigração europeia, op. cit., 1887, p. 88.

${ }^{574}$ COUTY, Louis. Pequena propriedade e imigração europeia, op. cit., 1887 , p. 88. A questão do monopólio da terra era central para Rebouças, dizia ele que quando o problema da terra esta errado, tudo esta errado, tudo vai mal. (Idem, p. 233).
} 
sobretudo a admiração para com os fazendeiros paulistas. Para compreender melhor o pensamento de Couty, podemos inverter a frase de Rebouças e dizer que tudo estava preso dentro do circulo da escravidão, agravada pelo monopólio da terra. A preocupação de Couty era com a produção agrícola brasileira. Com isso, notava que "o sistema atual de cultivo do café, baseado na escravidão, implica ao fazendeiro múltiplos inconvenientes, restringe seus ganhos, diminui sua riqueza, atrapalha o desenvolvimento social" ${ }^{575}$

A boa crítica de Rebouças, somada à boa crítica de Taunay exerceram função estratégica na consolidação de Louis Couty como uma referência conceitual no pensamento imigrantista brasileiro, sobretudo, no contexto das discussões sobre as necessidades de reformas via imigração.

\subsection{A luta contra a imigração chinesa}

A Sociedade Central de Imigração não poupou esforços na campanha que empreendeu contra a imigração de chineses para o Brasil. Era uma honra para o grupo da Sociedade Central rechaçar esses imigrantes classificados como indesejados.

O trabalhador chinês foi visto, no longo debate sobre o trabalhador ideal, como um mau elemento em todos os níveis. Essa recusa do chinês foi defendida por Lacerda Werneck na década de 1850 se apoiando em

\footnotetext{
575 COUTY, Louis. Étude de biologie industrielle sur le café, op. cit., 1883, p. 114.
} 
generosos argumentos a fim de salvar o "destino da raça brasílica". ${ }^{576} \mathrm{Na}$ escala mental das raças que acompanhava o intelectual eurocêntrico, os chineses e os negros eram caracterizados como inferiores ao branco europeu.

No argumento favorável ao uso de chineses estava com a palavra Quintino Bocaiuva que via nos chins a alternativa de manutenção dos status quo da grande propriedade. Apenas através de tal meio seria possível promover o desenvolvimento da propriedade rural sem alterar sua forma e essência. Com a mesma direção favorável aos chins Xavier Pinheiro realizou estudos, enviado ao Ministério da Agricultura em 1869, em que indicava o sucesso da imigração chinesa em Cuba. ${ }^{577}$

Lamentando as ações dos fazendeiros do passado, dizia Couty que "muitos admitem ingenuamente" querer contratar os trabalhadores asiáticos. Favoráveis à introdução de chineses queriam eles "continuar o passado sob formas pouco diferentes". ${ }^{578}$ Sobre isso comentava Taunay:

Não há uma só palavra do Dr. Louis Couty, que não seja expressão rigorosa da verdade. Para muita gente ainda, a perspectiva mais risonha aos destinos do país é a importação do chim, e não pouco influi para esse conceito a possibilidade de

576 GONÇALVES, Paulo Cesar. Migração e mão de obra: retirantes cearenses na economia cafeeira do centro-sul (187-1901). São Paulo: Associação Editorial Humanitas, 2006, p. 86.

577 GONÇALVES, Paulo Cesar. Mercadores de braços, op. cit., 2012, p. 166. 578 COUTY, Louis. Pequena propriedade e imigração europeia, op. cit., 1887, p. 35-37. Mencionado uma conferência que realizou em 1882 na Escola Politécnica, Couty também chamava atenção para o fato do trabalho do amarelo ser "economicamente e socialmente nocivo". In: COUTY, Louis. Étude de biologie industrielle sur le café, op. cit., 1883, p. 125. 
castigar o trabalhador asiático e dar-lhe pauladas com bambu, quando ele se mostrar recalcitrante às exigências do trabalho $[\ldots] .{ }^{579}$

Taunay se vangloriava do combate que a Sociedade Central exerceu contra a imigração de chineses, "o Brasil há de um dia reconhecer este relevantíssimo serviço" dizia ele. Para aqueles que queriam macular "o solo da pátria com o nojento elemento", Taunay dizia ser, tal ato, "crime de leso-americanismo!". 580

Para questionar as medidas dos organizadores do Banco de Imigração, em seu destino civilizador, a Sociedade Central mobilizou novamente Louis Couty para convencer esses organizadores do ato nocivo que estariam cometendo caso o país recebesse os imigrantes chineses que se pretendia trazer. Abandonada a ideia de atrair imigrantes chineses pelos organizadores do Banco de Imigração, a Sociedade Central deu nota do ato comemorando a importância desse acontecimento e para tanto demonstra que Couty foi útil no argumento contrário ao imigrante chinês.

Muito provavelmente também mais detido se acharam V.V. Exs. no exame mais detido e aprofundado da questão e nas dificuldades a ela inerentes, de acordo com as ponderações expedidas, em seus belos estudos econômicos e sociais, pelo genial Luiz Couty, que demonstrou quanto o chim ficaria caro ao fazendeiro, o qual, além do salário obrigatoriamente elevado, teria de suportar o desfalque das mortes e moléstias que ceifam

579 COUTY, Louis. Pequena propriedade e imigração europeia, op. cit., 1887, p. 76.

580 Idem, p. 76. 
e acometem essa raça com muito mais frequência do que outra. Previu o ilustre publicista a fuga parcial, já em massa das fazendas, e a invasão à formiga ou subitamente dos grandes centros de população, onde esses refugiados viriam provocar irremediáveis males aos operários brasileiros e estrangeiros, perturbando as leis econômicas a que estão presentemente sujeitos. ${ }^{581}$

Além de ações mediadas por ofícios e discussões na imprensa, em 28 de outubro de 1888, a Sociedade Central realizou um encontro para se posicionar, ainda mais, contra a introdução de imigrantes chineses no Brasil. O local das discussões foi no Teatro Recreio Dramático. José do Patrocínio realizou uma conferência onde repudiou a vinda dos chins para o Império. Para José do Patrocínio "o chim é incompatível com a nossa nacionalidade, não só por motivos étnicos, biológicos, mas é um péssimo fator econômico". 582

No debate sobre o uso do imigrante chinês estavam postas duas visões: a de permanência e a de ruptura. De permanência da grande propriedade que continuaria o passado sob formas diferentes, como dizia Couty. De ruptura com o monopólio da terra, com a monocultura e com a escravidão, visando a modernização do país pela imigração seletiva do europeu.

Ao dar materialidade em suas ideias através de seus textos, Louis Couty deixou um tecido de afirmações que organizadas revelam um projeto imigrantista para o

\footnotetext{
581 A Immigração, ano 6, boletim n. 53, jan. 1889.

582 A Immigração, boletim 53 apud VASSILIEFF, Irina. A Sociedade Central de Imigração nos fins do século XIX, op. cit.,1987, p. 312.
} 
Império. ${ }^{583}$ Suas ideias sobre a transformação do trabalho interviram diretamente ampliando o debate sobre o futuro da lavoura cafeeira, o futuro do país. Sobretudo, tornou-se uma referência conceitual ao elaborar argumentos favoráveis à imigração europeia com o escopo da modernização. Elaborou uma chave interpretativa da realidade brasileira de final do século XIX, que ampliou sua intervenção nas questões da época, aliando o aspecto econômico e sociológico com o biológico na nova disciplina que a ele foi atribuída a função de professor, a Biologia Industrial. Com essa chave em mãos, Couty adentrou nos debates públicos sobre a mão de obra, ultrapassou as funções de professor e pesquisador. Não se restringiu ao aspecto das moléstias e dos preços do café, do solo, dos venenos das plantas e animais, foi além e forjou também uma interpretação ativa em seu tempo sobre o povo brasileiro. A proximidade de Couty com membros da Sociedade Central, sua ação em defesa da imagem do país, levou a Sociedade Central a se apropriar das ideias de Couty em um movimento que tinha a finalidade de contestar os argumentos daqueles que maculavam a imagem do país, como no caso Van Delden Laerne. Posteriormente, a Sociedade Central, ao mesmo tempo em que ressaltava as

583 Segundo John Pocock, para o historiador do pensamento "talvez haja” apenas duas maneiras de abordar o estudo de um documento. Pode-se considerá-lo "como um tecido de afirmações, organizadas por seu autor em um único documento, mas acessiveis e inteligíveis tanto se tiverem como se não tiverem sido harmonizadas em uma única estrutura de significado. A meta do historiador é, agora, o resgate dessas afirmações, estabelecimento dos padrões de discurso e pensamento que compõem os vários contextos em que eles se tornaram inteligíveis e a busca de quaisquer mudanças no emprego normal desses padrões que possam ter ocorrido em resultado das afirmações feitas”. POCOCK, John A. G. Linguagens do Ideário Político, op. cit., 2003, p. 245. 
características de estudioso do tema das transformações do trabalho, se valia dessa autoridade de Couty para agir e afirmar seus projetos reformistas. Isto se sucedeu com a publicação do livro Pequena propriedade e imigração europeia. Podemos entender as ideias de Couty organizadas por ele em seu momento e essas ideias sendo selecionadas pela Sociedade Central e mobilizadas visando uma ação que, no caso deste livro, era a de convencer a sociedade brasileira da necessidade da imigração europeia. Com essa ação da Sociedade Central, as ideias de Couty sobre a necessidade da imigração ganhavam respaldo de um grupo que agiu sobremaneira na luta pela imigração europeia e se consolidavam no programa de ação da Sociedade Central de Imigração. Desse modo, a recepção de suas ideias revela que ele escreveu em uma linguagem partilhada com seus coevos imigrantistas. 


\section{Considerações finais: Allons, c'est bien fini!}

O Dr. Couty era sinceramente dedicado à causa do progresso do Brasil. Não o fazia por causa própria de escritor; não se apresentava como um salvador; amava o progresso pelo progresso, e para ele tanto valia o próprio esforço como o alheio, contanto que tendesse ao mesmo fim. Viesse de onde viesse uma ideia ou uma reforma útil, o Dr. Couty aplaudia-a e consubstanciava-se com ela. ${ }^{584}$

Consubstanciar, ser a razão, a unificação de múltiplas coisas. Podemos entender Louis Couty por esta palavra citada no trecho acima, em que se noticiava seu falecimento em 22 de novembro de 1884. Louis Couty consubstanciou um amplo projeto de modernização do Império por múltiplas formas, pela ciência com suas ações em duas das mais destacadas instituições científcas do Segundo Reinado: Escola Politécnica, atuando na disciplina de Biologia Industrial e no Laboratório de Biologia Industrial; Museu Nacional, atuando Laboratório de Fisiologia Experimental. Subsidiou argumentos em prol da imigração europeia para o Império, sendo suas ideias

${ }^{584}$ Gazeta de Noticias, 24 nov. 1884. 
incorporadas no amplo discurso que buscou a constituição de uma classe intermediaria de pequenos proprietários, visando o branqueamento da população.

As ideias de Louis Couty ocuparam lugar em um momento de indefinição característico das décadas de 1870 e 1880, momento transitivo, que "se ainda não é o futuro, não é já o passado", dizia Machado de Assis ${ }^{585}$ que publicava seu artigo "A nova geração" na mesma edição que Couty se apresentava com seu artigo "Os estudos experimentais no Brasil". Negava-se o passado colonial, projetava-se o futuro, com as possibilidades da ciência e de seus homens, habilitados a transformar. Um país como o Brasil, com imensas possibilidades, em sua grande maioria inexplorada, cativara o forasteiro cientista. Uma carreira aberta ao seu talento colocava-se diante de Couty. Não hesitou em aceitar, sabendo que na França seus mestres o esperavam quando quisesse voltar.

Estabelecido em terras imperiais, em pouco tempo ganhava o público, estava nos debates sobre ciência e transformação do trabalho, sedimentando imagens do povo brasileiro, operando velhos problemas com novas ideias, corroborando os ideais das elites da necessidade de atrair imigrantes e branquear o país.

Como demonstramos, Couty foi um autor que escreveu muitas obras que eram sempre comentadas na imprensa, ganhado assim um amplo público leitor. Uma comunidade de leitores e comentadores de Couty se estabeleceu na Corte. Partilhavam das ideias de Couty, Silvio Romero, Alfredo Taunay, Ferreira de Araújo de um lado;

585 ASSIS, Machado. “A nova geração”. Revista Brazileira, v. 2, dez. 1879. 
de outro lado estavam aqueles que refutaram as ideias de Couty, sobretudo o movimento abolicionista, que se opôs ao que disse Couty sobre o negro e sobre a abolição. Desse modo, Couty expressou de forma bastante rica a convivência entre a luta pela emancipação da escravatura (e, posteriormente, de sua abolição) e a formulação de teses sobre a nacionalidade (ou sua impossibilidade), tributárias da associação entre raça e nação, que caracterizou largos círculos da intelectualidade brasileira do período.

A luta pela emancipação e posterior abolição assinalou a diversidade do intenso debate sobre os destinos do país. Nessa luta, Couty associou suas ideias às da necessidade de uma abolição gradual articulada com um movimento de atração de imigrantes, a fim de branquear a população e elevar o país à condição de plenamente civilizado. Com isso, suas teses sobre a inferioridade do negro, racial e individualmente, iam de encontro aos anseios de setores que viam nessa alternativa a solução para o futuro do país. A recepção e partilha de suas ideias por um setor da sociedade deu-se com esse fim.

É interessante demonstrar que a recepção das ideias de Louis Couty teve duas caracterizações. De um lado, os que deram o aceite e partilharam de sua opinião. Do outro lado, suas ideias foram refutadas. O que importa é destacar que as ideias de Louis Couty refutadas e aceitas mobilizaram os debates da década de 1880. Nesse movimento de ideias, Couty argumentava em defesa do gradualismo dos processos, suas ideias sedimentaram o projeto de uma modernização conservadora. Assim dizia ele:

O Brasil evoluirá sem lutas violentas e sem revolução, permanecendo o Brasil de sempre. Ele 
se transformará, pois estará mais povoado, mais ativo e mais forte, e dentro de quarenta anos poderá celebrar o centenário de sua Independência, mostrando ao mundo um país aberto a todas as raças, unido e patriota, para o qual os princípios de liberdade, igualdade e solidariedade não serão apenas palavras vãs sem aplicação prática. ${ }^{586}$

A permanência como transformação, era assim que pretendia Couty que fosse o futuro do país, este seria "O novo Brasil" do título do artigo. Será aberto a todas as raças, cosmopolita e moderno. Mas como demonstramos, Couty sabia a qual lugar caberia cada raça, ao negro, funções secundárias, aos brancos europeus a primazia das funções. Este homem que ia além, na sua ciência, proporcionando progresso e desenvolvimento, apresentava um projeto para a sociedade que o moderno se encontrava na permanência.

Em seus pouco mais de cinco anos no Império, Louis Couty escreveu sobre o café, o mate, a carne seca, o imigrante, o escravo; percorreu as províncias do Rio de Janeiro, de São Paulo e as do Sul, chegando às repúblicas do Rio da Prata; viajou para a França a fim de divulgar os produtos brasileiros e ampliar mercados; pesquisou sobre a fisiologia das "plantas econômicas", sobre o curare, alguns animais, projetou e dirigiu o Laboratório de Fisiologia Experimental anexo ao Museu Nacional do Rio de Janeiro; foi professor de uma disciplina nova na Escola Politécnica, a Biologia Industrial; debateu com outros cientistas e médicos, com o movimento abolicionista

586 COUTY, Louis. "O novo Brasil”. (22 maio 1884). In: O Brasil em 1884, op. cit., 1984 , p. 256. 
e teve suas ideias utilizadas para contrapor os discursos que causavam a má fama do Império no estrangeiro; figurou próximo do Imperador, o defendeu e morreu causando comoção que dimensiona o quanto a figura de Louis Couty teve uma incursão incisiva em seu contexto, sendo lida, debatida e influente. Allons, c'est bien fini ${ }^{587}$

587 "Vamos, está tudo acabado". Estas foram as últimas palavras de Louis Couty segundo Alfredo Taunay. TAUNAY, Alfredo d'E. "Louis Couty: esboço biográfico”. In: COUTY, Louis. Pequena propriedade e imigração europeia, op. cit.,1887, p. 8. 


\section{Fontes da Pesquisa}

\section{MANUSCRITAS}

Correspondências e ofícios

Arquivo da Casa Imperial do Brasil. Museu Imperial de Petrópolis.

Maço 189 - Doc. 8558. Ofício de José Agostinho Moreira Guimarães a Louis Couty.

Maço 189 - Doc. 8558. Ofício de Ladislau Netto ao Ministro da Agricultura.

Arquivo do Museu Nacional do Rio de Janeiro.

Livro de Correspondência Interna do Museu Nacional do Rio de Janeiro. 1879 a 1881

Ofício apresentando o relatório do Dr. L. Couty sobre o novo Laboratório de Fisiologia do Museu.

Ofício requisitando despacho livre na Alfândega da Corte para três caixas vindas de França pelo vapor Belgrano.

Ofício sobre troca de aparelhos e instrumentos dos Laboratórios de Biologia Industrial da Escola Politécnica e Fisiologia deste Museu. 


\section{IMPRESSAS}

\section{Escritos de Louis Couty: livros, relatórios, artigos}

COUTY, Louis. "Os estudos experimentais no Brasil". In: Revista Brazileira, ano 1, tomo 2, out./dez. 1879.

" "A Cultura do Cafeeiro na Província de São Paulo". In: Jornal do Agricultor: princípios práticos de economia rural, Rio de Janeiro, ano 1, tomo 1, jul./dez. 1879.

"Máquina de secar café". In: O Auxiliador da Indústria Nacional, Rio de Janeiro, v. 48, 1880.

A escravidão no Brasil.(1881). Tradução de Maria Helena Rouanet. Rio de Janeiro: Fundação Casa de Rui Barbosa, 1988.

"Laboratório de Physiologia Experimental". In: Anexos ao Relatório do Ministério da Agricultura. 1882.

TAUNAY, Luiz Goffredo de Escragnolle. TELLES, Augusto Carlos da Silva. Propaganda na Europa do mate, do café e da carne seca. Relatório apresentado ao ConseIheiro José Antonio Saraiva. Ministro e Secretário de Estado dos Negócios da Fazenda e interino do da Agricultura, Comércio e Obras Publicas. Anexo ao relatório do Ministério da Agricultura, 1882.

"Maquina de secar café (sistema Taunay-Telles)". In: O Auxiliador da Indústria Nacional, v. 51, 1883.

Étude de biologie industrielle sur le café: rapport adressé à M. le directeur de l'Ecole Polytechnnique. Rio de Janeiro: Imprimerie du Messager du Brésil, 1883. 
. O Brasil em 1884: esboços sociológicos. Tradução de Ligia Vassalo. Rio de Janeiro: Fundação Casa de Rui Barbosa; Brasilia: Senado Federal, 1884.

Pequena propriedade e Immigração Europeia. Obra póstuma anotada e precedida de uma introdução biográfica por Alfredo d'E. Taunay. Rio de Janeiro: Imprensa Nacional, 1887.

\section{Relatórios ministeriais e anexos}

Arquivo digital: Center for research libraries - University of Chicago. Disponivel em: <www.-apps.crl.edu/brazil/ ministerial $>$.

Ministério do Império. Relatório apresentado a Assembleia Geral Legislativa na $2^{\text {a }}$ Sessão da $16^{\text {a }}$ Legislatura, 1877.

Relatório Apresentado à Assembleia Geral Legislativa. Rio de Janeiro: Typographia Nacional, 1882.

Ministério da Agricultura. Relatório apresentado a Assembleia Geral Legislativa $3^{\text {a }}$ sessão da $17^{\text {a }}$ Legislatura, 1879.

Relatório apresentado à Assembleia Geral Legislativa na $1^{\text {a }}$ Sessão a $18^{\text {a }}$ Legislatura, 1881.

Relatório apresentado à Assembleia Geral na $2^{\text {a }}$ Sessão da $18^{\mathrm{a}}$ Legislatura, 1881.

Relatório apresentado à Assembleia Geral na $4^{\mathrm{a}}$ Sessão da $18^{\mathrm{a}}$ Legislatura, 1883.

NETTO, Ladislau. "Relatório Museu Nacional”. In: Anexos ao Relatório Ministério da Agricultura. Apresentado à Assembleia Geral Legislativa $3^{\text {a }}$ sessão da $17^{\text {a }}$ Legislatura, 1879.

"Relatório do Museu Nacional". In: Anexos ao 
Relatório do Ministério da Agricultura. Apresentado à Assembleia Geral Legislativa na $1^{\text {a }}$ Sessão da $18^{a}$ Legislatura, 1881 .

\section{Periódicos}

Biblioteca Nacional - Hemeroteca digital. Disponível em: $<$ www.hemerotecadigital.bn.br $>$.

\section{Periódicos Especializados}

A Immigração. Boletim, n. 10, ano 2, abr. 1885.

. Boletim, n. 11, ano 2, maio/jun. 1885.

. Boletim, n. 18, ano 3, fev. 1886.

Boletim, n. 33, ano 4, jun. 1887.

. Boletim, n. 53, ano 6, jan. 1889.

Gazeta Médica da Bahia. "Biografia: L. Couty julgado pelo professor Gorceix”, série 3, v. 2, 1884-1885.

Jornal do Agricultor, ano 3, tomo 5, 1881.

., ano 4, tomo 7, 1882.

., ano 5, tomo 9, 1883.

, ano 8, tomo 16, 1887.

O auxiliador, n. 5, Rio de Janeiro, 1879.

O auxiliador, v. 52, Rio de Janeiro, 1884.

\section{Jornais de grande circulação}

A data específica do jornal encontra-se nas citações em pé de página. 
Correio Paulistano

Gazeta de Notícias

Gazeta da Tarde

Jornal do Commercio

Jornal do Recife

O Abolicionismo

O Apostolo

O Liberal do Pará

O Paranaense

O Monitor

Província do Paraná

Publicador Maranhense

\section{OUTRAS FONTES:}

Livros, relatórios e artigos da época

ASSIS, Machado. "A nova geração". Revista Brazileira, v. 2, dez. 1879.

O alienista. Introdução: GLEDSON, John; Notas: GUIMARÃES. São Paulo: Penguin Classics Companhia das Letras, 2014.

DAVATZ, Thomas. Memórias de um colono no Brasil. Belo Horizonte: Itatiaia; São Paulo: Edusp, 1980. 
GOELDI, Emílio. Relatório sobre a moléstia do cafeeiro na província do Rio de Janeiro. Reeditado por Romero Marinho de Moura. Recife: UFRPE; Fadurpe, 1998. (A primeira edição é de 1887).

JOBERT, Clement. Sur une maladie du caféier au Brésil. 1878.

LAERNE, Van Delden. Le Brésil et Java: rapport sur La culture du café em amérique, asie e afrique. Paris: Challamel Ainé, 1885.

NABUCO, Joaquim. O abolicionismo. Rio de Janeiro: Nova Fronteira; São Paulo: Publifolha, 2000.

ROHAN, Henrique de Beaurepaire. "O futuro da grande lavoura e da grande propriedade no Brasil”. Memória apresentada ao Ministério da Agricultura, Comércio e Obras Públicas. In: Anais do Congresso Agrícola do Rio de Janeiro, 1878. Introdução e notas de José Murilo de Carvalho. Fundação Casa de Rui Barbosa. Edição fac-similar, 1988, p. 245.

ROMERO, Sílvio. "Introdução à história da literatura brasileira”. In: Revista Brazileira, tomo 9, set. 1881.

SCHOELCHER, Victor. "Discurso do Sr. Schoelcher". Anexo. In: COUTY, Louis. A escravidão no Brasil. Tradução de Maria Helena Rouanet. Rio de Janeiro: Fundação Casa de Rui Barbosa, 1988, p. 114-115.

TAUNAY, Alfredo d'E. "Louis Couty: esboço biográfico". In: COUTY, Louis. Pequena propriedade e imigração europeia. Obra póstuma anotada e precedida de uma introdução biográfica por Alfredo d’E. Taunay. Rio de Janeiro: Imprensa Nacional, 1887.

TAUNAY, Carlos Augusto. Manual do agricultor brasileiro. Organização de MARQUESE, Rafael Bivar. São Paulo: Companhia das Letras. 2001. 
TOCQUEVILLE, Alexis de. A emancipação dos escravos. Tradução de Fany Goldfarb. Campinas: Papirus, 1994.

WERNECK, Luiz Peixoto de Lacerda. Ideias sobre a colonização precedidas de uma sucinta exposição dos principios gerais que regem a população. Rio de Janeiro: Typographia Universal Laemert, 1855.

\section{Bibliografia}

ALONSO, Angela. "Crítica e contestação: o movimento reformista da geração 1870”. Revista Brasileira de Ciências Sociais, v. 15, n. 44, 2000.

ANDRADE, André Luís Alípio de. Variações sobre um tema: a Sociedade Auxiliadora da Indústria Nacional e o debate sobre o fim do tráfico. Dissertação (Mestrado em Economia) - IE/Unicamp, 2002.

AZEVEDO, Célia Maria Marinho de. Onda Negra, Medo Branco: o negro no imaginário das elites - século XIX. 3. ed. São Paulo: Annablume, 2008.

BARBOSA, Alexandre de Freitas. A formação do mercado de trabalho no Brasil. São Paulo: Alameda, 2008.

BARBUY, Heloisa. "O Brasil vai a Paris em 1889: um lugar na Exposição Universal”. Anais do Museu Paulista, São Paulo, n. 4, 1996.

BARROS, José D’Assunção. "História das ideias - em torno de um domínio historiográfico”. Locus: Revista de história, Juiz de Fora, v. 13, n. 1, 2007.

BASTOS, Elide. RIDENTI, Marcelo; ROLLAND, Denis (Orgs.). Intelectuais: sociedade e política, Brasil-França. São Paulo: Cortez, 2003. 
Beiguelman, Paula. A Formação do Povo no Complexo Cafeeiro: Aspectos Políticos. 2. ed. São Paulo: Biblioteca Pioneira de Ciências Sociais, 1978.

BERMAN, Marshall. Tudo o que é sólido desmancha no ar: a aventura da modernidade. Tradução de Carlos Felipe Moisés; Ana Maria Ioriatti. São Paulo: Companhia das Letras, 2013.

BOURDIEU, Pierre. Os usos sociais da ciência: por uma sociologia clínica do campo científico. Tradução de Denice Barbara Catani. São Paulo: UNESP, 2004.

CARDOSO, Ciro Flamarion; VAINFAS, Ronaldo, (Orgs.). Domínios da história: ensaios de teoria e metodologia. Rio de Janeiro: Campus, 1997.

. "História do Poder, História Política". In: Estudos Ibero-Americanos, PUCRS, v. 23, n. 1, jun. 1997.

CARULA, Karoline. A tribuna da ciência: as Conferências Populares da Glória e as discussões do darwinismo na imprensa carioca (1873-1880). São Paulo: Annablume; FAPESP, 2009.

Darwinismo, raça e gênero: conferências e cursos públicos no Rio de Janeiro (1870 - 1889). São Paulo: Tese (Doutorado em História Social) - Departamento de História/FFLCH USP, São Paulo, 2012.

CARVALHO, José Murilo de. A construção da ordem: a elite política imperial. Teatro de sombras: a política imperial. 6. ed. Rio de Janeiro: Civilização Brasileira, 2011.

Os Bestializados: O Rio de Janeiro e a República que não foi. 3. ed. São Paulo: Cia. Das Letras, 2006. 
. "Os três povos da República". In: Revista USP, São Paulo, n. 59, 2003.

CARVALHO, Maria Alice Rezende de. O quinto século: André Rebouças e a construção do Brasil. Rio de Janeiro: Revan, 1998.

COELHO, Edmundo Campos. As profissões imperiais: medicina, engenharia e advocacia no Rio de Janeiro (18221930). Rio de Janeiro: Record, 1999.

CONRAD, R. C., Os últimos anos da escravatura no Brasil, 1850-1888. Rio de Janeiro - Brasília: Civilização Brasileira. INL, 1977.

COSTA, Emilia Viotti. Da Senzala à Colônia. 2. ed. São Paulo: Ciências Humanas LTDA, 1982.

COSTA, Wilma Peres. A Espada de Dâmocles: o Exército, a Guerra do Paraguai e a Crise do Império. São Paulo: Hucitec/Unicamp, 1996.

"A questão fiscal na transformação republicanacontinuidade e descontinuidade". In: Revista Economia e Sociedade, n. 10, jun. 1998.

"Narrativas de viagem no Brasil do Século XIX: formação do estado e trajetória intelectual". In: Intelectuais e Estado. (Org.) RIDENTI, Marcelo; BASTOS, Elide Rugai; ROLLAND, Denis. Belo Horizonte: UFMG, 2006.

DALE, Tomich. "Pensando o 'impensável': Victor Schoelcher e o Haiti”. In: Mana; v. 15, n. 1, Rio de Janeiro, abr. 2009.

DOMINGUES, Heloisa M. Bertol. "As ciências naturais e a construção da nação brasileira”. In: Revista de História, $2^{\circ}$ sem., n. 135, 1996. 
DOSSE, François. O Desafio Biográfico. Tradução de Gilson C. Cardoso de Souza. São Paulo: EDUSP, 2009.

EISENBERG, Peter L. Homens Esquecidos: escravos e trabalhadores livres no Brasil, séculos XVIII e XIX. $1^{\text {a }}$ ed. Campinas: Unicamp, 1989.

FALCON, Francisco. "História das Ideias". In: Dominios da História: Ensaios de teoria e metodologia. (Org.). CARDOSO, Ciro Flamarion; VAINFAS, Ronaldo. Rio de Janeiro: Campus, 1997.

"O povo brasileiro: ensaio historiográfico". In: Revista USP, São Paulo, n. 46, 2000.

FIGUEIRÔA, Silvia Fernanda de Mendonça. "Ciência e tecnologia no Brasil Imperial: Guilherme Schüch, Barão de Capanema (1824-1908)". In: Varia História, v. 21, n. 34. Belo Horizonte, MG, 2005.

FRANCO, Maria Sylvia de Carvalho. Homens Livres na Ordem Escravocrata. São Paulo: Alfa-Ômega, 1979.

GEBARA, Ademir. O Mercado de Trabalho Livre no Brasil (1871-1888). São Paulo: Brasiliense, 1986.

GOMES, Ana Carolina Vimieiro. Uma ciência moderna e imperial: a fisiologia brasileira no final do século XIX (1880-1889). Belo Horizonte, MG: Fino traço; Campina Grande, PB: EDUEPB; Rio de Janeiro: FIOCRUZ, 2013.

GONÇALVES, Paulo César. Migração e mão de obra: retirantes cearenses na economia cafeeira do centro-sul (1877-1901). São Paulo: Humanitas, 2006.

Mercadores de Braço: riqueza e acumulação na organização da emigração europeia para o novo mundo. São Paulo: Alameda, 2012. 
GOULD, Stephen Jay. A falsa medida do homem. Tradução: Valter Lellis Siqueira. 3. ed. São Paulo: Martins Fontes, 2014.

GUALTIERI, Regina Cândido Ellero. Evolucionismo no Brasil: ciência e educação nos museus (1870-1915). São Paulo: Livraria da Física, 2008.

HOBSBAWM, Eric. A era do capital (1848-1875). Rio de Janeiro: Paz \& Terra, 2002.

HALL. Michael M, "Reformadores de classe média no Império brasileiro: a Sociedade Central de Imigração”. Revista de História, São Paulo, ano 27, v. 53, 1976.

HOLANDA, Sergio Buarque de. "Introdução”. In: DAVATZ, Thomas. Memórias de um colono no Brasil. Belo Horizonte: Itatiaia; São Paulo: Edusp, 1980.

Raizes do Brasil. São Paulo: Companhia das Letras, 2002.

Do Império à República. H. G. C. B. Tomo 2, v. 7. 8. ed. Rio de Janeiro: Bertrand Brasil, 2008.

HOLLOWAY, Thomas H. Imigrantes para o café: café e sociedade em São Paulo, 1886-1934. Tradução de Eglê Malheiros. Rio de Janeiro: Paz e Terra, 1984.

KOWARICK, Lúcio. Trabalho e Vadiagem: a origem do trabalho livre no Brasil. 2. ed. Rio de Janeiro: Paz e Terra, 1994.

LAMOUNIER, Maria Lúcia. Da escravidão ao trabalho livre: a lei de locação de serviços de 1879. Campinas: Papirus, 1988.

LOPES, Maria Margaret. O Brasil descobre a pesquisa cientifica: os museus e as ciências naturais no século XIX. São Paulo: Aderaldo \& Rothschild; Brasília: Unb, 2009. 
MAIO, Marcos Chor; SANTOS, Ricardo Ventura. Raça como questão: história, ciência e identidades no Brasil. Rio de Janeiro: FIOCRUZ, 2010.

MARQUESE, Rafael Bivar; TOMICH, Dale. "O Vale do Paraíba escravista e a formação do mercado mundial de café no século XIX”. In: Keila Grinberg; Ricardo Salles. O Império do Brasil (1808-1889). Rio de Janeiro: Civilização Brasileira, 2009, v. 2, p. 339-383.

MARSON, Isabel Andrade. "Trabalho livre e progresso". Revista Brasileira de História, São Paulo, n. 7, 1974.

MARTINS, José de Souza. O Cativeiro da Terra. 7. ed. São Paulo: Hucitec, 1998.

MELLO, Evaldo Cabral de. O Norte Agrário e o Império 1871-1889. 2. ed. Rio de Janeiro: Topbooks, 1999.

MUNANGA, Kabengele. Uma abordagem conceitual das noções de raça, racismo, identidade e etnia. Palestra realizada no $3^{\circ}$ Seminário Nacional de Relações Racial e Educação - PENESB, 05/11/2003. Disponivel em: < https://www. ufmg.br/inclusaosocial/?p = 59 > . Acesso: 18 ago. 2014 .

PETRONE, Tereza Schorer. "Imigração Assalariada”. In: O Brasil Monárquico: reações e transações. H.G.C.B. (dir.) Sergio Buarque de Holanda, tomo 2, v. 5, 8. ed. Rio de Janeiro: Bertrand Brasil, 2008, p. 323-349.

PINTO, Virgilio Noya. "Balanço das transformações econômicas no século XIX”. In: MOTA, Carlos Guilherme. (Org.) Brasil em perspectiva. 14. ed. São Paulo. Difel, 1984.

POCOCK, John A. G. Linguagens do ideário político. São Paulo: Edusp, 2003. 
PRATT, Mary Louise. Os olhos do império: relatos de viagem e transculturação. Tradução de Jézio Hernani Bonfim Gutierre. Bauru: Edusc, 1999.

RÉMOND, René. Por uma história politica. Tradução de Dora Rocha. 2. ed. Rio de Janeiro: FGV, 2003.

RIBEIRO, Luiz Cláudio M. "A invenção como ofício: as máquinas de preparo e benefício do café no século XIX". Anais do Museu Paulista, São Paulo, v. 14, n. 1, 2006.

ROCHA, Antônio Penalves. A economia politica na sociedade escravista. São Paulo: Hucitec, 1996.

ROSANVAlLON, Pierre. Por uma história do politico. São Paulo: Alameda, 2010.

SÁ, Magali Romero. "O botânico e o mecenas: João Barbosa Rodrigues e a ciência no Brasil na segunda metade do século XIX". In: História, Ciências, Saúde - Manguinhos, v. 8 (suplemento), p. 899-924, 2001.

SÁ, Magali Romero. "Do veneno ao antídoto: Barbosa Rodrigues e os estudos e controvérsias científicas sobre o curare”. In: Revista Brasileira de História da Ciência, Rio de Janeiro, v. 5, suplemento, 2012.

SALLES, Ricardo. "O Império do Brasil no contexto do século XIX. Escravidão nacional, classe senhorial e intelectuais na formação do Estado”. Revista Almanack, Guarulhos-SP, 2012, p. 1-61.

SANTOS, Claudia. Narrativas de viagem e a escrita da história: os franceses no processo abolicionista brasileiro (1850-1899). Rio de Janeiro: 7 Letras, 2013. 
SANTOS, Gislene Ap. dos. A Invenção do Ser Negro: um percurso das ideias que naturalizaram a inferioridade dos negros. São Paulo - Rio de Janeiro: Educ-FAPESP-Pallas, 2002.

SCHWARCZ, Lilia Moritz. O Espetáculo das Raças: cientistas, instituições e questão racial no Brasil 1870-1930. São Paulo: Companhia das Letras, 2008.

"Previsões são sempre traiçoeiras: João Baptista de Lacerda e seu Brasil branco”. História, Ciências, Saúde - Manguinhos, Rio de Janeiro, v. 18, n. 1, 2011.

; DANTAS, Regina. "O museu do Imperador: quando colecionar é representar a nação”. In: Revista do IEB, n. 46, p. 123-164, 2008.

As barbas do Imperador. São Paulo: Companhia das Letras, 1999.

SCHWARZ, Roberto. Um mestre na periferia do capitalismo. 4. ed. São Paulo: Ed. 34, 2006.

Ao vencedor as batatas. São Paulo: Duas Cidades, 1977.

SILVA, Ligia Osório. Terras devolutas e latifúndio: efeitos da lei de 1850. 2. ed. Campinas: Unicamp, 2008.

"Propaganda e Realidade: a imagem do Império do Brasil nas publicações francesas do século XIX". In: Revista Theomai, Argentina, Universidade Nacional de Quilmes, n. 3, 2001.

SILVA, Sergio. Expansão cafeeira e as origens da indústria no Brasil. São Paulo: Alfa-Omega, 1980. 
SIRINELLI, Jean-François. "Os Intelectuais". In: Por uma história Politica. RÉMOND, René (Org.). 2. ed. Tradução de Dora Rocha. Rio de Janeiro: FGV, 2003.

SKINNER, Quentin. Hobbes e a liberdade republicana. Tradução de Modesto Florenzano. São Paulo: UNESP, 2010.

SODRÉ, Nelson Werneck. História da imprensa no Brasil. 3. ed. São Paulo: Martins Fontes, 1983.

STAROBINSKI, Jean. As máscaras da civilização. Tradução de Maria Lucia Machado. São Paulo: Companhia das Letras, 2001 .

STEIN, Stanley J. Vassouras: um município brasileiro do café 1850-1900. Rio de Janeiro: Nova Fronteira, 1990.

STOLCKE, Verena; HALL, Michael M., "Introdução do trabalho livre nas fazendas de café de São Paulo”. In: Revista Brasileira de História, n. 6, set. 1983.

TAUNAY, Alfredo d'E. Estrangeiros ilustres e prestimosos no Brasil (1800-1892) e outros escritos. 3. ed. São Paulo: Melhoramentos, 1932.

TOPIK, Steven. "Coffe: Biology as Destiny?" In: SILVA, Sergio; SMERECSÁNYI, Tamás. História Econômica da Primeira República. São Paulo: Hucitec -FAPESP, 1996.

TUCK, Richard. "História do Pensamento Político". In: BURKE, Peter. (Org.). A Escrita da História: novas perspectivas. Tradução de Magda Lopes. São Paulo: UNESP, 1992.

VAINFAS, Ronaldo. "Caminhos e Descaminhos da História". In: Domínios da história: ensaios de teoria e metodologia. 
CARDOSO, Ciro Flamarion; VAINFAS, Ronaldo (Orgs.). Rio de Janeiro: Campus, 1997.

VASSILIEFF, Irina. A Sociedade Central de Imigração nos fins do século XIX e a "democracia rural". Tese (Doutorado em História) - FFLCH/USP, São Paulo. 1987.

VERGARA, Moema de Rezende. "Ciência e literatura: a Revista Brasileira como espaço de vulgarização cientifica”. Sociedade e Cultura, v. 7, n. 1, 2004.

"Contexto e conceitos: história da ciência e "vulgarização científica’ no Brasil do século XIX”. In: Interciencia, v. 33, n. 5, 2008.

WEFFORT, Francisco C. Formação do Pensamento Político Brasileiro: ideias e personagens. São Paulo: Ática. 2006. 